Ritzlné Kazimir Ildikó

\title{
AZ ÁFACSALÁS ALAKULÁSA \\ MAGYARORSZÁGON 2006 ÉS 2016 KÖZÖTT
}




\title{
STATISZTIKA TANSZÉK
}

\author{
SUGÁR ANDRÁS \\ tanszékvezető, egyetemi docens
}

CC Ritzlné Kazimir Ildikó 


\section{BUDAPESTI CORVINUS EGYETEM}

\section{KÖZGAZDASÁGI ÉS GAZDASÁGINFORMATIKAI \\ DOKTORI ISKOLA}

\section{AZ ÁFACSALÁS ALAKULÁSA \\ MAGYARORSZÁGON 2006 ÉS 2016 KÖZÖTT}

DOKTORI ÉRTEKEZÉS

RITZLNÉ KAZIMIR ILDIKÓ JUDIT

BUDAPEST, 2021 


\section{Tartalomjegyzék}

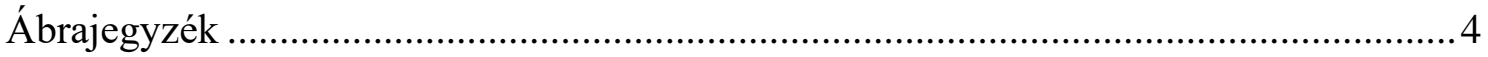

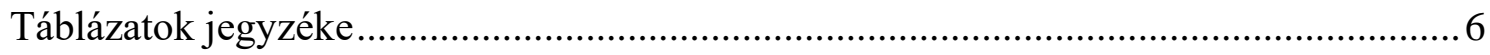

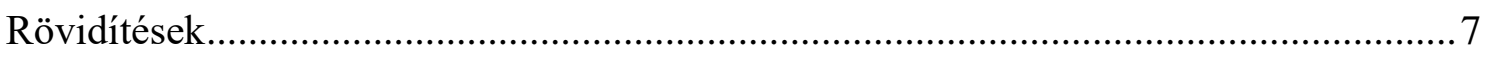

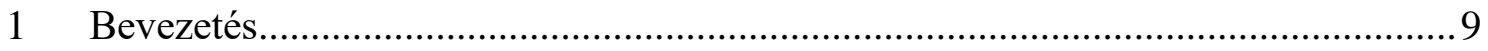

1.1. Problémafelvetés …………………………………………………………... 10

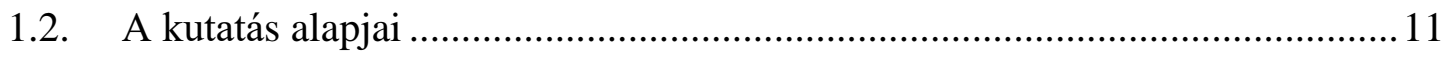

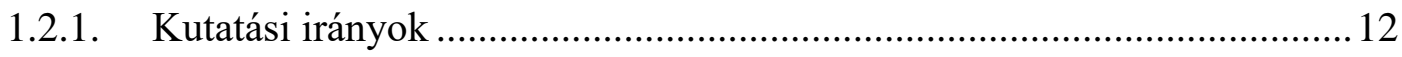

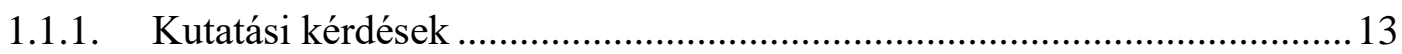

1.1.2. Kutatási megközelítés .............................................................................. 13

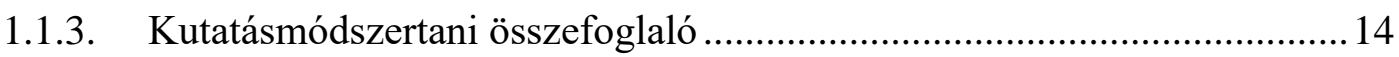

1.1.4. A kutatási eredmények összefoglalója ..................................................... 15

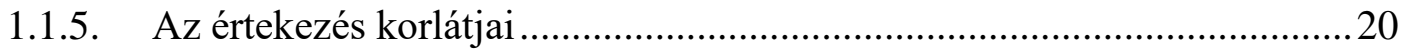

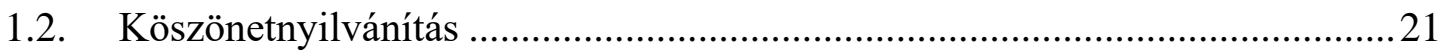

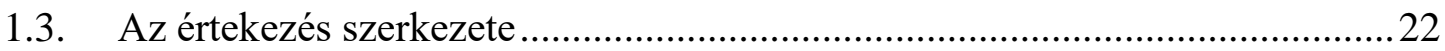

2. Az adócsalás elméletének és magyarországi történetének áttekintése.....................22

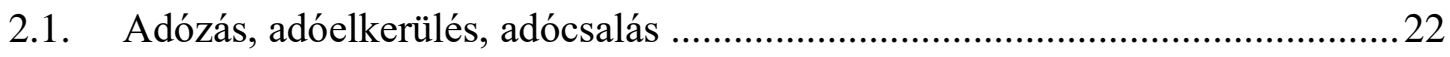

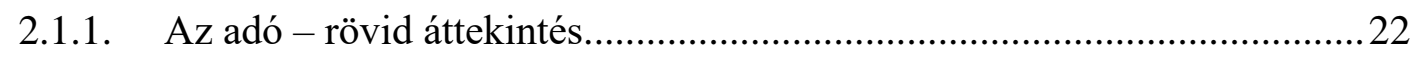

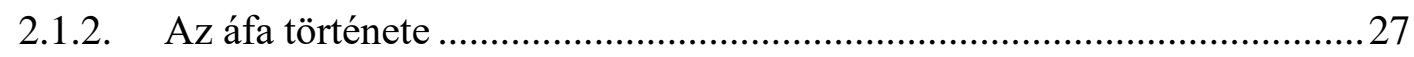

2.1.3. Adócsalás a nemzeti számlákban ..............................................................29

2.1.4. Adócsalás jogi háttere .................................................................................... 32

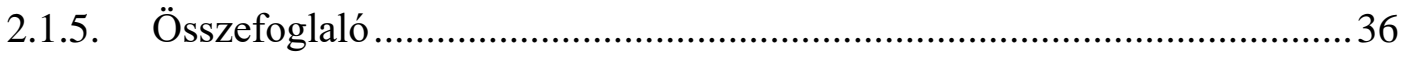

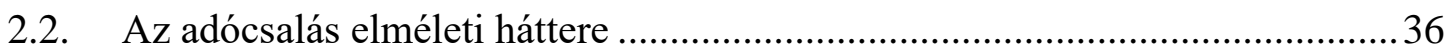

2.2.1. Az altruista és individualista magatartás modellje......................................38

2.2.2. Az adócsalás a mikroökonómia szempontjából .......................................42 


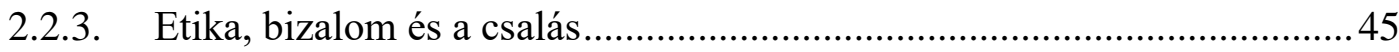

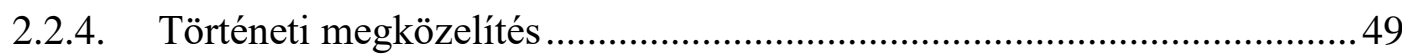

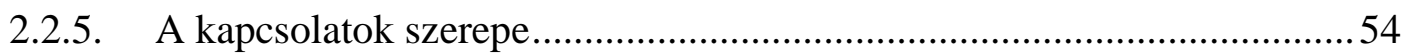

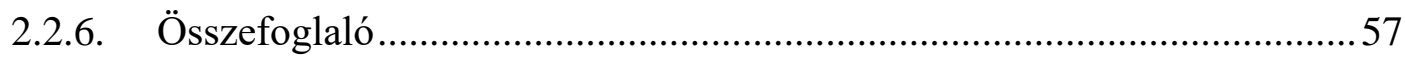

2.3. A nem megfigyelt gazdaság alakulása Magyarországon ................................58

2.3.1. Nem megfigyelt gazdaság a szocializmusban......................................59

2.3.2. A rendszerváltást követő időszak........................................................ 68

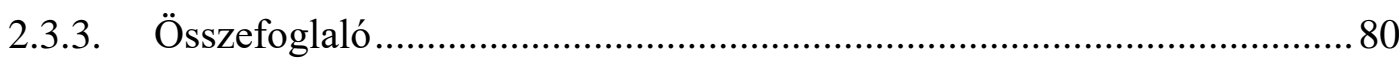

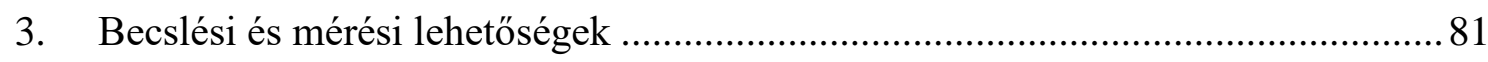

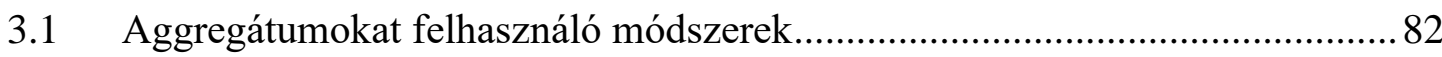

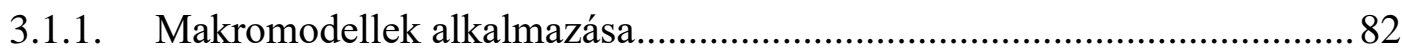

3.1.2. A nem megfigyelt gazdaság, mint látens változó ................................. 86

3.2. Input-output struktúrákon alapuló módszerek, normák alkalmazása, alulról

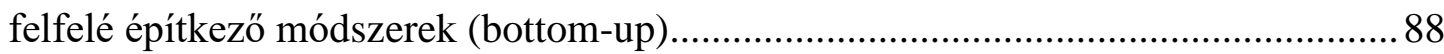

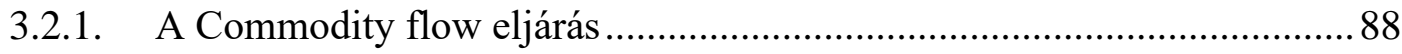

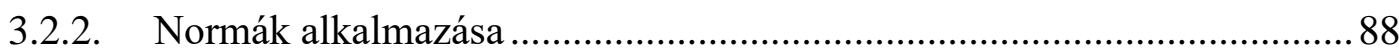

3.2.3. Bottom-up (alulról felfelé építkező) módszerek ................................... 89

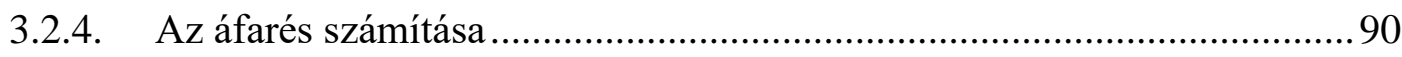

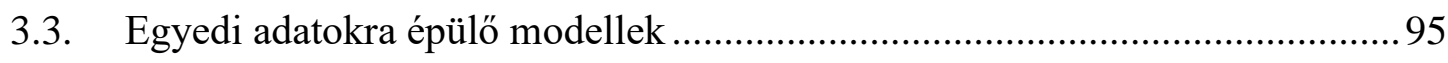

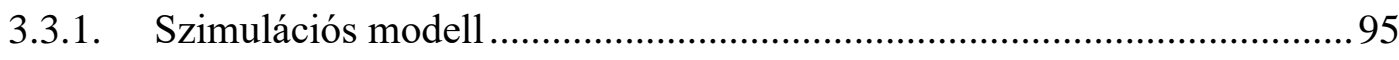

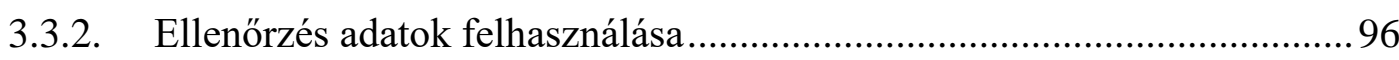

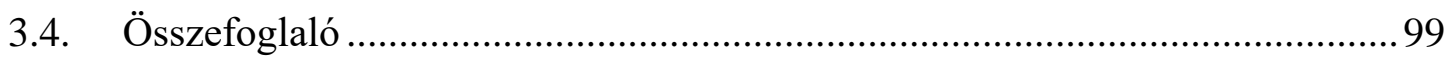

4. Az áfacsalás számszerüsítése, az eredmények elemzése .................................... 99

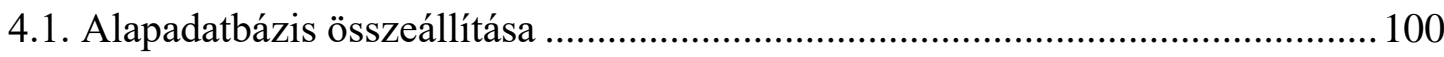

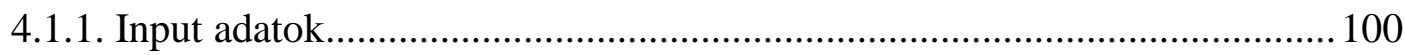

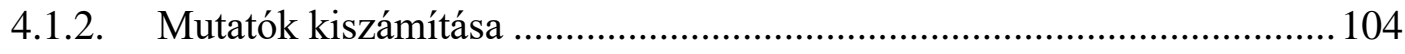

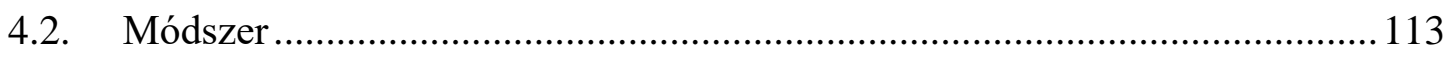




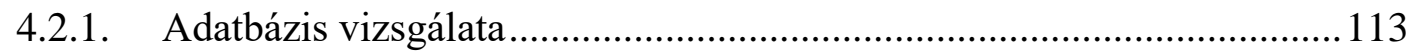

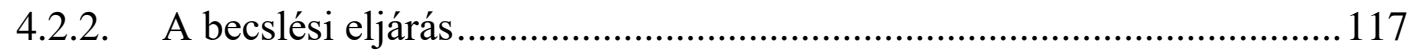

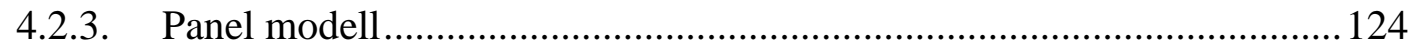

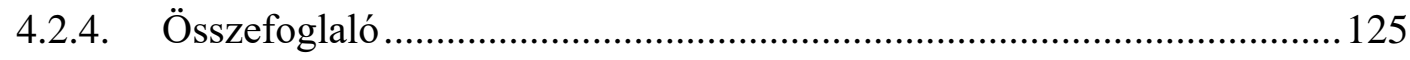

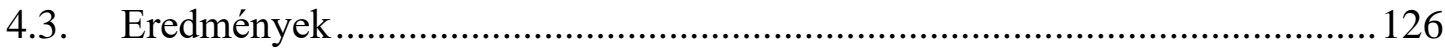

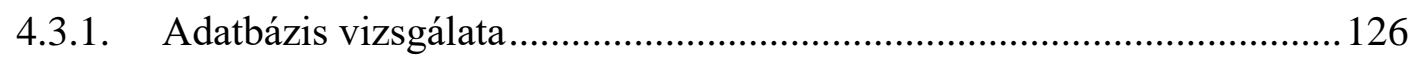

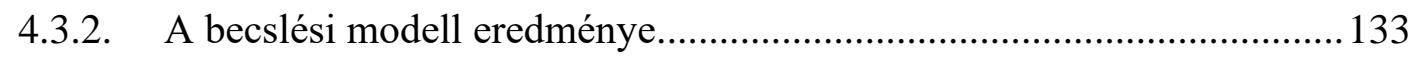

5. Az eredmények implementálása és a további kutatási lehetőségek ..................... 145

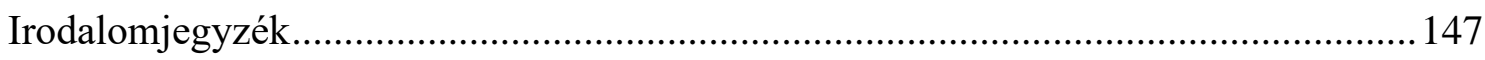

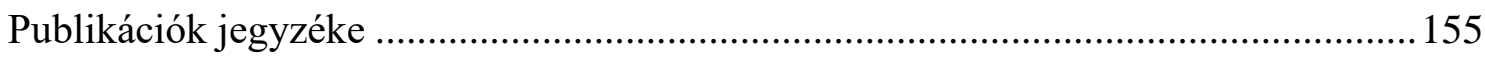

A témakörrel kapcsolatos saját (ill. társszerzős) publikációk jegyzéke .................... 155

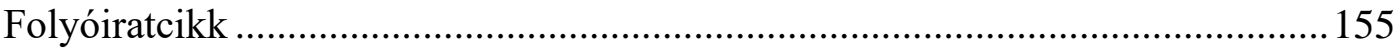

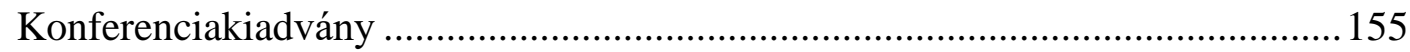

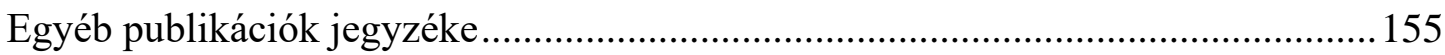

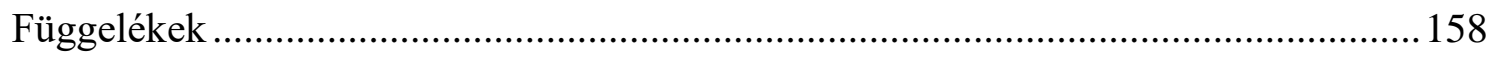




\section{Ábrajegyzék}

1. ábra: A primer kutatás két pillérének kapesolata ............................................... 14

2. ábra: A kormányzat bevételeinek csoportosítása .................................................. 23

3. ábra: Az adók csoportosításának fontosabb szempontjai ..................................24

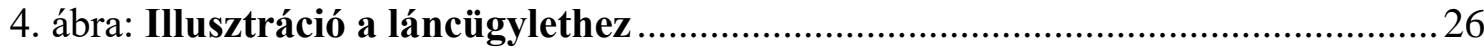

5. ábra: Az áfa bevételek és az áfa bevétel arányának alakulása az összes adóbevételen belül 1995 és 2018 között Magyarországon ......................................2 27

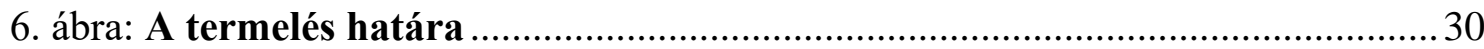

7. ábra: A proszociális tevékenység kialakulására ható tényezők egyszerüsített

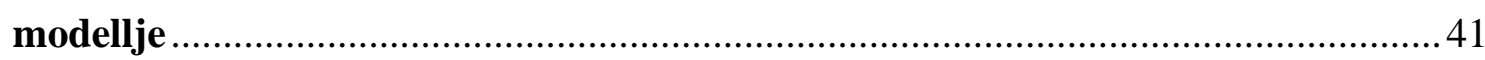

8. ábra: A kilátáselmélet szerint a csalást befolyásoló tényezők ..............................48

9. ábra: A GDP, a háztartások tényleges fogyasztásának volumenindexe, és a

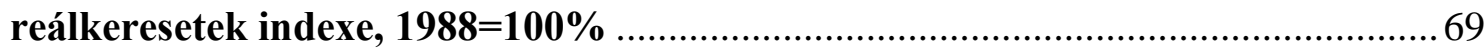

10. ábra: Az export és az import GDP-hez viszonyított aránya, \% ..........................70

11. ábra: A háztartások tényleges fogyasztási kiadása és a bruttó állóeszköz felhalmozás 2005. évi áron.

12. ábra: A magánszektor súlyának és a nem megfigyelt gazdaság arányának

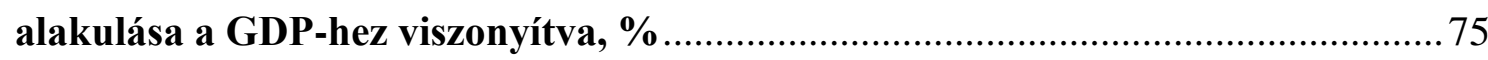

13. ábra: A rejtett gazdaság (shadow economy) GDP-hez viszonyított arányának alakulása Schneider becslése alapján, \% .87

14. ábra: Az áfarés alakulása az Európai Bizottság becslés alapján, a teoretikus nettó áfa százalékában. .94

15. ábra: Az áfarés 2016-ban az Európai Unió tagállamaiban (\%). .94

16. ábra: Az elemzésbe bevont vállalkozások számának alakulása és megoszlása nemzetgazdasági ágak szerint $(\mathrm{db})$. 104

17. ábra: Az ellenőrzött vállalkozások számának alakulása és megoszlása nemzetgazdasági ágak szerint $(\mathrm{db})$. 106

18. ábra: Az ellenőrzések során áfacsalónak bizonyult vállalkozások számának alakulása és megoszlása nemzetgazdasági ágak szerint (db) 107

19. ábra: Az ellenőrzésre kiválasztott szervezetek aránya az egyes adózási évekre nemzetgazdasági áganként, \% 108 20. ábra: Az áfacsaló vállalkozások ellenőrzött szervezetekhez viszonyított aránya 
21. ábra: Az elemzéshez alkalmazott régiós besorolás

22. ábra: A gépi tanulásos eljárások csoportosítása 118

23. ábra: A kNN módszer müködése

24. ábra: Példa egy kétszintü neurális hálózat felépítésére

25. ábra: Az előzetes felszámított áfa (millió $\mathrm{Ft}$ ) relatív gyakorisága a teljes sokaságban és az ellenőrzési adatbázisban 2012-re (\%).

26. ábra: A fizetendő áfa (millió $\mathbf{F t )}$ relatív gyakorisága a teljes sokaságban és az ellenőrzési adatbázisban 2012-re (\%)

27. ábra: Az ellenőrzésre kiválasztott szervezetek aránya az összes szervezethez viszonyítva, \%

28. ábra: Az ellenőrzési mintában lévő vállalkozásokra becsült be nem fizetett áfa megoszlása. 134

29. ábra: A becsült áfacsalás alakulása és nemzetgazdasági ágak szerinti megoszlása, $2006=100 \%$ 135

30. ábra: Az áfarés alakulása és a becslési eredmény, \% 136

31. ábra: A becsült megyei áfarés alapján meghatározott rangsor, 2006 (1=legalacsonyabb érték). 138

32. ábra: A becsült megyei áfarés alapján meghatározott rangsor, 2012 (1=legalacsonyabb érték). 139

33. ábra: A becsült megyei áfarés alapján meghatározott rangsor, 2016 (1=legalacsonyabb érték). 140

34. ábra: Az alapmodell illesztésének eredménye 143

35. ábra: A továbbfejlesztett modell diagnosztikái 144 


\section{Táblázatok jegyzéke}

1. táblázat: A nem megfigyelt tevékenységek csoportosítása 31

2. táblázat: A jelenleg hatályos és az ezt megelőző állapot szerinti értékhatárok a

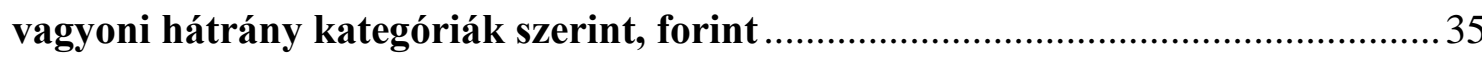

3. táblázat: Az alkalmazott létszámkategóriák ...................................................... 111

4. táblázat: A változók közti kapcsolat mérésének lehetőségei ............................... 115

5. táblázat: A fizetendő és előzetesen felszámított áfa fontosabb mutatói, 2012 .... 129

6. táblázat: Az ellenőrzött és nem ellenőrzött vállalkozások száma régiók és

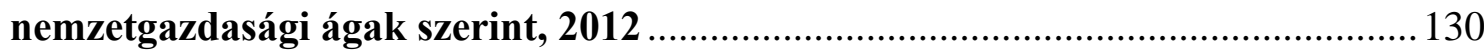

7. táblázat: Az outlierek száma és aránya az ellenőrzési állományon belül............ 133

8. táblázat: Az egy fő́re jutó GDP 2005. évi áron, mFt ........................................... 142

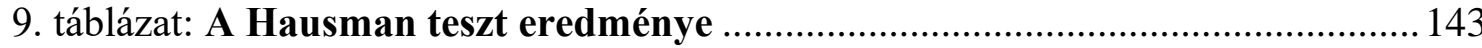




\section{Rövidítések}

ANOVA Variancia analízis, Analysis of Variance

áfa Általános forgalmi adó

Btk. Büntető Törvénykönyv

CPA Statistical classification of products by activity

EKÁER Elektronikus Közúti Áruforgalom Ellenőrző Rendszer

ESA European System of National Accounts

EU Európai Unió

EVA Egyszerüsített Vállalkozói Adó

GDP Gross Domestic Product, Bruttó Hazai Termék

GFO Gazdálkodási forma

GNI Gross National Income, Bruttó Nemzeti Jövedelem

GSzR Gazdálkodó Szervezetek Regisztere

GVA Gross Value Added, Bruttó Hozzáadott Érték

KATA Kisadózó vállalkozások tételes adója

KGST Kölcsönös Gazdasági Segítségnyújtás Tanácsa

KIVA Kisvállalati adó

kNN k nearest neighbor method, k legközelebbi szomszéd eljárás

KSH Központi Statisztikai Hivatal

MTIC Missing Trader Intry-Community fraud

NACE Nomenclature statistique des activités économiques dans la Communauté européenne, Statistical classifiation of economic activities in the European Community

NAV Nemzeti Adó- és Vámhivatal

OECD Organisation for Economic Co-operation and Development 
OSAP Országos Statisztikai Adatgyüjtési Program

NAV Nemzeti Adó- és Vámhivatala

NUTS Nomenclature of Territorial Units for Statistics, Statisztikai Célú Területi Egységek Nomenklatúrája

TEÁOR’08 Gazdasági tevékenységek egységes ágazati osztályozási rendszere 


\section{Bevezetés}

A nem megfigyelt gazdaság minden országban jelen van. A nem megfigyelt gazdaság gyüjtőfogalom, minden olyan tevékenységet magában foglal, amelyek nem figyelhetők meg a hivatalos statisztika szokásos módszereivel.. Meghatározó része az adócsalás és az adócsalás miatt nem megfigyelt tevékenység. A dolgozat témája az adócsalással, és ezen belül is az áfacsalás becslése.

$\mathrm{Az}$ áfacsalás jelentős problémát jelent Magyarországon. Az adócsalásnak számos társadalmi következménye van, növeli az egyenlőtlenséget, csökkenti a hatékonyságot, költségvetési kockázatot okoz a bevételkiesés révén, rontja a közjavak minőségét. (Fenyvesi \& Vágány, 2020) Az áfacsalás miatt az adóbevallások és felmérésekből származó adatok hiányosak, torzítottak, a nemzetgazdasági teljesítményre vonatkozó makrostatisztikai mutatók emiatt kiegészítésre szorulnak.

Egy ország nemzetgazdasági teljesítményét a nemzeti számlák makrogazdasági statisztikai számlarendszere összesíti. A számlarendszer mutatóinak a szándékos torzítás, például adócsalás miatt nem megfigyelt gazdasági teljesítményt is konzisztensen és a jogszabályok által meghatározott bontásban (például tevékenység és intézményi szektor szerint) tartalmazni kell. (Official Journal of the European Union, 2013) Az áfacsalás becslése a nemzeti számlák szempontjából különösen fontos, hiszen hozzáadott érték jellegű adóként a csalás már a termelés szintjén torzítja a nemzeti számlák mutatóit, a GDP nagyságát is közvetlenül befolyásolja. Az így realizált be nem fizetett vagy nem jogosan visszaigényelt áfa egyrészt a termelő jövedelmeként jelenik meg, másrészt a csalás miatt nem megfigyelt termelés számottevő hozzáadott értéket jelenthet.

Mivel a nemzeti számlák rendszere konzisztens és koherens rendszer, ezért a nem megfigyelt gazdaság hatása a teljes számlarendszeren keresztül megjelenik, számos mutató alakulására hatással van. Vagyis az áfacsalás hatással van az árupiacon keresztül a jövedelmek elosztására, a felhalmozásra és a megtakarításra is.

A nem megfigyelt gazdaság elszámolásának fontosságát három indokkal szeretném hangsúlyozni. Elsőként a gazdasági tevékenységek pontos és részletes elszámolása a gazdaságpolitikusok, döntéshozók és kutatók számára elengedhetetlen. A nemzeti számlák mutatóit számos helyen használják, és sok egyéb mutató részét képezik. A mutatók teljességének érdekében ezen tevékenységek elszámolása szükséges. Második a tagállami hozzájárulások megfelelő kiszámítása. Az Európai Unió (EU) tagállami 
hozzájárulása az EU saját forrásainak legjelentősebb része, ezt a Bruttó Nemzeti Jövedelem (GNI) alapján határozzák meg. Ezért a nemzeti számlák elszámolásainak pontossága az EU kifejezett érdeke. Harmadik ok a makrostatisztikai adatok nemzetközi összehasonlíthatósága. Az azonos tartalmú nemzeti számla adatok teszik lehetővé a gazdasági teljesítmény nemzetközi összehasonlítását. A nem megfigyelt gazdaság országonként eltérő, ezért a kiigazítások beillesztése a nemzeti számlákba az összehasonlíthatóság elengedhetetlen feltétele.

Munkám során feladatom az áfacsalás miatt nem megfigyelt hozzáadott érték becslése. Több éves kutatási tapasztalatom alátámasztja, hogy a nem megfigyelt hozzáadott érték becsléséhez a részletes áfacsalás becslés rendkívül fontos. A disszertációban ismertetett kutatás reményeim szerint elősegíti az áfacsalás tendenciáinak jobb megértését elméleti és történeti kontextusban, az eredmények a nemzeti számlák összeállítása során hasznosulnak, és az áfacsalás szintjének befolyásoló tényezői és tendenciái könnyebben megérthetővé válnak Magyarországon.

\subsection{Problémafelvetés}

A kutatás az áfacsalás mértékének meghatározására irányul Magyarországon a 20062016 közötti időszakra.

Az áfacsalás becslése nagy szakmai kihívást jelent.

Az áfacsaló tevékenység legtöbbször kiegészíti a legális tevékenységet, azzal párhuzamosan müködik. Ugyanakkor a csalók érthető okokból mindent megtesznek annak érdekében, hogy a hatóságok számára hihető adóbevallásokat állítsanak elő. Mivel azonban a legális tevékenység az áfacsaló tevékenységtől nem függetleníthető, a bevallásban szereplő adatok is torzítottak lesznek, az abból számított mutatók nem felelnek meg a müködőképesség valós feltételeinek. A túlságosan magas folyó termelőfelhasználás arány, az alacsony profit, a részmunkaidős, minimálbéres foglalkoztatás (zsebbe fizetés) szintén az áfacsalás velejárója lehet.

Az áfacsalás érintheti a termelést és az erőforrások felhasználását egyaránt. A helyzetet tovább bonyolítja, hogy az áfacsalás összejátszással, vagy a kereskedelmi partner, vevő, eladó tudta nélkül is megvalósulhat. Az értékesítési láncot és a versenytársak relatív helyzetét befolyásolhatja egyes szereplök áfacsaló magatartása. 
Az áfacsalás komplexitása abban is megnyilvánul, hogy a csaló magatartás kialakulása számos különböző tényező eredője, amelyek közül a belső, kockázathoz való viszonyulás és egyéb pszichológiai tényezők mellett a külső, intézményi környezet és szokásrendszer is meghatározó.

Látható, hogy az áfacsalás összetett jelenség. Különböző ismérvek mentén csoportosíthatjuk az egyes csaló tevékenységeket, vagy akár a csalásban résztvevő gazdasági szereplőket is. A teljesség igénye nélkül csoportosítási szempont lehet a csalás típusa, például láncolatos áfacsalás, utaztatós áfacsalás; az érintett tétel, például beszerzés vagy értékesítés; az elkövetés formája, például bünszervezetben vagy anélkül elkövetett csalás.

A komplexitás és a heterogenitás ellenére makrogazdasági szempontból a be nem fizetett áfa teljes összege a lényeges. Az egyes tényezők, mint például az adózási és intézményi környezet változása, vagy a gazdasági növekedés, recesszió hatásai az áfacsalásra csak akkor vizsgálhatók, ha azonos módszertannal készült áfacsalás becslés hosszabb időszakra áll rendelkezésre. Ilyen teljes, hosszabb időszakot lefedő áfacsalás becslés eddig még nem készült a magyar gazdaságra.

Ez a becslés a nemzeti számlák összeállításához is elengedhetetlen. Az adócsalás miatt nem megfigyelt hozzáadott érték számításához szükségesek a részletes áfacsalás adatok megfelelő, homogén idősorban.

Ugyanakkor az áfacsalás jellege miatt számos módszertani probléma felmerül. A csalásfelderítés alapvetően klasszifikációs feladat. Emiatt általában valamilyen klasszifikációs eljárás használható a becslés során. Ilyenek a logisztikus regresszió, a döntési fa vagy egyéb gépi tanulásos klasszifikációs eljárások. Makrostatisztikai szempontból azonban sokkal fontosabb az, hogy mekkora a csalás nagysága, mint hogy a populációból ki tekinthető csalónak. A becslési eljárás kiválasztásánál mindezen problémákat figyelembe kell venni.

\subsection{A kutatás alapjai}

Ebben a fejezetben a kutatás egészét tekintem át. Elsőként a kutatási célokat fejtem ki, majd ezek alapján megfogalmazom a kutatási kérdéseket. Ezt követi a kutatásmódszertan ismertetése, és az eredmények összefoglalása. Végül az értekezés korlátjai hívom fel a figyelmet. 


\subsubsection{Kutatási irányok}

A kutatás célja egy konzisztens és koherens, mikroadatokra épülő modell létrehozása az áfacsalás becslésére, amely figyelembe veszi az áfacsalás jellegzetességeit, ehhez a megfelelő statisztikai módszereket használja fel, és alkalmas arra, hogy segítségével az áfacsalás számszerüsítése elvégezhető legyen a 2006-2016 közötti évekre. A kutatás további célja, hogy az áfacsalás alakulásának okaira vonjon le következtetéseket.

A kutatástól elvárt eredmények a következők:

EO1: AZ ADÓCSALÁS ELMÉLETÉNEK, MAGYARORSZÁGI TÖRTÉNETÉNEK ÖSSZEFOGLALÁSA, AZ ADÓCSALÁS HETEROGENITÁSÁNAK BEMUTATÁSA.

EO2: A RENDELKEZÉSRE ÁLLÓ BECSLÉSI MÓDSZEREK ÉRTÉKELÉSE AZ ÁFACSALÁS SZÁMSZERÜSÍTÉSÉNEK SZEMPONTJÁBÓL

EO3: MikroAdATOKAT TARTALMAZÓ ADATBÁZISOK ÖSSZEÁLlíTÁSA A 20062016 KÖZÖTTI ÉVEKRE

EO4: MEGFELELÖ BECSLÉSI MODELL FELÁLLÍTÁSA AZ ÁFACSALÁS JELLEGZETESSÉGEIT FIGYELEMBE VÉVE

EO5: A BECSLÉS VÉGREHAJTÁSA A 2006-2016-OS ÉVEKRE, AZ EREDMÉNYEK ÉRTÉKELÉSE, VALIDÁLÁSA

EO6: A GAZDASÁGI NÖVEKEDÉS ÉS A GAZDASÁGI VÁLSÁG HATÁSÁNAK KIMUTATÁSA AZ ÁFACSALÁS ALAKULÁSÁRA MAGYARORSZÁGON

A kutatás elsődleges és legfontosabb célja az, hogy számszerüsítse az áfacsalás miatt be nem fizetett áfa összegét a 2006-2016-os periódusra. A cél megvalósításához a következő részcélok tartoznak, amelyek a kutatástól elvárt eredmények hasznosításával megvalósíthatók:

RO1: MILYEN MOTIVÁCIÓK ÉS TÉNYEZŐK ÁLLNAK A SZABÁLYKERÜLŐ, ÁFACSALÓ MAGATARTÁS MÖGÖTT?

RO2: MAGYARORSZÁGON MILYEN ELÖZMÉNYE VAN A NEM MEGFIGYELT GAZDASÁGNAK, ÉS AZ MENNYIBEN MAGYARÁZZA AZ ÁFACSALÁST VISZONYLAG MAGAS SZINTJÉT? 
RO3: MILYEN MÓDON HASZNÁLHATÓK FEL A NEMZETKÖZI SZAKIRODALOMBAN BEMUTATOTT ÉS AZ NEMZETKÖZI SZERVEZETEK AJÁNLÁSAIBAN SZEREPLÖ MÓDSZEREK AZ ÁFACSALÁS BECSLÉSÉRE?

RO4: MILYEN TÉNYEZŐK BEFOLYÁSOLTÁK LEGINKÁBB AZ ELMÚLT ÉVTIZEDBEN AZ ÁFACSALÁS ALAKULÁSÁT MAGYARORSZÁGON?

\subsubsection{Kutatási kérdések}

A várt kutatási eredmények és a kapcsolódó kutatási célok tükrében a következő kutatási kérdésekre fókuszálok:

RQ1: HOGYAN BECSÜLHETŐ AZ ÁFACSALÁS AZ EGYEDI SZERVEZETEK SZINTJÉN?

RQ2: HogYAN ALAKUL AZ ÁFACSALÁS SZINTJE MAGYARORSZÁGON A 2006-2016OS ÉVEKBEN?

RQ3: HOGYAN VALIDÁLHATÓ AZ EREDMÉNY?

RQ4: KimUTATHATÓ-E A GAZDASÁGI NÖVEKEDÉS ÉS A VÁLSÁG HATÁSA AZ ÁFACSALÁS ALAKULÁSÁBAN A VIZSGÁLT IDŐSZAKBAN MAGYARORSZÁGON?

\subsubsection{Kutatási megközelítés}

A primer kutatás során alapvetően kvantitatív módszereket alkalmaztam. A kutatás célja az áfacsalás számszerüsítése, makrostatisztikák előállításának elősegítése érdekében, ezért a statisztikai elemzések, modellek és tesztek álltak rendelkezésre módszertani kínálatként a primer kutatásom végrehajtásához. A kvantitatív kutatás előnye, hogy megismételhető, eredményei általánosíthatók és kevésbé szubjektív. Ugyanakkor jelentős hátránya, hogy a motivációk a kvantitatív módszertannal nem feltárhatók. A motivációk feltárását emiatt kutatásomban a szekunder kutatás alapozta meg.

A klasszikus szakirodalmi áttekintés (szekunder kutatás) során tisztáztam a kutatási terület fogalomkészletét, áttekintettem a szabálykerülő magatartást feltáró elméleti irodalmat. Megvizsgáltam a második világháború után a nem megfigyelt gazdasági tevékenységek kialakulását, szerepét és funkcióját. Kimutattam, hogy mi vezetett a jelentős áfacsaló magatartás kialakulásához Magyarországon, és milyen intézkedéseket alkalmazott a kormányzat az áfacsalás visszaszorítására. Áttekintettem a nemzetközi irodalomban alkalmazott becslési módszereket.

A primer kutatásom két pilléren nyugszik. 
Egyrészt az egyedi, vállalkozás szintü adatbázisokon végrehajtottam az áfacsalás becslést. Az egyedi szintű adatbázist a vállalkozások éves beszámoló, áfa bevallás adataiból és egyéb a müködést jellemző kategória jellegű változóiból állítottam össze. Az egyedi becslés alkalmazhatóságát a szekunder kutatás támasztotta alá, ami meggyőző érveket sorakoztatott fel amellett, hogy a szabálykerülő magatartás történeti és elméleti okokból is számos különböző tényezőre vezethető vissza.

A második pillér az eredményekre alkalmazott panel becslést tartalmaz. A panel modell azt vizsgálja, hogy az áfacsalás alakulására kimutatható hatást gyakorol-e a gazdasági növekedés. A kutatás alapja az a kutatási eredményem, hogy az áfacsalás aránya az elméleti (teoretikus) áfa kötelezettséghez mérten 2012 után csökken. Ennek két meghatározó tényezője is lehet, ha az egyénre jellemző egyedi faktorokat állandónak tekintjük: a gazdasági növekedés és a kormányzat adócsalást csökkentő összetett, több területet érintő beavatkozásai. A két pillér kapcsolatát a következő 1 . ábra mutatja be.

\section{1. ábra: A primer kutatás két pillérének kapcsolata}

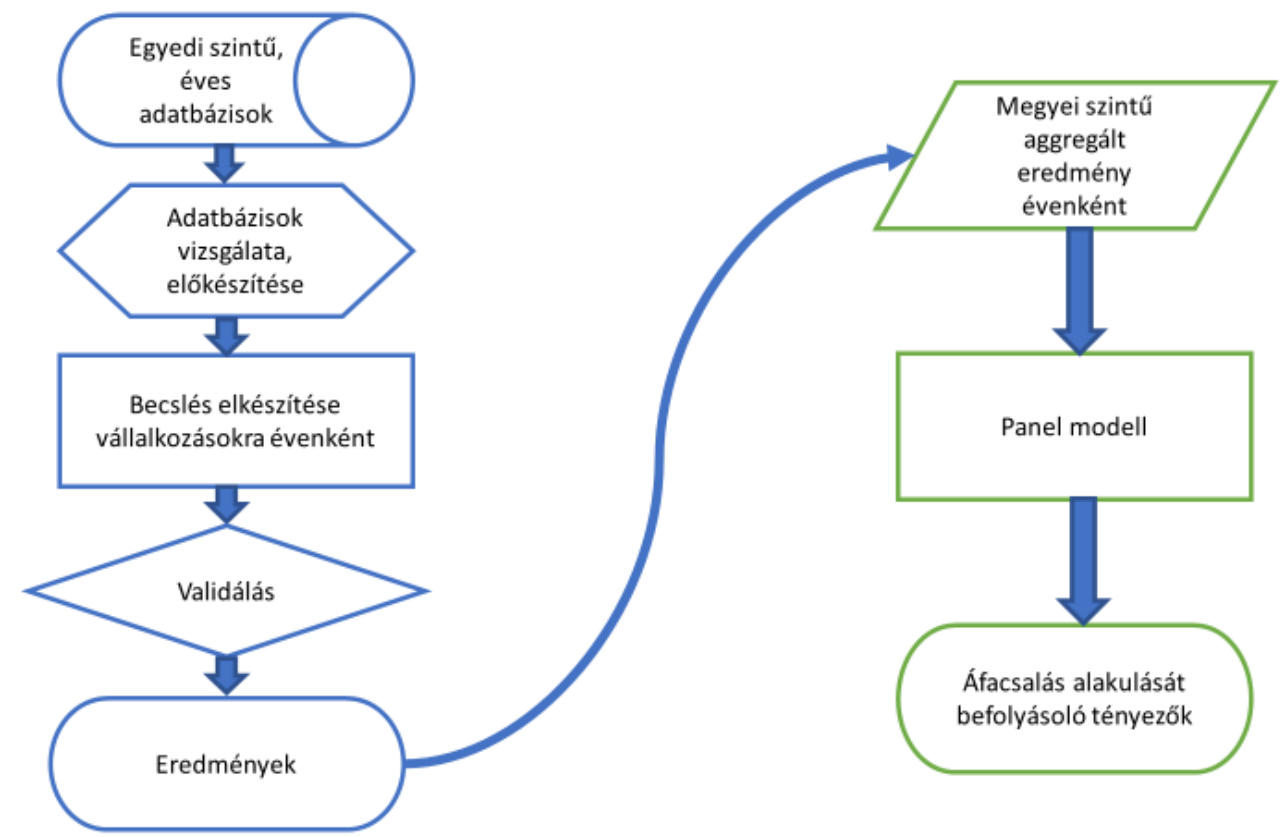

Forrás: saját szerkesztés

\subsubsection{Kutatásmódszertani összefoglaló}

Az áfacsalás számszerüsítése érdekében kidolgoztam egy egyedi adatokon alapuló becslési modellt. Majd megvizsgáltam, hogy az áfacsalás alakulását befolyásolja-e a gazdasági növekedés és a válság kialakulása, mint különleges motivációs tényező. 
A szekunder kutatás keretein belül a következő logikai láncot követtem:

- adórendszer

- áfa

- áfacsalás

- nem megfigyelt gazdaság makrogazdasági számításba vétele

- a csalás és szabályszegő magatartás magyarázata a különböző tudományterületek keretrendszerén belül

- a különböző nem megfigyelt, szabályszegő magatartásformák magyarországi alakulása

- a nem megfigyelt tevékenységek becslésének lehetőségei.

A szekunder kutatás eredménye alapján nyilvánvalóvá vált számomra, hogy az áfacsalás becslésére alkalmazott, makrostatisztikai felhasználásra alkalmas új, részletes módszertant kell kifejleszteni.

A primer kutatásban egyedi adatokon, áfaellenőrzés adatok felhasználására épülő, gépi tanulásos eljárást alkalmazó modellt dolgoztam ki. A becslést az általam alkotott modellel 2006-2016 közötti évekre elvégeztem. Az egyedi szintű eredmények kiszámítása után merült fel bennem az a kérdés, hogy az áfacsalás arányának csökkenése az elméleti áfabevételekhez képest (áfarés) milyen tényezőknek köszönhető. Hiszen amellett, hogy a kormányzat jelentős erőfeszítéseket tett az áfacsalás csökkentésére, ezekkel az intézkedésekkel egybeesett a magyar gazdaság kilábalása a 2008-as válságból, és jelentős mértékủ GDP növekedés kezdődött Magyarországon.

Ezért megyei szintre aggregált adatokra illesztett panel modellel vizsgáltam meg a gazdasági növekedés és az intézményi környezet változásának hatását.

\subsubsection{A kutatási eredmények összefoglalója}

A kutatás legfőbb célja volt, hogy a 2006-2016 évekre egységes módszertannal becsülje az áfacsalás nagyságát olyan módon, amely a makrostatisztikák készítéséhez megfelelő inputot biztosít. Emiatt elsőként az RO1 kutatási cél merült fel, mert a jelenség megértéséhez szükséges elméleti háttér feltérképezése elengedhetetlenül fontos.

Az elmélet felderítése után nyilvánvalóvá vált, hogy a hazai helyzet a szocialista gazdasági rendszer és az elhúzódó rendszerváltás miatt sajátos. A nálunk kialakuló nem megfigyelt gazdaság egyedi, nem hasonlítható a fejlett piacgazdaságokban megfigyelt 
adócsalás gyakorlathoz. Emiatt a nem megfigyelt tevékenységek alakulásának, területeinek és funkcióinak vizsgálata vált szükségessé a második világháborút követő időszaktól kezdve (RO2).

A harmadik cél, a számszerüsítési lehetőséget vizsgálata a fő célból egyenesen származtatható volt (RO3).

Végül a negyedik cél (RO4) az előző három cél eredményeit hasznosítva volt megvalósítható.

Az egyes kutatási célokhoz kötődő eredményeket a disszertáció alábbi fejezetei tartalmazzák.

RO1: MILYEN MOTIVÁCIÓK ÉS TÉNYEZŐK ÁLLNAK A SZABÁLYKERÜLÖ, ÁFACSALÓ MAGATARTÁS MÖGÖTT?

A szabálykövetés a társadalmi együttmüködés egyik formája. Az együttmüködés függ az altruista magatartástól, a normák erösségétöl, az önérdekkövetö magatartástól. A szociálpszichológia, mikroökonómia területéröl vett, a történeti, szociológiai, antropológiai és politikaitudomány területéről származó magyarázatokat ismerteti a 2.2 fejezet. A fejezetből látható, hogy a szabálykerülö, csaló magatartás mögött számos különbözö ok állhat. A magyarázatok egymást nem zárják ki, az eltérö motivációk egymás mellett müködhetnek.

RO2: MAGYARORSZÁGON MILYEN ELÖZMÉNYE VAN A NEM MEGFIGYELT GAZDASÁGNAK, ÉS AZ MENNYIBEN MAGYARÁZZA AZ ÁFACSALÁST VISZONYLAG MAGAS SZINTJÉT?

A nem megfigyelt gazdasági tevékenységek kialakulásáról a szocialista gazdasági rendszerben, az átalakulás időszakában; és a rendszerváltás utáni magatartásformákról szól a 2.3 fejezet. Magyarországon a nem megfigyelt, szabálykerülö tevékenységek a különbözö idöszakokban eltérö okokból jöttek létre, és eltérö funkciót töltöttek be. Számos esetben a szabálykerülö magatartás gazdaság müködése szempontjából hasznosnak bizonyult. Ugyanakkor a jól müködö piacgazdaság müködését ezek a tevékenységek akadályozták az EU csatlakozást követö években. 
RO3: MILYEN MÓDON HASZNÁLHATÓK FEL A NEMZETKÖZI SZAKIRODALOMBAN BEMUTATOTT ÉS AZ NEMZETKÖZI SZERVEZETEK AJÁNLÁSAIBAN SZEREPLŐ MÓDSZEREK AZ ÁFACSALÁS BECSLÉSÉRE?

A nemzetközi szervezetek osztályozási rendszerét és az általuk ajánlott becslési módszereket a 2.1.3 és a 3. fejezet tartalmazza. A 3. fejezetben a nemzetközi szakirodalomban megjelenö fontosabb becslési módszereket is ismertetem. Ezekkel kapcsolatban két fontos kritika fogalmazható meg: nem képesek a jelenség heterogenitását kezelni, és nem alkalmasak kellöen részletes becslés elöállitására. Emiatt saját modell kialakitása vált szükségessé.

RO4: MILYEN TÉNYEZÖK BEFOLYÁSOLTÁK LEGINKÁBB AZ ELMÚLT ÉVTIZEDBEN AZ ÁFACSALÁS ALAKULÁSÁT MAGYARORSZÁGON?

A becslési eljárás eredményét a 4.3 fejezet tartalmazza. A panel modell eredménye a 4.3.2.4 alfejezetben található. A beszámoló, áfa bevallás és kategória változók alapján a vizsgált időszakra becsültem az áfacsalás alakulását és homogén áfacsalás idösort állitottam elö. Ezen ki tudtam mutatni a gazdasági növekedés hatását. Eredményeim szerint az egy före jutó reál GDP emelkedésével az áfarés csökken. Továbbá ki kell emelni, hogy a válság esetében az áfarés ugrásszerüen megnö.

A kutatási célokhoz kutatási kérdéseket rendeltem hozzá. A kutatási kérdésekre a következő rövid válaszokat adtam.

\section{RQ1: HOGYAN BECSÜLHETŐ AZ ÁFACSALÁS AZ EGYEDI SZERVEZETEK SZINTJÉN?}

Megoldás: Az áfacsalás az adóellenőrzés adatok felhasználásával jól becsülhető. A becslés során figyelembe kellett venni azt, hogy a minta nem reprezentativ, és azt is, hogy az áfacsalás nem homogén magatartás. Emiatt választottam nemparaméteres gépi tanulásos eljárást, amely alkalmas többmóduszú sokaságokon végzett becslések végrehajtására is, és eloszlásfüggetlen.

RQ2: HogYAN ALAKUL AZ ÁFACSALÁS SZINTJE MAGYARORSZÁGON A 2006-2016OS ÉVEKBEN? 
Megoldás: Az áfacsalást az elméleti áfabevétel arányában kell vizsgálni. Ez az arány 2011-ig nött, 2011-ben 29\%-ot ért el a szintje. 2012-töl csökkenni kezdett az arány, 2016-ban az elméleti áfabevétel 10\%-át érte el a szintje.

\section{RQ3: HOGYAN VALIDÁLHATÓ AZ EREDMÉNY?}

Megoldás: Az áfacsalás becslést az Európai Bizottság megrendelésére készitett áfarés értékekkel validáltam. Az áfarés becslés néhány olyan tételt is tartalmaz, amit az áfacsalás becslés nem. Emiatt az áfarés általában magasabb, mint az áfacsalás becslés. Az áfacsalás és az áfarés alakulása a vizsgált idöszakban megegyezik.

RQ4: KimUTATHATÓ-E A GAZDASÁGI NÖVEKEDÉS ÉS A VÁLSÁG HATÁSA AZ ÁFACSALÁS ALAKULÁSÁBAN A VIZSGÁLT IDŐSZAKBAN MAGYARORSZÁGON?

Megoldás: A megyei szintre aggregált áfacsalás eredményekre panel modellt illesztettem. Ennek eredményeként azt kaptam, hogy az áfarés függ az egy före jutó reál GDP nagyságától, a saját korábbi időszaki értékétől és a válsággal járó bizonytalanságtól.

A kutatási célok meghatározása során figyelembe vettem, hogy az eredmények felhasználhatóak legyenek a makrostatisztikák összeállítása során. A célok meghatározásában nagy előnyt jelentett a nem megfigyelt gazdaság becslésében szerzett többéves tapasztalatom.

EO1: AZ ADÓCSALÁS ELMÉLETÉNEK, MAGYARORSZÁGI TÖRTÉNETÉNEK ÖSSZEFOGLALÁSA, AZ ADÓCSALÁS HETEROGENITÁSÁNAK BEMUTATÁSA.

Az elméleti megalapozottság és a számszerüsitési gyakorlat a nem megfigyelt gazdaság és az áfacsalás területén meglehetösen távol áll egymástól. A számszerüsitési eljárások az elmélet absztrakcióit nem képesek követni, az adatok rendelkezésre állása pedig a csalás szempontjából amúgy is kritikus. Azonban az elmélet széleskörü ismerete megóvhat attól, hogy hamis következtetéseket, nem megalapozott általánosításokat alkalmazzunk. Ilyen például a kibocsátás rögzített arányához kötött adócsalás miatt nem megfigyelt hozzáadott érték becslésének példája is. Ugyanakkor a történeti sajátosságok miatt egyes tevékenységek Magyarországon gyakoribbak lehetnek, vagy mélyebben gyökerezhetnek a 
gazdaság müködésében, mint más országokban. A rendszerváltás elhúzódó folyamatait is figyelembe kell venni az áfacsalás alakulásának vizsgálatakor.

EO2: A RENDELKEZÉSRE ÁLLÓ BECSLÉSI MÓDSZEREK ÉRTÉKELÉSE AZ ÁFACSALÁS SZÁMSZERÜSÍTÉSÉNEK LEHETŐSÉGE SZEMPONTJÁBÓL

A számszerüsitési eljárásokat a becslés célja határozza meg. A nemzetközi irodalomban publikáló kutatóknak általában nem állnak rendelkezésére olyan részletezettségü adataik, mint a statisztikai hivataloknak. A számszerüsités célja sem ugyanaz. A statisztikai hivatalok számitásainak meg kell felelniük a nemzetközi elöirásoknak, európai uniós jogszabályoknak, ajánlásoknak. Ezek azonban nem tartalmaznak konkrét módszertani rendelkezéseket, leginkább a felhasznált adatokra fogalmaznak meg javaslatokat. Emiatt fordulhat elö, hogy bár adócsalást és az emiatt nem megfigyelt hozzáadott értéket részletesen kell számszerüsiteni, meg sincs publikált módszertan a megvalósitáshoz.

EO3: MikROADATOKAT TARTALMAZÓ ADATBÁZISOK ÖSSZEÁLLÍTÁSA A 20062016 KÖZÖTTI ÉVEKRE

A számszerüsités elvégzéséhez szükség volt a megfelelö adatbázisok összeállitására $A$ rendelkezésre álló adatbázisok alapvetően éves gyakoriságú táblákban voltak elérhetők, emiatt és az adatok folyóáras jellege miatt éves gyakoriságú összefüzött táblákat készitettem. A másik lehetöség egy konszolidált adatbázis elkészitése volt. Mivel azonban a fó cél az áfacsalás évenkénti számszerüsitése a vizsgált időszakra, ezért választottam az évenkénti adatbázist. A munka során a megfelelö adatbázisok összeállitása, az adatok vizsgálata és tisztítása jelentette a leghosszabb munkafolyamatot.

Az adatbázis legfontosabb összetevője az áfaellenörzés adatbázis volt. Ehhez füztem hozzá a többi, nem ellenörzött szervezetet, az éves beszámoló adatokat, az áfabevallás adatokat és a kategória jellegü változókat. A rendelkezésre álló változókból további, föként arány jellegü változókat számítottam ki.

EO4: AZ ÁFACSALÁS JELLEGZETESSÉGEIT FIGYELEMBE VÉVE MEGFELELŐ BECSLÉSI MODELL FELÁLLÍTÁSA

Az adatbázisok összeállitása a modell illesztését is meghatározta, minden évre külön-külön hajtottam végre a becslést. Mivel az áfacsalás változatos 
motivációira és történeti hagyományokon alapuló tradicióira nem állnak rendelkezésre adatok - ezeket nem is lehetne mérni - ezért a becslési eljárás kiválasztásánál a nemparaméteres eljárások közül választottam a kNN módszert. Ez a gépi tanulásos eljárás nagyon egyszerü, a megfigyelések közti hasonlóságok alapján végzi el a becslést. Az eredményre vezetö folyamat nem interpretálható, de ilyen komplex jelenség esetén ez nem is volna lehetséges.

EO5: A BECSLÉS VÉGREHAJTÁSA A 2006-2016-OS ÉVEKRE, AZ EREDMÉNYEK ÉRTÉKELÉSE, VALIDÁLÁSA

A kNN becslést a vizsgált években az áfacsalás imputálására hajtottam végre. Az eredményeket az elméleti áfa bevétel arányában érdemes értékelni. Az eredmények alakulásából és ágazatos megoszlásából az látszik, hogy az áfacsalás 2011-ig emelkedett, ekkor közel 29\%-os szintet ért el. Ezután 2016-ig drasztikusan, 10\%-ra csökkent.

EO6: A GAZDASÁGI NÖVEKEDÉS ÉS VÁLSÁG HATÁSÁNAK KIMUTATÁSA AZ ÁFACSALÁS ALAKULÁSÁBAN MAGYARORSZÁGON

2012-töl a kormányzat olyan intézkedéseket hozott, amelyek az áfacsalás csökkentésére irányultak, ebben az idöszakban az áfarés folyamatosan és nagymértékben csökkent. . Ugyanakkor 2013-tól az országban elindult a gazdasági növekedés a korábbi válság után. A gazdasági növekedéssel együtt a hozzáadott érték és így az elméleti áfa is növekedni kezdett. Rendkívül érdekes a kérdés, hogy a gazdasági növekedés mennyiben határozta meg az áfarés csökkenését. Erre megyei szintü panel modell illesztésével kerestem a választ. Eredményem szerint az egy före jutó reál GDP egységnyi változása minden egyéb változatlansága mellett megyei szinten 3\%-ponttal csökkenti az áfarés nagyságát. Ki kell még emelni, hogy egy esetleges válság a GDP visszaesése mellett „, extra” mértékben növeli az áfarés nagyságát. Ennek oka, hogy a válsággal járó bizonytalanság a több területre kiterjedö problémák különösen motiválják az áfacsalást.

\subsubsection{Az értekezés korlátjai}

Az értekezés készítése során több lehatárolást is szükséges volt tennem. 
- A számszerüsítés Magyarországra vonatkozik, a Magyarországon teljesített tranzakciók körében elkövetett áfacsalás nagyságát becsüli meg. Így az itt feltárt összefüggések más országokra nem általánosíthatók. Az adatok más országok hasonló adatsoraival sajnos nem összehasonlíthatók, mivel ilyenek nem kerültek publikálásra.

- A számszerüsítés a 2006-2016 éveket fedi le. Ennek oka egyszerüen a rendelkezésre álló adatok korlátosságából adódik. 2006 előtti évekre nem állt rendelkezésemre áfaellenőrzés adatbázis. 2016 utáni évekre pedig még nincs elég jogerős áfaellenőrzés eredmény. Terveim szerint a jövőben a becslést folytatni fogom a további évekre is, amint az adatok rendelkezésre állnak.

- A becslés a teljes áfacsalásra készült. Nem alkalmas arra, hogy a különböző áfacsalás kategóriákat ebből kimutassam, vagy pedig a résztvevők motivációit feltérképezzem. Erre az általam alkalmazott kvantitatív módszer nem nyújt lehetőséget.

- Az eredmények validálása a jelenség szenzitivitása miatt nehezen megoldható.

A korlátokat felismerve és vállalva arra törekedtem, hogy a kutatás megközelítési módját és módszertani elemeit megfelelően összehangoljam annak érdekében, hogy az eredmények hitelessége és bemutathatósága ne szenvedjen csorbát.

\subsection{Köszönetnyilvánítás}

Mindenekelőtt szeretnék köszönetet mondani témavezetőmnek, Dr. Sugár Andrásnak a segítségéért, ahogy az elméleti és módszertani kérdések között segített eligazodni, és a kutatási témámat megfelelő elméleti és gyakorlati keretrendszerben elhelyezni.

Köszönöm szépen kollégámnak Máténé Bella Klaudiának a sok módszertani segítséget és az együtt gondolkodást, kutatást, amely nélkül a primer kutatás nem valósult volna meg. Köszönöm Dr. Cseh Tímeának a sok hasznos észrevételt, amely a dolgozat formába öntését és érthetőségét nagymértékben elősegítette.

Köszönöm szépen a Központi Statisztikai Hivatalnak, munkahelyemnek, hogy számomra a kutatást anyagi hozzájárulásával lehetővé tette, és a Nemzeti számlák főosztály minden kollégájának, hogy az inspiráló munkahelyi környezettel kutatásomat elősegítette.

Végezetül köszönöm szépen családomnak a sok-sok türelmet és támogatást, amely nélkül ez a dolgozat nem készült volna el. 


\subsection{Az értekezés szerkezete}

Az értekezés további fejezeteinek szerkezete a következő:

- A 2. fejezet bővebb szakirodalmi áttekintést tartalmaz a szabályszegő magatartás elméletéről és a nem megfigyelt gazdasági tevékenységek magyarországi történetéröl.

- A 3. fejezet a nem megfigyelt gazdasági tevékenységek számszerüsítési lehetőségeinek irodalom áttekintését tartalmazza.

- A 4. fejezetben a primer kutatásom eredményeit ismertetem. A fejezet főbb részei:

○ alapadatbázisok összeállítása

○ mutatók képzése, eloszlások vizsgálata

○ outlierszürés

○ becslés eredményei

○ gazdasági növekedés hatásának kimutatása az áfacsalás idősorban

- Az 5. fejezetben az eredmények felhasználhatóságát és a kutatás lehetséges kiterjesztését ismertetem.

\section{Az adócsalás elméletének és magyarországi történetének áttekintése}

A fejezetben ismertetem az adórendszer főbb ismérveit, az áfa elhelyezkedését az adórendszeren belül, valamint az adócsalás fogalmát, jelentőségét a nemzeti számlák összeállítása szempontjából. Ezt követően bemutatom a szabályszegő és adócsaló magatartás fontosabb elméleti vonatkozásait és a nem megfigyelt gazdaság történeti hátterét.

\subsection{Adózás, adóelkerülés, adócsalás}

Ebben az alfejezetben a dolgozat megértéséhez szükséges legfontosabb adózási alapfogalmakat tisztázom. Mivel a kutatás célja az áfacsalás becslése és alakulásának vizsgálata, elsőként az adót és az áfát definiálom, majd az adóelkerülés, adócsalás fogalmak meghatározása következik.

\subsubsection{Az adó - rövid áttekintés}

A kormányzat fenntartásához, a kormányzat által vállalt feladatok ellátásához bevételek szükségesek. A bevételek csoportosítását a következö, 2. ábra tartalmazza. 
2. ábra: A kormányzat bevételeinek csoportosítása

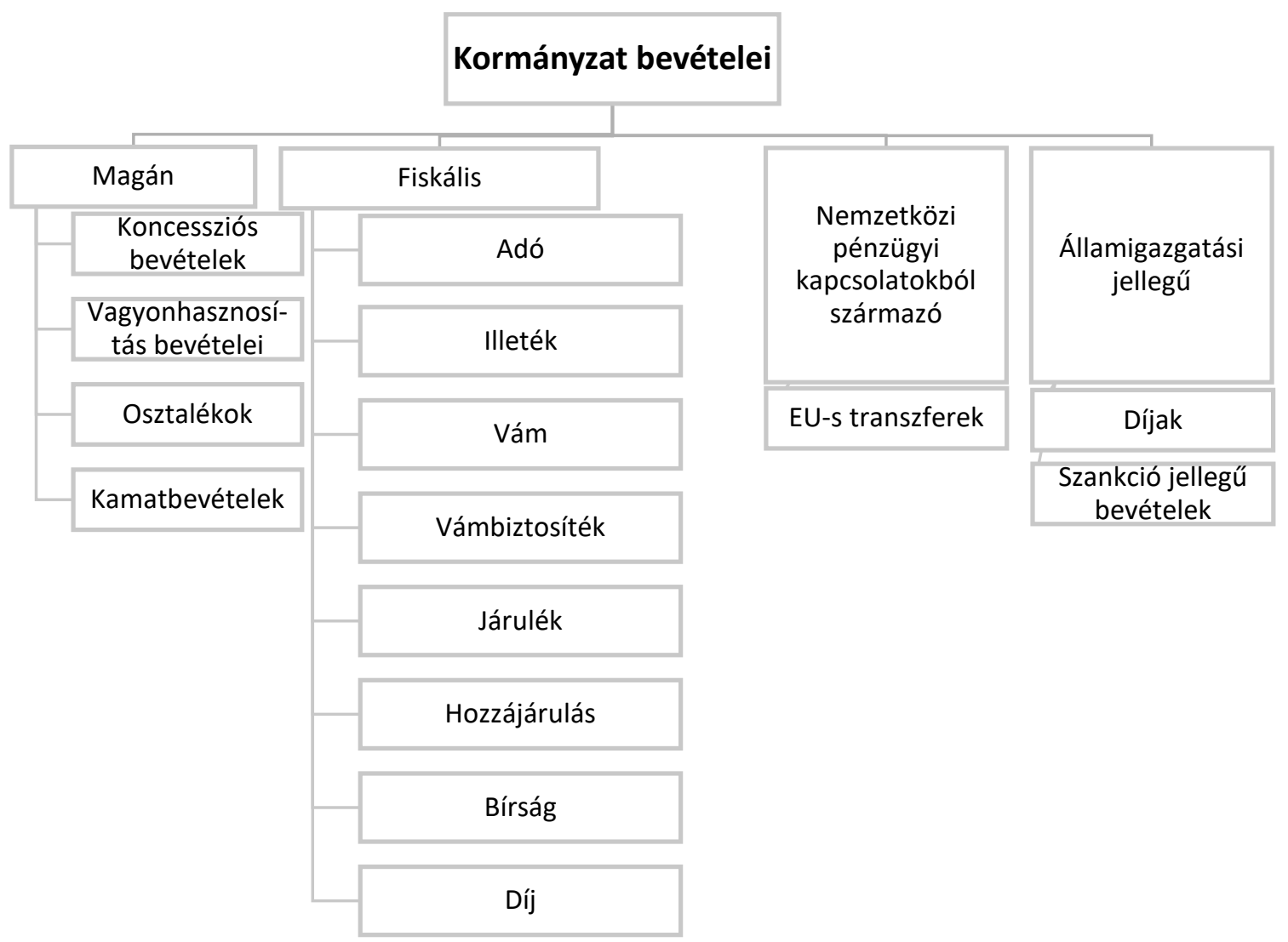

Forrás: (Pénzügysziget, 2020)

https://penzugysziget.hu/index.php?option=com_content\&view=article\&id=3209:az-ado-fogalma-csoportositasaes-az-adozassal-kapcsolatos-alapfogalmak-ismertetese \&catid=124\&Itemid=53 alapján saját szerkesztés

Az 2. ábra alapján az adó a kormányzat fiskális bevételeinek egyik tétele. Az adó olyan állami bevétel, amely közvetlen ellenszolgáltatás nélkül, az állam által egyoldalúan megállapított és kényszer útján behajtható. Az adó kivetésére csak az állam által meghatározott szerv jogosult, megfizetési kötelezettségét csak jogszabály írhatja elő, és csak pénzben teljesíthető. Az adókat számos szempont szerint csoportosíthatjuk, a 3. ábra a lehetséges csoportosításokat mutatja be. 


\section{3. ábra: Az adók csoportosításának fontosabb szempontjai}

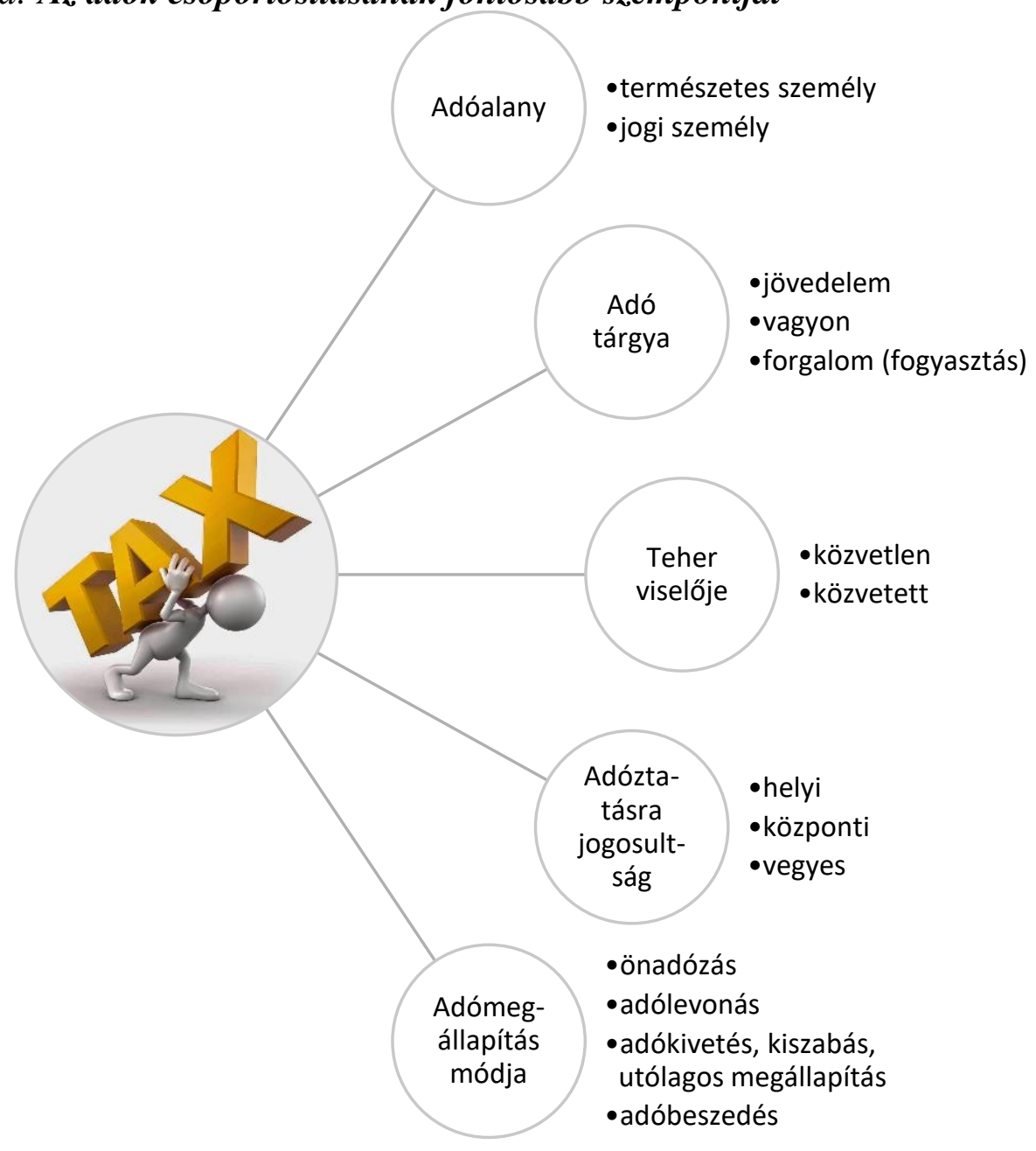

Forrás: (Pénzügysziget, 2020)

https://penzugysziget.hu/index.php?option=com_content\&view=article\&id=3209:az-ado-fogalma-csoportositasaes-az-adozassal-kapcsolatos-alapfogalmak-ismertetese \&catid=124\&Itemid=53 alapján saját szerkesztés

Az áfa a 3. ábra alapján olyan központi, közvetett adó, amelyet önadózással fizetnek meg a gazdasági szereplők, és amelynek természetes és jogi személyek is lehetnek az alanyai. Az áfa olyan többfázisú, nettó típusú adó, melyet a termelés és a forgalmazás minden szakaszában a hozzáadott érték után kell fizetni, de az adóterhet a termék vagy szolgáltatás végső felhasználója viseli.

Az áfa azért többfázisú, mert a termelési folyamat minden fázisát érinti. A gazdasági szereplők az értékesítésük után áfát számítanak fel, amit a vevő megfizet, ezt nevezzük fizetendő áfának. Az eladó beszerzései után megfizetett áfát visszaigényelheti, ez az előzetesen felszámított vagy levonható áfa. A költségvetésnek csak a fizetendő és az előzetesen felszámított áfa közti különbséget kell befizetnie, emiatt az áfa nettó típusú 
adó. Az értékesítésre jutó áfa az eladónak nem jelent árbevételt, mivel azt be kell fizetnie a költségvetésbe. Az áfa a számlaadási kötelezettségre épül.

A fogyasztók az áfát nem igényelhetik vissza, így a termék értéke utáni összes adóterhet végső soron a fogyasztók fizetik meg. Meg kell még említeni, hogy a vállalkozások, abban az esetben, ha nem áfa alanyok, nem igényelhetik vissza a beszerzéseik után megfizetett áfát.

Ki kell emelni továbbá, hogy az áfa területi hatálya alapján az adott ország országhatárain belüli termékértesítés, szolgáltatásnyújtás értéke után kell az adót megfizetni. Az áfát a 2007. évi CXXVII. törvény az általános forgalmi adóról szabályozza. A 2007. évi CXXVII. törvény $2 . \S$ alapján adót kell fizetni:

a) adóalany által - ilyen minőségében - belföldön és ellenérték fejében teljesített termékértékesítése, szolgáltatásnyújtása,

b) terméknek az Európai Közösségen (a továbbiakban: Közösség) belüli egyes, belföldön és ellenérték fejében teljesített beszerzése és

c) termék importja

után.

Az áfa szempontjából a tranzakció teljesítésének a helye az úgynevezett „láncügyletek” esetében az áfatörvényben külön meghatározott. Ezek a tranzakciók különösen sok lehetőséget nyújtanak az áfa kötelezettségek kikerülésére, ezért tartom fontosnak ezek kiemelését. A láncügylet kifejezést az áfatörvény nem használja, a szakzsargonban használatos kifejezés olyan tranzakció sorozatot takar, amely az áfatörvény 26-27 paragrafusaiban van körülírva. A láncügylet során több adásvétel történik a résztvevők között, azonban az ügylet során a termék fizikailag a lánc elején álló szereplőtől a lánc végén álló szereplöhöz kerül közvetlenül. 


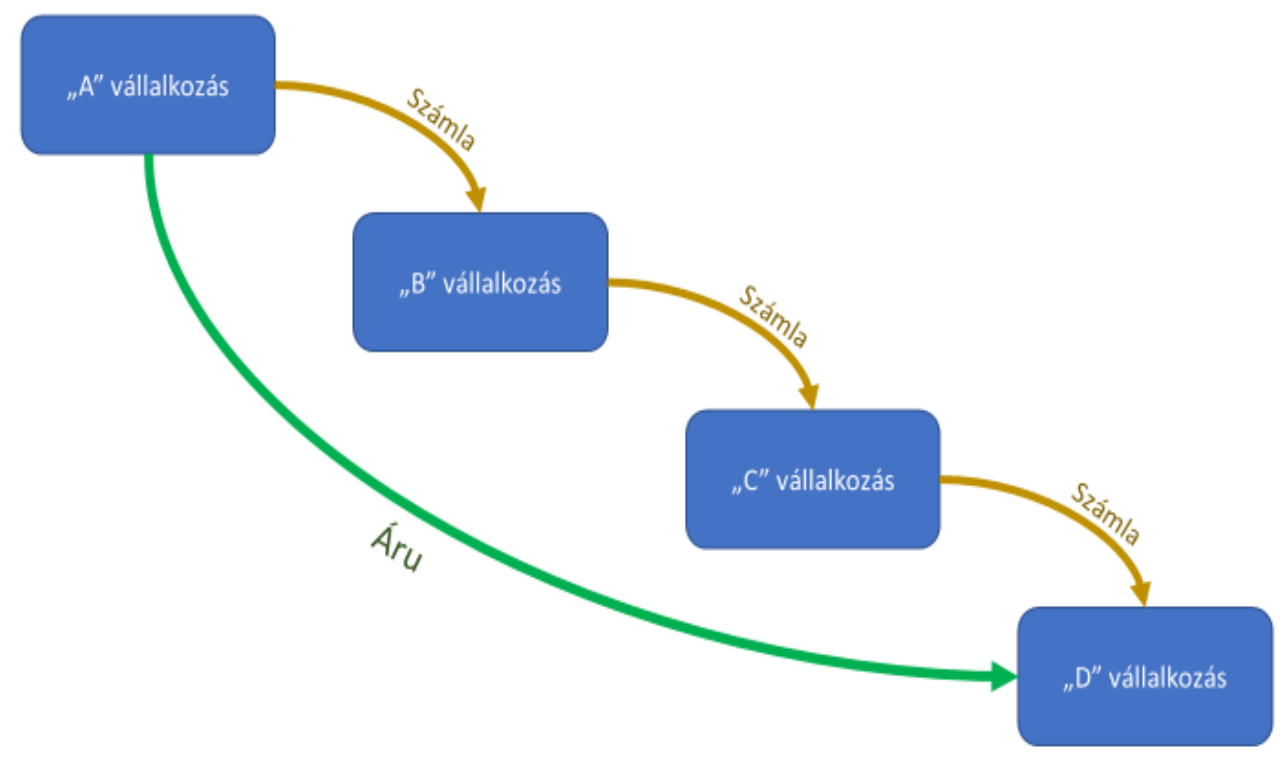

Forrás: saját szerkesztés

A 4. ábra egy lehetséges láncügyletet mutat be. Az „A” vállalkozás eladja a terméket „B”nek, aki továbbértékesíti „C”-nek, végül „C” „D” vállalkozásnak értékesíti a terméket. Az eladott áru azonban a láncügyletek esetében „A” vállalkozástól közvetlenül „D” vállalkozáshoz kerül. A láncügyletek elszámolása az ügylet területi hatályának meghatározása miatt meglehetősen bonyolult. Az ügyletek teljesítésének a helye a fuvarozó cég láncban elfoglalt helyétől függ. A fuvarozással érintett ügylet teljesítési helye ott van, ahol az áru feladása megtörténik. A többi, nem fuvarozási ügylet teljesítési helye attól függ, hogy a láncban megelőzi vagy követi a fuvarozással érintett ügyletet.

Azok az ügyletek, amelyek megelőzik a fuvarozással érintett ügyletet, a fuvarozás megkezdésének országában tekintendők teljesítettnek. Azok az ügyletek, amelyek a fuvarozással érintett ügyletet követik, a rendeltetési országban kerülnek elszámolásra. Mivel a fuvarozó cég két ügyletben is érintett, az általa elszámolt ügyletek esetében a teljesítés helye attól függ, hogy vevőként, vagy eladóként végzi-e a fuvarozást. Az áfatörvény $27 . \S$-a föszabályként a vevőként bonyolított fuvarozást alkalmazza. (ado.hu, 2020) https://ado.hu/ado/lancugyletek-afa-es-szamlazas/ 
Az áfa a hazai költségvetés legjelentősebb adóbevétele, az adóbevételek között 2018-ban 39\%-os részarányt képviselt. ((d), 2020) Az 5. ábra az áfa bevétel alakulását és az adóbevételeken belüli arányának alakulását mutatja meg.

\section{5. ábra: Az áfa bevételek és az áfa bevétel arányának alakulása az összes} adóbevételen belül 1995 és 2018 között Magyarországon

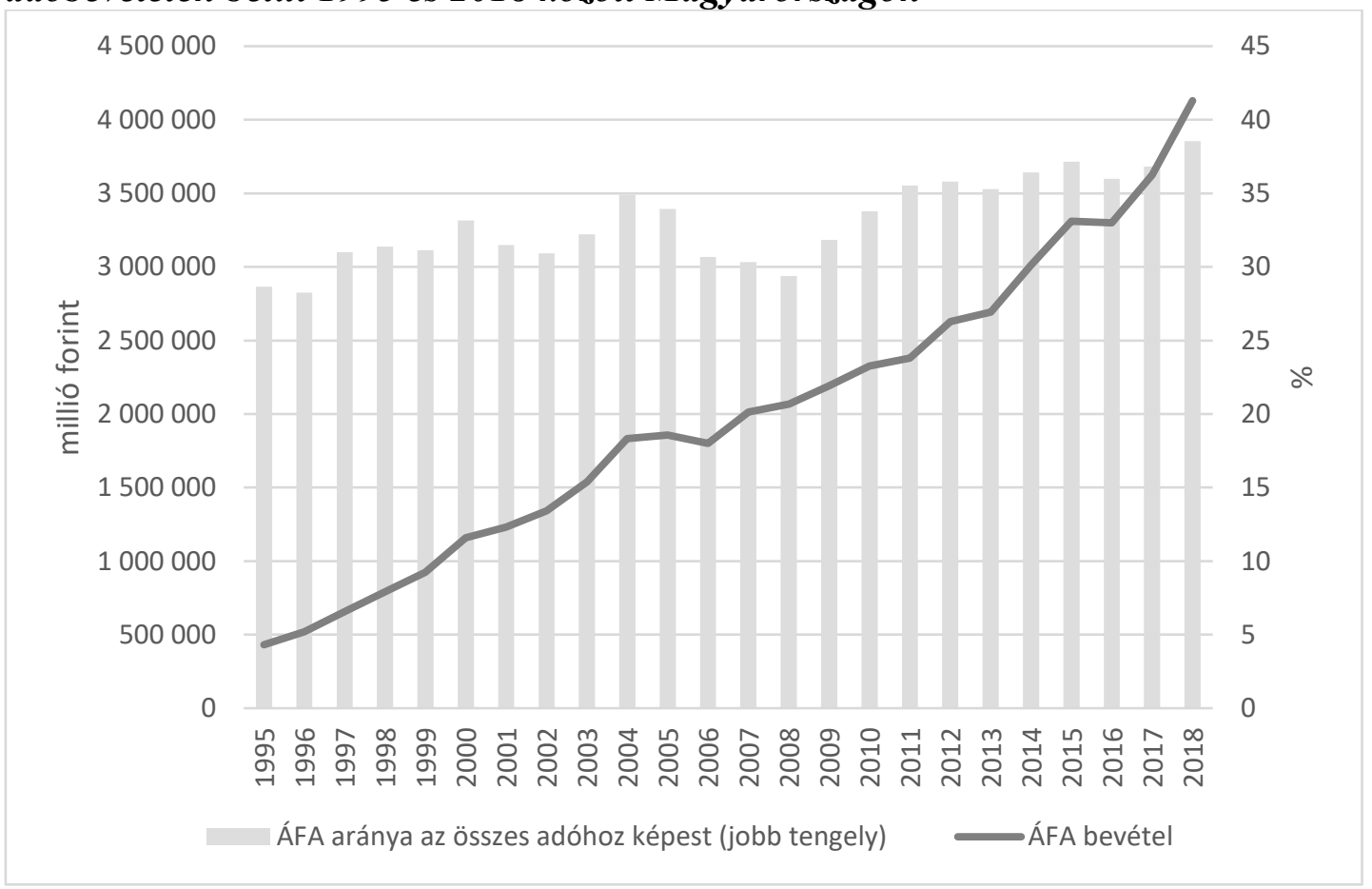

Forrás: ((d), 2020), 3.1.26.2 tábla

Az 5. ábra alapján látható, hogy az áfa aránya az 1995-ös 29\%-ról 2018-ra 39\%-ra emelkedett. Számottevő súlya miatt beszedése rendkívül fontos, és az áfával való visszaélés jelentős költségvetési kockázatot jelent. Mivel azonban számlaadáshoz kötött adó, továbbá elszámolása és szabályozása rendkívül bonyolult, mint ahogy a láncügyletek elszámolása esetében is látható volt, az adócsalásra, a befizetése alóli kibúvásra jelentős a motiváció.

\subsubsection{Az áfa története}

Az áfa ötlete eredetileg von Siemens német üzletembertől származott, aki a fogyasztási adók által okozott halmozódás kiküszöbölésére találta ki az új koncepciót. (James, 2011) Gyakorlati megvalósítására az 1950-es években került sor, az ötlet megvalósítója Maurice Lauré volt, a francia adóhatóság akkori igazgatója. (Frunza, 2020) Az új adó az Európai Gazdasági Közösségben 1967 áprilisában került bevezetésre a tranzakciók teljes értékére, annak érdekében, hogy az indirekt adók torzító hatását elkerüljék. Az áfa bevezetését a 
67/227/EEC rendelet szabályozta. (Borselly, 2011) Elődje számos országban kaszkád jellegü fogyasztási adó (másként lépcsőzetes adó) volt, amelyet az értékesítési lánc minden szintjére kivetettek, levonási lehetőség nélkül. Az adó halmozódása vertikális integrációra ösztönzött, és a tőketényezők beszerzése miatt fellépő problémák a gazdasági fejlődés útjába álltak. Más országokban egyszintű volt az adó, azonban bármely szintjére is vetették ki a termelési láncnak, sok gondot okozott, és eltorzította a gazdasági szerkezetet. (Tait, 1988)

A piacgazdaságra áttérő volt szocialistaországok gyorsan bevezették az új adót, jelenleg világszerte mintegy 140 ország alkalmazza az áfát. (Borselly, 2011) Világszinten az adóból származó bevételek mintegy 20\%-át teszik ki az áfa bevételek. A legjelentősebb kivétel az Egyesült Államok, ahol ezt az adónemet egyelőre nem alkalmazzák. Az áfa alkalmazásának három prototípusa létezik világszerte. Az új-zélandi modell az áfa ideális formájának tekinthető, mert egy kulcsot alkalmaz és a termékek és szolgáltatások lehető legszélesebb körére kiterjed a hatálya. Az európai áfarendszer több kulcsot és a kivételek garmadáját alkalmazza. A japán rendszer jellemzője a kifejezetten alacsony áfakulcs. (James, 2011)

Az áfa hozzáadott érték jellegű adó, a hozzáadott érték ellenben input és output oldalról is meghatározható. Továbbá az adót az összetevőkre és az eredményre is ki lehet vetni. A többféle alternatív közül az áfa $=t$ (output) $-t$ (input) megoldás lett általános elfogadott Európában. Ezáltal azonban az áfát a tranzakciókhoz kötötték, és így szükségszerűen indirekt adó lett. A tranzakciók bizonylata a számla, ami az ellenőrzések alapja a többi adónemmel ellentétben, ahol a könyvelés az ellenőrzés alapja. (Tait, 1988) Az áfát Magyarországon 1988-ban vezették be a személyi jövedelemadóval együtt. Bevezetését azzal indokolták, hogy az erőforrások helyett a fogyasztás adóztatása a vállalatok számára kedvezőbb helyzetet teremt. Korábban a vállalatok voltak az adóbevételek fö forrásai. A magas elvonások azonban ellenérdekeltté tették őket termelésben, a költségelszámolásuk bonyolult volt, mert az erőforrásokat terhelő adók nem az erőforrások felhasználásánál, hanem nyereség terhelő adóként jelentek meg. Az új adórendszer ezzel szemben jobban bevonta a háztartásokat a közfinanszírozásba és a kormányzati szándék szerint a pénz felhasználásába is nagyobb beleszólást kaptak. (Ez utóbbi célitüzés a gyakorlatban nem valósult meg.) 
Az új adórendszer emellett előkészítette a nyitást a fejlett országok felé azzal, hogy hasonló adórendszert valósított meg.

A bevezetés tapasztalatai nem támasztották alá a várakozásokat. A költségvetés centralizációja nem csökkent, a hatékonyság nem emelkedett. Ellenben a lakossági terhek emelkedtek a vállalati terhek csökkenése mellett, és az egész folyamat inflációs nyomást váltott ki. Az áfa aránya a költségvetés adó és adójellegü bevételei között bevezetésétől kezdve emelkedett, az 1988-as 17,3\%-ról 1995-re több, mint 10 százalékponttal nőtt. Eközben a társasági adó aránya 12,3\%-ról 3,5\%-ra csökkent ugyanezen időszak alatt. Az adórendszer átalakítása nyomán a vállalatok eredményessége nem javult . (Ékes, 1997)

\subsubsection{Adócsalás a nemzeti számlákban}

A nemzeti számlák korai publikációiban a nem megfigyelt tevékenységek még nem szerepeltek külön kimutatva. Ennek alapvetően két oka volt. Egyrészt a nemzeti számlák koncepcióinak kidolgozói inkább makro szemléletű szakemberek voltak, a makro és mikro adatok összekapcsolása nem volt napirenden. Az adócsalás problémája a nyolcvanas években merült fel, amikor a mikro és makroadatok összekapcsolhatósága a rendelkezésre álló üzleti beszámolók miatt lehetővévált. Az egyedi szintű adatok makrostatisztikai adatokká történő konvertálása egy közbülső számítási szintet tesz szükségessé, ahol az egyedi szinten nem kiszámítható tételek miatti kiigazításokat (például az adócsalás miatti kiigazításokat) el lehet végezni. (Vanoli, 2005) A Process table szemlélet ennek a koncepciónak a gyakorlati megvalósulása. (Murai, 2011)

Másrészt a termelés lehatárolása kapcsán vetődött fel a törvénysértő tevékenységek elszámolása. Kuznets és Pigou nézete szerint a törvényi tiltás nem ok nélküli, a törvénysértő tevékenységek káros hatásúak a társadalomra. Ezért hallgatólagos tradíció volt a nemzeti számlák összeállítóinak körében, hogy az illegális és föld alatti tevékenységeket nem számolták el. Az illegális tevékenységek, informális gazdaság elszámolása és a földalatti gazdaság az 1993-as SNA-ba került be. (Vanoli, 2005) Elszámolásuk a koherens és konzisztens makrostatisztikai adatok előállítása céljából vált szükségessé.

A kiegészítés oka, hogy a nem megfigyelt és megfigyelt gazdaság egymástól nem szervesen szétválasztható egy nemzetgazdaságban. A megfigyelt és nem megfigyelt gazdaság a jövedelemszerzés, termelés és árupiac vonatkozásában egyaránt szorosan összefonódott. Ezt azt jelenti, hogy például a jövedelmek, függetlenül azok 
megszerzésétől megjelenhetnek a megfigyelt áruk piacán. Vagyis, ha például a nem megfigyelt jövedelmeket nem vesszük számításba, akkor a jövedelem, fogyasztás és megtakarítás egyensúlya nem jön létre. Hasonlóan a nem megfigyelt termékek iránti keresletet az árupiac kínálati oldalán ki kell mutatni, különben az árupiaci egyensúly sérül. A nem megfigyelt gazdaság elszámolásának hiánya a különböző adatforrások közti diszkrepancia egyik oka lehet.

Továbbá az egyes országok szabályrendszere és kulturális környezete eltérő. Például bizonyos illegális tevékenységek más országokban a legális gazdaság részét képezik, ilyen a drogkereskedelem, amely Hollandiában részben legális. Ezért a nem megfigyelt gazdasági tevékenységek elszámolása teszi lehetővé az egyes országok adatainak összehasonlíthatóságát. Az elszámolandó tevékenységek köre azonban további pontosításra szorul.

Nemzeti számlák összeállításának elengedhetetlen feltétele a termelés lehatárolása. A termelés körébe tartozó tevékenységeket az alábbi 6. ábra alapján lehet besorolni.

\section{6. ábra: A termelés határa}

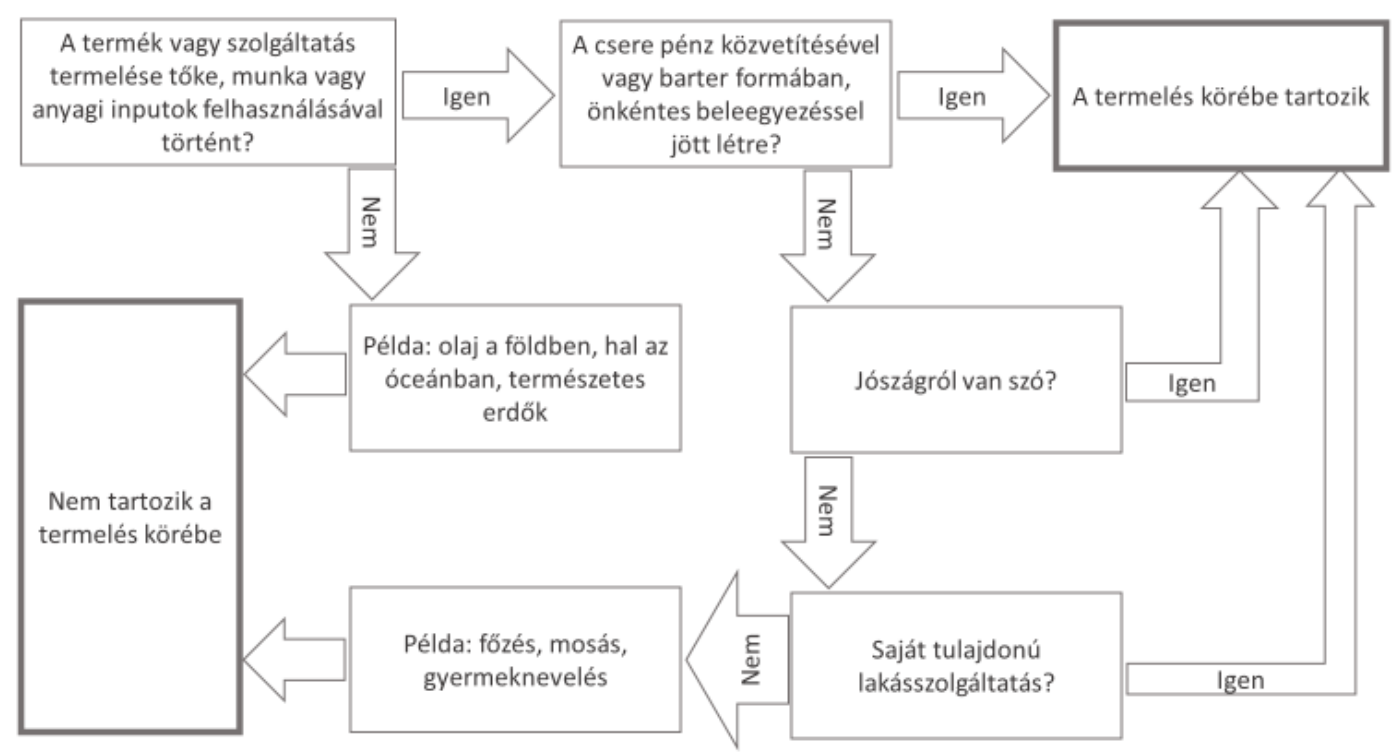

Forrás: (Fanelli, Ahmad, \& Pinto, 2004)

A 6. ábra alapján jól látható, hogy azok a tevékenységek, amelyek pénz közvetítésével cserélnek gazdát, a termelés körébe tartoznak, tehát a nemzeti számlákban szerepelniük kell. 
A termelés keretrendszerével összhangban az ESA2010 tartalmazza a 3.08 paragrafusában azt, hogy a termelést attól függetlenül számításba kell venni, hogy az illegális vagy nem regisztrált tevékenység eredménye. (Official Journal of the European Union, 2013) Továbbá az 527/98/EC határozat kijelenti, hogy a beszedett, de a kormányzatnak nem továbbított adót a kibocsátás részeként kell elszámolni a nemzeti számlákban, mivel az a vállalkozás jövedelmét növeli.

Az adócsalás a nem megfigyelt gazdaság része, amely számos különböző tevékenységet magában foglal. A nem megfigyelt gazdasági tevékenységekre két általánosan elfogadott csoportosítás létezik, mégpedig az OECD és az Eurostat által kidolgozott kategóriarendszer. (OECD, 2002), (Eurostat, 2005)

\section{1. táblázat: A nem megfigyelt tevékenységek csoportosítása}

\begin{tabular}{|c|c|c|c|}
\hline \multirow{8}{*}{ 己े } & \multirow[t]{2}{*}{ Földalatti gazdaság } & $\begin{array}{l}\text { N1 Regisztrálásra kötelezett termelök } \\
\text { termelése, akik elmulasztották a regisztrációt } \\
\text { (földalatti termelés) }\end{array}$ & \multirow{8}{*}{ 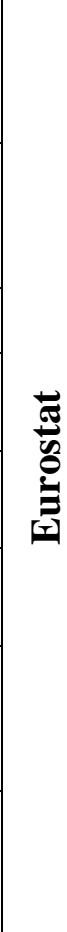 } \\
\hline & & $\begin{array}{l}\text { N6 A hivatalos nyilvántartásokból torzított } \\
\text { adatközlés miatt kimaradó gazdasági } \\
\text { teljesítmény }\end{array}$ & \\
\hline & Illegális gazdaság & N2 Illegális termelés & \\
\hline & \multirow[t]{3}{*}{ laság } & $\begin{array}{l}\text { N3 Regisztrációra nem kötelezett kistermelök } \\
\text { termelése }\end{array}$ & \\
\hline & & $\begin{array}{l}\text { N4 Statisztikai megfigyelésekből kimaradó } \\
\text { társas vállalkozások termelése }\end{array}$ & \\
\hline & & $\begin{array}{l}\text { N5 Statisztikai megfigyelésekből kimaradó } \\
\text { egyéni vállalkozók }\end{array}$ & \\
\hline & $\begin{array}{lr}\begin{array}{l}\text { Háztartások termelése } \\
\text { saját } \\
\text { felhasználásukra }\end{array} \\
\end{array}$ & $\begin{array}{l}\text { N3 Regisztrációra nem kötelezett kistermelők } \\
\text { termelése }\end{array}$ & \\
\hline & $\begin{array}{l}\text { Hiányzó termelés az } \\
\text { adatgyüjtési programok } \\
\text { hiányosságai miatt. }\end{array}$ & $\begin{array}{l}\text { N7 Egyéb statisztikai hiányosságok (Hiányzó } \\
\text { adatok nem megfelelö kezelése vagy nem } \\
\text { megfelelően rendelkezésre álló adatok) }\end{array}$ & \\
\hline
\end{tabular}

Forrás: (Eurostat, 2005) (OECD, 2002)

A kétféle csoportosítás a statisztikai számításba vételt segíti elö, ugyanakkor segít elhelyezni és értelmezni számos, köznyelvben előforduló, a nem megfigyelt tevékenységekre használt kifejezést. ${ }^{1}$ A dolgozat a földalatti gazdaság területével foglalkozik, közelebbről azzal az adóval, amit az N6, a hivatalos nyilvántartásokból torzított adatközlés miatt kimaradó gazdasági teljesítményhez köthető. Az adók és

\footnotetext{
${ }^{1}$ A köznyelvben elterjedt még a fekete- és szürkegazdaság kifejezés is. Ezek nem egzakt fogalmak, a feketegazdaságon általában az illegális tevékenységeket, a szürkegazdaságon pedig az adócsalást értik, de sok esetben a használatuk nem egyértelmü.
} 
járulékok minimalizálása miatt nem megfigyelt teljesítmény tartozik ide, az áfacsalás miatt nem megfigyelt teljesítményeket is itt vesszük számításba.

Az áfacsalás főbb területei:

- fekete gazdaság

- nem teljesítések

- közösségen belüli kereskedelemhez kapcsolódó áfacsalás (missing trader fraud), ilyen az akvizíciós és a körhinta csalás. Leginkább elterjedt területei: számítógépek, mobiltelefonok, gépkocsik és autóalkatrészek, hús, olaj, gabona, üdítők, kozmetikumok, nemesfémek és elektronikus fogyasztási cikkek nagykereskedelme. (Borselly, 2011) Az ezredforduló után a széndioxid kvótákkal történő körhinta csalás az egyik legjövedelmezőbb csalási forma, amely jelentős károkat okoz. (Frunza, 2020)

- közösségen kívüli kereskedelem

- jogosulatlan visszaigénylések; nem valós input számlák, nem üzleti célú vásárlások elszámolása

- kibocsátás utáni áfa meg nem fizetése, valóságosnál alacsonyabb értékesítés elszámolása, adó beszedése a kormányzatnak való befizetés elmulasztásával - javak hibás besorolása alacsonyabb áfakulcsú termékként (Sokolovska, 2016),

Az áfacsalás sokszor összefonódik a szervezett bünözéssel, egyrészt az így szerzett jövedelem más büncselekmények pénzügyi forrása lehet, ill. az áfacsalásra alapított tevékenységek a pénzmosással is összefonódhatnak. (Borselly, 2011)

\subsubsection{Adócsalás jogi háttere}

Az adózást szabályozó jogszabályok a jogalkotó szándékának egyfajta vetületét jelentik, amely egy komplex szabályrendszerben valósul meg. Ezek a szabályok, éppen azért, mert a jogalkotó szándékának tökéletesen megfelelő rendszert lehetetlen alkotni, lehetőséget nyújtanak arra, hogy a szabályok betartása mellett olyan adózói magatartás valósuljon meg, amely a jogalkotó szándékával nem egyezik meg. Ezek a tevékenységek legálisak, céljuk az adó minimalizálása. Ide tartozik az adótervezés, adóoptimalizálás, nemzetközi adóeltérések kihasználásából eredő adóminimalizálás, a törvény adta lehetőségek, kiskapuk bármilyen kihasználása. Ezeknek a tevékenységeknek a volumenét, hatását az adókra lehetetlen megbecsülni, mindazonáltal néhány esetben akár jelentős makrogazdasági hatással lehetnek. Például 2015-ben több multinacionális vállalat 
Írországba tette át a székhelyét adóoptimalizálási okokból, ennek következtében ezeknek a vállalatoknak a teljes globális profitja Írországban lett elszámolva. Ennek hatására az ír GDP volumene 2015-ben 26,3\%-kal emelkedett az előző évhez képest. (hvg.hu, 2016)

A nemzetközi adóoptimalizálást elősegíti az egyes országok adórendszere valamint a pénzügyi és adórendszerének átláthatósága és titkossága. A külön megegyezéseken alapuló adóztatás, a titkos adatkezelés nem csak az amúgy legálisan adóoptimalizáló cégeket segíti, hanem az adócsalókat, a szervezett bünözői csoportokat és a korrupt politikusokat. Az átláthatatlanság jelentős társadalmi veszteséget okoz világszerte (Dobsi, 2018).

Az adócsalás és az adóelkerülés közötti határt a jogszabályi környezet jelöli ki. Mivel az adócsalás a költségvetés biztosításának szempontjából jelentős veszélyt jelent, indokolt, hogy az állam büntetőjogi szankciókat is meghatározzon az adócsaló magatartással szemben az igazgatási jellegü eljárások mellett.

A dolgozatban vizsgált időszakban a Büntető Törvénykönyv megváltozott. 2011. december 31-ig az 1978. évi IV. törvény a Büntető Törvénykönyvről 310. §-a határozta meg az adócsalást. 2011. december 31. után az adócsalás helyett a költségvetési csalás elnevezést alkalmazta a törvény. 2013. július 1-jén lépett hatályba az új Btk., a 2012. évi C. törvény a Büntető Törvénykönyvröl. Az új Btk. megtartotta a költségvetési csalás elnevezést, jelenleg is ez a kifejezés áll a törvényben. A 2012. évi C. törvény a Büntető Törvénykönyvről a 396. §-ban a következő definíciót és büntetési tételeket adja meg a költségvetési csalásra vonatkozóan:

396. § (1) Aki

a) költségvetésbe történö befizetési kötelezettség vagy költségvetésböl származó pénzeszközök vonatkozásában mást tévedésbe ejt, tévedésben tart, valótlan tartalmú nyilatkozatot tesz, vagy a valós tényt elhallgatja, b) költségvetésbe történö befizetési kötelezettséggel kapcsolatos kedvezményt jogtalanul vesz igénybe, vagy

c) költségvetésböl származó pénzeszközöket a jóváhagyott céltól eltéröen használ fel,

és ezzel egy vagy több költségvetésnek vagyoni hátrányt okoz, vétség miatt két évig terjedö szabadságvesztéssel büntetendö.

(2) A büntetés büntett miatt három évig terjedő szabadságvesztés, ha 
a) a költségvetési csalás nagyobb vagyoni hátrányt okoz, illetve

b) az (1) bekezdésben meghatározott költségvetési csalást bünszövetségben vagy üzletszerüen követik el.

(3) A büntetés egy évtöl öt évig terjedő szabadságvesztés, ha

a) a költségvetési csalás jelentös vagyoni hátrányt okoz, vagy

b) a nagyobb vagyoni hátrányt okozó költségvetési csalást bünszövetségben vagy üzletszerüen követik el.

(4) A büntetés két évtöl nyolc évig terjedö szabadságvesztés, ha

a) a költségvetési csalás különösen nagy vagyoni hátrányt okoz, vagy

b) a jelentös vagyoni hátrányt okozó költségvetési csalást bünszövetségben vagy üzletszerüen követik el.

(5) A büntetés öt évtöl tíz évig terjedö szabadságvesztés, ha

a) a költségvetési csalás különösen jelentös vagyoni hátrányt okoz, vagy

b) a különösen nagy vagyoni hátrányt okozó költségvetési csalást bünszövetségben vagy üzletszerüen követik el.

(6) Az (1)-(5) bekezdés szerint büntetendö, aki a jövedéki adóról szóló törvényben, valamint a felhatalmazásán alapuló jogszabályban megállapitott feltétel hiányában vagy hatósági engedély nélkül jövedéki terméket elóállit, megszerez, tart, forgalomba hoz, vagy azzal kereskedik, és ezzel a költségvetésnek vagyoni hátrányt okoz.

(7) Aki költségvetésböl származó pénzeszközökkel kapcsolatban elöirt elszámolási, számadási, vagy az elöirt tájékoztatási kötelezettségének nem vagy hiányosan tesz eleget, valótlan tartalmú nyilatkozatot tesz, vagy valótlan tartalmú, hamis vagy hamisitott okiratot használ fel, büntett miatt három évig terjedö szabadságvesztéssel büntetendö.

(8) Korlátlanul enyhithetö annak a büntetése, aki az (1)-(6) bekezdésében meghatározott költségvetési csalással okozott vagyoni hátrányt a vádemelés elött megtériti. Ez a rendelkezés nem alkalmazható, ha a büncselekményt bünszövetségben vagy különös visszaesöként követik el. 
A bünszövetséget az 1978. év IV. tv. 137. § 7. pontja definiálta, az új definíció a 2012. január 1-jétől életbe lépő módosítással került a törvénybe. Az új Btk. a Záró rendelkezések fejezetben a 459. § 2. pontban határozza meg az alábbiak szerint:

2. bünszövetség akkor létesül, ha két vagy több személy büncselekményeket szervezetten követ el, vagy ebben megállapodik, és legalább egy büncselekmény elkövetését megkísérlik, de nem jön létre bünszervezet;

A bünszövetség a bünszervezettől a szervezettség fokában és az átmeneti jellegében tér el.

A vagyoni hátrány meghatározásához alkalmazott értékhatárokat szintén a Btk. tartalmazza, a jelenleg hatályos és a korábbi Btk. szerint a 2013. április 30. és 2013. július 1. között hatályos állapotot a következő táblázat mutatja meg.

2. táblázat: A jelenleg hatályos és az ezt megelöző állapot szerinti értékhatárok a vagyoni hátrány kategóriák szerint, forint

\begin{tabular}{|c|c|c|}
\hline $\begin{array}{l}\text { Vagyoni } \\
\text { kategóriák }\end{array}$ & $\begin{array}{l}\text { 1978. évi IV. tv } 138 / \mathrm{A} . \S \\
\text { (2012. II. tv. által } \\
\text { módosított értékhatárok) }\end{array}$ & $\begin{array}{l}\text { 2012. évi C. tv. } 459 \S(6)- \\
\text { jelenleg hatályos }\end{array}$ \\
\hline kisebb & $50000-200000$ & $50000-500000$ \\
\hline nagyobb & $2000000-2000000$ & $500000-5000000$ \\
\hline jelentős & $2000000-50000000$ & $5000000-50000000$ \\
\hline különösen nagy & $50000000-500000000$ & $50000000-500000000$ \\
\hline különösen jelentős & 500000000 & $500000000-$ \\
\hline
\end{tabular}

Forrás: az 1978. évi IV. tv és a 2012. évi C. tv. alapján saját szerkesztés

Az ötvenezer forintot meg nem haladó kár okozása esetében szabálysértés valósul meg. A költségvetési csalás esetében ettől eltér az értékhatár, 100000 forint a szabálysértés felső határa a Btk. 462.§ (3) pontja alapján Az előzőek alapján látható, hogy a Büntető törvénykönyv büncselekményként határozza meg az adócsalást (költségvetési csalást), amelyet szabadságvesztéssel szankcionál. A szabadságvesztés mértéke függ az elkövetés szervezettségétől, az üzletszerűségtől és az okozott kár mértékétől. Mindazonáltal a Büntető törvénykönyv a gazdasági büncselekmények szempontjából keretszabálynak minősül. Az adózás rendjét és az egyes adófajták alapján, mértékét, fizetésének szabályait egyéb jogszabályok tartalmazzák. Az áfát a 2007. évi CXXVII. törvény az általános 
forgalmi adóról szabályozza, míg az adózás rendjéről a 2017. évi CL. törvény az adózás rendjéről rendelkezik.

\subsection{5. Összefoglaló}

A kormányzat az általa vállalt feladatokat csak akkor képes ellátni, ha ehhez megfelelő források állnak rendelkezésére. A kormányzat legfontosabb bevételeit az adók jelentik, ezen belül Magyarországon a legjelentősebb tétel az áfa, az adóbevételek közel 30-40\%át teszi ki.

Az áfa számlaadáshoz kötött közvetett adó, amely esetében a teljesítés helye bizonyos esetekben nehezen megállapítható, mint ahogy azt a láncügyletek esetében részletesen bemutattam a 2.1.1 alfejezetben. Az adókon belüli aránya és a fizetési sajátosságai miatt az áfa jelentős költségvetési kockázatot jelent.

Az adócsalás a nem megfigyelt gazdaság része, a nemzeti számlák összeállításakor ezeket a teljesítményeket számításba kell venni az SNA és az ESA szerint, a konzisztens elszámolás, a nemzetközi összehasonlíthatóság biztosítása és a számítások teljessége érdekében.

Az adózói magatartás egyrészt adóelkerülés másrészt adócsalás (költségvetési csalás) miatt maradhat el a jogalkotók szándéka szerinti magatartástól Az adóelkerülés esetében az adózók élnek a törvény által nyújtott lehetőségekkel, kiskapukkal annak érdekében, hogy fizetési kötelezettségük minél kisebb legyen. Ez a magatartás legális, még akkor is, ha etikai szempontból megkérdőjelezhető. Az adócsalás esetében a Btk. határozza meg a bűncselekmény létrejöttének feltételeit. Adócsalás esetén az okozott kár mértékétől függően szabadságvesztés is kiszabható. Meg kell jegyezni, hogy az elhatárolás az adóelkerülés és az adócsalás között csak elméletileg egyértelmü.

A dolgozat az áfacsalás témakörét dolgozza fel, ezért az adóelkerülés nem témája a disszertációnak. A jelenleg hatályos Btk. a költségvetési csalás kifejezést használja a korábbiakban alkalmazott adócsalás kifejezés helyett. Mivel a dolgozat kifejezetten az áfacsalással foglalkozik, ezért a dolgozat további részében az adócsalás és áfacsalás kifejezéseket fogom használni.

\subsection{Az adócsalás elméleti háttere}

Az adócsalás szabályszegő magatartás, vizsgálatánál figyelembe kell venni, hogy a társadalomnak, közösségeknek szüksége van szabályokra, normákra, törvényekre. Az 
egyén nem függetleníthető a környezetétől. Az együttmüködés a társadalom müködőképességének alapvető feltétele, a szabályok követése, normák tiszteletben tartása az együttmüködéshez szükséges magatartás, amelynek nincs mindig közvetlenül mérhető haszna. Az együttműködő, társadalom érdekét szem előtt tartó viselkedést proszociális viselkedésnek nevezzük.

Ugyanakkor a szabályszegés közvetlen haszna jelentős motivációt jelenthet a csalásra, potyázásra, egyéb, a közösség érdekeinek ellentmondó viselkedésre. Ebből a szempontból minden nem önérdekkövető magatartás altruistának (áldozatkész, önzetlen) tekinthetö.

A tisztán önérdekkövető magatartás esetében a szabályszegő magatartást az egyének a kimenetek várható értékének függvényében értékelik, és valósítják meg, függetlenül annak a közösségre gyakorolt hatásáról, beleértve az elkövető pozícióját is. Ekkor a szabálykövetés kizárólag a közgazdasági ösztönzők mértékétől függ, tehát a keretrendszer azt feltételezi, hogy megfelelő büntetések nélkül a szabályok nem lennének betartva, mindenki „gazfickónak" tekinthető. A tisztán altruista magatartás esetén tökéletes szabálykövetés valósul meg, amennyiben a szabályok a közösség érdekét mozdítják elő. (Bowles, 2018)

A tökéletes altruizmus és a tökéletes önérdekkövetés tiszta formában általában nem jellemzők. Bár a személyiségjegyek alapján az egyének altruista, individualista attitűdje mérhető, azonban mégis számos tényező befolyásolja, hogy az egyén egyes szituációkban milyen döntést hoz, melyik magatartást követi inkább. (Bereczkei, 2009)

A fejezet elsőként bemutatja az önérdekkövető és altruista magatartások modelljét, majd a tisztán önérdekkövető magatartás esetén a szabálykövetés és szabályszegés közti választás mechanizmusát. Ezt követően ismerteti azokat a területeket és tényezőket, amelyek esetében a kilátáselmélet igazolta az önérdekkövető magatartás hiányát. Harmadikként a fejezet az eredeti tőkefelhalmozás példáján keresztül mutatja be azt, hogy az intézményrendszer megváltozása miként eredményezheti a szabályszegő magatartás széleskörü elterjedését. Végül Weber protestáns szekták müködését leíró példája alapján azt mutatom be, hogy a csoportba tartozás a tisztességes magatartás szignálozására is alkalmas lehet.

A fejezet nagymértékben támaszkodik a 2017-ben megjelent, az elméleti irodalmat áttekintő tanulmányomra. (Ritzlné Kazimir, 2017) 


\subsubsection{Az altruista és individualista magatartás modellje}

Az egyén individualista, önérdekkövető magatartásának kialakulása könnyen érthető, hiszen az önérdekkövetés a túlélés záloga, evolúciós szemléletben az önérdekkövető egyedek fennmaradása és így ennek a magatartásnak a továbbörökítése valószínűsíthető. Ezért meglepő első pillantásra, hogy a proszociális viselkedésformák kiterjedt skálája a törzsi társadalmaktól kezdve a modern társadalmakig mégis mindenhol előfordul.

A szociálpszichológia az altruista viselkedés különböző formáit különbözteti meg attól függően, hogy az kik felé irányul, és milyen haszonnal jár a döntéshozóra nézve. Az első fontos formája az altruista magatartásnak a rokonszelekció. Ez a magatartásforma az állatvilágban is megfigyelhető, a rokonokkal szembeni önzetlen és támogató viselkedést jelenti. Az emberek a rokonaikkal szemben nagylelküek függetlenül a személyiségjegyeiktől és a személyes kapcsolat szorosságától. Ez a jelenség szintén evolúciós folyamatokkal igazolható. (Bereczkei, 2009)

A nem rokonokkal szembeni legegyszerübb altruista magatartás az altruista reciprocitás, ekkor az egyén látszólag önzetlen cselekedetének motivációja a szívesség, segítség, ajándék későbbi viszonzásának elvárása. Az ajándékok, segítségek, szívességek rendszere számos ősi társadalmat átszőtte, segítségével a csoporton belüli és a csoportok közti stabilitást, javakkal való megfelelő ellátottságát biztosították. (Bereczkei, 2009) A reciprocitás nem szerződés a szó mai értelmében, nem piaci csere, a viszonosság megkövetelésére nem állnak rendelkezésre normatív eszközök. Azonban a reciprocitás rendszerébe való beilleszkedés a csoporton belüli hierarchiában való kedvező elhelyezkedés, a státusz és a reputáció feltétele.

A reciprocitás az empirikus gazdaság része, habár ez nem piaci integrációs forma, és nem az ármechanizmus az elosztás alapja. (Polányi, 2004) (Polányi, 1976)

Az empirikus gazdaság „az ember és a környezet közti kölcsönhatás intézményesített folyamata, amely a szükségletkielégítő anyagi eszközökkel való folyamatos ellátást biztosítja." (Polányi, 1976, old.: 236) Az intézményesülés módját az határozza meg, ahogy a gazdaság részei egymással kölcsönhatásba lépnek és a részek újratermelődnek. Az integráció, vagyis intézményesülés módja Polányi szerint alapvetően háromféle lehet, ezek a reciprocitás, redisztribúció és a piaci koordináció. Különböző korokban és társadalmakban az integrációs formák eltérő súllyal voltak jelen. 
Az ajándékozás kiterjedt rendszere számos társadalomban megfigyelhető, ahol nem döntő fontosságú a piaci koordináció. Az észak-amerikai indián törzsek, a polinéziai és melanéziai népcsoportok közti formális ajándékozási rítusok vagy akár a közép-európai falusi közösségekben az ajándékozási, ünneplési hagyományok mind erre bizonyítékok. Az ajándék elfogadása lekötelezettségi viszonyt alakít ki, viszonzási kötelezettséget jelent. Azonban ez nem csupán egyszerüen tárgyak vagy pénznek tekinthető dolgok cseréje, hanem úgy müködik, mintha az ajándékozó magából adna egy részt az ajándékozottnak. Emiatt az ajándékok általában nagyra becsült, értékes dolgok mindkét fél számára. Az ajándékozási folyamatban a hangsúlyozott nagylelküség rendkívül fontos tényező.

A megajándékozott tartozik az ajándékozónak. Amennyiben az ajándékot a közösség szabályai szerint (határidő, alkalom, ajándék nagysága, összetétele) nem viszonozza, elveszti becsületét. Az ajándékok sokszor valamilyen gazdasági eseményhez köthetők, például házépítés, temetés körüli teendők. Így az ajándékokat munkáért is adhatják. ${ }^{2}$ (Mauss, 2000) A viszonzott szívességek rendszere, a „munkacsere”, vagy a zsebbe fizetett bér alkalmi jellegű munkáért hasonló jelenségek. Ezek egy része azonban már az adócsalás kategóriába tartoznak a modern jogrend szerint. (Williams, 2004)

A redisztribúció valamilyen hierarchikus kapcsolaton alapul. Bizonyos javak esetében a redisztribúció elengedhetetlen, ezért ez az integrációs forma általában a legtöbb társadalomban megtalálható, ez az újraelosztás alapja. A piaci koordináció kialakulásának feltétele a munka, pénz és árupiac együttes jelenléte.

Megfelelő intézmények jelenléte szükséges az integrációk létrejöttéhez, a szimmetrikus csoportok nélkül nem müködik a reciprocitás, az áru-, pénz- és munkapiac nélkül a piaci koordináció. Sőt, a piaci koordináció kialakulása a reciprocitás jelentős gyengülésével vagy megszünésével jár együtt, hiszen a részvétel a munkapiacon korlátozza a reciprocitás lehetőségét, az árupiacon pedig beszerezhetők a reciprocitás keretében nyújtott javak.

\footnotetext{
${ }^{2} \mathrm{Az}$ ajándékozási rendszer a jogrend része a megfigyelt társadalmakban, habár ez nem formális, írott jogszabályokat jelent. Az ajándék egyfajta szerződés. Mauss felhívja a figyelmet arra, hogy amennyiben a gazdasági folyamatok vizsgálatát kizárólag a piaci alapú, önérdekkövető tranzakciókra szükítjük le, és kihagyjuk ezeket a tradicionális, véleménye szerint a piaci alkudozásnál magasabb rendủ és a kultúrában mélyen gyökerező szokásokat, akkor jelentősen leszükítjük és szegényesebbé tesszük világról alkotott képünket.
} 
A reciprocitás és a rokonszelekció körébe tartozó magatartásformák tehát nem illeszthetők a piaci mechanizmus keretrendszerébe, az ilyen jellegü tranzakciók egy része a modern társadalmakban a korrupció, uram-bátyám kapcsolatok körébe tartozik, és sokszor illegális.

Az együttmüködés szempontjából az altruista büntetésnek (Bereczkeinél erős altruista reciprocitás a jelenség elnevezése) jelentős szerepe van. Amennyiben egy csoportban valamelyik csoporttag csal vagy nem együttmüködő, akkor az együttmüködő csoporttagok egy része hajlandó megbüntetni még akkor is, ha a büntetés önmagának is kárt okoz. A nem büntető, együttmüködő csoporttagok ekkor összességében jobban járnak, hiszen a büntetés növeli a kooperálás szintjét, és így a csoport által realizált hasznot.

A büntetés egyik formája az indirekt agresszió, ilyen a pletyka, ami a nem együttműködő csoporttag státuszának csökkentésére irányul. (Bereczkei, 2009)

Az altruista büntetés az egyéni szelekció egyik formája, szerepét a csoportszelekció esetében a normarendszer tölti be. A norma több, mint személyes érzelem, olyan személyes standardok foglal magába, amelyek valamilyen közösen elfogadott vélekedésen alapulnak, a csoporton belüli elvárt viselkedést szabályozzák. A normák feltérképezése nélkül lehetetlen egy közösség életéről és müködéséről megfelelő képet alkotni. A normák kikényszerítésére a közösségen belül több altruista büntetést alkalmazó személy együttes müködésére van szükség, ami a csoportérdek és az önérdek közötti átkapcsolás lehetőségét tételezi fel. (Bereczkei, 2009)

A büntetés mellett a reputációt kell még megemlíteni együttmüködésre motiváló tényezőként. Az indirekt reciprocitás (vagyis közvetett kölcsönösség) magyarázatául szolgálhat, hogy a viszonzás nélküli szívességek, ajándékok az ajándékozó státuszát növelik a csoporton belül. Az ilyen tranzakciók kifejezik, hogy az ajándékozó megengedheti magának a nagylelküséget. (Bereczkei, 2009)

Bár látszólag az altruizmus eddig bemutatott formái végső soron szintén az önérdekkövetés formáinak tekinthetők, azonban az eredmény vagy hozam általában csak bizonyos idő elteltével jelentkezik. További különbség, hogy esetükben az egyén csoporton belüli pozíciója szintén fontossá válik, hiszen ez jövőbeli előnyök forrása lehet. 
Kérdés, hogy létezik-e egyáltalán olyan altruizmus, amelynél az önérdek teljesen kizárható. Ilyen az empátián alapuló altruista magatartás, amikor a motiváció a másik emberre irányuló érzelmi állapot, a szenvedő ember fájdalmára való ráhangolódást jelenti. (Bereczkei, 2009)

A fentiekből látható, hogy az egyén magatartása az önérdekkövető és empátián alapuló altruista magatartás között széles skálán helyezkedhet el. Az egyén döntése az adott helyzetben nem elöre determinált, hanem számtalan tényező kölcsönös egymásra hatásával alakul ki. A döntésre ható tényezők kölcsönhatásait mutatja be a következő 7 . ábra.

7. ábra: A proszociális tevékenység kialakulására ható tényezők egyszerüsített modellje

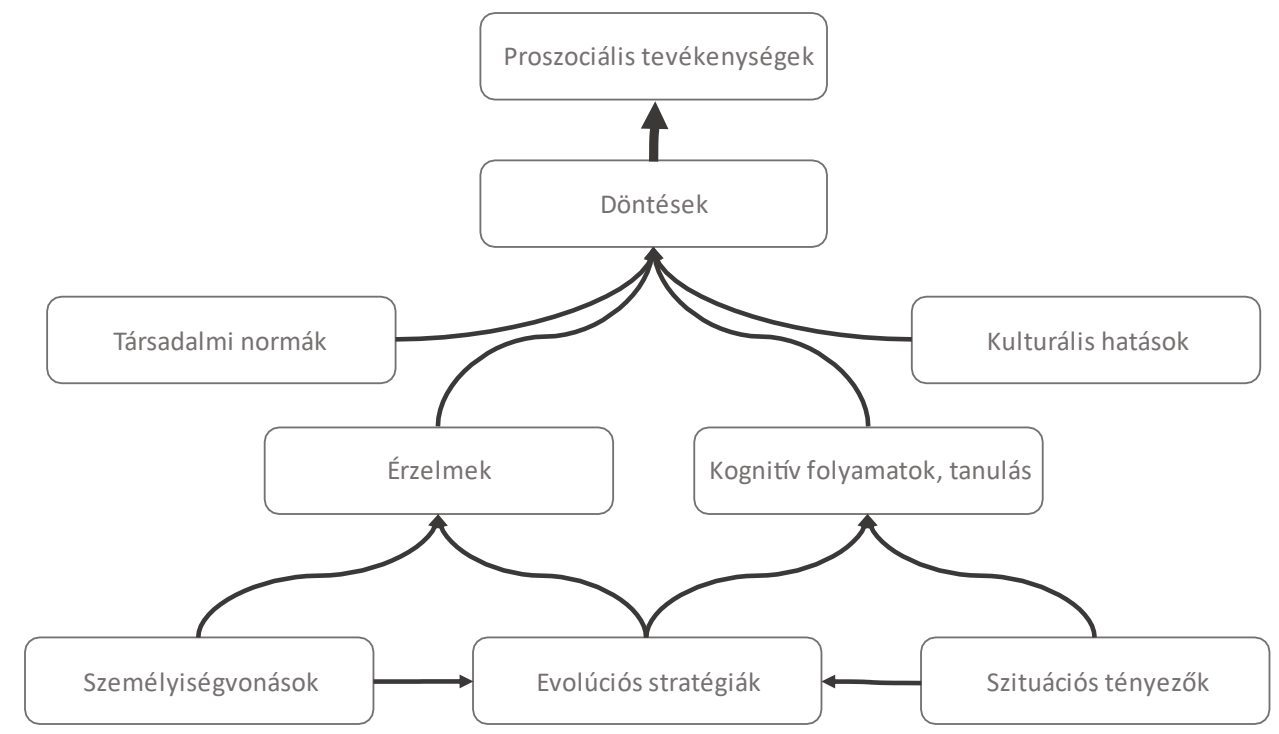

Forrás: Saját szerkesztés, (Bereczkei, 2009, old.: 254.)

Az evolúciós stratégiák (önérdekkövetés, rokonszelekció és reciprocitás) kombinációjára hatnak a személyiségvonások, amelyek jelentős részben, 40-60\%-ban örökletesek. A szituációs tényezők is befolyásolják a döntéseket, ilyen lehet az idő. Ha például sietnünk kell valahová, akkor hajlamosabbak vagyunk az altruista szempontokat félretenni.

A döntéseket az érzelmek is befolyásolják. A csalókkal szembeni düh, a társadalommal szembeni bizalom egyaránt hatással lehet az együttmüködési készségünkre vagy az 
altruista büntetés alkalmazására. Emellett a kognitív folyamatok (tanulás, optimalizálási kalkulációk) is hatással vannak a döntéseinkre. Végül a kulturális hatások és a társadalmi normák teszik nyilvánvalóvá számunkra, hogy az adott helyzetben hogyan lenne tanácsos döntenünk. (Bereczkei, 2009)

\subsubsection{Az adócsalás a mikroökonómia szempontjából}

A közgazdaságtudomány nézőpontjából a szabályszegő magatartás - beleértve a csalást is - az egyén hasznosságmaximalizáló döntéséből kiindulva a többszereplős döntési helyzeteken keresztül a piaci szerkezetre és a hatékonyságra gyakorolt hatásáig különböző perspektívából vizsgálható.

Az egyén számára a csalás bizonytalan kimenetelü tevékenység, ahol számolni kell a felderítés valószínűségével és az ezzel járó szankciókkal is. A modell ezért a várható hasznosság elméletére épít. A várható kimenet értékelésének a szempontjából a döntéshozó kockázatkerülő vagy kockázatkedvelő lehet. Amennyiben a vagyon pótlólagos növekedése a hasznosságot csökkenő mértékben növeli, az egyén kockázatkerülőnek tekinthető, hiszen ekkor a csaló tevékenység várható értéke, figyelembe véve a felderítés valószínűségét és a büntetést alacsonyabb hasznosságot jelent a csalás nélküli kiinduló állapothoz képest. Másként megfogalmazva a kockázatkerülő magatartás azt jelenti, hogy az egyén számára kevesebb ér az egységnyi vagyon növekedés, mint a vagyon egységnyi csökkenése miatt realizált hasznosság veszteség. (Von Neumann \& Morgenstern, 1944) Kockázatkerülő döntéshozó esetén a vagyon növekedésének csökkenő a határhaszna, számára tehát szerencsejátékban vagy akár adócsalásban részt venni nem racionális döntés. (Mas-Collel \& Whinston, 1995)

Allingham és Sandmo felhívta a figyelmet arra, hogy a kockázatkerülő vagy kockázatkedvelő attitűd nem állandó, alacsony jövedelem mellett a döntéshozók inkább kockázatkerülők, magasabb jövedelemnél kockázatkedvelők. Ez a büntetések meghatározása miatt fontos, hiszen előfordulhat olyan adókulcs és büntetés kombináció, amely akkora lehetséges nyereséggel jár, ami a jövedelmet a kockázatkedvelő tartományba növeli, ekkor az amúgy kockázatkerülő döntéshozó is csalóvá válik. (Allingham \& Sandmo, 1972)

A várható hasznosság elméletén alapul Becker modellje a bűncselekmények társadalmi optimumának vizsgálatáról. Modelljében ezért a bünelkövetés közvetlen költségein túl a társadalomnak okozott közvetett költségei is számításba veszi. 
A közvetlen költség megegyezik az elkövetés által okozott kár és nyereség különbségével. Az elkövetés közvetett költségei a megelőzés, felderítés (rendőrség), bíróságok működtetésének költsége, továbbá a büntetés végrehajtás és a rehabilitáció ráfordításait tartalmazzák. A közvetett költségek az igazságszolgáltatási, felderítési rendszerben felhasznált inputok mennyiségétől függenek adott technológia mellett.

A felderítési valószínűség és büntetés nagyságának növekedése egyaránt csökkenti az elkövetett illegális tevékenységek számát, azonban nem egyforma mértékben. Kockázatkedvelő döntéshozó esetében a felderítés valószínűségének nagyobb a hatása az elkövetések számára, kockázatkerülő szereplő nem is jelenik meg az illegális tevékenységek ,piacán”.

Az elmúlt évszázadok folyamatai is alátámasztják a felderítés valószínüségének jelentős hatását, a felderítések valószínűségének javulása mellett a büntetések súlyossága folyamatosan csökkent. A kettő közti tradeoff kihasználásával javult a hatékonyság.

A lehetséges büntetések közül Becker modelljében kizárólag a pénzbüntetésnek van értelme, hiszen ez az egyetlen, amely kárpótolja az áldozatot, és minimális társadalmi többletköltséggel jár. A modell tanulsága, hogy a bünözés problémájának társadalmi kezelésében létezik hatékony megoldás, amely nem vezet az erőforrások túlzott felhasználásához. Arra is felhívja a figyelmet, hogy a piac müködése itt is eredményes lehet, amennyiben a törvényhozók felismerik az ösztönzők kombinálásában rejlő lehetőségeket. (Becker G. , 1974)

Allingham és Sandmo az adócsalással kapcsolatban felhívta a figyelmet arra, hogy az adóellenőrzések valószínüségét az adózók bevallott adatai is meghatározzák. Amennyiben az adózó a foglalkozására jellemző átlagnál kevesebb jövedelmet szerepeltet adóbevallásában, akkor felkeltheti az adóhatóság figyelmét. Továbbá, ha az adózó számol a jövőben potenciálisan bekövetkező adóellenőrzéssel, és az adóellenőrzés az összes múltbéli időszakra kiterjed, akkor az adózó növeli a bevallott jövedelemét, és csökken az eltitkolt jövedelme. (Allingham \& Sandmo, 1972)

A jövedelemadó csalást az adószabályok bonyolultsága is befolyásolhatja, hiszen növeli az adózás költségét a szabályok követése és betartása. Erre jó példa az ingóságértékesítés hazai gyakorlata. Az elmúlt időszakban jelentősen megnőtt a használtcikk piacok, online felületek népszerüsége. Az eladók között a fölöslegessé vált termékeiket értékesítő magánszemélyek ugyanúgy előfordulnak, mint azok, akik számára ez megélhetési forrást 
jelent. A bevétel után adózniuk kell azoknak, akik a tevékenységet üzletszerüen végzik. A nem üzletszerü eladóknak csak akkor kell adót fizetniük (leegyszerüsítve), ha az értékesítésből jövedelmet szereztek, vagyis a jószágot a piaci árnál vagy a beszerzési árnál drágábban adták el (a felújítási, javítási költségeket is figyelembe véve). ${ }^{3}$ A szereplők beazonosítása és a körülmények vizsgálata az adóhatóság számára valószínüleg nem éri meg (viszonylag kisértékü tranzakciók ellenőrzése időigényes, ugyanakkor kevés adóbevételt eredményez). (Szücs, 2013) Ezért racionális viselkedés lehet a használtcikkek értékesítése esetén az adócsalás.

Az adócsalás elemzésének másik aspektusa az adó és a közjavak kapcsolata. Az adózó személyesen az adóért közvetlenül és beazonosíthatóan nem realizál semmilyen juttatást, az a közjavak ellenértékének tekinthetö, amelyek a legtágabb értelemben vett közszolgáltatásokat is magukban foglalhatják. Az adózó nem tudja, hogy pénzéért cserében milyen minőségü közszolgáltatásban részesül, csak valamilyen szubjektív valószínűség alapján tudja megítélni ennek várható értékét. Információs aszimmetria lép fel, és az adózó annak megfelelőn határozhatja meg az adóját, hogy számára a rossz minőségü közszolgáltatás mennyit ér. Ennek kontraszelekció lehet a következménye, vagyis az adózók annyira csökkenthetik hozzájárulásukat a közjavak kínálatához, ami azok minőségét rontja vagy ellátását akadályozhatja. (Akerlof G. , 1970)

Amennyiben figyelembe vesszük a többi szereplő döntéseinek hatását is az egyén választására, akkor az adócsalást játékelméleti kontextusban érdemes vizsgálni. Az adócsalónak figyelembe kell vennie az ellenőrző hatóság várható magatartását, és a többi potenciális adócsaló stratégiáját is. Így az elkövetés haszna függ attól, hogy összességében mennyien döntenek az adócsalás mellett, másrészt attól is, hogy a hatóság mekkora valószínüséggel deríti fel az adócsalást. A Szántó és Tóth által ismertetett játékelméleti modell szerint az egyensúly a kevert stratégiák halmazán alakul ki (bizonyos fix gyakorisággal játszik egyik és fix gyakorisággal másik stratégiát a szereplö). Az adócsalás valószínűsége ekkor nem függ a büntetés nagyságától, csak a felderítés valószínűségétől. (Szántó \& Tóth, 2001)

Ezt az eredményt támasztja alá Fazekas vizsgálata is. Ha az adócsaló a csalással csökkenteni tudja a termelés határköltségét, versenyelönyt érhet el, ami a versenytársakat

\footnotetext{
${ }^{3}$ Az 1995. évi CXVII. törvény a személyi jövedelemadóról 11. § (3) alapján a magánszemélynek nem kell bevallania a bevétel, ha annak éves összege nem haladja meg a 600 ezer forintot, vagy az abból megállapított összes jövedelem nem haladja meg a 200 ezer forintot.
} 
is hasonló magatartásra késztetheti. Egy tökéletes versenyhez közeli piaci helyzetben a nem adócsalók kiszorulását okozhatja a piacról az elterjedt adócsalás. (Fazekas, 2009) Másrészről, ha egy piacon nagyobb vállalat jelenik meg, akkor a vállalat versenytársai, beszállítói vagy vásárlói nem azonos mértékben csökkentik adócsaló tevékenységüket. (Szabó, Gulyás, \& Tóth, 2009)

\subsubsection{Etika, bizalom és a csalás}

A mikroökonómiai modellek szerint az egyén preferenciái és az intézményi környezet figyelembevételével optimalizálja szabályszegő magatartását, ez egyúttal azt is jelenti, hogy az ösztönzők megfelelő megválasztásával a társadalmi hatékonyság javítható. . Az önérdeken alapuló megközelítés azt feltételezi, hogy mindenki potenciális gazfickó, és a szabályok kellő szintű betartásában csak akkor bízhatunk, ha megfelelő büntetési és felderítési rendszert üzemeltetünk. Ez a hozzáállás megkérdőjelezi a gazdasági szereplők megbízhatóságát. Ugyanakkor a valóság nem így müködik, a gazdasági tranzakciókra a résztvevőkbe vetett kölcsönös bizalom valamilyen szintje jellemző.

A társadalmat, ahogy Az altruista és individualista magatartás modellje című alfejezetben kifejtettem, az együttmüködés különböző szintjeinek és formáinak változatos egyvelege jellemzi. Ezért az önérdekkövetést feltételező ösztönzési rendszerek bevezetése nem várt eredménnyel járhat. Egy társadalmi jelenség mögött lévő egyéni vagy csoportszelekciós mechanizmusok (altruista magatartásformák vagy társadalmi normák) sérülhetnek, ha az ösztönzőkkel (adókkal és támogatásokkal) árrendszert vezet be a kormányzat az adott területen és így a jelenséget a piaci integráció körébe vonja. Előfordulhat, hogy ekkor az egyének attitűdje elveszíti a korábbi reciprocitáson alapuló vagy egyéb proszociális jellegét, és a bevezetett ösztönző a kormányzat által remélt eredményhez képest alacsonyabb hatékonysággal fog müködni. Bowles ezt nevezte kiszorítási hatásnak. A gazdaságpolitikának ezért a kívánt cél eléréséhez a gazdasági ösztönzők és morális célok megfelelő kombinálására kell törekednie. (Bowles, 2018)

A piacok tökéletes müködését célul kitüző kormányzat gyengíti a társadalmi normákat a kiszorítási hatás miatt, és szélsőséges esetben akár a piacgazdaság müködéséhez szükséges normarendszert is károsíthatja. Viszont a társadalmi normákat támogató intézmények általában akadályozzák a piacok müködését a reciprocitás erősítésén keresztül. 
A reciprocitás és a piac hatékony müködése között tradoff feltételezhető, és ebből arra következtethetnénk, hogy a fejlett piacgazdasággal rendelkező országokban a társadalmi normák szerepe csekély. Azonban a valóság ezt a feltételezést nem támasztja alá. A megfelelő normarendszer és a fejlett piacgazdaság együttes jelenléte több okra vezethető vissza. Egyrészt a stabil piaci kapcsolatok jelenléte, az idegenekkel kötött üzletek nyereségessége garantálja a piacgazdaságba vetett bizalmat, másrészt az állam azon törekvése biztosítja a normák és a piaci integráció együttes magas szintü jelenlétét, amellyel gyengíti a rokonszelekció jelenségét. (Bowles, 2018)

Az együttmüködés és a társadalmi normák fontosságát hangsúlyozza Fukuyama is a Bizalom című mủvében. A bizalom forrása a társadalmi tőke, ami az emberek együttműködési képessége, lehetővé teszi a közös munkát és a közös célok elérését. A bizalom a közös normák alapján elvárt becsületes viselkedés. A bizalomhoz szükséges a megfelelő normarendszer, amelyet a szocializáció során sajátítunk el. A bizalom három területét lehet megkülönböztetni: a rokonokkal, közeli barátokkal szembeni bizalom, az ismeretlenekkel szembeni bizalom és az állammal szembeni bizalom.

A magas szintü bizalom és társadalmi tőke a gazdasági és társadalmi elönyök széles skálájával jár együtt. Az ilyen társadalmak például hatékonyabb termeléssel, nagyobb gazdasági növekedéssel, és a szabályszegő magatartás alacsonyabb szintjével jellemezhetők. (Fukuyama, 2007)

A társadalmi tőke kialakulása jelentős időt vesz igénybe, nehézkesen változik, a jelentős események akár több évszázadon keresztül is hatást gyakorolhatnak a szintjére. (Fukuyama, 2007) A bizalom és a bizalmatlanság a gazdasági tranzakciókon keresztül pozitív ill. negatív multiplikátorként müködik. (Akerlof \& Shiller, 2009)

A szabályszegő magatartással kapcsolatban az államba vetett bizalom és a család, baráti kör iránti bizalom fontos. Az államba vetett bizalom jelentős csökkenése a család és szűkebb közösség iránti bizalom megerősödésével jár együtt, és ekkor a különböző szabályszegő magatartási formák elterjedté válhatnak. A család felé irányuló magas fokú bizalom a családon belül feltétlenné válik, de kifelé gyanakvóvá tehet, és meggátolhatja az idegenekkel szembeni megfelelő kapcsolat kialakítását, és a hatékonyságnövekedés, ill. a gazdasági fejlődés gátjává válhat. Dél-Olaszországban például az állammal szembeni bizalom és a gazdasági teljesítmény egyaránt alacsony, a maffia a társadalomba és a gazdaságba is mélyen integrálódott. (Fukuyama, 2007) 
Fukuyama által felvázolt modellt az Egyesült Államok, Kína, Japán, Németország, Franciaország és Olaszország esetén mutatta be.

A TÁRKI kutatása a magyarországi normarendszer és bizalomhiány feltérképzésére irányult. A bizalom szempontjából a magyar társadalom általános bizalmi szintje a nyugat-európainál alacsonyabb. Az általános bizalomnál az intézményi bizalom lényegesen alacsonyabb, míg az idegenekbe vetett bizalom magasabb a többi középkelet-európai országhoz képest. A magyar gazdaság alacsony bizalmi helyzetének gazdasági költségei jelentősek. Ilyen a jogi procedúrák bonyolultsága, a készpénzes előlegezés magas aránya és az alacsonyabb hazai vállalatméret. (Tóth I. G., 2009) Az állammal szembeni bizalom szempontjából a magyar társadalom - hasonlóan a többi kelet európai társadalomhoz - az államhoz ambivalensen viszonyul. Egyrészt gyanakvó az állammal szemben, másrészt az alapvető gondoskodást elvárja a kormányzattól. Ez az attitüd a szocializmus alatt alakult ki, azonban a rendszerváltás után is fennmaradt. A rendszerváltás utáni folyamatok nem segítették elő a kormányzat iránti bizalom növekedését, amennyiben a társadalom úgy érezte, hogy magára hagyták, és a kormányzat nem tesz meg szükséges intézkedéseket. (Sugár \& Trautmann, 1995)

A normakövető magatartás vonatkozásában a magyar társadalom engedékenyebb a normaszegéssel szemben a környező országokhoz képest. Továbbá az adócsalás társadalmi megítélése a környező országokhoz képest jóval megengedőbb, ugyanakkor rendszerváltáskor mért értékhez képest polarizálódott. (Tóth I. G., 2009)

A kilátáselmélet szintén a mikroökonómia eredményeire reflektál, amikor ellenőrzött, kísérleti körülmények között vizsgálja meg a modellek müködését. Mazar és szerzőtársainak kísérletei igazolták, hogy a felderítés valószínüsége és a várható kifizetés nem befolyásolja a csalás átlagos szintjét, a döntéshozók nem racionálisak. (Mazar, Amir, \& Ariely, 2008) Az irracionalitás több tényezőnek köszönhető, ezek a proszociális, altruista viselkedés, a kognitív torzítás (gondolkodási hiba), az információs aszimmetria és a személyiségjegyek.

Kahneman agyunk müködésében két fiktív rendszert különböztet meg. Az első rendszer feladata a gyors gondolkodás, a másodiké a racionális, nagy energiabefektetést igénylő gondolkodás. A rendszerek szorosan együttmüködnek, az első rendszer sok beidegződéssel és előítélettel rendelkezik, ezzel sok energiát és időt takarít meg a döntési szituációkban, ugyanakkor a problémák rövidre zárása miatt több tévedést követhet el. 
Ha a második rendszer müködéséhez nincs elég idő vagy energia, akkor az első rendszer veszi át a vezető szerepet. (Kahneman, 2013)

A tényezőket, amelyek a racionális magatartást befolyásolják és így csalás esetén a mikroökonómiai modellnek ellentmondó eredményre vezetnek, a következő, 8. ábra mutatja be.

8. ábra: A kilátáselmélet szerint a csalást befolyásoló tényezök

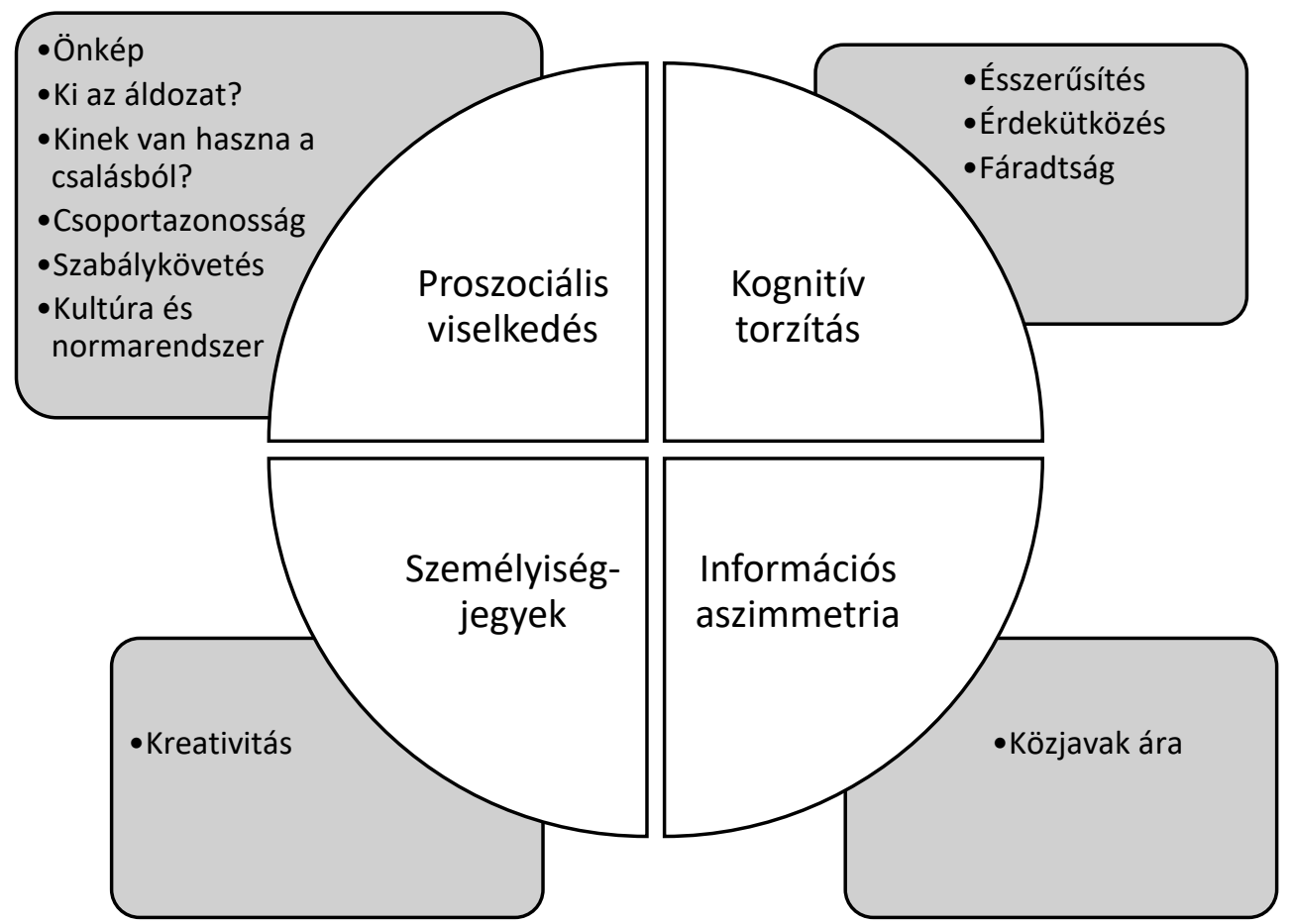

Forrás: Saját szerkesztés (Ariely, 2015), (Hasseldine \& Bebbington, 1991) és (Mazar, Amir, \& Ariely, 2008) alapján

A kilátáselmélet igazolta, hogy a pozitív énkép és a szabálykövető magatartás csökkenti a csalásra való hajlandóságot. (Mazar, Amir, \& Ariely, 2008) (Hámori, 2003) A csoporttal való azonosulás is jellemzően befolyásolja az adózói magatartást. Ha az adózó környezetében több adócsaló van, akkor ő is hajlamosabb lesz adócsalást elkövetni. (Hasseldine \& Bebbington, 1991) Ugyanakkor a rivális szereplők nyilvános csalása relatíve csökkenti a csalás szintjét azért, mert ezzel is elhatárolódhatnak az egyének a riválisaiktól. Továbbá növeli a csalás valószínüségét, ha másoknak előnye származik a mi csalásunkból, de csökkenti a csalás esélyét, ha a csalás olyan kárára történik, akinek a helyzetével kifejezetten erkölcstelen visszaélni (fogyatékkal élők, gyermekek). (Ariely, 2015) 
A kultúra és normarendszer szerepének vizsgálata a kilátáselmélet eszköztárával azt elemezte, hogy a nemzetek között létezik-e különbség a csalással kapcsolatos attitüdökben. Kultúra-független kísérletek eredménye szerint a csalás szintjében a vizsgált nemzetek képviselői között nincsenek szignifikáns különbségek. Vannak azonban olyan, az egyes országokra jellemző szituációk, amelyekben a résztvevők tradicionálisan csalni fognak. Továbbá az erkölcsi szabályokra való folyamatos emlékeztetés csökkenti a csalást. Az emlékeztetés történhet egy egyszerü nyilatkozat aláírásával is, de a különböző vallási rituálék is ezt a célt szolgálják. (Mazar, Amir, \& Ariely, 2008), (Ariely, 2015)

A döntéshozók magatartása nem állandó és sokszor nem racionális, mert döntéseik során a rövidebb utat követik, és döntésük függ a probléma megfogalmazásától is (kognitív torzítás). (Kahneman \& Tversky, 1979) A pénztől távolabb lévő dolgok eltulajdonítása könnyebben indokolható (racionalizálás) személyes szükséglettel, ezért ezek esetében a csalás valószínübb. Az érdekütközés esetén a döntéshozó több, egymásnak ellentmondó motivációval is rendelkezik. A lekötelezettség vagy az anyagi érdekeltség a döntéshozót még akkor is befolyásolja, ha tudatosan igyekszik megőrizni az objektivitását. (Tipikus példa erre az orvoslátogatók szerepe az egészségügyben.) A kimerültség szintén befolyásolja a csalás szintjét, a fáradtság aláássa a döntéshozók erkölcsi tartását, és az első erkölcsi megingás után a többi csaló döntés valószínüsége jelentősen megnő. (Ariely, 2015)

Hasseldine és Bebbington szerint az adózók úgy vélik, az adó ellenében részesülnek közjavakban, és ha ezt a „cserét” egyenlőtlennek ítélik meg, akkor hajlamosabbak az adócsalásra (ez a magatartás főként a magasabb jövedelmü adózók esetében figyelhető meg). Az adócsalás a legtöbb adózó esetében áldozat nélküli büncselekménynek minősül, például a szereplök ezt kevésbé súlyos büncselekménynek tartják, mint a kerékpárlopást. (Hasseldine \& Bebbington, 1991) A kreativitás, amely a személyiségjegyek közé tartozik, a kognitív gondolkodás magasabb szintjével jár együtt és szintén nagyobb csalási hajlandóságot jelent. (Mazar, Amir, \& Ariely, 2008)

\subsubsection{Történeti megközelítés}

Az illegális és legális tevékenységek elkülönítése a történelem során nem egyértelmü. Bizonyos időszakokban egyes tevékenységek kifejezetten támogatottak, míg más korszakokban szigorú büntetést vontak maguk után. Ilyen például a gyilkosság, amely 
általában tilos, háborúban azonban hazafias tett. A tisztességes ember csak elméletben létezik, morálisan senki sem fedhetetlen. Bernard Mandeville „A méhek meséje” címü, nagy vihart kavart, elsőként 1705-ben megjelent szatirikus verses müve különítette el a magánvétek és a közbün fogalmát. A magánvétek megengedett, a közbűn törvénnyel tiltott. (Mandeville, 2004) A közbünnel ellentétben a magánvétek a társadalmi jólétet növeli. A két fogalom közti önkényes határvonal választja el egymástól a bünözőket és a társadalom tisztességes részét. A kormányzat pedig manipulálja az egyéneket annak érdekében, hogy a szabályok folyamatos változását elfogadják, és a kívánt magatartásformák megvalósuljanak.

Nézete szerint az embereket különböző vágyak vezérlik, ezek felváltva irányítják az emberek tevékenységeit. Mandeville sorra veszi a magánvétkeket, és mindegyikről bebizonyítja, hogy a társadalom jóléte irányába hat. Például a hiúság, fényüzés és pazarlás újabb megrendeléssel látja el az iparcikkek termelöit. A fösvény ellenben nem tesz jót, amikor megtakarításait növeli, hiszen így a fogyasztást és a keresletet csökkenti. Ebből a szempontból a rablás is kedvező hatású, mert a fogyasztásból kivont javakat visszajuttatja a forgalomba. A prostitúció is hasznos, hiszen az intézmény alapvetően megvédi a nem prostituált nőket. Hivatalosan tilos a prostitúció a korabeli Angliában, azonban Mandeville szerint az államnak minden eszköze megvan, hogy ezt a tevékenységet ténylegesen megszüntesse, tehát a tevékenység eltürése szándékos.

A méhek meséje Adam Smith A nemzetek gazdagsága (1776) c. müve előtt közel hetven évvel jelent meg, és a mű a korabeli kapitalizmust kritizálja. Számos alapvető közgazdasági összefüggésre hívja fel a figyelmet, mint például a láthatatlan kéz elmélete, vagy a keynesi multiplikátor hatás. Az illegális tevékenységek szempontjából hangsúlyozza, hogy az erkölcstelen tevékenységeknek is lehet jólétet növelö hatásuk, és az, hogy mikor mi illegális és erkölcstelennek minősített, az alapvetően a kormányzat döntésétől függ. Továbbá azt is kiemeli, hogy bizonyos illegális tevékenységek az állam látszólagos tiltása ellenére, a kormányzat hallgatólagos beleegyezésével működnek. A legális és illegális közti határvonal nem egykönnyen meghatározható.

Marx szerint meghatározott szituációkban szintén szükséges az illegális tevékenységek jelenléte, ilyen az eredeti tőkefelhalmozás, és a munkanélküliség esete a piacgazdaságban. A két szituáció azonban nem hasonló abból a szempontból, hogy az eredeti tőkefelhalmozás a kapitalista termelési mód kialakulásának feltétele, egyszeri 
folyamat. Lezárásával egyidejüleg az új termelési mód és felhalmozott tőke legitimációja is megtörténik. Az illegális tevékenységeknek a munkanélküliséggel és válságokkal együtt járó átmeneti fellendülése kontraciklikus, törvényszerü velejárója a kapitalista termelésnek.

$\mathrm{Az}$ eredeti tőkefelhalmozás amiatt tekinthető eredetinek, hogy ez a piacgazdaság kialakulásának folyamata, a müködésének alapfeltételét jelentő tőkés termelési mód keretrendszerének megteremtése, ami a feudális termelés megszünésével kezdődött a XIV. században, és a XIX. században ért véget. Az eredeti tőkefelhalmozás kifejtése a Tőke VII. fejezetében olvasható. (Marx, 1978)

A feudális termelési mód felbomlásával a tőke és a munkaerő szabad termelési tényezőkké vált. A föld koncentrációjának növekedésével együtt valósult meg a mezőgazdaság átállása a növénytermesztésről a juhtenyésztésre, ami megteremtette az ipari forradalom alapjának, a textilipar fejlődésének a feltételeit. A korábbi szabály- és intézményrendszer teljesen megszünt, ami egyfelől felszabadította az embereket korábbi kötelezettségeik alól (például a céhek nehézkes struktúrájától), másfelől viszont a korábbi feudális jogok, és így a megélhetési lehetőségek is megszüntek. Az új, piacgazdaságnak megfelelő szabály- és intézményrendszer kialakulásához időre volt szükség. Az átmeneti időszak - az eredeti tőkefelhalmozás -, vagyis az átalakulás a korábbi gazdasági rendszer felbomlása miatt zürzavarral és problémákkal járt. A felszabaduló munkaerő még nem tudott beilleszkedni az új rendszerbe, mert a munkapiac és vele együtt az árutermelés még nem alakult ki. Amikor a városba áramló tömeg zavaróvá vált, a véres törvényekkel próbáltak rendet tenni. Ekkorra elterjedt a csavargás, vadorzás, koldulás. A munkakínálat alakulását és az integrációt a bérek minimumának meghatározása és a munkások jogainak (gyülekezési jog) korlátozása segítette elő. A munkapiaccal párhuzamosan az árupiac is kialakult, hiszen a városi népesség növekedésével és egyúttal az önellátás lehetetlenné válásával az árupiaci kereslet jelentősen megnő.

Ezek az események mind a korabeli jogrendnek és szokásoknak mondtak ellent, a föld koncentrált tulajdonlásának kialakulása csak illegálisan, a törvényekkel szemben mehetett végbe. A tőkés termelési mód kialakulásához szükséges jelentős tőkemennyiség felhalmozása szintén a szabályrendszer változása miatt eleinte illegális, majd legális folyamatként zajlott le. A vidékről a városokba kerülő emberek illegális tevékenységeket 
végeztek, a munkakereslet növekedésével kerültek át az ipari „tartalékseregek” a legális folyamatokba.

A tőkefelhalmozás erőszakkal ment végbe, ami nagyon sok ember megélhetését lehetetlenné tette, illegális tevékenységekre kényszerítve őket. Az ipari termelési mód kialakulásával a munka iránti kereslet nőtt, és így egyre többen kerültek át a legális munkapiacra, és váltak munkásokká. A két sokaság - az illegális tevékenységekből élők és a munkások - idővel változott, a változás irányát a munkakereslet és a mögötte húzódó árupiaci folyamatok határozták meg.

Az illegális tevékenységek a tőkés termelési módban a rendszer természetes jellemzői, hiszen a piacgazdaság nem tud teljes foglalkoztatást biztosítani. Ez a gazdaság dinamizálásának irányába hat, az adott körülmények között viszonylag kedvező folyamat. $\mathrm{Az}$ illegális tevékenységek eltürése időnként az egész társadalom érdeke, hiszen ez egyfajta hallgatólagos megoldása a legális munka nélkül maradt emberek eltartásának. A munkakereslet növekedésével azonban az emberek legális munkavállalását elősegítve az illegális tevékenységek törvényi visszaszorítására kerülhet sor. Emellett ki kell emelni azt is, hogy kialakuló tőketulajdonos réteg szintén illegálisan jutott a tőkéhez, kihasználva az átalakulással járó zürzavart. (Marx, 1978)

A rendszerváltás időszaka a korábbi termelési mód felbomlásával járt együtt Magyarországon. Kolosi és Szelényi kiemelik, hogy a rendszerváltás után az állami szektor összeomlása a gazdaságot müködésképtelenné tette. Az új gazdasági rendszer kialakítására megvolt a szándék, ám ehhez hiányoztak a források, nem volt megfelelő mennyiségü tőke ahhoz, hogy a vállalkozások létrejöjjenek és müködőképesek legyenek. A korábbi politikai, kapcsolati és kulturális tőke gazdasági tőkére való konvertálása az eredeti tőkefelhalmozás zürzavaros időszakára emlékeztet. (Kolosi \& Szelényi, Hogyan legyünk milliárdosok, 2012) (Bezsenyi, 2015)

A rendszerváltás időszaka a munkapiac átalakulása szempontjából is hasonlított az eredeti tőkefelhalmozás időszakához. A szocialista gazdasági rendszerben teljes foglalkoztatás volt, legalábbis elméletben. A gazdasági rendszer felbomlásával a munkaerő is feleslegessé vált. Ugrásszerüen jelentős munkanélküliség alakult ki, az 1990-es közel 2\%os munkanélküliségi ráta 1992-re közel 10\%-ra, 1993-ra pedig 12,1\%-ra emelkedett. A keresetek és a jövedelmek is jelentősen csökkentek, a reálkereset 1996-ra az 1989-es érték közel 75\%-ára, míg a reáljövedelem a 85\%-ára esett vissza. A nyugdíjak reálértéke még 
ennél is nagyobb mértékben, az 1989-es értéknek kevesebb, mint 70\%-ára csökkent. (KSH, 2010)

A jövedelmi változások a gazdasági szereplök magatartására is hatással voltak. A munkapiaci válság az eredeti tőkefelhalmozáshoz hasonlóan az árupiaci folyamatokat is befolyásolta. (Sik, 1997)

Az intézményrendszer átalakulása során a jelentősen elterjedt csalás, korrupció, bűnözés idővel társadalmi normává válhat, és akár állandósulhat is. Az új intézményrendszer kialakulásával szükségessé válhat az illegális tevékenységek kiküszöbölése a gazdasági folyamatokból. Ezt elősegítheti az amnesztia, és annak a deklarálása, hogy a szabályszegő magatartás ezt követően már nem elfogadott.

Az amnesztia ötlete már többször is felmerült Magyarországon. Például Sárközy Tamás 1996-os cikkében kifejtette, hogy a rendszerváltás során, a gazdasági átalakulással az adóelkerülő, ill. egyéb illegális magatartások a magyar társadalom jelentős részét érintették. A nem megfigyelt gazdaságban való részvétel szinte kényszerként jelent meg. Az ekkor keletkezett vagyon részben, vagy egészben illegális, és sajnos az adóelkerülő magatartás az azóta eltelt évtizedekben sem csökkent a többi, nem posztszocialista ország szintjére. Sárközy véleménye szerint ezeket a felhalmozott vagyonokat egy átfogó intézkedéssel legálissá kellene nyilvánítani, és ezzel a gesztussal lezárni a rendszerváltás átmeneti időszakát. Ez a hirtelen és nagymértékü beavatkozás lehetőséget adna arra, hogy a gazdasági szereplök egyszerre térjenek át a legális, nem adócsaló gyakorlatra. (Sárközy, 1996)

Magyarországon 2013-ban bevezetett és 2017-ig létező stabilitási megtakarítási számla adóamnesztiaként müködött, az offshore cégeken keresztül külföldön csekélyebb adókulccsal adózó jövedelmek hazahozatalára nyújtott lehetőséget. Minimum ötmillió forinttal lehetett a számlát megnyitni, a számlán elhelyezett pénzösszeget a kamatjövedelemre vonatkozó személyi jövedelemadó terhelte. A számlán állampapírban tartották az elhelyezett összeget. Az adókötelezettség a pénz felvételekor keletkezett. Öt év után az adókötelezettség megszünt. A stabilitási megtakarítási számla müködése alatt több mint kétezer magánszemély 156 milliárd forintot legalizált. (VG.hu, 2013.) (hvg.hu, 2017.) Tekintetbe véve, hogy csak az adócsalás miatt nem megfigyelt gazdasági teljesítmény 2002-ben a GDP 9,5, 2005-ben 8,8\%-a volt, ez az összeg valószínúleg 
csekély mértékben járult hozzá a gazdaság fehéredéséhez. (Murai \& Ritzlné Kazimir, 2011)

\subsubsection{A kapesolatok szerepe}

A szociológiai megközelítéshez Max Weber protestáns etikáról szóló magyarázatát tekintem át vázlatosan. A piacgazdaság kialakulásáról Max Weber egyszerübb magyarázatot nyújt, mint Marx. A folyamatnak két, a reformáció által kidolgozott mozgatórugója van. Az egyik az eleve elrendelés, ami szerint az, hogy valaki a kárhozatra vagy üdvösségre jut a halála után, az ember születésekor már meghatározott, az embernek nem áll módjában ezt befolyásolni. A másik tényező, amit Weber kiemel, a hivatás szerepe. A reformáció előtt az emberek mindennapi, világi tevékenységét, szakmáját nem tekintették külön figyelemre érdemes elfoglaltságnak, sőt ezek szükséges rosszként jelentek meg. A két tényező miatt a protestánsok számára a szorgalmasan végzett sok munka normává válik, a pazarlást elkerülik, a vagyonuk szükségszerüen halmozódik, lehetővé téve a kapitalista termelés kialakulását. A magyarázat éles ellentétben áll Marx elméletével, hiszen itt szó sincs erőszakos kisajátításokról, elnyomásról. Azonban Weber is említést tesz az illegális tevékenységek egy köréről, amelyeket egyes csoportok az idegenekkel szemben alkalmaznak. Szerinte minél távolabbi csoportról van szó, annál kevésbé jellemző az erkölcsi normák betartása. Példaként említi a kereskedelmi társaságok tengerentúli tevékenységét.

Ugyanakkor felhívja a figyelmet arra, hogy a gyorsan változó társadalmakban bizonyos fokú zürzavar van jelen. Észak-Amerika példáján mutatja be a jelenséget, ahol a társadalom a tömeges bevándorlás miatt nem volt stabil a XIX. században és a XX. század első felében, európai értelemben vett homogén csoportok nem alakultak ki, a kapcsolatok gyengék voltak.

Ezeket a körülményeket figyelembe véve különösen érdekes Weber protestáns szektákról írt tanulmánya. A szektához tartozás az üzlethez jutás vagy piacra lépés egyik lehetséges, sőt akár szükséges útja volt Észak-Amerikában. Ugyanis a kiválasztottak közé csak az arra méltónak bizonyuló megbízható és erkölcsös emberek juthattak be, a nyilvánosságra kerülő erkölcstelen tettek kizárást vontak maguk után. Tehát aki egy szektához tartozott, az megbízható, becsületes üzletembernek volt tekinthető.

A szekták létszáma ugrásszerüen nőtt a XIX. században. A dinamikusan változó körülmények között nagyfokú információs aszimmetria jelent meg. Nem lehetett tudni, 
hogy ki a megbízható üzletember és ki a szélhámos. A szektához tartozás egyfajta jelzés, garancia, amivel az emberek a tisztességteleneket, csalókat elkerülhetik. (Weber, 1995) A jelenség máig megfigyelhető Észak-Amerikában, amennyiben az egyetemi közösségekhez, klubokhoz tartozás szintén a megbízhatóság jelzésének tekinthető. Magyarországon az egyetemi közösségek tartozás, különös tekintettel a szakkollégiumi tagságokra, szintén egyfajta jelzésként müködik a hallgatók egyetem utáni szakmai életében. (Sik, 2012)

Másik példaként a tisztességes adózás jelzését lehet említeni. 2013-ban nagy vihart kavart az Egyesült Királyságban az ott müködő multinacionális vállalatok társasági adófizetése. Mint napvilágra került, ezek a cégek a leányvállalatok hálózatának, és az ezeken keresztül transzferárazott tranzakcióknak köszönhetően hosszú ideig hatékonyan minimalizálták a társasági adójukat. Az adatok nagy felháborodást keltettek. Ennek hatására 2014-ben alakult a Fair Tax Mark, ami jelzés, a vállalatok a vevőik felé jelzik, hogy transzparens a müködésük, és nem alkalmaznak tisztességtelen adózási technikákat. A tanúsítvány segít visszaállítani a bizalmat a vásárlók és a vállalatok között, ez is a szignálozás egy fajtájának tekinthető. (https://fairtaxmark.net/, 2020)

Végül bizonyos illegális tevékenységek a totalitárius hatalommal szembeni ellenállásként jelennek meg. A politikai konfliktusokat (tüntetés, sztrájk, szavazás, felkelés) általában nyílt formájukban szokták vizsgálni. James Scott elemzése szerint (Scott, 1996 (a)) azonban vannak olyan kollektív ellenállási formák, amelyek politikai hatalommal nem rendelkező csoportok számára nyújtanak lehetőséget arra, hogy kifejezzék ellenállásukat a hatalommal szemben. Akkor alkalmazzák ezeket az eszközöket, amikor a nyílt ellenállás túlságosan kockázatos. Az általában kisléptékü akciók nem kívánják magukra vonni a figyelmet, sőt, kifejezetten céljuk az anonimitás, azonban a nyílt ellenálláshoz hasonlóan valamilyen intézmény megváltoztatásának irányába hatnak.

Hétköznapi ellenállásról akkor beszélhetünk, ha ezek a tevékenységek kollektív és szándékolt cselekvésként jelennek meg, és az ellenállók anyagi érdekének érvényesítése a cselekvés célja, amit közvetlenül (például: adó vagy tized elcsalása) vagy szimbolikus eszközökkel (például: pletyka, rágalom) kívánnak elérni. Formái sokfélék lehetnek, mindegyiknek az a célja, hogy valamilyen eltulajdonítást segítsen elö. Scott ismertet néhány tipikus példát, amelyek különböző korokban és földrajzi területeken voltak megfigyelhetők. 
A vadorzás 1650-1850 közötti Angliában a leggyakoribb bünözési forma volt. A parasztok, bérlők és kisbirtokosok a lehetőségektől függően akármilyen jószág (fa, vad, tőzeg, nád) megszerzésével rövidítették meg a birtokosokat. Bár a vadorzókat viszonylag nehéz tetten érni, ilyen elterjedt bünözési formává csak a falusi népesség összejátszásával vállhatott.

Az adófizetési kötelezettség a parasztok körében szintén ellenállást válthat ki. Scott a Malajziában kötelezően bevezetett iszlám tized elleni sikeres ellenállás példáját írja le. Az 1960-ban kötelezően bevezetett adót elvileg jótékony célokra kellett volna felhasználni (iskolák finanszírozása, szegényeknek nyújtott segély). Az adó hatálya, a beszedése és később a visszaosztása igazságtalan volt. A parasztok nem lázadtak nyíltan a törvény ellen, azonban mindent elkövettek, hogy az elöírt mennyiség töredékét szolgáltassák be. Például kevesebb földterületet vallottak be, vizes, kaviccsal kevert rizst szolgáltattak be. A szerző becslése szerint a beszolgáltatandó mennyiségnek mindössze $20 \%$-át adták át.

A dezertálás a harmadik kiemelt ellenállási technika. Dezertőr az, aki katonai alakulatát elhagyja, megszökik. Tágabb értelemben az is dezertőr, aki valamely ügyet hagy el. A szerző szerint a kevésbé jelentékeny adók és adminisztrációs kötelezettségek elkerülése szintén dezertálást jelent. (Scott, 1996 (a)) (Scott, 1996 (b))

Az államszocializmussal szembeni ellenállás a hétköznapi ellenállás negyedik példája. Például a jelentős beszolgáltatási kötelezettségek változatos terményeltitkolási gyakorlatot alakítottak ki Magyarországon az 1950-es években.

Az állam reakciója a hétköznapi ellenállására szintén többféle lehet. Az állam választhatja a közvetlen nyílt fellépést az ellenállás ellen, mint tette a 18. századi Angliában a vadorzás ellen hozott „Black Act” bevezetésével. A törvény értelmében az erdőben fekete ruhában lévő ember automatikusan vadorzónak tekintendő. A tapasztalatok szerint az ilyen fellépés kihangsúlyozza a tevékenység ellenállás jellegét, sőt az ellenállás szimbólumává teszi azt.

A közvetlen fellépéssel az állam beismeri a problémát, azt, hogy politikája népszerütlen, hatalma ingatag. Ezért logikus döntésnek tünik, ha a problémáról nem vesz tudomást, a jelenség a hivatalos iratokban, jelentésekben, feljegyzésekben nem is jelenik meg. 
Az államszocializmussal szembeni ellenállás esetén is ez történt Magyarországon. Köztudott volt, hogy a beszolgáltatásokat nem lehet teljesíteni, a csalások időnként a párthivatalnokok tudtával történtek. Ugyanakkor a szerző szerint a parasztság szocializmussal szembeni ellenállása volt a hatvanas évek gazdasági reformjainak oka, és közrejátszott az 1956-os forradalom kirobbanásában is. Ebből a szempontból az ellenállás hatékonynak bizonyult. (Scott, 1996 (b))

\subsection{6. Összefoglaló}

Az illegális magatartás megértésének fontos tényezője az önérdekkövetés mellett a szociálpszichológiai faktorok feltérképezése is. A csoportok fennmaradásának és céljaik elérésének érdekében alakult ki a csoportokkal, családdal való együttmüködés, ill. a kulturális- és normarendszerek. Az ezzel járó magatartásformák a piaci integrációba nem illeszkednek, és olyan erkölcsi rendszert valósítanak meg, amelyek mellett nem a felderítés és büntetés alapján történő optimalizálás a fő elv.

A kormányzat szakpolitikai célkitüzéseihez meghatározott ösztönzési rendszer alapfeltevése általában a racionális magatartáson alapuló optimalizálás. Azonban az ösztönzők a korábban erkölcsi alapon müködő folyamatokat a piaci integráció körébe vonják, és így a normarendszer müködését akadályozzák, számolják fel. A piacgazdaság és a jól müködő normarendszer mégsem egymást kizáró jelenségek, hiszen az idegenekkel és a kormányzattal szemben kialakuló magas bizalom jelentős társadalmi tőke felhalmozódását idézi elő, és ez a piacgazdaság hatékony müködését eredményezi.

A kilátáselmélet felhívja a figyelmet arra, hogy a racionalitás nem müködik a csalás esetén, ennek többféle oka lehet, a kognitív torzítás, a proszociális tényezők, az információs aszimmetria és a döntéshozók személyiségjegyei.

A kilátáselmélet szerint az adócsalás csökkentése érdekében amnesztiát kellene hirdetni az adóelkerülőknek, erősíteni az adózókban a szabálykövető magatartás miatt kialakuló pozitív képet, és lehetőség szerint elkerülni, hogy köztudottá és szokásosan elfogadott magatartássá váljon a csalás. (Ariely, 2015)

Ezektől a tényezőktől függetlenül az illegális tevékenységek megjelenése bizonyos időszakokban törvényszerü. Ilyen a piacgazdaság kialakulása, illetve azok az esetek, amikor az állam elnézi, vagy hallgatólagosan támogatja bizonyos illegális tevékenységek folytatását. Erre példa a gazdasági válságok esete, amikor sokat elvesztik munkájukat, és a megélhetésük érdekében kénytelenek illegális tevékenységekkel fenntartani magukat. 
Végül a gazdasági szereplő és a hatalom kapcsolata is illegális tevékenységeket generálhat, amennyiben a hatalom totalitárius. Ha a politikai párbeszéd nem lehetséges, a nyílt ellenállás túl kockázatos, akkor a hétköznapi ellenállás - az adók, beszolgáltatások, adminisztratív kötelezettségek elkerülése - politikai mondanivalót jelenít meg.

Az illegális tevékenységek tehát sokféle okokból lehetnek jelen, amelyek súlya időben változik. Az adócsalás esetében a különböző motivációk eltérő magatartásformákat eredményeznek - elég csak a szervezett lánc áfacsalások és a kis volumenű számla nélküli értékesítésekre gondolni. Emiatt az adócsalók sokasága rendkívül heterogén lehet, particionálásuk a különböző motivációk és magatartásformák mentén lenne lehetséges.

\subsection{A nem megfigyelt gazdaság alakulása Magyarországon}

Ebben a fejezetben áttekintem a második világháború végétől napjainkig tartó időszak részben vagy teljes mértékben illegális tevékenységeinek alakulását. Az elemzésben az egyértelműen bűnözés körébe tartozó tevékenységek, mint például prostitúció, drogkereskedelem, csempészet, orgazdaság vizsgálatára nem térek ki.

A dolgozatban vizsgált időszakra (2006-2016) jellemző áfacsaló viselkedést természetesen közvetlenül befolyásolják az áfával kapcsolatos jogszabályok, azonban ezek hatása nem kizárólagos, hiszen különben nem lenne akkora különbség az egyes országok adócsaló magatartása között. Az előző fejezetben bemutatott tényezők közül a proszociális viselkedés struktúrája, a társadalmi tőke és a bizalmi szintek szerkezete, továbbá a történeti tényezők hosszú távú hatással bírnak.

A rendszerváltás időszakában úgy tűnt, hogy Magyarországon a második gazdaság létrejöttével a már a szocializmus idején kialakult a magánszektor és a magántulajdon, a piaci mechanizmus spontán fejlődött ki. A központosított gazdaság mellett alulról fejlődve úgy formálódott, hogy a kormányzat képviselői „szemet hunytak” a szabályok megszegése, kikerülése fölött. (Kornai, 1989) A kézenfekvőnek tünő következtetéssel szemben, miszerint ez a szokatlan körülmények között kialakuló piaci normarendszer öröklődött volna át, és okozott volna tömeges és nagymértékű adócsalást később, a helyzet sokkal árnyaltabb.

A fejezetben bemutatom, hogy a szocializmusban létrejött nem megfigyelt vagy a második gazdaságba tartozó tevékenységek mind egy-egy speciális körülményre adott 
rendszerspecifikus válasznak tekinthetők, amelyek kezdetben stabilizáló funkciót töltöttek be. A gazdasági kényszer, a pénzhiány, a gazdaságpolitikai kényszerpálya befolyásolta a gazdasági szereplők magatartását, ugyanis arra ösztönözte őket, hogy a problémákra egyéni megoldásokat találjanak, és ez általában kormányzat hallgatólagos támogatásával, beleegyezésével valósult meg. Jelentős hatással volt az informalitás magas szintje, ami a második és a formális szocialista gazdaságot egyaránt jellemezte. A második gazdaságra jellemző tevékenységek és magatartásformák addig müködtek, ameddig a kiváltó tényező fennállt. Azonban a kormányzattal szembeni bizalmat a kettős kommunikáció és a problémák „kiszervezése” meggyengítette.

Az átmenet a szocialista rendszerből némileg hasonló a kapitalizmus kialakulásának átmeneti időszakához, csakhogy sokkal gyorsabban ment végbe. A rendszerváltás során az átalakulás speciális helyzetet teremtett, amelyben a gazdasági szereplőknek a korábbitól lényegesen eltérő környezetben kellett tevékenykedniük. A megváltozott körülmények között új, csak arra az időszakra jellemző speciális mechanizmusok léptek müködésbe. Az ekkor megjelenő szabályszegő, informális gazdaságba tartozó tevékenységek nagyban elősegítették a rendszerváltással járó válság átvészelését, enyhítették a mélységét.

Az átmenet a kétezres évek elejére fejeződött be. A kapitalista Magyarország nem megfigyelt gazdaságát és az adócsalást részben meghatározta a szocializmusban és az átmenet időszakában megváltozott normarendszer, az állam iránti alacsony bizalmi szint. A stabil piacgazdasági keretrendszerben, ahol a gazdasági növekedés jellemző, a jelentős nem megfigyelt gazdaság (adócsalás, informális kapcsolatok nagy szerepe) akadályt jelent a hatékony gazdasági müködésében. Ennek megfelelően ekkor a kormányzatnak ezek leépítésére kell törekednie.

A fejezet nagymértékben épül a 2018-ban az IARIW, 35th General Conference keretében prezentált tanulmányomra (Ritzlné Kazimir, 2018).

\subsubsection{Nem megfigyelt gazdaság a szocializmusban}

Ebben az alfejezetben a szocialista rendszeren belüli jellegzetes nem megfigyelt, a szocialista gazdaságot kiegészítő vagy vele párhuzamosan müködő tevékenységek közül a második gazdaság tevékenységeit, a hálapénz jellegzetességeit és a beszolgáltatási rendszerben müködő sajátos mechanizmusokat mutatom be. 


\subsubsection{Az atomizáció következményei}

Ebben a fejezetben ismertetem, hogy a nem megfigyelt tevékenységek hogyan járulhatnak hozzá egy rendszer destabilizálásához, és okoznak bizalomvesztést. A folyamat az 2.2.5 alfejezetben ismertetett politikai ellenállásnak a gyakorlati példája.

A beszolgáltatási rendszer az 1940-es években alakult ki. Bevezetése a nyilvánvaló készletfelhalmozáson kívül a világháború utáni években jelentős jövedelemátcsoportosítást is jelentett az újjáépülő és a hidegháború miatt fontossá váló ipar irányába a nyomott és rögzített árak miatt. Továbbá, a növekvő beszolgáltatási kötelezettségeken keresztül nyomást gyakorolva, szövetkezetekbe kényszerítette a parasztokat.

A parasztoknak a mezőgazdasági termékek széles skáláját kellett megtermelni adott összetételben, hogy a terményadó kötelezettségének eleget tudjanak tenni, miközben a paraszti gazdaságok mérete öt hold körüli volt. A követelmények irreálisak voltak, a kis birtokokon lehetetlen volt évről évre a növekvő beszolgáltatási követelményeknek megfelelni. A szinte lehetetlen kihívás által kikényszerített önellátásnak köszönhetőnek növekedett a parasztok gazdasági függetlensége. (Rév, 1996)

A szocializmus antiindividualista, mert a termelés és a tulajdon közti ellentmondást szeretné feloldani. Ennek érdekében mégis az egyéni tevékenységek tökéletes megtervezésére kell törekednie. A terv megvalósítása több okból is problémás volt, azonban a felosztás és aggregálás eltérő módszertana miatt egyszerüen lehetetlen volt teljesíteni.

A teljesítési problémák miatt minden résztvevőnek érdeke volt az adatok torzítása és hamisítása, mire az adatok a központba kerültek, sokszoros alakításon estek át. ${ }^{4} \mathrm{~A}$ következő terv az előző terv sarokszámait törvényszerűen meghaladta, és mindenki előre tudta, hogy teljesíthetetlen, hiszen az előző, nem teljesített tervre épült a kiszámítása.

Az adatok kozmetikázásán túl több eszköz is rendelkezésre állt, hogy a terményadó alól kibújjanak a parasztok. A nyilvántartott földterületek az adásvételek során drasztikusan csökkentek, müködött a feketepiac, sokan meghamisították a születési anyakönyvi kivonatukat, mert a 65 évnél idősebbeknek alacsonyabb volt a terményadó

\footnotetext{
4 A folyamatot nagyon jól érzékelteti Hofi Géza A disznó mennyit fog fialni címủ előadása (https://www.youtube.com/watch?v=bVAKkeLg3mE).
} 
kötelezettségük. A termelöszövetkezeti tagoknak nem kellett a beszolgáltatásban részt venni, ezért feltételezhető, hogy ál termelöszövetkezeteket alakítottak emiatt.

A beszolgáltatások elkerüléséhez általában össze kellett játszani a községi adminisztrátorokkal és a hivatalnokokkal. Nekik minden kreativitásukra szükségük volt, amikor az adatok manipulálása már nem segített, hogy a terv alulteljesítéséhez hihető történetet találjanak ki. A terv nem teljesítése a Tervhivatalra is nyomást gyakorolt, a terveket rendszeresen átírták, főként év vége felé, hogy a valós termeléssel jobban egyezzenek.

Minden évben nagyobb hiány alakult ki valamelyik termékből. A következö évben ennek a terméknek a termelésére koncentráltak, ami újabb hiányt generált. A rendszernek nem lehetett megfelelni, mert aki a kampányszerü termelési versenyben nagyon jól teljesített, az lett a következő évi hiány felelőse. Aki pedig ennek a fenntarthatatlanságát átlátva megpróbálta mérsékelni a következményeket, szabotázst követett el. Az összejátszás, a nemteljesítésekről való hallgatás és a számok kozmetikázásának stratégiája azonban az egyre növekvő beszolgáltatási terhek mellett nem volt sokáig tartható. Magyarországon az 1952. év volt az elnyomás mélypontja, amikor a rossz termés tovább rontotta a beszolgáltatások eredményességét. Ekkorra a rendszer fenntarthatatlanná vált.

Egy totalitárius rendszerben a politikai párbeszéd lehetetlensége a valóságban minden tettet, a beszolgáltatásokkal kapcsolatos nem teljesítéseket is politikai tetté avat, és ezzel a terror és elnyomás növekedését okozza. 1953-ban megbukott a sztálinista politikai rendszer Magyarországon, a bukást legalábbis részben a parasztság ellenállása okozta. Amint a liberalizálás elkezdődött, a struktúraváltással az általános zürzavarban a beszolgáltatásokat a parasztok leállították. A beszolgáltatás 1954-ben volt a legalacsonyabb, aminek következtében megkísérelték visszaállítani a korábbi rendszert, de a feszültség miatt a kényszerbegyüjtéseket leállították. Az 1956-os forradalom alatt az első hivatalos intézkedés a beszolgáltatási rendszer eltörlése lett.

A parasztok ellenállása és az arra reagáló apparátus aláásta községi közösségekben a bizalmat, a gyanakvás és a feszültség a büncselekmények drasztikus növekedését idézte elö, és végső soron a helyi közösségek felbomlását okozta. Mindemellett a kormányzattal szembeni bizalomvesztés szintén jelentős volt. (Rév, 1996) 


\subsubsection{A második gazdaság kialakulása}

A második gazdaság kifejezést Grossman vezette be 1977-es cikkében. Definíciója szerint második gazdaságba tartozónak tekinthető az a termelő vagy cserére irányuló tevékenység, amely a következő két jellemző közül legalább az egyiket teljesíti: (a) a szocialista gazdaság célkitüzésével szemben közvetlenül az egyéni nyereség szerzésére irányul, (b) a fennálló törvényeket megsérti. (Grossman, 1977, old.: 25) Grossman a szovjet viszonyoknak megfelelően a mezőgazdasági kistermelést, az egyes szakmák önálló művelését (pl: fogorvos), a korrupciót, a sajátlakás építést és az államtól való lopást és ezeknek a javaknak a kereskedelmét érti. (Grossman, 1977)

A második gazdaság az adott ország viszonyaira, gazdasági helyzetére reflektálva alakult ki, ezért a hasonlóságok ellenére az érintett országok között közvetlenül nem összehasonlíthatók. A második gazdaság magyarországi sajátosságait részletesen GáborGalasi: „A „második” gazdaság” címü könyve ismerteti. A szerzők a második gazdasághoz tartozónak a magángazdaságot tekintik, az általuk használt fogalom a szovjet mintától eltérő jelentéssel bír. (Sik, 1996) A vizsgálatba bevont tevékenységek között legális és illegális elemek egyaránt vannak, elemzésükböl kihagyják azonban a büntetőjoghoz tartozó tevékenységeket. (Gábor \& Galasi, 1981, old.: 21.)

A második gazdaság kialakulása Magyarországon az 1960-as évek első felére tehető, amikor a jelentős munkapiaci túlkínálat, az inaktívak viszonylag magas létszáma és az állandó áruhiány miatt egyes tradicionális tevékenységek - főként mezőgazdasági kistermelés - megerősödtek az állami szektoron kívül. Stabilizálták a gazdaságot, választ jelentettek a jelentős társadalmi és gazdasági problémákra. A kormányzat hivatalosan nem támogathatta a második gazdaságot a szocialista feltételrendszer mellett, ugyanakkor szükség volt rá, ezért a „türt” kategóriába került.

Az 1970-es évekre a gazdasági racionalitás lett a második gazdaságban való részvétel fő motivációja. A mezőgazdasági kistermelés mellett hangsúlyossá váltak a magánvállalkozások a magánkisipar és a kiskereskedelem területén, amelyek átvették a hiányzó szocialista kisvállalatok szerepét. Emellett jellemző volt még az ingatlan bérbeadás (nyaraló vagy lakás), magánlakás építés, ill. a korrupció (borravaló, csúszópénz, hálapénz). A második gazdaságban való részvétel jó része nem teljes munkaidőben, hanem kiegészítő tevékenységként, állami vállalatnál való foglalkoztatás mellett valósult meg. 
A mezőgazdasági kistermelés olyan háztáji gazdálkodás, amely nem önfogyasztásra való termelés, hanem piaci kibocsátást jelent. Nagysága elérte az összes mezőgazdasági kibocsátás több mint egyharmadát. A magánkisipar a szolgáltatások felét, míg a magán kiskereskedelem az összes kiskereskedelmi forgalom egyhatodát jelentette. A saját kivitelezésű lakásépítés kalákában, vagyis munkacsere formájában történő építkezéseket jelent, a lakások fele így épült.

A központi irányítás miatt a szocialista gazdaságban nem müködik az ármechanizmus, a bérek nem rugalmasak, ezért a munkavállalók teljesítményük szabályozásával tudnak reagálni a változó körülményekre. A második gazdaságban ezzel szemben működik az ármechanizmus, nagyobb a munkaintenzitás, és magasabb a jövedelem. Az életszínvonal szubjektív értékelése a második gazdaságban foglalkoztatottak valósnál magasabb jövedelmét érzékeli. Ez az állami foglalkoztatottak teljesítménycsökkentésének az irányába hat. Ugyanakkor a második gazdaság bekapcsolásával a termelést az elvárt szintre lehetett hozni, a jövedelmeket újra lehetett osztani, ezért a második gazdaság kiegyensúlyozta, kiegészítette a szocialista gazdaság müködését, és elősegítette a rendszer politikai stabilitását.

A második gazdaság árutermelő része - a mezőgazdaság és az ipari tevékenységek - a szocialista gazdaság szerves részét képezték. A szövetkezetektől, nagy állami vállalatoktól kiszervezett, bedolgozó jellegü tevékenységek önállóan teljesen életképtelenek voltak, a vállalkozás intézményi feltételeit nem teljesítették (önálló döntéshozatal, többi szervezeti egységtől elkülönült müködés és jövedelmek). A rendszerváltáskor a szövetkezetek, nagy állami vállalatok megszünésével, átalakulásával elvesztették a keresletet. A háztáji termelés esetén a saját fogyasztásra vagy piacra termelés valamelyest átvette a szövetkezeti megrendelések szerepét. Ezért a mezőgazdasági kistermelés lassabban esett vissza.

A rendszerváltás a vidéki népesség jövedelmét drasztikusan csökkentette a szocialista gazdaság összeomlásán és a második gazdaság termelésének csökkenésén keresztül. A főbb jövedelemforrások megszűnésével tömegek szegényedtek el.

A saját kivitelezésű lakásépítések jelentősége szintén csökkent a rendszerváltás után. A tevékenység legfontosabb motivációja az elégtelen lakáspiac volt, a nagy túlkereslet, a pénzhiány és a lakáselosztás döntési anomáliái, amelyek a rendszerváltás után fokozatosan megszüntek. 
A szolgáltatások területén müködő kisvállalkozások legálisan, önálló szervezetként, tényleges piacon müködtek, keresletet termékük iránt a háztartások jelentették. A rendszerváltás után is tovább müködhettek, azonban nem tették ki az ország gazdasági teljesítményének számottevő hányadát.

A második gazdaság tevékenységeinek jó része nem szerveződött önállónak tekinthető vállalkozásba, és a termelés jelentős része megszünt vagy fokozatosan elvesztette jelentőségét a rendszerváltás után. A rendszerváltás után ugrásszerüen megnőtt vállalkozások száma, ezek közül viszonylag kevés müködött az előző rendszerben is. Ezért nem feltételezhetjük, hogy a rendszerváltás utáni általánosan elterjedt adócsalás közvetlenül a második gazdaságnak lenne köszönhető.

Gábor és Galasi nem tekintették az informalitást a második gazdaság részének, bár kiemelték annak jelentős szerepét a szocialista vállalaton belül. (Gábor \& Galasi, 1981) Az azonban jellemző volt az általuk vizsgált tevékenységek egy részére, ugyanis az informalitás jórészt reciprocitáson alapuló kapcsolatokat, ill. alacsony piaci szervezettségi szinten megvalósuló piaci integrációs formákat tartalmaz. Negatív morális tartalma nagymértékben a kapitalista gazdasági modell idealizálásának köszönhető. Azonban megítélése nem egyértelmű, mert bizonyos esetekben hozzájárul a hatékonyság növekedéséhez és a kreatív megoldások kidolgozásához. ${ }^{5}$

Az informalitás szervezeteken belüli jelenléte miatt jelentősen leegyszerüsítő az a feltevés, miszerint a szocializmusban jelen lévő második gazdaságra az informalitás, a szocialista gazdaságra pedig a formalitás lett volna jellemző. A szocialista gazdaságot is átszőtte az informalitás. A vállalatokon belüli hálózatok és vállalatvezetők kapcsolatai természetes velejárói bármilyen gazdasági rendszernek. Ezeknek a hálózatoknak egy része a rendszerváltás után is tovább élt, és résztvevői számára nem formális csatornákon keresztül előnyöket biztosított. (Böröcz, 2000)

A második gazdaság hatása a rendszerváltás utáni nem megfigyelt gazdaságra a második gazdaság sokszínűsége miatt nem egyértelmü. A fentebb említett informalitás, és az olyan tevékenységek, mint a sajátkivitelezésű lakásépítés a reciprocitáson keresztül a nem

\footnotetext{
${ }^{5}$ Az informalitás magas szintjének a kialakulására magyarázatot adhat gazdaság és társadalomfejlődés Magyarországon. Mivel tőke hiányában a klasszikus kapitalizmus Magyarországon nem alakult ki, a nagy szervezetek sem jelentek meg olyan mértékben, mint Nyugat-Európában. A formalitás, mint norma a megfelelő háttér miatt nem tudott beépülni a társadalmi folyamatokba. Ez az informalitás gazdasági rendszertől függetlenül jelen volt az elmúlt időszakokban. (Böröcz, 2000)
} 
megfigyelt tevékenységekre pozitív hatást gyakorolt. A második gazdaságban végzett tevékenységek azonban másokkal szembeni bizalomvesztést is okoztak. Az ügyeskedés, a teljesítményszabályozás (állami munkahelyen alacsonyabb a termelékenység), az ennek következtében fellépő magasabb jólét a magánszektorban tevékenykedők iránt gyanakvást eredményezett ${ }^{6}$.

A társadalmi rétegződés vizsgálatát státuszindexek segítségével lehet kivitelezni. Kolosi Tamás ordinális státuszindexeket alkotott, az általa használt tíz index a település, övezet, lakás, jövedelem, fogyasztás, vagyon, kultúra, foglalkozás, munkakörülmények, érdekérvényesítés és a második gazdaság területeket fedték le. A második gazdaságra vonatkozó index rendhagyó volt a többihez képest, amelyek egymással mind pozitív korrelációban álltak. A második gazdaság a tíz indexből kilenceel gyenge negatív korrelációban állt, csak a vagyon indexszel volt rendkívül gyenge, de pozitív kapcsolata. Mindebből az következik, hogy a második gazdaságban való részvétel az alacsony társadalmi státusz kompenzálására szolgált. A státuszindexek faktoranalízise igazolta, hogy a második gazdaságban való részvétel a társadalmi rétegződés független, önálló tényezője. Ugyanakkor a társadalmi rétegződés modelljeiből nyilvánvaló, hogy a második gazdaságban való tevékenység bárki számára nyitott. A részvétel az életkörülményeket javítja, de nem tesz lehetővé rétegváltást. (Kolosi, 1984)

A második gazdaságban végzett tevékenység rétegspecifikus. A falusi népesség $90 \%$-a részt vesz a mezőgazdasági kistermelésben, a falusi rétegek között ebben nincs szignifikáns különbség. Ezzel szemben a városokban a nem mezőgazdasági második gazdaságbeli tevékenységek rétegző szerepe jelentősebb. Megnöveli a jómódúvá válás esélyét, ám nem biztosíték a szegénység elkerülésére. A második gazdaságban való részvétel a városokban az értelmiségiek belső rétegződésére hatást gyakorol, míg a munkások rétegződését nem befolyásolja. (Kolosi, 1987)

\subsubsection{A hálapénz}

A hálapénz (paraszolvencia) ${ }^{7}$ szintén nem megfigyelt tevékenység, kialakulása vagy még inkább kialakítása a háború utáni szocialista diktatúrával függ össze. Ellentmondásokkal

\footnotetext{
${ }^{6}$ A maszek szó, amely különösen a rendszerváltás előtt volt elterjedt, a magánszektor rövidítéséből ered. Kettős jelentésű volt a szó, egyik jelentése: kiváló, jó minőségü, másik jelentése pejoratív a magánszektorban dolgozókra. Jelenleg az adók és járulékok kikerülésével megvalósuló tranzakciókat jelenti.

7 A hálapénz nem magyar specialitás, Kelet-Közép-Európában több országban, például Litvániában, Romániában is jelentős problémákat okoz. (Európai Bizottság, 2014, old.: 81)
} 
teli történetét Ádám György „Az orvosi hálapénz Magyarországon” (1986) című könyve rekonstruálja. (Ádám, 1986)

A II. világháború előtt a társadalombiztosítás nem volt tömegesen elterjedt Magyarországon, az egészségügy magánfinanszírozással müködött, az orvosok szolgáltatásukért honoráriumot kértek, a szegények ingyenes ellátása ugyanakkor kötelező volt. A honorárium természetbeni juttatás is lehetett, sőt, ahol kevés volt a pénz, ott ebben a formában volt természetes.

A második világháború előtt nem volt hálapénz semmilyen területén az egészségügynek, az a második világháború után, a szocialista rendszer kiépítése során alakult ki, megjelenésének alapvetően három oka volt.

1. Az infrastruktúra, a kórházak és rendelőintézetek a háború során jelentős károkat szenvedtek, a szocialista rendszer viszont a vasút újraépítésére helyezte a hangsúlyt.

2. A kötelező társadalombiztosítás bevezetésével majdnem mindenki számára ingyenessé vált az egészségügyi ellátás, ami hirtelen túlkereslethez vezetett.

3. A Rákosi-korszak bérpolitikája, miszerint senki sem kereshet többet egy szakmunkásnál, az orvosok számára jelentős bérfeszültséget jelentett.

A fenti tényezők miatt várólisták alakultak ki, a „hálapénz” a betegek természetes reakciója volt. Az orvosokat zavarta a hálapénz megjelenése, azonban az orvosi kamara háború utáni megszüntetése miatt hiányzott a megfelelő fórum az érdekérvényesítésre és a közös fellépésre. A kormányzat 1950-ben vált a hálapénz rendszer aktív alakítójává, az orvosok bérének rendezésével (40/1950 Mt. rendelet). Ez volt az első alkalom, amikor az orvosok bérét úgy határozták meg, hogy belekalkulálták a bérekbe a hálapénzhez jutás lehetőségét. Azoknak az orvosoknak a fizetését, akik hálapénzt kaphattak (például a szülészek), jelentősen alacsonyabb szinten határozták meg, mint azokét, akiknek erre kevésbé volt lehetőségük (például a gyermekorvosok vagy patológusok).

Az ötvenes évek végén a hálapénzt etikai problémaként kezelték, és nem jogi kérdésként, holott az akkor hatályos Btk. szerint (1878. évi V. tc, a Csemegi kódex) az orvos közhivatalnok, a lefizetése büntetendő. Hasonlóképpen az 1942. évi X. tc a közéleti visszaélésekről a 4. §-ban egyértelműen megtiltja az orvosnak az ajándék elfogadását a betegektől. A hálapénz etikai problémaként való kezeléséből úgy tünik, hogy megszüntetésére nem volt meg a kormányzati szándék. 
Az Orvosi rendtartásról szóló 1959. évi VIII. tvr. nem oldotta meg a hálapénz problémáját, hanem inkább intézményesítette. Preambulumában az szerepelt, hogy az ingyenes és magas színvonalú orvosi ellátásra mindenkinek joga van, azonban az átalakulóban lévő gazdasági és társadalmi viszonyok ezt még nem teszik lehetővé. Az Orvosi rendtartáshoz kapcsolódó végrehajtási rendelet szabályozza, hogy az orvosetikai bizottságoknak akkor kell feljelentést tenniük, ha az ajándékozás „olyan időben” vagy az orvos kifejezett kérésére történik. Ez az egyetlen olyan pont, amikor jogszabályban történik utalás az ajándék adásának idejére, és ez indította útjára azt a hiedelmet, hogy az utólagosan adott ajándék vagy hálapénz jogilag megengedett.

A hálapénz történetének kezdetétől a hatvanas évek végéig a kormányzat megengedő volt a hálapénz adásával szemben, de folyamatosan hangsúlyozta, hogy ez átmeneti jelenség, ami később meg fog szünni. A hatvanas évek szociológiai kutatásai megmutatták a hálapénz elterjedtségét, és a motivációit is megvilágították. A szokás és a rosszabb ellátástól való félelem volt a legfontosabb indok a hálapénzt nyújtók között, a hála csak a válaszadók töredékénél indokolta a paraszolvenciát.

A hetvenes években ismételten napirendre került a hálapénz problémája, a kormányzat által hirdetett orvosetikai akcióprogram azonban teljesen eredménytelen volt. Ezután a hálapénz elleni kormányzati fellépés 2020. őszéig nem vett új lendületet, változatos indoklások „támasztották alá”, hogy megszüntetése miért nem lehetséges vagy aktuális.

Ádám György szerint mindössze két intézkedés kellene a hálapénz megszűntetéséhez:

1. az orvosok olyan bérrendezése, amely nem kalkulál a hálapénzzel

2. a kormányzat határozott kijelentése, hogy a hálapénz adás és elfogadás egyaránt tilos.

A 2020. évi C. törvény Az egészségügyi szolgálati viszonyról az orvosok jelentős, három lépcsőben megvalósuló béremelését tartalmazza. Továbbá a Btk. (2012. évi C. törvény $290 \S$ (6)) kiegészült a hálapénz adás kriminalizálásával, a hálapénz fizetése egy év szabadságvesztéssel büntetendő. Ezzel a hálapénz több mint hetven éves története remélhetőleg véget ér.

A hálapénz története klasszikus példa arra, hogy a gazdasági és politikai helyzet hogyan „kényszerítette” arra a döntéshozókat, hogy illegális tevékenységbe sodorják a társadalom jelentős részét. A hálapénz ugyanakkor aláásta a kormányzatba vetett 
bizalmat a kettős kommunikáció és a megszüntetésére irányuló szándék nyilvánvaló hiánya miatt.

\subsubsection{A rendszerváltást követő időszak}

A szocializmus és a piacgazdaság közötti átmenet nem közvetlenül és egyszerre ment végbe. A szocialista paradigmarendszer érvényessége nem egyik napról a másikra szünt meg, ahogy a piacgazdaság (kapitalizmus) sem egy adott időponttól lépett müködésbe. Az átalakulás nem tekinthető egyfajta vegyes állapotnak sem, amikor az egyik és másik paradigmarendszerből is müködnek bizonyos mechanizmusok egymást kiegészítve. Sokkal inkább gondolható önállónak, amikor sajátos szabály és intézményrendszer müködik a társadalomban. Az átalakulás befejeződése természetesen szintén nem köthető egy időponthoz. A magyar átalakulási periódust Kornai János 1999-ben még nem tekintette befejezettnek. (Kornai, 1999) Ezért érdemes a rendszerváltás időszakát külön vizsgálni. A dolgozatban a rendszerváltást követő időszaknak a kétezres évek első évtizedétől kezdődő korszakot tekintem.

A fejezetben először rendszerváltástól 2018-ig terjedő időszak gazdasági helyzetét, és a nem megfigyelt gazdaság alakulását tekintem át általánosságban. Ezután a piacok kialakulásának és átalakulásának példáján a rendszerváltás időszakát, mint önálló paradigmával rendelkező gazdasági jelenséget szeretném bemutatni.

Végül a fejezet végén összefoglalom, hogy hogyan vált az adócsalás a kapitalista rendszer kialakulásával, megszilárdulásával és az európai integrációval a gazdaság müködését akadályozó tényezővé. Az adócsalás csökkentését célzó kormányzati intézkedések ismertetésével zárom a gazdaságtörténeti fejezetet.

\subsubsection{A rendszerváltás utáni évtizedek rövid gazdaságtörténeti áttekintése}

A rendszerváltás során a korábbi gazdasági rendszer szinte teljes összeomlása és az új intézményrendszer szerinti fokozatos újjáépülése következett be. Mindez jelentős mértékủ válsággal, és az átállás miatt kiszámíthatatlan gazdasági környezettel járt, ahogy azt a következö, 9. ábra is bemutatja. 
9. ábra: A GDP, a háztartások tényleges fogyasztásának volumenindexe, és a reálkeresetek indexe, $1988=100 \%$

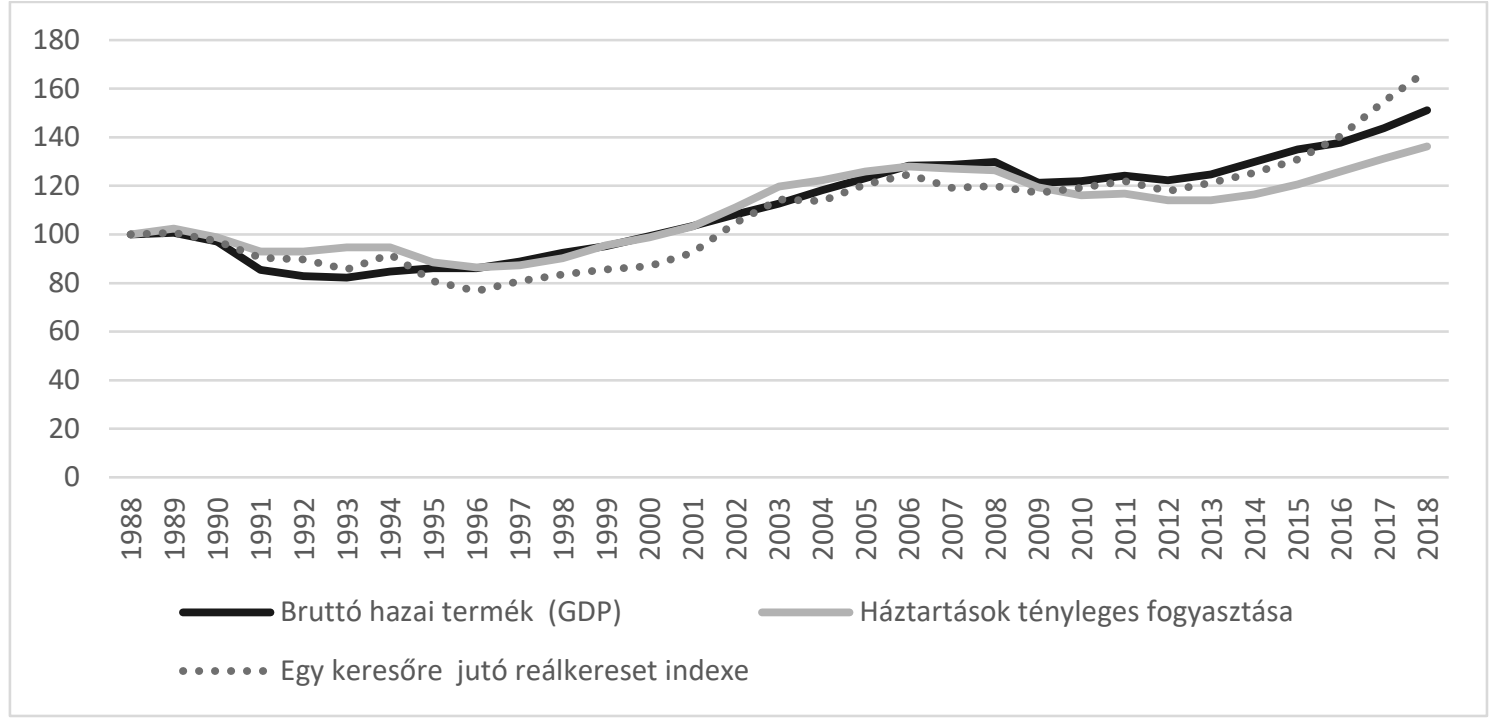

Forrás: KSH Stadat táblák, saját szerkesztés

A rendszerváltás hatását bemutató ábrán 1988-at választottam bázisévnek. ${ }^{8}$ A GDP 1991re az 1988-as érték 85\%-ára esett vissza, a mélypontja 1993-ban volt, ekkorra a bázisév 82\%-ára csökkent. A bruttó hazai termék lassú növekedése 1994-től kezdődött. A reálkereset és a fogyasztás tekintetében a válság lassabban bontakozott ki, mindkét mutató 1996-ban érte el a legalacsonyabb értékét, az 1988-as érték 77, ill. 86,4\%-át. Mindhárom mutató az ezredforduló után érte el az 1988-as szintet, a GDP és a fogyasztás 2001-ben, a reálkereset 2002-ben haladta meg a rendszerváltás előtti értékét.

A kétezres évek elején a magyar gazdaság európai integrációja volt a legfontosabb feladat. Ezzel együtt az infrastruktúra fejlesztés és a mély integrálódás a globális gazdaságba jellemezte az évtizedet. Az export és import GDP-hez viszonyított arányán keresztül, a 10. ábrán mutatom meg, hogyan nőtt a hazai gazdaság nyitottsága.

\footnotetext{
${ }^{8}$ A rendszerváltást hivatalosan az 1989-es évhez kötik, mert a legjelentősebb események (többek között: Nagy Imre és mártírtársainak újratemetése, az ország nyugati határainak megnyitása, az MSZMP megszüntetése, a köztársaság kikiáltása október 23-án).
} 
10. ábra: Az export és az import GDP-hez viszonyított aránya, \%

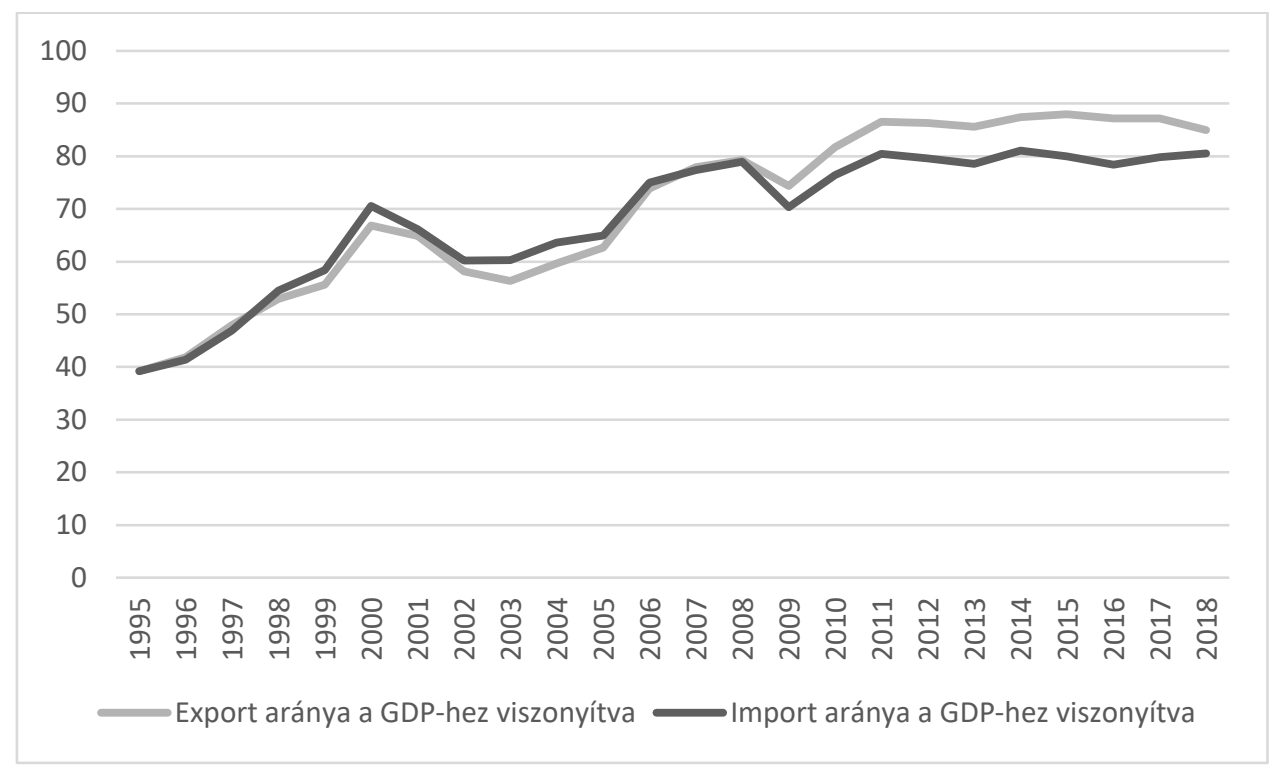

Forrás: ((d), 2020), 3.1.7 Stadat tábla alapján saját szerkesztés

Az integráció a globális értékláncba a multinacionális vállalatok hazai megjelenésével járt együtt. Aszáz legnagyobb hozzáadott értéküvállalat részesedése a hozzáadott értékből 2008-ra elérte a 35\%-ot. (hvg.hu, 2009) Ezekkel a folyamatokkal párhuzamosan az adócsalás és a nem megfigyelt gazdaság magas aránya hatékonyságot csökkentő, zavaró tényezővé vált.

A 2008-ban kirobbant világgazdasági válságot Magyarországon politikai, kormányzati válság előzte meg. A kormányzatba vetett bizalom jelentősen csökkent, és a közéleti botrányok tovább gyengítették a bizalmat. Ugyanakkor a lakosság devizában való nagymértékü eladósodottsága veszélyes méreteket öltött.

A válság erőteljes visszaeséssel járt, és a gazdaság minden szektorára, ágazatára kiterjedt. A munkanélküliségi ráta a 2010-2013 időszakban meghaladta a 10\%-ot. A forint gyengülése miatt kitört devizahitel válság a gazdasági válsággal együtt komoly nehézséget jelentett a lakosságnak, a fogyasztás számottevő mértékben visszaesett. A háztartások fogyasztása 2008-ban már csökkent. A belföldi felhasználás 2012-es visszaeséséhez a fogyasztás és a beruházás alacsony szintje egyaránt hozzájárult. A GDP csökkenést a külkereskedelmi mérleg aktívuma mérsékelte.

A beruházások és a fogyasztás alakulását a következő, 11. ábra mutatja be. 
11. ábra: A háztartások tényleges fogyasztási kiadása és a bruttó állóeszközfelhalmozás 2005. évi áron

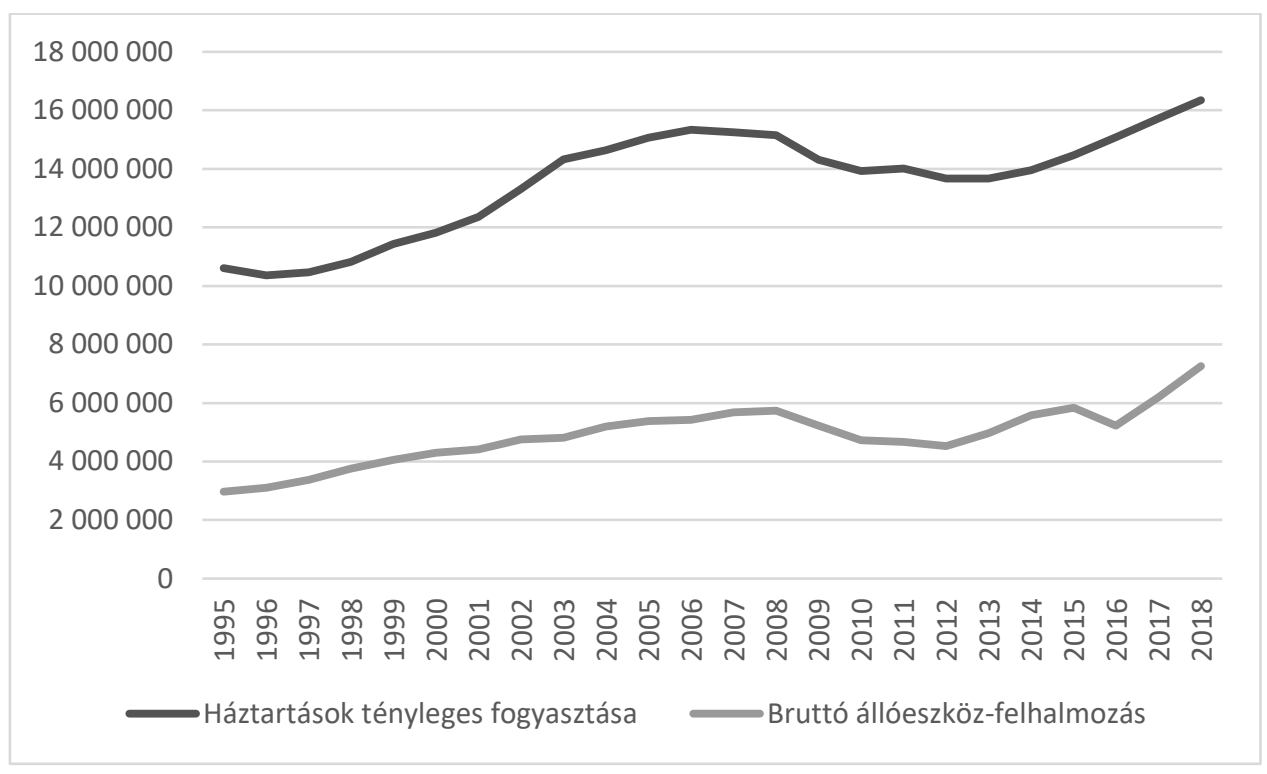

Forrás: ((d), 2020) 3.1.11. Stadat tábla

A fogyasztásban jelentkező hosszasan elhúzódó válság ellenére a bruttó hazai termék növekedése 2013-ban elkezdödött, amelyben nagy szerepe volt a következő tényezőknek:

- Infrastrukturális beruházások megvalósítása EU finanszírozás segítségével (út, vasút, közmüépítések). Kiemelkedő mértékben fellendült az építőipar.

- Mélyebb integráció a globális gazdaságba - különös tekintettel az autóipar és beszállítói láncának kiépülésére. Ezzel együtt az extrém mértékü gazdasági nyitottság tovább növekedett.

- A fenti két tényező együttes hatására a beruházások erőteljesen növekedtek.

- A szolgáltatások, különösen az információtechnológiai szolgáltatások, ill. az adminisztratív szolgáltatások (SSC (shared services center) vállalatok letelepedése miatt) teljesítménye emelkedett.

- Családtámogatás átalakítása, kiterjesztése, egykulcsos SZJA bevezetése egyaránt a végső kereslet növekedésének az irányába hatott. Az intézkedések egyik eredménye a fogyasztás növekedése.

- Ugyanakkor fokozódott az elvándorlás, a munkanélküliség hazai csökkenésével együtt növekedett a reálbér és egyes területeken a munkaerőhiány alakult ki. 


\subsubsection{A nem megfigyelt gazdaság alakulása a rendszerváltást követö évtizedben}

A rendszerváltást követő évtizedben a válság és a tőkehiány határozta meg a nem megfigyelt gazdaság fejlődését. A második gazdaságba sorolt tevékenységek jó része megszünt, a jövedelem, termelés, fogyasztás csökkent. Az állami vállalatok egy része megszünt, a termelés drasztikusan visszaesett.

A gazdasági átmenet során az állami tulajdon magánkézbe adása, a privatizáció is lezajlott. Az előző rendszerben kialakult informális hálózatokat (menedzseri szocializmus) hasznosítva a privatizáció államilag levezényelt tulajdoncsereként írható le, jórészt informális társadalmi mechanizmusok révén. (Böröcz, 2000) (Kolosi \& Szelényi, 2012)

A vállalkozások száma jelentős mértékben megnőtt, azonban sok esetben a cégalapítás az adóelcsalás eszközévé vált, többek között a színlelt alvállalkozói kapcsolatokon keresztül. A privatizált nagyvállalatok mellett a hazai vállalkozások között a kisvállalkozások maradtak továbbra is a jellemzők, a gazdasági struktúra széttöredezetté vált. Ez a jelenség továbbra is fenntartotta az informalitás fontosságát. (Böröcz, 2000)

A rendszerváltás körüli időszakban kialakuló illegális gazdasági tevékenységek jól szemléltetik az intézményrendszer összeomlásának hatásait. Három tényezőre vezethetők vissza. Elsőként gazdasági szereplők „ötletei”, amelyek a zürzavaros jogi és gazdasági helyzetben gyors meggazdagodást jelentettek, lásd például az olajszőkítési ügyeket. Másodikként a jelentős infláció és a pénzügyi helyzet (szigorú szabályok és jelentős tőkehiány) uzsora-ügyletekhez vezetett, amelyeket általában valamilyen valutában „folyósítottak”. Végül a korábbi bürokratikus rendszer leépülésével a biztonságot nyújtó örző-védő vállalkozások szintén az illegalitás határmezsgyéjén (vagy azon túl) működtek. (Bezsenyi, 2020)

Az 1992-ben a rejtett gazdaságra vonatkozó felmérés jól illusztrálja, hogy a rendszerváltás okozta struktúraváltás hogyan változtatta meg a nem megfigyelt tevékenységek szerkezetét. A legnagyobb arányú növekedés a borravaló, szürke és feketepiacok, fusi, adócsalás, fogyasztók megkárosítása és a hálapénz területén volt megfigyelhető. (Ékes, 1993) 
A $\mathrm{KGST}^{9}$ piacok példája megmutatja, hogy az átmenet időszakában megjelenő, nem megfigyelt gazdaság kereteibe tartozó tevékenységek hogyan képesek igazodni a körülményekhez és dinamizálni a gazdaságot. A KGST piac a köznyelvben elterjedt ironikus elnevezése az 1970-es években a gazdasági enyhüléssel együtt megjelenő, kezdetben ad-hoc, informális piacoknak. A KGST tagállamokból jött árusok kihasználták a specializáció és az árszabályozás miatti komparatív előnyöket, a kereskedelemből az árusok és a vevők is profitáltak. Ezeken a piacokon lehetett azokhoz a javakhoz hozzájutni, amikből az adott országban hiány volt, vagy rosszabb volt a minőség. A termékek tekintetében a KGST piacok föként az olcsó iparcikkekre, müszaki cikkekre, élelmiszerekre specializálódtak. (Sik, 1997)

A KGST piacok a nyolcvanas évekre regionálisan szerveződtek. A lengyelek szinte az egész ország területén értékesítették a KGST országokban vásárolt árukat. A román, jugoszláv és később az ukrán határ mellett az úgynevezett kishatárforgalom lehetőségeit kihasználva indult el a kereskedelem.

A KGST piacok a rendszerváltás körül és után virágoztak, mivel akkorra az addig is elégtelenül müködő kereskedelem a KGST-n belül összeomlott. Ezzel együtt járt a jövedelmek jelentős csökkenése, tömeges munkanélküliség, amelyek a keresletet a viszonylag olcsóbb piaci termékek irányába terelték. (Sik, 1997) A rendszerváltás után megjelentek ugyan a drága import termékek a kiskereskedelmi forgalomban, de az általános válság miatt az ezek iránti kereslet alacsony volt. Az informális kereskedelemben az alacsony költségek, az adócsalás és garancia hiánya miatt voltak alacsonyabbak az árak..

A rendszerváltás után a KGST országok között a rögzített valutaárfolyamok rendszere, ezzel együtt az árak szabályozása is megszünt, a legtöbb országban számottevő infláció alakult ki. Továbbá a belföldi termelés átalakult, a vállalatokat privatizálták vagy egyszerüen megszüntek, a termelés visszaesett. Már nem volt annyira egyszerü a komparatív előnyök kihasználása, mint korábban. A piacok fokozatosan elvesztették KGST jellegüket, profilt váltottak.

\footnotetext{
9 A KGST (Kölcsönös Gazdasági Segítségnyújtás Tanácsa) 1949-ben alakult, fö célja a gazdasági együttműködés elősegítése, az elmaradottabb tagállamok felzárkóztatása, ill. a specializáció és a munkamegosztás kialakítása. 1991-ben oszlatták fel a tagjai. Alapító tagjai: Szovjetunió, Bulgária, Csehszlovákia, Lengyelország, Magyarország és Románia. Később csatlakozott Albánia, Mongólia, Német Demokratikus Köztársaság, Kuba, Vietnámi Demokratikus Köztársaság.
} 
A határok mentén kialakult, kishatár-forgalomra épülő kereskedelem a mai napig müködik (lásd például a nyíregyházi piacot). Némelyik piac inkább őstermelői piacként működött tovább, vagy használtcikk piaccá vált. A távolkeleti kereskedők megjelenése a piacokon tipikusnak volt mondható (Czakó, 1997). Termékskálájuk főként ruhanemükből állt. Másik tipikus árucikk az élelmiszer, amiket nyugati országokból importáltak.

A helyi kormányzat hozzáállása is figyelemre méltó a KGST piacokhoz. Az eleinte adhoc módon szerveződő piacokat a helyi kormányzat megpróbálta felszámolni, később azonban az önkormányzatok területet jelöltek ki a számukra. Valószínüleg nyilvánvalóvá vált, hogy ez a fajta kereskedelem szükséges, és nem megszüntethető. A folyamatok jobban kontrolálhatók és az egész piac biztonságosabb, ha kijelölt helyen zajlik a kereskedés.

Az MDF piacokat is érdemes megemlíteni, mint informális piachelyeket. Eredetileg kialakításuk azzal a szándékkal történt, hogy a rendszerváltás után rossz helyzetbe került mezőgazdasági termelők és az alacsony jövedelmű vásárlók a kereskedők közvetítése nélkül találkozzanak. (MTI, 1989) A piacok rövid ideig müködtek az eredeti formájukban, később az élelmiszereken kívül egyéb árucikkek és a kereskedők is megjelentek.

A piacok az informális kereskedelem miatt a múltban és jelenleg is részben a nem megfigyelt gazdaság részét képezik (adócsalás, nem megfigyelt import, csempészett áruk kereskedelme). Az alacsony jövedelmű rétegek állandó keresletet jelentenek a termékeik iránt. Ugyanakkor a kormányzat is felismerte, sőt támogatta a fennmaradásukat, hiszen megszüntetésük jelentős feszültségek forrása lett volna.

A piacgazdaság kialakulásával a korábbi második gazdaság összeomlott, ugyanakkor a kiterjedt adócsaló és egyéb nem megfigyelt gazdasági tevékenységek aggasztó mértéküvé váltak. A második gazdaság és a rendszerváltás utáni nem megfigyelt gazdaság egyaránt a szerkezetváltást segítette elő. Míg azonban a második gazdaságban a vállalkozói motiváció ténylegesen megfigyelhető volt, addig a vállalkozások megnövekedett száma a rendszerváltás után nem a piaci integráció korábbi jelentős térnyerésének köszönhető. A jelenség kényszer szülte magatartás, a vállalkozás a foglalkoztatás helyettesítője, az adócsalás szinonimája lett. A kormányzat mindezeket a folyamatokat nemcsak, hogy elnézte, hanem valószínüleg hallgatólagosan támogatta is. Ezzel is erősítve a kormányzattal szembeni bizalmatlanságot. (Sugár \& Trautmann, 1995) 
A piacgazdasági átmenet elősegítése érdekében megalakult 1989-ben az úgynevezett Kék Szalag Bizottság Paul Marer kezdeményezésére. A magyar és nemzetközi közös bizottság számos vizsgálatot végzett és megfogalmazott egy gazdaságpolitikai programot is. A hivatalos statisztikai rendszer szintén átalakulóban volt ebben az időben, a Kék Szalag Bizottság keretein belül a KSH a nem megfigyelt gazdaság becslésben intenzíven közreműködött. (Árvay \& Vértes, 1997/7)

A Kék Szalag Bizottság a korábbi második gazdaság definíciót használta a nem megfigyelt gazdaságra: minden olyan tevékenység számításba vételére törekedtek, amelyek valós társadalmi szükségletet elégítenek ki, azonban nem büncselekmények. (Árvay \& Vértes, 2006) A következő 12. ábra a Kék Szalag Bizottság által becsült nem megfigyelt gazdaság arányokat és a magánszektor súlyát tartalmazza a rendszerváltást megelőző és követő néhány évben.

12. ábra: A magánszektor súlyának és a nem megfigyelt gazdaság arányának alakulása a GDP-hez, viszonyítva, \%

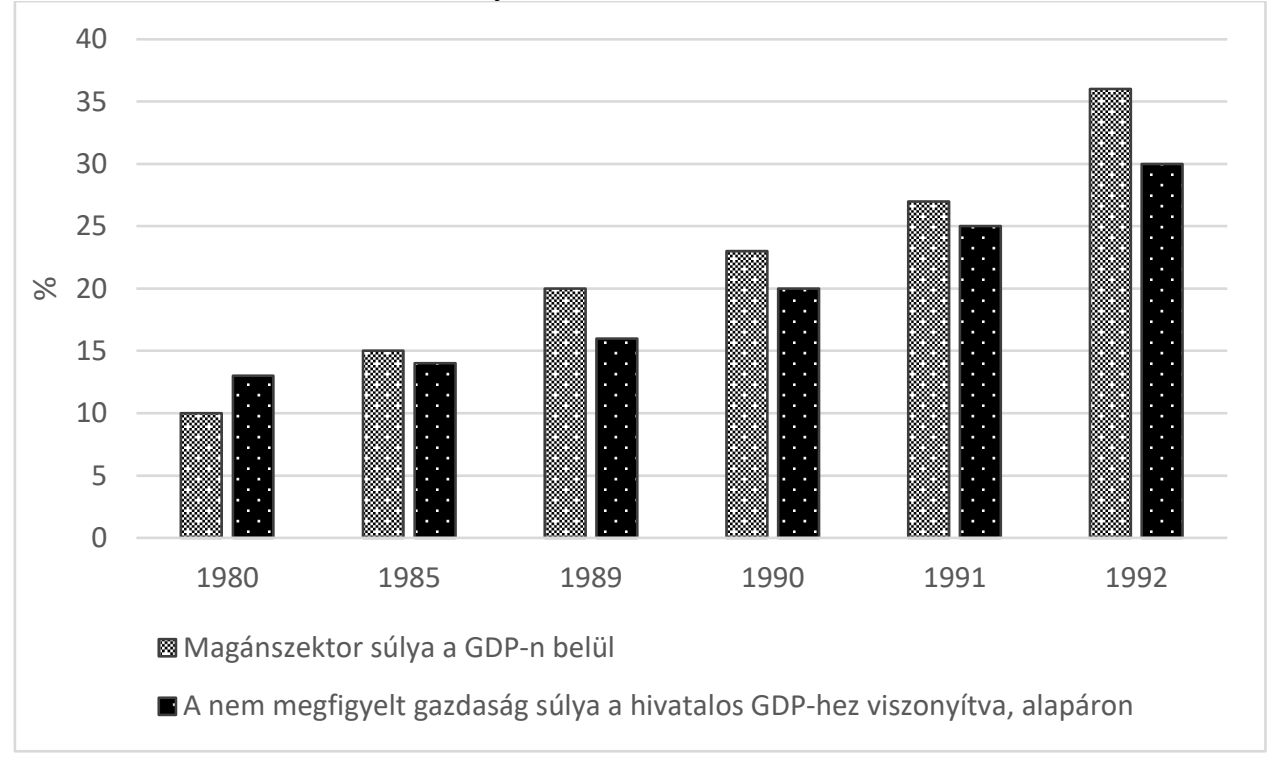

Forrás: (Árvay \& Vértes, 1997/7) alapján, saját szerkesztés

A nem megfigyelt gazdaság aránya 1980-ban a GDP 13\%-át tette ki. A magánszektor növekedésével a nem megfigyelt tevékenységek aránya is emelkedett, Árvay és Vértes szerint 1992-re a GDP 30\%-át érte el. (Árvay \& Vértes, 1997/7)

A rendszerváltás időszaka hosszan elhúzódott. (Kornai, A rendszerparadigma, 1999) A piaci anomáliák, a nem megfigyelt, adóelkerülő és illegális tevékenységek, a szervezett bünözés térnyerése a stabil piacgazdaság normarendszerének kialakulását nem segítette 
elő. Az emberek egymás és a kormányzat iránti bizalma nem mélyült el, sőt, tovább erősödhetett az a benyomás, hogy a kormányzat magukra hagyja az embereket, nehéz helyzetük megoldásáról maguknak kell gondoskodniuk.

\subsubsection{Az áfacsalás visszaszorítására tett intézkedések}

Az ezredforduló után a rendszerváltás időszaka lezárult. A kétezres évek első évtizedében a nem megfigyelt gazdaság aránya csökkent a rendszerváltáshoz képest, 2002-ben a GDP 15,3, míg 2005-ben a GDP 14,9\%-át tette ki. (Murai \& Ritzlné Kazimir, 2011) A 2010es évek előtt a munkabért terhelő elvonások Magyarországon a környező országokhoz viszonyítva meglehetősen magasak voltak. Jelentős mértékü volt a marginális adóék is, amely az adó és járulék növekedését mutatja meg a jövedelemnövekedéshez viszonyítva. (Balog, 2014) Az ezredforduló után az áfacsalás még jellemzően a belföldi számla nélküli értékesítést érintette. (Krekó \& P. Kiss, 2007) Az évtized végére az EU csatlakozás teremtett új lehetőséget az áfacsalás számára, és a kibontakozó pénzügyi válság is adóelkerülésre motiválta a gazdasági szereplőket.

A vizsgált időszak az áfa vonatkozásában is változatos volt. A kormányzat az adópolitikájának megvalósítása során befolyásolni tudja az adózói magatartást számos tényező megváltoztatásával. Ezek az intézkedések érinthetik:

- a kulcsok meghatározását,

- az adminisztrációs kötelezettségek előírását,

- adórendszer egyszerüségét (szabályok értelmezhetősége)

- az állami szabályozást (ide tartoznak például a különböző engedélyezési eljárások, korlátozások)

- az ellenőrzési politikát,

- az adóhatóság és az adózó kapcsolatát,

- valamint egyéb, a gazdasági tevékenységekhez tartozó szabályozási környezetet.

Ezeket a tényezőket a kormányzat közvetlenül befolyásolhatja. A fenti felsoroláshoz azonban hozzá kell még tenni az adómorált és az állam által nyújtott szolgáltatásokkal való általános elégedettséget is. Ez utóbbit a kormányzat közvetve képes befolyásolni. (Balog, 2014)

Az áfacsalásra gyakorolt tényezők hatásainak elkülönítése és a mechanizmusok feltárása nem egyszerü. A gazdasági környezet meghatározza az adózók jövedelmét, piaci lehetőségeit, befolyásolja az adócsalást és az ezzel nyerhető összegek szubjektív értékét. 
Másrészről a szabályozási környezet (adókulcsok, ellenőrzési és büntetési gyakorlat, adminisztratív terhek) közvetlenül meghatározza az adócsalás lehetőségeit. Ugyanakkor az egyes adónemek egymásra is kölcsönösen hatást gyakorolnak. Ilyen például az áfacsalás, amely megteremtheti a forrást a nem bejelentett foglalkoztatásra, és csökkenti a társasági adót is. A nagyon magas jövedelemadó ösztönözheti a nem bejelentett foglalkoztatást vagy pedig a foglalkoztatás alvállalkozói formában történő elszámolását is.

A gazdasági válságból való kilábalással lehetőség nyílt arra, hogy a korábbi torzító, rejtett tevékenységeket ösztönző és versenyképességet rontó intézményi környezet megváltozzon. A kormányzat élt a lehetőségekkel, és foglalkozást érintő intézkedéseket, ill. a kereskedelmet, áfacsalást érintő intézkedéseket is hozott.

A foglalkoztatást érintő intézkedések két csoportba sorolhatók, egyrészt a fekete foglalkoztatás visszaszorítása, másrészt az aktivitási ráta növelése. Az aktivitási ráta növelése három célcsoportra kívánt hatást gyakorolni: a 25 év alattiakra, az 55 év felettiekre, és az anyasági ellátás igénybevétele után a munkapiacra visszatérőkre. A feketefoglalkoztatás visszaszorítása az egykulcsos jövedelemadó és az önfoglalkoztatók kedvezőbb adózási lehetőségeivel (kisadózók tételes adója) valósult meg. (Balog, 2014)

Az áfacsalást és kereskedelmet érintő intézkedések számos területre kiterjedtek.

Az áfakulcsok nagyságának látszólag egyszerü hatása van az adócsalásra. Nagyobb adókulcs esetén nagyobb az adózás miatti „veszteség”, alacsonyabb adókulcs mellett minden egyéb változatlansága mellett kevésbé éri meg a szabálykerülö magatartás. Ez is motiválhatta többek között a 2006. január 1-jei áfakulcs csökkentést 25\%-ról 20\%-ra.

Az áfakulcs változtatásának aszimmetrikus hatása van. A csökkenő áfakulcs hatása sokkal kisebb mértékben hat az árakra, mint a növekvő áfakulcs. Az aszimmetrikus hatás nagyobb mértékben érvényesül az alacsonyabb profitrátájú vállalkozásoknál. (Benzarti, Carloni, Harju, \& Kosonen, 2018) Ez az aszimmetrikus hatás is hozzájárulhatott az áfakulcs csökkentésének kudarcához. Az intézkedés nem váltotta be a hozzá füzött reményeket, ezért 2009. július 1-jétől a 20\%-os áfakulcs helyett 25\% és 18\%-os áfakulcs került bevezetésre. A 25\%-os adókulcsot 2012. január elsejétől tovább emelte a kormányzat $27 \%$-ra. 
Bizonyos termékekre vonatkozólag a későbbiekben a 27\%-os adókulcsot 5\%-ra csökkentették, mint például a sertéshús, a csirke, a tej esetében. Az intézkedést az indokolta, hogy ezeknek a termékeknek a kereskedelme esetén jelentős volt a csalás. (Állami Számvevőszék, 2019)

Az adóregisztráció folyamata szintén az adócsalás lehetőségét csökkentette. Az intézkedés kizárta azt, hogy jelentős tartozást felhalmozó, jogutód nélkül megszünő vállalkozások tulajdonosai, vezető tisztségviselői újonnan alakuló társaságban szerepet vállalhassanak. (Balog, 2014)

2013. január elsejétől életbe lépett a készpénzforgalom korlátozásával kapcsolatos intézkedés. A vállalkozások egymás közti tranzakcióit érinti a rendelkezés, havonta legfeljebb bruttó (áfát tartalmazó) 1,5 millió Ft készpénzforgalom engedélyezett a szerződő felek között. (2003. évi XCII. törvény 38.§ (3) bekezdés)

Az adminisztrációs kötelezettségek szintén befolyásolják az adócsalást. 2012. január elsejétől előírták a közösségi ügyleteknél a tételes összesítő nyilatkozat benyújtási kötelezettségét, ez a közösségben belüli külkereskedelmet tette átláthatóbbá. Az alanyi adómentesség alsó határát 2013. január elsején a korábbi 5 millió Ft-os éves bevételhatárról 6 millió Ft-ra emelték. Szintén 2013-ban vezették be a tételes összesítő jelentést, amelyben partnerenként összesítve kell szerepeltetni mindazokat a tranzakciókat, amelyeknek az áthárított adótartalma meghaladja a 2 millió Ft-ot. Az összeghatárt 2015-ben 1 millió Ft-ra, 2017. július elsejétől 100 ezer Ft-ra csökkentették. Az összesítő jelentés a fiktív számlák elszámolása, és az aszimmetrikus elszámolások csökkentésére vezetett.

Az adóhatóság az adott évi ellenőrzési stratégiáját minden évben közzé teszi „Ellenőrzési irányelvek” címmel. Ebben meghatározza, hogy milyen tevékenységek ellenőrzésére fókuszál az adott évben, és milyen esetekben jelölnek ki automatikusan egy szervezetet ellenőrzésre. A 2015-ös ellenőrzési irányelvek például kiemelte, hogy különösen a nagykereskedelmi tevékenységet folytatók számíthatnak kiemelt figyelemre, tovább az adóhatóság a befogadott valótlan tartalmú számlák kiszürésére fókuszál. (NAV, 2015) 2016-ban az értékesítési láncolatok és számlázási útvonalak feltárásával az áfacsalásokban résztvevők hatékony azonosítása volt a cél. Az EKÁER rendszer adatainak segítségével a virtuális szállítmányok kiszürése is az ellenőrzés célkitűzésévé vált 2016-ban. Ezen kívül a számlaadási kötelezettség teljesítésének előmozdítását 
például a helyszíni ellenőrzések segítségével tervezték elősegíteni. A platform alapú tevékenységek (internetes kereskedelem), továbbá az ún. közösségi gazdaság (sharing economy, például Airbnb) terjedésével az adóhatóság ezekre a területekre is ki kívánta terjeszteni ellenőrzési tevékenységét. (NAV, 2016) Az adóhatóság továbbra is elkötelezett az adócsalás csökkentése iránt. A 2019-re kiadott ellenőrzési irányelvekben megfogalmazták, hogy a jelentős költségvetési kockázatot jelentő adózók ellenőrzésére fókuszálnak, míg a többi adózó esetében a jogkövető magatartás elősegítése a céljuk. (NAV, 2019)

Az adóhatóság és az adózók kapcsolata az elmúlt években megváltozott. Az adóhatóság jelentős lépéseket tett, hogy félelmetes, ellenőrző és büntető hatóság helyett szolgáltató adóhatóságként müködjön, ezzel is ösztönözve az adózók szabálykövető magatartását. A minősített adózói státusz bevezetésére már 2010-2011-ben történt kezdeményezés, azonban a nem megfelelő jogszabályi háttér miatt ez 2012-ben megszünt. (WTSKlient.hu, 2017) A kockázatosnak és megbízhatónak minősített adózó kategóriájának bevezetésére 2016. január elsején került sor a 2003. évi XCII. Adózás rendjéről szóló törvény alapján. Az adózó minősítési eljárását az új 2017. évi CL. Adózás rendjéről szóló törvény is szabályozza a 150-162. paragrafusokban. A 2015. évi CCXXII. törvény pedig egységesen, valamennyi közfeladatot ellátó szerv számára meghatározta az elektronikus ügyintézés biztosításának garanciális jellegü követelményeit. Ez alapján az adóhatóság számára lehetőség nyílt az adóbevallások elkészítésére, így a valódi szolgáltató adóhatóság koncepciójának kialakítására. (Tóth B. , 2019)

$\mathrm{Az}$ áfacsalás visszaszorítása érdekében bevezették a fordított áfa fizetést. Ekkor a kiállított szállítói számlában nem kell szerepeltetni a szolgáltatás áfáját, azt a vevő szerepelteti saját áfa bevallásában. Mivel ilyenkor a vevő nem igényelhet vissza áfát, ezért az ilyen fiktív ügyletek értelmüket vesztik. A fordított áfa 2006. január elsejétől a hulladékkereskedelemre került elsőként bevezetésre, később több termék - többek között mezőgazdasági termékek (gabona, kukorica, repce, sertés), vas- és acéltermékek kereskedelmére, illetve bizonyos építőipari tevékenységekre is kiterjesztették.

Az egyéb intézkedések közül a 2014. szeptember elsejével bevezetett kötelező online pénztárgép használat a kiskereskedelemben, vendéglátásban, kölcsönzésben és háztartási gépjavításban kétségkívül jelentős hatást gyakorolt a szabálykövető magatartásra a számlaadási kötelezettségüket elmulasztók körében. Az adóhatóság ezt követően nyíltan 
hirdette, hogy a tranzakció szintü adatok elemzésével, összehasonlításával, helyszíni ellenőrzésével fogja az adózókat a bizonylatadási kötelezettségükre ösztönözni. (NAV, 2016)

A 2016-ban bevezetett EKÁER rendszer a közúti áruszállítás ellenőrzésével a fiktív és valótlan áruszállítást teszi felderíthetővé. (NAV, 2016)

A fenti intézkedések alapján nyilvánvaló, hogy a kormányzat 2012-től kezdve változatos és jelentős lépéseket tett annak érdekében, hogy az áfacsalást visszaszorítsa Magyarországon. Ehhez az ellenőrzési stratégia átalakítása mellett számos fiskális és adminisztratív terhet befolyásoló, továbbá egyéb, kontrolt és jogkövető magatartást elősegítő intézkedést tett.

Az áfával kapcsolatos fontosabb változások a vizsgált időszakban annyira gyakoriak és sokrétűek volta, hogy azokat a függelékben lévő táblázatban (lásd: 2. függelék: Az áfa fizetést befolyásoló fontosabb intézkedések kronologikus sorrendben) gyüjtöttem össze kronologikus sorrendben.

Egy rejtett gazdasággal kapcsolatot attitüd vizsgálat alapján a lakosság vélekedése szerint a kormányzat nem tesz az adócsalás ellen, szemet huny a csalások felett. Ezt a vizsgálatot a 2010-es évek közepén hajtották végre, amikor a kormányzat már az előzőekben említett intézkedések jó részét elvégezte. Rendkívül érdekes, hogy ezeket az intézkedéseket a lakosság nem érzékelte, vagy nem tartotta hatékonynak. Az is említésre méltó, hogy a lakosság kormányzat iránti bizalma a kérdöíves felmérés szerint még mindig rendkívül alacsony. Bár elítélik az adócsalást és a korrupció különböző formáit, úgy ítélik meg, hogy ezek szükségesek bizonyos esetekben. (Benke \& Karcagi-Kováts, 2017)

\subsection{3. Összefoglaló}

A fejezetben az elmúlt néhány évtizednek a nem megfigyelt gazdaság körébe tartozó jelenségét tekintettem át.

A második gazdaság a szocialista rendszeren belüli összes olyan tevékenységet magában foglalja, amely nem illeszkedik tisztán a szocialista rendszer intézményrendszerébe. A második gazdaság elnevezés azt sugallja, mintha egy egységes és párhuzamos gazdaságról beszélhetnénk a szocialista gazdaság mellett. Azonban a második gazdaság inkább egy gyüjtőfogalom, összetevői széttöredezett, egymáshoz nem integrálódott tevékenységek halmazát jelentik. Ezek a tevékenységek a szocialista rendszerre adott 
racionális válaszok az egyének részéről, amelyeket a kormányzat a rendszer stabilizálása érdekében hallgatólagosan tudomásul vett, vagy támogatott.

A második gazdaság tevékenységeinek jelentős része a szocialista rendszer összeomlását nem élte túl. Azok, amelyek a rendszerváltás után is müködtek, integrálódtak az egyre növekvő magánszektorba, annak csekély részét alkotva. A rendszerváltás során számos olyan tevékenység alakult ki, amelyek csak erre az időszakra voltak jellemzők. Egyrészt az informális kapcsolatokon alapuló tőkefelhalmozás, másrészt a lakosság fogyasztásának részét képező, informális piaci értékesítés térnyerése.

Az adócsalás olyan tevékenységként jelenik meg, amely a korábbi gazdasági rendszerben kevéssé volt jelen. Ezért nem állítom, hogy a jelentős adócsaló tevékenység a második gazdaság rendszerváltás előtti kiterjedt nagyságával magyarázható. Azonban a kormányzat és az egymás iránti bizalom és így a társadalmi tőke nagyságára a szocialista rendszerben megvalósuló kommunikáció, a bizonytalanság és az emberek magukra utaltsága a második gazdaság miatt megvalósuló szabálykerüléssel együtt negatívan hatott. A rendszerváltás tovább erősítette ezt a folyamatot. Az időnként botrányos privatizáció, az életszínvonal csökkenése és a kormányzat tehetetlensége és kommunikációja, a széles körben elterjedt és elfogadott csalás és bünözés tovább csökkentette a társadalmi tőkét.

A kilencvenes években nem megfigyelt tevékenységek a gazdaságot dinamizálták, azonban az ezredforduló után az adócsalás már jelentős társadalmi problémát jelentett. Az adókulcs csökkentése, az ellenőrzések gyakoriságának növelése az ezredforduló utáni első évtizedben nem volt sikeres stratégia. A válság alatt az adócsalás elleni küzdelem kevésbé állt a kormányzati intézkedések homlokterében. A kormányzat 2012-től tett ismét szisztematikus intézkedéseket az áfacsalás visszaszorítására. Ekkortól az adóhatóság a jelentős kockázatot jelentő adózók ellenőrzésére fókuszált, megpróbált pozitív kapcsolatot kialakítani az adózókkal és a kormányzat olyan adminisztratív intézkedéseket hozott, amelyek az adócsalást jelentősen megnehezítették.

\section{Becslési és mérési lehetőségek}

A rejtett gazdaság nem tekinthető homogénnek, mert számos különböző jellegü és motivációjú tevékenységet foglal magában, amit a résztvevők megpróbálnak titokban tartani. A nem megfigyelt gazdaság mérése, becslése problematikus. A mérhetőség 
problémájával foglalkozik például Cserháti és szerzőtársai könyve is. (Cserháti, és mtsai., 2009) Nem található olyan közös ismérv, ami minden nem megfigyelt jelenségre jellemző lenne, érdemes legalább valamilyen fontos tényező szerint részekre bontani a tevékenységeket.

A kategorizálás többféle ismérv alapján történhet. Az „Adócsalás a nemzeti számlákban” alfejezetben bemutattam az Eurostat és az OECD kategória rendszerét (lásd: 1. táblázat). A nemzeti számlák összeállítása során az Eurostat kategória rendszerét kell követni, az áfacsalás ebben a rendszerben az N6, „A hivatalos nyilvántartásokból torzított adatközlés miatt kimaradó gazdasági teljesítmény” kategóriába kerül.

A szándékosan torzított adatszolgáltatás miatt nem megfigyelt termelés becslésére az Eurostat számos módszert javasol:

1. Munkainput módszer

2. Forrásfelhasználás alapú becslés

3. Szakértői becslések

4. Adó és vám, munkaügyi stb. ellenőrzések adatai

5. Teoretikus és ténylegesen befizetett áfa

6. Egyedi, illetve rendszeres adatgyüjtések. (Eurostat, 2005)

A fejezet ezeket a módszereket ismerteti, továbbá áttekinti a többi, nem megfigyelt gazdaság becslésére használt eljárást is. A fejezet főként Murai és Ritzlné 2011-es tanulmányára épül. (Murai \& Ritzlné Kazimir, 2011)

\subsection{Aggregátumokat felhasználó módszerek}

Bizonyos, makrogazdaságra jellemző aggregátumok tartalmazzák a rejtett gazdaság hatását, míg más aggregátumokból ez kimarad. Továbbá, ha a vizsgálatok szerint ezeknek az egymáshoz viszonyított változása eltér a feltételezhető szabályszerüségtől, akkor ez a nem megfigyelt tevékenységek arányának változását jelenti.

\subsubsection{Makromodellek alkalmazása}

A legismertebb módszer Vito Tanzi nevéhez füződik, a készpénzkereslet és a GDP arányának alakulását elemzi. Feltételezi a készpénzkereslet és a GDP rögzített arányát, és azt, hogy a rejtett gazdaságban leginkább készpénztranzakciókat hajtanak végre. Ezért a készpénzkereslet és GDP arányának változása a rejtett tevékenységek GDP-n belüli súlyának változását jelenti. (Tanzi, 1980) Más aggregátumokat szintén lehet a rejtett 
tevékenységek becsléséhez proxyként használni. Az elektromosáram-fogyasztás GDP-re vetített arányának emelkedése a rejtett gazdaság arányának növekedésére utal (Lackó, 2000). Az elektromos áram proxyként történő szerepeltetése néhány területen gondot okozhat. Idővel az áramfogyasztás a technológia fejlődése miatt változhat, emellett az áramfogyasztás GDP szerinti rugalmassága szintén nem tekinthető állandónak, ráadásul nem minden rejtett tevékenység jár áramfogyasztással (Schneider, 2002). A kormányzati kiadások szintje szintén használható proxyként, ha feltételezhető, hogy a kormányzat ismeri a rejtett jövedelmeket és azok eloszlását. (Bhattacharyya, 1999) Ilyen eset lehet például, amikor az egészségügyi dolgozók bérének rendezésekor a lehetséges hálapénzt figyelembe veszik (a szülészorvos fizetése alacsonyabb, mint a gyermekorvosé, lásd a 2.3.1.3 A hálapénz címü alfejezetet). A háztartások tartós fogyasztási javak iránti keresletének alakulása szintén proxynak tekinthető, ha feltételezhetjük, hogy együtt mozog a rejtett tevékenységek alakulásával. Ezek az összefüggések valószínűleg nem tekinthetők általános érvényünek, erősségük függ az adott ország sajátosságaitól.

Jelenleg az áfacsalás az Európai Unióban legjelentősebb forrása a közösségen belüli kereskedelem, ezért az import és export is használható proxyként. (Frunza, 2020)

Az aggregátumokat használó becslési módszer csak a rejtett gazdaság dinamikáját képes meghatározni. A nem megfigyelt tevékenységek szintje csak egy referenciaérték kijelölése után számítható ki, amely lehet akár nulla, vagyis a becslések feltételezhetnek egy évet, amikor nem volt rejtett tevékenység (Ahumada, Alvaredo, \& Canavese, 2006).

Az elmondottakat illusztrálandó modell Ahumada, Alvaredo és Canavese cikkéből származik, és a nem megfigyelt gazdaság méretének becslésére mutat be egy pénzkeresleten alapuló módszert. Az alapfeltevés az, hogy a vizsgált időszakban a pénz forgási sebessége állandónak tekintendő, illetve a megfigyelt és nem megfigyelt gazdaságban azonos.

A modell a pénzpiac egyensúlyára épül, amelyből ismert a pénzmennyiség, amit a megfigyelt és nem megfigyelt gazdaságban együttesen használnak. Ezután a megfigyelt gazdaság pénzkeresletét a regisztrált gazdaság GDP-szintjét és a pénztartás alternatív költségét felhasználva számítják ki. A pénzkínálat így felosztható a pénz felhasználása szerint rejtett és megfigyelt pénzkeresletre. Ha feltesszük, hogy a megfigyelt és nem megfigyelt gazdaságban azonos a pénz forgási sebessége, akkor ez a mutató kiszámítható a megfigyelt gazdaságról ismert adatok alapján, és segítségével meghatározható a rejtett 
GDP. ${ }^{10}$ Az eljárás a nem megfigyelt gazdaság legfontosabb motivációjának az adók és adminisztratív eljárások elkerülését tekinti, amihez a készpénzforgalom elengedhetetlen. A modell kiinduló összefüggése a mennyiségi pénzelmélet alapegyenlete, amely a pénzkereslet és pénzkínálat egyenlőségét fejezi ki:

$$
M V=P Y
$$

ahol $M$ a pénzmennyiség a látra szóló betéteket is beleértve (ez az úgynevezett szűken vett pénz, amelyet M1-gyel is jelölnek), $V$ a pénz forgási sebessége. A jobb oldalon álló $P Y$ pedig a tranzakciók értékét jelenti, $P$ az árszínvonal, $Y$ pedig a GDP reálértéke. A becslési eljárást kiegészíti még a pénzkereslet ökonometriai becslése is. A pénzkeresleti függvény $\left(C_{0}\right)$ általános alakja a következő:

$C_{0}=A(1+\Theta)^{\alpha} Y_{0}^{\beta} \exp (-\gamma i)$

ahol $\Theta$ jelenti a rejtett gazdaságban való részvételre ösztönző tényezőket magában foglaló változót; $Y_{0}$ egy skálaváltozó (például a megfigyelt gazdaságra vonatkozó GDP vagy a tranzakciók értéke); a pénztartás alternatív költsége i, ami lehet a kamatláb vagy inflációs ráta is. Az $A, \alpha, \beta, \gamma$ pozitív paraméterek, amelyek közül az $\alpha$ és a $\beta$ a pénzkereslet rugalmasságát fejezik ki a rejtett gazdaságra ható indikátorok, illetve a GDP (jövedelem) szerint; $\gamma$ a kamatláb pénzkeresletre gyakorolt hatásának erősségét mutatja meg. A pénzkeresletet $\left(C_{0}\right)$ feloszthatjuk a regisztrált és a rejtett tranzakciókra felhasznált részre. $C_{0}=C_{R}+C_{H}$

ahol $C_{R}$ a regisztrált tranzakciókhoz, míg $C_{H}$ a rejtett tranzakciókhoz szükséges pénzmennyiség. A pénzkereslet a regisztrált tranzakciókra a következő összefüggéssel becsülhető:

$\hat{C}_{R}=\hat{A} Y_{R}^{\widehat{\beta}} \exp (-\hat{\gamma} i)$

ahol $Y_{R}$ a regisztrált tevékenységekböl megtermelt GDP-t jelenti. Ekkor a rejtett gazdaságban való részvételre ösztönző tényezőket nem kell figyelembe venni. ${ }^{11} \mathrm{~A}$ rejtett

\footnotetext{
${ }^{10}$ A feltételt a becslési eljárás működőképességének érdekében kevésbé általánosan is ki kell mondani - a korai pénzkeresleten alapuló modellek szerint. A pénz forgási sebességének a megfigyelt és a nem megfigyelt gazdaságban egyenlőnek kell lennie. Ez csak akkor lehetséges, ha a pénzkereslet jövedelemrugalmassága egységnyi (Ahumada, Alvaredo, \& Canavese, 2006), (Giles, 1999).

${ }^{11} \mathrm{Ez}$ a feltételezés szintén leegyszerüsítés, hiszen a növekvő ösztönzés a rejtett gazdaságban való részvételre biztos, hogy csökkenti a regisztrált gazdasági aktivitást.
} 
gazdaság pénzkereslete megbecsülhető a teljes pénzkereslet és a regisztrált tranzakciókhoz szükséges pénzkereslet különbségeként:

$\hat{C}_{H}=C_{0}-\hat{C}_{R}$

A pénz forgási sebessége kiszámítható a megfigyelt GDP és a megfigyelt tranzakciókhoz szükséges pénzmennyiség hányadosaként úgy, hogy a pénzpiac egyensúlyát feltételezzük:

$\widehat{V}_{R}=\frac{Y_{R}}{\hat{C}_{R}}$

Az alapfeltevések között szerepel, hogy a pénz forgási sebessége a regisztrált és nem regisztrált gazdaságban azonos, így igaz a következő összefüggés:

$\widehat{V}_{R}=\frac{\widehat{Y}_{H}}{\hat{C}_{H}}$

ahol $\widehat{Y}_{H}$ a rejtett gazdaságban előállított GDP-t jelenti. Az előző összefüggésből pedig megkaphatjuk a rejtett gazdaságban megtermelt GDP-t:

$\hat{Y}_{H}=\widehat{V}_{R} \hat{C}_{H}$

A modell és becslési eljárás müködőképességének az a feltétele, hogy a pénzkereslet jövedelemrugalmassága, vagyis a $\beta$ paraméter értéke egységnyi legyen (Ahumada, Alvaredo, \& Canavese, 2006).

A rejtett gazdaság pénzkeresleten alapuló megközelítése egyéb modellezési technikáknál kiegészítésként szolgálhat arra, hogy segítségével a rejtett és megfigyelt gazdaság arányát hosszú távon becsülni lehessen. Az így meghatározott rejtett gazdaság szint viszonyítási alapként használható (Giles, 1999).

Az aggregált makrogazdasági adatok felhasználásával becsült rejtett gazdaság értékeket a nagyon szigorú feltevések miatt óvatosan kell kezelni. Természetesen bizonyos feltételek feloldhatók, ám így a modell bonyolultsága, ugyanakkor megbízhatósága is növekszik. Az eljárás sajátosságai miatt azonban a nem megfigyelt gazdaság szintjét csak egy referenciaértékhez képest határozhatjuk meg és kizárólag a pénzügyi tranzakciók becsülhetők a segítségével. A nehézségek ellenére a modell egyszerü, könnyen használható, bár a nyolcvanas évektől kezdve veszített a népszerüségéből, még napjainkban is számos becslésnek ez az alapja. 
Az áfarésre Zidková illesztett modellt, ahol az azt befolyásoló tényezőket térképezte fel. Két évre, 2002-re és 2006-ra illesztett modelleket. Eredményei szerint a relatív változók, mint a közösségen belüli kereskedelem, az áfa bevételek aránya a GDP-hez, az áfakulcsok száma, illetve a háztartások végső fogyasztási kiadásán belül a vendéglátás és a szálláshelyszolgáltatás aránya, végül a végső fogyasztás GDP-hez viszonyított aránya határozza meg az áfarés nagyságát. (Zidková, 2014)

\subsubsection{A nem megfigyelt gazdaság, mint látens változó}

A modellcsalád kialakításának alapgondolata az, hogy nem megfigyelt gazdaság látens változóként kezelendő, hiszen nem mérhető. Ugyanakkor a jelenség számos tényezővel kapcsolatba hozható, amelyek egy része ok, más része a jelenség következménye. A MIMIC- (multiple causes and multiple indicators) és DYMIMIC- (dynamic multiple causes and multiple indicators, a MIMIC dinamikus formája) modellek a rejtett gazdasági aktivitás kiváltó okait és a rejtett tevékenység hatását tartalmazó indikátorok között teremtenek kapcsolatot úgy, hogy elöször a rejtett tevékenység szintjét becsülik annak okaival, majd a következményeket a rejtett tevékenység látens változójával. Az alapmodellt Jöreskog dolgozta ki (Jöreskog, 1969). A nem megfigyelt gazdaság becslésre 1984-ben illesztették az első modelleket. (Frey \& Pommerehne, 1984) (Frey \& WeckHannemann, 1984)

A MIMIC és a DYMIMIC modellek a SEM (structural equation modelling) modellkategóriába sorolható modelltípusok, amelyek becslése faktor analízisre és regressziós számításokra épül. A felépített modell szerkezete a változók közti strukturális kapcsolatok elemzését teszi lehetővé. A MIMIC-modellek eleinte az átlagos és határadórátát, a reguláció szintjét és az inflációs rátát használták exogén változóknak. A későbbi modellek a férfi munkaerö állományát és a készpénz, pénzkínálat hányadost is bevették az exogén változók sorába. A látens változóból - ez többek között a rejtett kibocsátás outputja is lehet - számos endogén változó számítható ki (Giles, 1999). Természetesen a MIMIC-modellel kapcsolatban is számos kritika merül fel. Az exogén változók kiválasztása sok esetben nélkülözi a kellő magyarázatot. Ezen kívül a látens változó becslése nem stabil, vagyis az érintett országok körének és az idősor hosszának kismértékü változására is érzékenyen reagál (Breusch, 2005).

Ugyanakkor Friedrich Schneider DYMIMIC modellel az országok jelentős körére becsül nem megfigyelt gazdaságot hosszú ideje, becsléseit rendszeresen publikálja, az így 
készült hosszú idősort a 13. ábra mutatja meg. (Medina \& Schneider, 2017) (Schneider, 2002)

Friedrich Schneider több éve becsüli számos országban a rejtett gazdaság (az általa használt kifejezés a shadow economy) alakulását. Az általa használt fogalom nem teljesen azonos azzal, amit Árvay és Vértes használt (Árvay \& Vértes, 1997/7) azonban becslése a nem megfigyelt jelenségek hosszú távú alakulásáról nyújthat információt. A magyarországi shadow economy GDP-hez viszonyított arányának alakulását a 13. ábra mutatja be.

\section{3. ábra: A rejtett gazdaság (shadow economy) GDP-hez viszonyított arányának alakulása Schneider becslése alapján, \%}

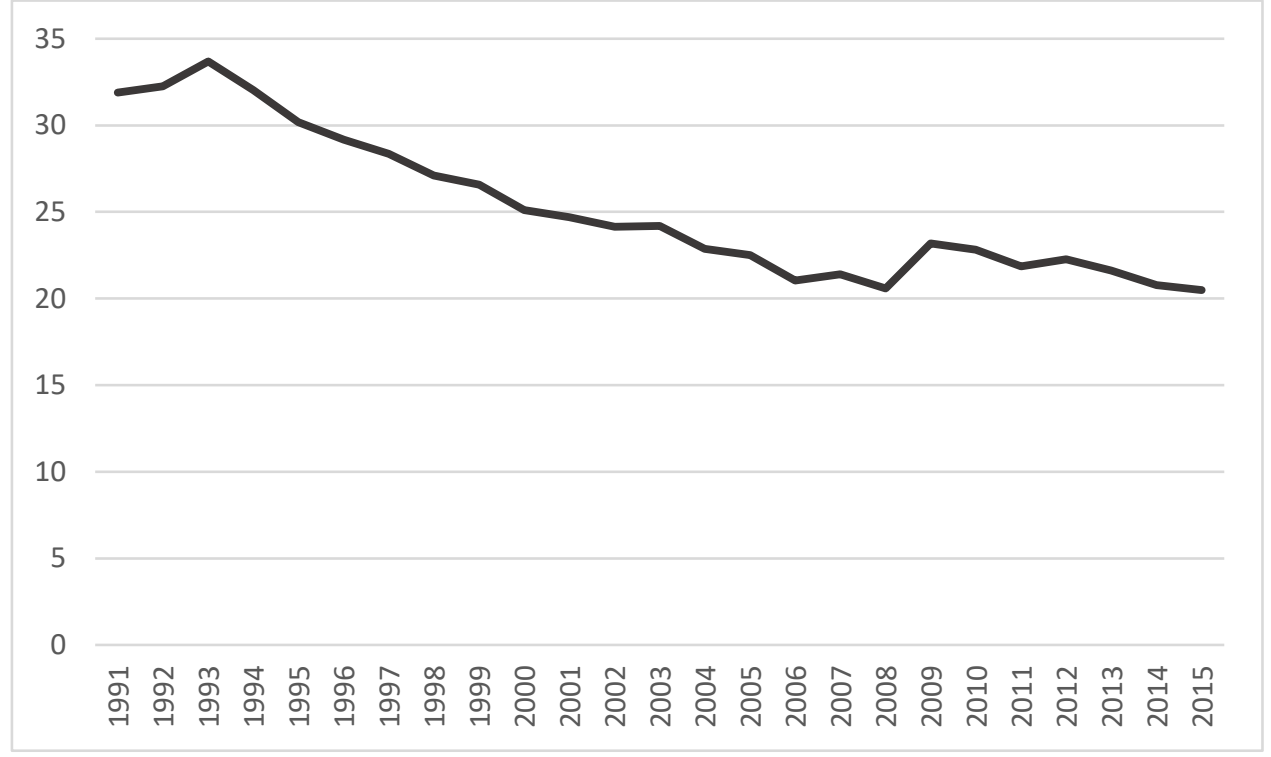

Forrás: saját szerkesztés (Medina \& Schneider, 2017) alapján

Medina és Schneider becslése 1991-re jelentősen, 1992-re kis mértékben eltér Árvay és Vértes számításaitól (31,9 és 25, illetve 32,3 és $30 \%$ ), amelyet a 12. ábra mutat be. Bár Medina és Schneider becslése makromodellen alapul, azért mégis támpontot adhat a tendenciákról. Számításaik szerint a rejtett tevékenységek GDP-hez viszonyított legmagasabb aránya 1993-ban volt megfigyelhető, ekkor az arány meghaladta a 33\%-ot. Ezt követően az arány folyamatosan csökkent egészen 2008-ig. 2009-ben jelentősen megnő, és 2015-ben éri el újra a 2008-as szintet. 


\subsection{Input-output struktúrákon alapuló módszerek, normák}

\section{alkalmazása, alulról felfelé építkező módszerek (bottom-up)}

A nemzetgazdaság teljesítményének különböző dimenzióiról eltérő adatállományok állnak rendelkezésre. Az ezekből számított arányok, eltérések elemzése szintén lehet a nem megfigyelt gazdaság becslésének az alapja. Ebbe a számítási körbe számos módszer tartozik, ezek közül a Commodity flow eljárást, a normák alkalmazását, a bottom-up módszereket és az áfarés számítást mutatom be vázlatosan.

\subsubsection{A Commodity flow eljárás}

A commodity flow eljárás alapja, hogy nemzetgazdasági szinten a források és a felhasználások megegyeznek minden lehetséges termékre, ágazatra és szektorra vonatkozóan. Kicsit részletesebben ez azt jelenti, hogy minden szektort, ágazatot és terméket tekintve egyenlő a hazai összes kibocsátás és import összege (az összes forrás), a háztartások, a kormányzat és a háztartásokat segítő nonprofit szervezetek végső fogyasztásának, a felhalmozásnak és az exportnak az összegével (összes felhasználás). A rendelkezésre álló adatok ilyen felbontásban általában nem igazolják az egyenlőséget. A részletes elemzésnek fel kell tárnia az eltérések okait, amelyek közül számos a rejtett gazdaság tevékenységéből eredhet.

A módszer nem aggregátumok szintjén, hanem részleteiben tárja fel a rejtett gazdaság tevékenységével érintett területeket, melyek struktúrája, valamint a látens és megfigyelt gazdaság kapcsolata és alakulása ezzel a technikával jól felderíthető.

Mivel a módszer az input-output modellek elemzési eszközeit használja, ezért segítségével megállapítható az egyes tevékenységek rejtett gazdaság igényessége, az input-output modellekben használt egyéb tényezőigényességi mutatókhoz hasonlóan.

\subsubsection{Normák alkalmazása}

A normák elemzését felhasználó módszertan az egyes tevékenységek erőforrásigényességét becsüli (általában valamilyen szakértői becsléssel), és ezzel hasonlítja össze a ténylegesen rendelkezésre álló megfigyelt adatokat. A legkézenfekvőbb normának a folyó termelőfelhasználás és bruttó kibocsátás hányadosát tekinthetjük. Az eljárás használhatóságának van néhány feltétele, amelyek szigorúsága behatárolja a becslési módszer hasznosíthatóságát. Az arányon alapuló számítások csak akkor alkalmazhatók, ha feltehetjük, hogy a nem megfigyelt gazdaságot is tartalmazó valamely adatunk közül legalább egy megbízhatónak tekinthető. Másik fontos feltétel, hogy csak homogén 
termékeket, tökéletesen versenyző piaci környezetben elöállító termelők esetén alkalmazható az eljárás. Végül harmadikként kell megemlíteni, hogy változó piaci feltételek mellett (például növekvő kereslet) eltérhet az iparág és az egyes vállalatok kibocsátása is. Az állandó hányados viszont csak akkor alkalmazható, ha azonos a technológia, és állandó a termelés egységköltsége (Belyó, A rejtett gazdaság természetrajza, 2008).

\subsubsection{Bottom-up (alulról felfelé építkező) módszerek}

Bottom-up módszerek esetében valamilyen mikroszintű - általában közvetlen megkérdezésből származó - adatsor összesítésével végeznek becsléseket aggregált mutatókra. Az alulról építkező, direkt módszerek közé tartozik a diszkrepanciaelemzést, amelynek egyik fajtája a munkainput módszer (Labour Input Method), ami a vállalati munkaerő-felmérés és a háztartási megkérdezésből eredő munkaráfordítás összehasonlítása. Más módszerrel a KSH munkaerő-felmérésének és az Országos Egészségbiztosítási Pénztár, illetve Országos Nyugdíjbiztosítási Főigazgatóság adatállománya alapján a bejelentett foglalkoztatásnak a különbsége.

Másik lehetséges módszere a lakossági felmérések alapján becsült személyi jövedelemadó vagy áfa és az adóhatósághoz ténylegesen befolyt adók összehasonlítása. A számítások felhasználhatóságát az adórendszer bonyolultsága csökkenti (Elek, Scharle, Szabó, \& Szabó, 2009), (Belyó, 2008). A legegyszerübb diszkrepanciaelemzés a rejtett gazdaság méretére vonatkozóan a GDP termelési és kiadási oldalának összehasonlítása. A termelési oldalon számításba vett szereplőknek érdeke, hogy aktivitásukat eltitkolják, ezért a felhasználási és termelési oldalról számított GDP különbsége a rejtett tevékenységek szintjének tekinthető. Az érték csak akkor lenne pontos, ha a két oldalról számított GDP esetén nem kellene semmiféle hibával, eltéréssel számolni. A másik gond az, hogy számos esetben a termelési oldalról számított GDP nagyobb, mint a felhasználási oldali, mégsem mondhatjuk, hogy nincs a vizsgált országban rejtett gazdasági tevékenység (Elek, Scharle, Szabó, \& Szabó, 2009). A „bottom-up” módszerek közé tartoznak a szakértői becslések is. A közvetlen megkérdezések alkalmasak arra, hogy az elemzők árnyalt képet alkothassanak az érintettek attitűdjeiről, megoszlásáról, illetve a fehér és fekete gazdaság arányának változásáról a piaci szereplők döntéseinek függvényében (Belyó, 2003) (Belyó, 2004); (Fazekas, 2009). A makroszintü következtetések a becslés eredményeiből nehezen vonhatók le. Problémát okozhat még az is, hogy a résztvevők válaszát befolyásolhatja a kérdező személye, a kérdésfeltevés 
módja, illetve az, hogy mennyire értik meg a válaszadók a kérdést. A megfigyelésekből adódó eredményekre modellek is építhetők, amennyiben több időszakon keresztül megismétlik a megkérdezést ugyanazokkal a kérdésekkel, valamilyen szempontból hasonló válaszadói körrel. A válaszok változására így a külső körülmények változásában találhatnak magyarázatot. Ez történt a Semjén és Tóth tanulmányában ismertetett elemzésben is. Az eredmények alapján arra a következtetésre jutottak, hogy a rossz kormányzati szereplés, az adórendszer bizonytalansága és a korrupció érzékelése növeli a rejtett gazdaságban való részvételt. (Semjén \& Tóth, 2009)

Az áfacsalás becslésére is alkalmazhatók bottom-up módszerek, mint például a közösségen belüli kereskedelem során megvalósuló csalás (Missing Trader IntryCommunity fraud MTIC fraud). A módszer országonként vizsgálja az import statisztikákat, és ezeket összeveti az exportáló ország export statisztikáival. Az összehasonlítás során figyelembe kell venni, hogy az importot és az exportot eltérő paritáson számolják el a külkereskedelem statisztikában. (Gradeva, 2014)

Ugyanakkor az áfacsalás elkövetői rugalmasan reagálnak a körülmények változására, az áfacsalás átszövi a külkereskedelemben résztvevő termékek széles skáláját. A külkereskedelemben lévő különbségeket egyéb okok is eredményezhetik. Ezért az export és import statisztikák összevetésével az áfacsalás mértékéről nem készíthető jó becslés. (Borselly, 2011)

\subsubsection{Az áfarés számítása}

Az áfarés a teoretikus áfa és a ténylegesen befolyt áfa bevételek különbsége. A teoretikus áfa az az összeg, amely akkor folyna be a költségvetésbe, ha a minden tranzakció után megfizetnének a jogszabályban meghatározott áfát.

Az áfarés kiszámítása azért bonyolult, mert az áfatörvény alapján az áfakulcs termékenként eltérő lehet, tovább vannak olyan termékek, amelyeknek az értékesítése során nem számítanak fel áfát. Az áfa a háztartások, kormányzat és nonprofit szervezetek végső fogyasztási célú vásárlásaiban jelenik meg, hiszen ők nem igényelhetik vissza az áfát. Mindemellett az alanyi adómentességet választó vállalkozások sem igényelhetnek vissza áfát, emiatt a beruházások (bruttó állóeszközfelhalmozás) és a folyó termelöfelhasználás tételei is tartalmaznak vissza nem igényelhető áfát, kisebb mértékben. 
Az áfarés elméletileg az összes áfacsalást magában foglalja, tehát az így kiszámított áfacsalást még érdemes szétválasztani a közösségen belüli, közösségen kívüli és hazai nem megfigyelt gazdaság hatására. Az utóbbi években az áfacsalás jelentős része a közösségen belüli külkereskedelem során realizálódott, az áfarés és az import közti kapcsolat kimutatható. (Frunza, 2020)

Az áfarést a nemzeti számlák adatai és a nemzeti számlákra épülő termékbontású forrás és felhasználás tábla adatai alapján lehet kiszámolni. A forrás és felhasználás tábla adatai CPA (Statistical classification of products by activity) bontásban állnak rendelkezésre 59 termék és szolgáltatás csoportra, általában a vonatkozási időszak után 2-3 évvel. Magyarországon a vonatkozási év utáni harmadik évben publikálja a KSH a hazai forrás és felhasználás táblákat.

A felhasználás tábla a felhasználási tételeket tartalmazza termékbontásban. Az első blokkja a folyó termelőfelhasználás adatok mátrixa, ahol a termelő szervezetek TEÁOR (Gazdasági tevékenységek egységes osztályozási rendszere 2008) szerinti bontásba (59 ágazat) vannak sorolva. Utána következnek a végső felhasználás tételei, a háztartások, háztartásokat segítő nonprofit szervezetet és a kormányzat végső fogyasztási kiadása. Ezt követi a bruttó felhalmozás, ami a bruttó állóeszközfelhalmozás, az értéktárgyak vételének és eladásának egyenlege, és a készletváltozás tételeket tartalmazza. Végül az export bontása következik a kivitel iránya szerint EU és nem EU-ba irányuló exportként (lásd 1. függelék).

A teoretikus áfát a következő felhasználási tételekre számítják ki:
a. háztartások végső fogyasztási kiadásai
b. háztartásokat segítő nonprofit szervezetek végső fogyasztási kiadásai
c. kormányzat végső fogyasztási kiadásai
d. bruttó állóeszközfelhalmozásra jutó, vissza nem igényelhető áfa
e. folyó termelőfelhasználásra jutó, vissza nem igényelhető áfa.

A felhasználási tételekre külön-külön számítanak ki átlagos áfa rátákat. Amennyiben az 59 termékcsoportos bontásban van olyan termékcsoport, amelybe eltérő áfa kulccsal adózó termékek vannak, akkor becslést készítenek azok súlyáról a felhasználási tételen belül. 
A termelő szervezetek különböznek egymástól abból a szempontból, hogy visszaigényelhetik-e az áfát. A visszaigényelhetőség függ a szervezetek tevékenységétől, a kibocsátásától és a méretétől. A visszaigényelhető áfa arányát ágazatonként kell kiszámítani. A számítások során azt is figyelembe kell venni, ha az ágazat vegyesen áfa mentes és nem mentes tevékenységeket is tartalmaz. Ez az arány közvetlenül a nemzeti számlákból nem kiszámítható, ezért ehhez a Háztartási Költség Felmérést és az SBS (Structural Business Statistics, éves gazdaságstatisztikai adatgyüjtés) felmérés adatait használják fel. Azzal a feltételezéssel élnek, hogy a vegyes (áfa mentes és nem mentes tevékenységeket is tartalmazó ágazatok) tevékenységek esetében a mentes tevékenység kibocsátásának aránya az összes kibocsátáshoz viszonyítva megegyezik mentes tevékenység folyó termelőfelhasználás arányával az összes folyó termelőfelhasználáshoz viszonyítva.

Végül néhány kiigazítás szükséges, ami az áfa kötelezettséget növelheti:

- visszaigényelhető áfa korlátozása miatt a reprezentációs költségek esetében

- visszaigényelhető áfa korlátozása a céges gépjármüvek vásárlása esetén

- áfa alanyiság határa alá eső vállalkozások vissza nem igényelhető áfája

- „tankolási turizmus” Luxemburg esetében például - sok külföldi vállalkozás Luxemburgban tankol, és az áfát nem igényli vissza. (Reckon, 2009)

Végül fel kell hívni a figyelmet arra, hogy az áfarés nem az áfacsalás mérőszáma, legfeljebb proxy-ként használható fel az áfacsalás alakulására, hiszen az áfarés a következő tényezőkre vezethető vissza.

- csalás miatt be nem fizetett áfa

- legális adóoptimalizálás miatt be nem fizetett áfa

- fizetésképtelenség miatt nem teljesített áfa fizetési kötelezettségek

- nemzeti számlák megfelelő minősége és teljessége miatti eltérések

A túl magas áfarés a legális adóelkerülés miatt be nem szedett áfa jelentős nagyságára utal. Ha az áfarés nagyon alacsony, akkor következtethetünk arra is, hogy a nemzeti számlák mutatói nem teljesek, nem tartalmaz minden fogyasztási és termelési kategóriát. Ebben az esetben a nemzeti számlák számlasorozata nem mér minden aktivitást. (Reckon, 2009) 
Keen és Smith felhívja a figyelmet arra, hogy a kereslet alapú áfacsalás becslések, mint a teoretikus és az áfarés becslés nem alkalmasak a szintek becslésére, az eredményekből csak a változásokra lehet következtetni. A szintek meghatározásához inkább a bottom-up módszerek alkalmasak. (Keen \& Smith, 2007)

Az áfarés keresleti oldali számításával kapcsolatban ki kell emelni, hogy a magas áfacsalás az egymással külkereskedő országok áfacsalására is hatással lehet. Például Albánia esetében a magas export arány Törökországba, ahol nagyon magas az adócsalás aránya az áfacsalás importját okozza Albániába. (Shahini \& Malaj, 2015)

A nemzeti számlákkal szemben támasztott követelmény az időbeli homogenitás, valamint a tagországok közötti összehasonlíthatóság, ami miatt a nemzeti számlák adatai rendszeresen adat és módszertani revízióknak vannak alávetve. Ebböl kifolyólag a nemzeti számlák mutatói szigorú értelemben véve soha nem lesznek véglegesek. A vonatkozási időszaktól egyre távolabbra kerülve az adott év adataiban egyre több olyan tétel jelenhet meg jogszabályi előírások változásának hatására, amelyeket a nemzeti számlák az első publikációkor még nem tartalmaztak, és amelynek a visszavezetett értéke valamilyen becslésen alapul. (Példaként megemlíthetjük a pénzügyi közvetítés közvetetten felszámított díjának (FISIM) bevezetését 2006-ban (KSH, 2006)) A nemzeti számlák változásával párhuzamosan az áfarés becslések időben jelentős mértékben változnak az egyes vonatkozási időszakokra.

A forrás és felhasználás táblák a visszavezetett, homogén idősorokra nem minden országra állnak rendelkezésre. Például Magyarország esetében 2020. februárjában a 2018-as módszertan szerint áll rendelkezésre a forrás és felhasználás táblarendszer a 2010-2014 évekre, 2015-2016-ra pedig a 2019-es módszertan szerinti elérhető. Az áfarés számításnál az áfarés visszavezetés esetében az új forrás és felhasználás táblákat használják a visszavezetéshez. (Európai Bizottság, 2018)

Úgy vélem, hogy adott vonatkozási évre a legelső megjelentetett áfarés becslés tükrözi leginkább a be nem fizetett áfa nagyságát. Ezen adatokból összeállított idősor látható a következő ábrán. 
14. ábra: Az áfarés alakulása az Európai Bizottság becslés alapján, a teoretikus nettó áfa százalékában

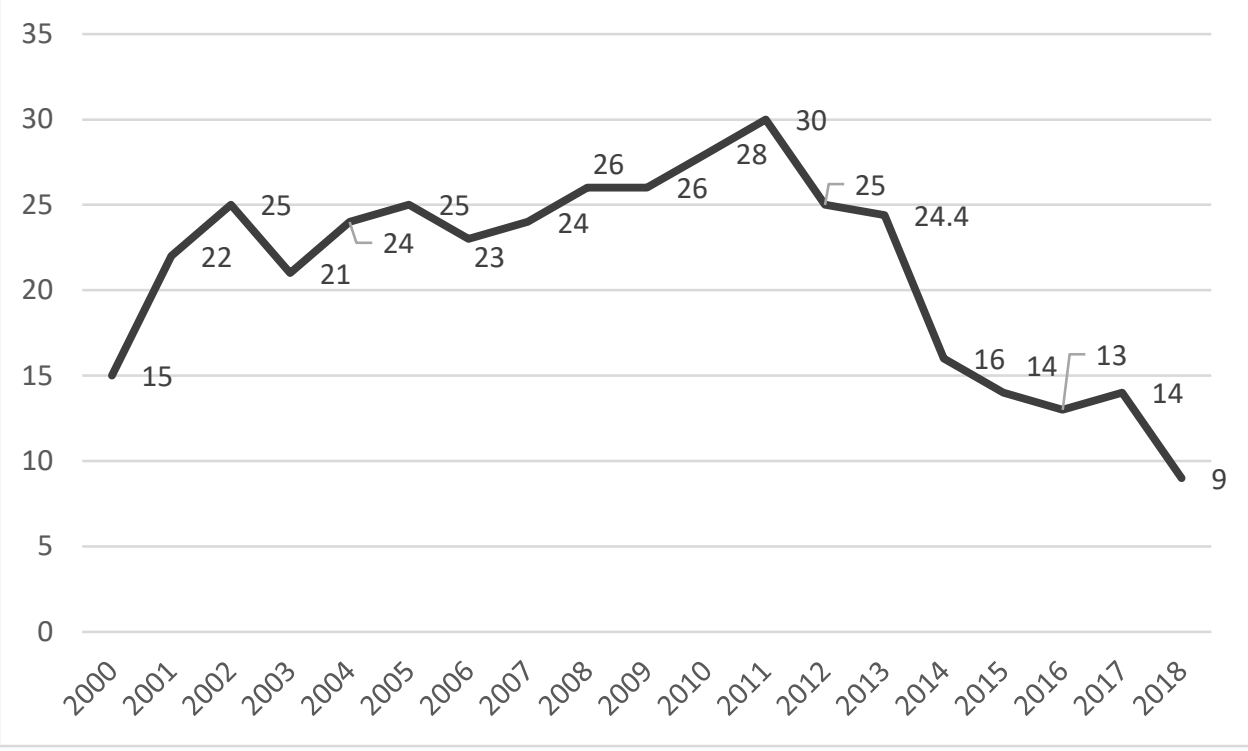

Forrás: saját szerkesztés (Reckon, 2009) Európai Bizottság (2012-2019) alapján

A 14. ábra alapján az áfarés a 2000-es 15\%-ról 2011-re 30\%-ra emelkedett. Utána drasztikusan csökkent, legnagyobb mértékben 2014-re. Az áfarés csökkenésének több oka is lehet, a gazdasági növekedés, az effektív áfakulcs változása és az áfa fizetések teljesítésének a változása.

15. ábra: Az áfarés 2016-ban az Európai Unió tagállamaiban (\%)

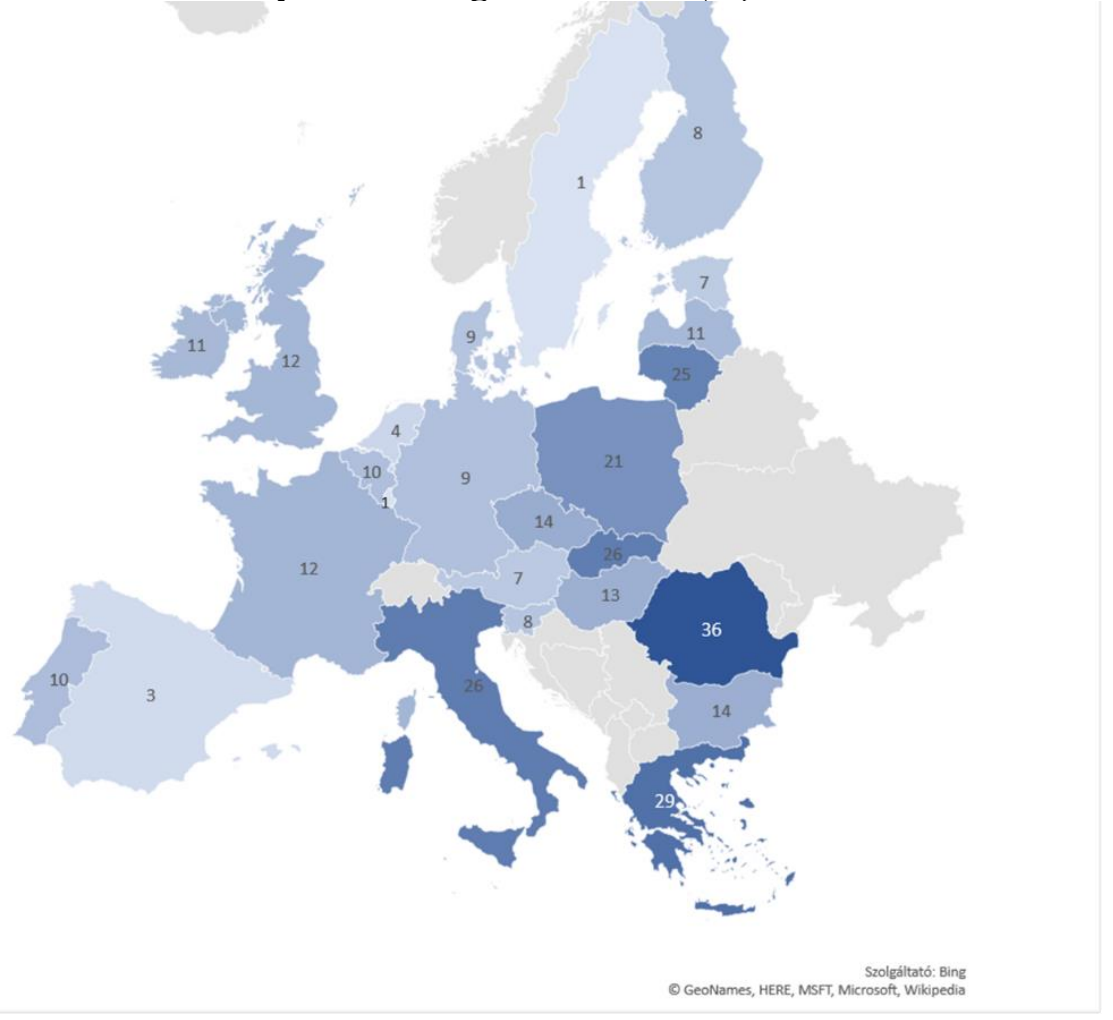


Az áfarést vizsgálva 2006-ban Magyarország a negyedik legmagasabb áfaréssel rendelkezett az EU tagállamok között (Romániát és Bulgáriát is beleértve). Az áfarést ekkor 23\%-ra becsülték, a legmagasabb áfarés Romániában volt, 37\%, a legalacsonyabb pedig Luxembourgban, 1\%. 2016-ra az áfarés jelentősen, 13\%-ra csökkent Magyarországon. Ugyanakkor a többi országban is hasonló volt az áfarés alakulása, de még így is javított az ország a relatív helyzetén, a kilencedik legmagasabb áfarést érte el Magyarország. A lista első és utolsó helyezettje változatlanul Románia (36\%) és Luxembourg (1\%). (Lásd: 15. ábra)

\subsection{Egyedi adatokra épülő modellek}

Az adminisztratív és egyéb egyedi adatforrások rendelkezésre állásával az egyedi adatokra épülő számítások jelentősége nő. Az egyedi szintű becslések felhasználásával az aggregálással fellépő információvesztés csökkenthető, ami egy olyan heterogén jelenség, mint az adócsalás esetében rendkívül fontos lehet.

\subsubsection{Szimulációs modell}

A rejtett gazdaságban való részvétel az egyén döntése, amelyet a körülmények kölcsönhatása is befolyásol. A gazdasági szereplő attitüdjei egymással összefüggő tényezők szerint alakulnak. Ebből a szempontból összetett, makromutatókat használó modellel nem becsülhetők. A rejtett gazdaság aránya és szerkezete nem tekinthető valamilyen konstans, külső adottságnak, de még egy viszonylag egyszerü függvényszerü kapcsolattal sem jellemezhető.

A szimuláció olyan mikroalapokon működő, indirekt módszer, amely a gazdaságpolitikai eszközök hatásait képes előre jelezni. Egyik típusa az ágens alapú modellezés, amely olyan számítógépen futó program, amiben egy szimulált társadalom müködik, tagjainak egyedi preferenciái vannak (létezhet a programban többek között tanulási folyamat, korlátozott információ, társadalmi kapcsolatok, intézmények, egyének és szervezetek életciklusa). Így a résztvevők döntéseinek kölcsönhatásai, az egyedi döntések hatása elemezhető az aggregátumokra. A módszer jól használható olyan területeken, ahol az adatgyüjtés nem lehetséges, vagy nagyon bonyolult és költséges. Ebben rejlik a módszer problémája is, hiszen az ágensek cselekvési szabályait, értékfüggvényét, vagyis a magatartásukat a szimuláció tervezői kódolják a rendszerbe. A magyar gazdaság 
müködésére felállított szimulációs modell eredményei szerint a kormányzat szolgáltatásainak minőségi javulása csökkenti a rejtett tevékenységeket.

A fehéredés ugyanakkor függ a versenyhelyzettől is. A vállalatok elszigetelten fellépő kezdeményezése az adócsaló magatartás megszüntetésére nem vezet eredményre ágazati, makrogazdasági szinten. Egy vállalat teljes „kifehéredése” a versenyhelyzetét annyira ronthatja, hogy akár a piacról is kiszorulhat. Végül fontos eredmény, hogy a globális gazdaságba való integrációnak kettős hatása van. A piacra újonnan belépő vállalatok adókedvezményeket kapnak, mely nekik jelentős versenyelőnyt, ami az ugyanazon piacon müködő versenytársaknak hátrányt okoz. Ezért az új, multinacionális cégek megjelenése a versenytársak számára növeli a rejtett gazdaságban való részvétel motivációját, míg a beszállítók számára ösztönzés a legális tevékenységre (Szabó, Gulyás, \& Tóth, 2009)

\subsubsection{Ellenőrzés adatok felhasználása}

Az Eurostat ajánlása alapján az adó és egyéb ellenőrzés adatok felhasználhatóságát az Európai Unió statisztikai hivatalainak meg kell vizsgálni a nem megfigyelt gazdaság becsléséhez a 98/527/EC bizottsági rendelet értelmében. Továbbá az Eurostat kifejezetten ajánlja az ellenőrzés adatok felhasználását az adócsalás miatt nem megfigyelt hozzáadott érték (N6) becsléséhez. (Lásd 2. táblázat)

Mivel az adóellenőrzés alanyai általában szisztematikus kiválasztással kerülnek az ellenőrzési folyamatba, ahol az adóhatóság célja azoknak a szervezeteknek az azonosítása, amelyek jelentős kockázatot jelentenek, valószínűleg adócsalók, ezért az ellenőrzött szervezetek állománya nem tekinthető mintának statisztikai értelemben. Mindazonáltal ezeknek az adatoknak a felhasználása sok lehetőséget rejt magában, hiszen ezek a nem megfigyelt gazdaságra vonatkozó adminisztratív adatforrások.

A jogszabályi elöírások ellenére az Európai Unió tagországai közül csak Németország, Franciaország, Finnország, Svédország, Málta, Luxemburg és Magyarország használ fel a fiskális vagy munkaügyi ellenőrzés eredményeket az N6 nem megfigyelt gazdaság kategória becsléséhez. Németország a munkaügyi ellenőrzések eredményét hasznosítja. (Statistische Bundesamt, 2016) Svédország a jövedelemadó ellenőrzések eredményét alkalmazza, Magyarország esetében az áfa ellenőrzés eredményekre épül a becslés. (Statistics Sweden, 2016) (Ritzlné Kazimir, 2014) A többi ország esetében adóellenőrzés 
eredményekre hivatkoznak a GNI Inventory publikációk. (INSEE, 2016) (Statistics Finland, 2016) (National Statistics Office - Malta, 2015) (STATEC, 2016)

Bár az Eurostat javasolja az ellenőrzés adatok felhasználását, azonban a módszertanhoz nem ad javaslatot. A tagországok beszámolói meglehetősen szükszavúak az alkalmazott módszertanok vonatkozásában. Kizárólag a francia GNI Inventory ${ }^{12}$ ad leírást arról, hogy a nem reprezentatív minta tulajdonságait milyen módszerrel küszöbölik ki. Első lépésben becsülik az ellenőrzésre való kiválasztás valószínüségét a következő változók alapján:

- $\quad$ szervezet jogi formája

- ágazat

- méret

- hozzáadott érték arány

- árrés arány.

A második lépésben a lehető leghomogénebb rétegeket hozzák létre a becsült valószínüségek alapján. A harmadik lépésben a homogén rétegben lévő ellenőrzött vállalkozásokra kiszámítják az eltitkolt adó arányát a hozzáadott értékhez, és ezt az arányt alkalmazzák a réteg minden vállalkozására.

A számítást a 2010-es vonatkozási évre végezték el úgy, hogy a 2004-2006 közötti ellenőrzések eredményeit használták fel a 2000-2006-os adóévekre vonatkozóan. A francia GNI Inventory is felhívja a figyelmet arra, hogy a becslés pontatlan számításokra vezethet, amennyiben nem minden tényezőt tudnak mérni, vagy beazonosítani, amelyek az adócsalást befolyásolják. (INSEE, 2016, old.: 281-283) Mivel az arányokat csak egy évre határozták meg, előfordulhat, az adócsalás változását a módszertan nem tudja követni és ez is pontatlan becslést eredményezhet.

$\mathrm{Az}$ ellenőrzés adatok adóparadicsomokban befektetett jövedelmek mikroadataival kombinálva becsülhető a legmagasabb jövedelmü rétegek adócsalása is. Kifejezetten gazdag országok esetében (Norvégia, Svédország) az adócsalás általános szintje alacsony, 3\% körüli. Azonban a jövedelem felső 0,1\%-át realizáló réteg jövedelmének 30\%-át titkolja el. A vizsgálat alátámasztotta, hogy az adócsalás növeli az

\footnotetext{
${ }^{12}$ A GNI Inventory olyan dokumentum, amely egy meghatározott referencia évre tartalmazza a GNI és GDP számítás összes adatforrását és a számítások részletes módszertanát. A dokumentum összeállítása az Európai Unió statisztikai hivatalai számára kötelező. Ez a dokumentum az alapja a számítások ellenőrzésének.
} 
egyenlőtlenséget, és felhívja a figyelmet arra, hogy az adminisztratív adatok alapján számított egyenlőtlenség a valóságosnál valószínűleg kedvezőbb képet mutat. (Alstadsæter, Johannesen, \& Zucman, 2017)

Tedds modellje szintén ellenőrzés adatokra épül. Bizonyította, hogy az értékesítések aluljelentését magyarázza a vállalkozás jogi formája, a méret, a vállalkozás kora, a tulajdoni viszonyai, a versenyhelyzet és az ellenőrzési valószínüség. Ugyanakkor szervezett bünözés, korrupció és politikai instabilitás nem befolyásolja az értékesítés aluljelentését. (Tedds, 2007) Tabandeh és Jusoh neurális hálók módszerével készülö becslése a jövedelmet és az normák negatív, a kormányzat mérete és az infláció nagysága pozitív hatással volt az adócsalásra. (Tabandeh \& Jusoh, 2012)

Egyedi adatokra épül Észtország kockázatbecslő modellje is. Az online számlák rendelkezésre állásával elméletileg lehetséges az output aluljelentése a költségek túljelentésének elkerülése is. Azonban az online számlák felhasználása technikai és jogi problémákat is felvet. Erre dolgoztak ki egy biztonságos többoldalú csalás detektáló rendszert, amely a bizalmas adatokat tekintetbe véve, a futási időt optimalizálva dolgozza fel a havi körülbelül ötven millió számlát. A becsléshez az értékesítéseket és beszerzéseket vetik össze páronként, és így detektálják a csalásokat. (Bogdanov, Jõemets, Siim, \& Vaht, 2015)

Az ellenőrzés adatok felhasználhatósága problémás, ha az adott gazdaságban a tranzakciók nagy hányada félig vagy teljesen informális és készpénzre épül a csere. Az ilyen gazdaságokban a jövedelmek jó része nem látható az adóhatóság számára. A bankok általában a bevallott jövedelmek alapján állapítják meg a hitelkeretet, ez azonban az ilyen kevésbé formális gazdaságokban a hitelkihelyezés elégtelen szintjét eredményezné. Ezért a bankok saját gyakorlatot vezettek be számos hasonló országban, és saját becsléssel állapítják meg a hitelképességet. Ezért fordulhat elö, hogy a hitel törlesztőrészlete a bevallott jövedelem 100\%-át is elérheti.

Artavanis és szerzőtársai alkalmazottak és egyéni vállalkozók egyedi hiteladatai alapján becsülték az egyéni vállalkozók eltitkolt jövedelmét Görögországban. Eredményük szerint 1,75-1,84 szerese a valós jövedelem a bevallottnak. Legnagyobb a jövedelem eltitkolás aránya a magas iskolázottságot igénylö, informális üzleti kapcsolatokra épülő ágazatok esetében. Ilyen az üzleti szolgáltatások, oktatás és egészségügy. (Artavansi, Morse, \& Tsoutsoura, 2015) 


\section{4. Összefoglaló}

$\mathrm{Az}$ adócsalás becsléséhez alapvetően háromféle becslési megközelítés állhat rendelkezésre. Az aggregátumokat ökonometriai módszerekkel becsülő módszerek gyors, egyszerü és viszonylag alacsony adatigényességü eljárások. Eredményeik a jelenségek alakulására jó támpontot adhatnak, miközben megvilágíthatják a közgazdasági összefüggéseket. Részletes eredmények előállítására nem alkalmasak, és bizonyos esetekben a mutatók tartalma nem elég alaposan lehatárolt.

Az input-output struktúrákon alapuló becslésekhez szükséges olyan adat, amely megbízhatónak tekinthető, amely tartalmazza az összes, csalással érintett tevékenységet. Ekkor a különbségek, arányok elemzése támpontot adhat a hiányzó értékek becsléséhez. A becslésekhez számos szigorú feltételt szükséges. Ezekből a számításokból a legkomplexebb rendszer az áfarés számítás, amely feltételezi, hogy a felhasználási tételekre jutó áfa meghatározható.

Az egyedi adatokra épülő számítások az adminisztratív adatforrások rendelkezésre állásával vállnak egyre inkább relevánssá. Az adócsalás annyira sokrétü, hogy az egyedi adatok használatával a megfelelő információk és mintázatok jobban felderíthetők és hasznosíthatók. Bár az adóellenőrzések eredménye statisztikai szempontból problémás, azonban mégis több országban is müködő gyakorlat a fiskális csalás becslése ellenőrzés adatok felhasználásával.

\section{Az áfacsalás számszerúsítése, az eredmények elemzése}

Az áfacsalás számszerüsítésének lépéseihez az első szükséges lépés az input adatbázisok összeállítása. Az adatok vizsgálata, a szükséges tesztek elvégzése majd a becslés következett. Végül a területi és idősoros adatok elemzésére alkalmas panel modell illesztése következett. A fejezetben prezentált modell és az áfacsalás számszerüsítésének ismertetése nagymértékben támaszkodik Ritzlné Kazimir Ildikó és Máténé Bella Klaudia által publikált tanulmány. (Ritzlné Kazimir \& Máténé Bella, 2020) 


\subsection{Alapadatbázis összeállítása}

Az alapadatbázisok összeállítása során elsőként megvizsgáltam, hogy milyen lehetséges input adatforrások állnak rendelkezésre. Ezekhez a KSH-ban rendelkezésre álló adatbázisokat tekintettem át. Ezután az adatokat egyedi szinten összefüztem egy egyesített adatbázisba. Végül a rendelkezésre álló mutatókból további arány és kategória jellegű mutatókat képeztem.

\subsubsection{Input adatok}

A vizsgált időszakra, a 2006-2016 évek mindegyikére összeállítottam egy vállalkozás szintű adatbázist a következő adatforrások felhasználásával:

- adóellenőrzés adatbázis az adóellenőrzés tényével és eredményével

- $\quad$ KSH Gazdasági Szervezetek Regisztere (GSZR)

- Éves gazdaságstatisztikai adatgyüjtésből származó adatok és a társasági adóbevallás adatbázis

- áfa adóbevallás adatbázis

Az adatokat egyedi, gazdasági szervezet szinten füztem össze. Az összefüzés alapja a statisztikai számjel, amelynek első nyolc számjegye a törzsszám. Ez a szervezet egyedi azonosítója, amelyet a KSH adatbázisai tartalmaznak.

Az adóellenőrzés adatbázis esetében az éves gyakoriságú adatállomány 2011-től kezdve áll rendelkezésre, és az áfa ellenőrzések jogerős eredményeit tartalmazza az átadást megelőző 5 évre. Így a 2011-es vonatkozási évtől kezdve minden évre 5 adatátadás áll rendelkezésünkre. Az adóellenőrzések az állapotévet megelőző 5 évre terjednek ki, és egyszerre több év is ellenőrzésre kerülhet. Egy évet általában csak egyszer ellenőriz az adóhatóság, ugyanakkor a megállapítás csak a rendelkezésre álló fellebbezési időszakok leteltével válik jogerőssé. Így bizonyos esetekben akár néhány év is eltelhet az ellenőrzés és a jogerőssé válás között. A jogerős megállapítások, vagyis az ellenőrzött vállalkozások halmaza bővül egy adott adózási évre az újabb adatátadásokkal, hiszen az idő elteltével egyre több megállapítás válik jogerőssé.

A KSH Gazdasági Szervezetek Regisztere minden olyan gazdasági egységet tartalmaz, amely adószámmal rendelkezik Magyarországon. A GSZR adatbázis hetente frissül, a szervezetek jellemzőit tartalmazza. Ilyenek többek között például az alapításra, átalakulásra és megszünésre vonatkozó dátumok, a tevékenységre vonatkozó információk 
és dátumok: székhely, gazdálkodási forma, gazdasági tevékenység. A GSZR az alapja a mintavételi eljárásoknak, az adatgyüjtési és feldolgozási folyamatoknak a KSH-ban.

A GSZR táblarendszere ORACLE adatbázis rendszerben 1998 óta áll rendelkezésre. (KSH, 2011)

A GSZR mindig a legfrissebb állapotot tartalmazza, azonban a szervezetek teljes története feltérképezhető a segítségével. A jelen vizsgálat szempontjából az adott vonatkozási évekre az adott év utolsó napján érvényes állapot szerint kimentett éves GSZR táblákat használtam fel.

Az Éves gazdaságstatisztikai adatgyüjtésből származó adatok és a gazdálkodó szervezetek adóbevallásainak (társasági adóbevallás, EVA, KATA és KIVA bevallások, ill. az egyéni vállalkozások személyi jövedelemadó bevallása, továbbiakban leegyszerüsítve társasági adó) adatbázisa egy olyan egyesített, ORACLE adatbázis, amely egyik legfontosabb célja, hogy a Nemzeti számlák éves számításaihoz nyújtson alapadatokat a nem pénzügyi vállalatokra és az egyéni vállalkozókra vonatkozóan. Az adatbázis az adatok megfelelő kereszt-ellenőrzés után kerülnek be, és belső koherenciájuk egyedi szinten biztosított. (KSH, 2011)

Az Éves gazdaságstatisztikai jelentés a 2239-es, a 2157-es kérdőív a szakosodott egységekről és a 1845-ös számú OSAP (Országos Statisztikai Adatgyüjtési Program) elemeket tartalmazza. Az adatfelvételt és annak keretrendszerét Európai Uniós jogszabályok sokasága írja elő és szabályozza. Ezeknek megfelelően Magyarországon a 388/2017 (XII. 13.) Kormányrendelet az Országos Statisztikai Adatfelvételi Program kötelező adatszolgáltatásairól jogszabály alapján a kérdőív a következő mutatócsoportokat tartalmazza:

(1) Munkaügyi adatok (éves átlagos létszám, éves munkajövedelem, teljes és nem teljes munkaidőben foglalkoztatottak által teljesített munkaórák száma)

(2) Értékesítés nettó árbevétele

(3) Tárgyi eszközök eladásából származó bevétel

(4) Anyag- és energiaköltség

(5) Eladott áruk beszerzési értéke

(6) Közvetített (eladott) szolgáltatások értéke 


\section{(7) Egyéb költségek}

(8) Beruházási adatok (Épületek és egyéb építmények, Belföldi és import gépek, berendezések, Belföldi és import gyártású járművek, Ültetvények, erdők, tenyész- és igásállatok, föld telek és más nem termelt tárgyi eszközök beruházási értéke). (KSH(a), 2020)

A kérdőív a legalább 20 főt foglalkoztató vállalkozások körében teljes körü, a legfeljebb 19 főt foglalkoztatók esetében mintavételes megkérdezésen alapul. Az adatfelvétel 2013tól kétféle kérdőívet tartalmaz. A legfeljebb 4 főt foglalkoztató vállalkozások egy egyszerüsített kérdöívet (1845-ös számú OSAP) töltenek ki. A 4 főnél többet foglalkoztató vállalkozások számára kerül kiküldésre a 2239 és a 2157-es számú kérdőív. (KSH(a), 2020)

A társasági adó adatokat a teljesítménystatisztika kiegészítésére, ellenőrzésére, pótlásra, teljeskörüsitésre ${ }^{13}$ és becslésre is felhasználják. (KSH(a), 2020) A társasági adó adatok az eredménykimutatás bizonyos tételeit tartalmazzák. Az adatok részletezettsége függ az adónemtől és a könyvvezetés módjától. Ezen kívül a társasági adó adatok közül ki kell még emelni a személyi kifizetésekre vonatkozó és a munkaügyi kiegészítő adatokat, amelyek az eredménykimutatás adatokhoz hasonló szerepet töltenek be. (KSH, 2011)

Az áfa adatbázis az áfa bevallások legfontosabb mutatóit tartalmazza. Az áfa bevallás elemei elsősorban a forgalomra és nem a teljesítményre vonatkoznak. Emiatt érdemes mindkét adatkört egyaránt vizsgálni. Az áfa bevallás rendkívül részletes, a kutatás szempontjából fontos részei a beszerzésre (közösségen belüli és közösségen kívüli beszerzés, ill. belföldi beszerzés), értékesítésre (export és belföldi értékesítés), a fizetendő és az előzetes áfa alapjára, ill. az adóra vonatkozó adatok.

Az áfa bevallás gyakorisága havi, negyedéves és éves lehet, az adatbázis összeállításához az adatokat éves gyakoriságúra aggregáltam.

A gazdasági szervezetek közül az áfa alany nem pénzügyi vállalatokra és egyéni vállalkozókra készítettem el a becslést. A sokaság lehatárolásának alapja az, hogy a nemzeti számlák összeállítása során öt intézményi szektort különítenek el: 1. nem pénzügyi vállalatok; 2. pénzügyi vállalatok; 3. kormányzat; 4. háztartás; 5 . háztartásokat segítő nonprofit szervezetek. Az áfacsalás ezek közül a nem pénzügyi vállalati szektorban

\footnotetext{
${ }^{13}$ A teljeskörüsítés felszorzáson alapuló átlagbecslés a standard hiba meghatározásával.
} 
és a háztartás szektorban lehet jellemző. (A többi szektorban vagy nem végeznek piaci termelést, vagy tevékenységük miatt áfa mentesek a gazdasági szereplők.) A háztartás szektorban azonban több tevékenység is számításba van véve, ezek közül a kutatás vonatkozásában az egyéni vállalkozók termelése releváns. (KSH, 2011)

Az intézményi szektorok elkülönítésének elsősorban a gazdálkodási forma és a tevékenység az alapja. A gazdálkodási forma (GFO) a 21/2012. (IV. 16.) KIM rendelet a statisztikai számjel elemeiről és nómenklatúráiról jogszabállyal van meghatározva, a statisztikai számjel 13-15 szemjegyével azonos. A GFO a gazdálkodási formákat azonosítja, amelyek törvényekben vagy más magas szintü jogszabályokban vannak nevesítve. A GFO-t a GSZR tartalmazza, ez a gyakorlatban egy háromszintü nómenklatúra. (KSH(b), 2020) A nem pénzügyi vállalkozások a jogi személyiségü vállalkozások, amelyeknek a GFO kódjuk 1-gyel kezdődik. Az egyéni vállalkozók pedig a 231-es GFO kóddal rendelkeznek. A kód első számjegye (2) a jogi személyiség nélküli vállalkozásokat jelenti, ezen belül a 23 az önálló vállalkozók kódja.

A nem pénzügyi vállalkozások halmazának meghatározásához szükség van tevékenység szerinti szürésre is, a TEÁOR kód alapján. A nómenklatúra bevezetésének jogi alapja az Európai Parlament és a Tanács 1893/2006/EK rendelete (2006. december 20.) a gazdasági tevékenységek statisztikai osztályozása NACE Rev.2 rendszerének létrehozásáról.

A TEÁOR egy olyan négyszintű nómenklatúra, amelynek az első szintje a nemzetgazdasági ágat (betủvel jelölve A-tól U-ig), a második szint az ágazatot, a harmadik szint az alágazatot, a negyedik szint a szakágazatot jelöli. A TEÁOR'08 nómenklatúra 2008. január 1-jétől került bevezetésre, elődje a TEÁOR'03 osztályozás volt. A két osztályozás 2011. december 31-ig párhuzamosan volt érvényben, figyelembe véve például a nemzeti számla számítások adatigényeit. Az elemzésből kizártam azokat a jogi személyiségű vállalkozásokat, amelyek a K, Pénzügyi és biztosítási tevékenység nemzetgazdasági ágban tevékenykednek. (KSH(c), 2020)

A többi intézményi szektorba tartozó gazdasági szervezetekre (pénzügyi vállalatok, kormányzat, háztartásokat segítő nonprofit szervezetek) nem végeztem áfacsalás becslést, feltételeztem, hogy körükben az áfacsalás nem jellemző. Az elemzésbe bevont szervezetek ágazatok szerinti megoszlását a következő ábra mutatja be. 
16. ábra: Az elemzésbe bevont vállalkozások számának alakulása és megoszlása nemzetgazdasági ágak szerint (db)

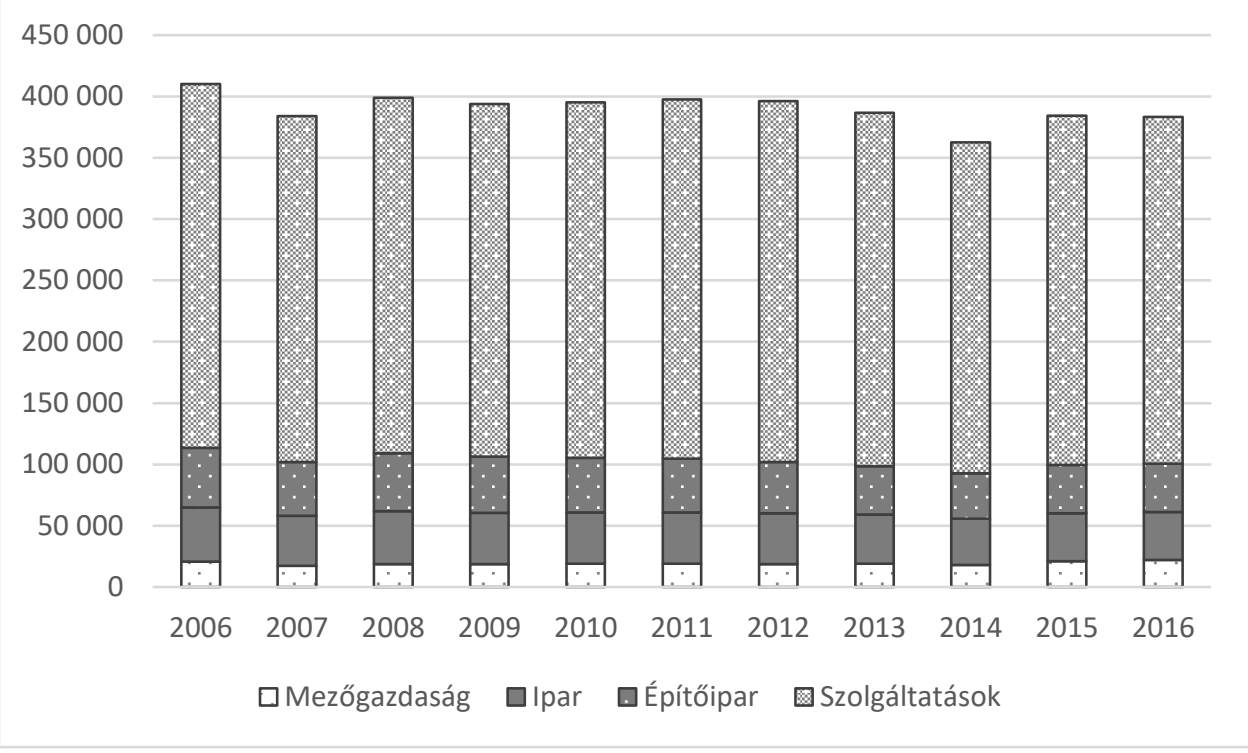

Forrás: saját szerkesztés

A vizsgálatba bevont szervezetek száma a vizsgált időszakban 350-400 ezer db körül alakult. A 16. ábra alapján jól látható, hogy az elemzésbe bevont szervezet közül a legtöbb a szolgáltatások nemzetgazdasági ágban müködik, arányuk átlagosan $76 \%$ a vizsgált időszakban.

\subsubsection{Mutatók kiszámítása}

A TEÁOR'08 nómenklatúra a 2006, 2007. évek adataira nem állt rendelkezésre, ezekben az években a nómenklatúra előző TEÁOR'03-as változata volt használatban. A két nómenklatúra közti megfeleltetés nem egyértelmü.

$\mathrm{Az}$ alapadatok és a végeredmények összehasonlíthatósága érdekében az aggregált adatokat a 2006. és a 2007. évre átfordítottam a TEÁOR'03-as nómenklatúráról a TEÁOR'08 besorolásra. Az átfordításhoz szükséges fordítókulcsokat a 2008-as évre határoztam meg, arra az évre mindkét nómenklatúra egyszerre állt rendelkezésre. A fordítókulcs egy mátrix az alábbiak szerint:

$A=\left[\begin{array}{cccc}x_{12} & x_{21} & \ldots & x_{m 1} \\ x_{21} & x_{22} & \ldots & x_{m 2} \\ \vdots & \vdots & \ddots & \vdots \\ x_{n 1} & x_{n 2} & \ldots & x_{m n}\end{array}\right]$ 
Az $n$ a TEÁOR'08 nómenklatúra szerinti besorolásokat jelenti, az $m$ pedig a TEÁOR'03as besorolás szerinti megoszlást mutatja meg. Az $x_{i j}$ elem az átfordításhoz használt proxy aránya 2008-ban a TEÁOR'08 szerinti $i$ tevékenység szerinti összesen a TEÁOR'03-as $j$ tevékenység szerint, vagyis:

$\sum_{j=1}^{m} x_{i j}=1, \quad i=1, \ldots, n$.

Az átfordítást a következő művelettel végeztem el:

$A\left[\begin{array}{c}y_{1} \\ \vdots \\ y_{m}\end{array}\right]=\left[\begin{array}{c}z_{1} \\ \vdots \\ z_{n}\end{array}\right]$

Ahol $(y)$ a TEÁOR'03 szerint rendelkezésre álló adat vektor, $(z)$ pedig az a TEÁOR'08 nómenklatúrára átfordított vektort jelenti.

A szervezetek darabszámának átfordításához a szervezetek számát tartalmazó mátrixot használtam, az áfa és az áfacsalás adatok átfordításához a bruttó hozzáadott értékre felírt mátrixot alkalmaztam.

Az adóellenőrzés adatbázis sajátossága, hogy a megállapított adókülönbözet a teljes ellenőrzött periódusra, akár több adóévre egy összegben áll rendelkezésre, emiatt ennek felosztása szükséges. Több év esetében az adóellenőrzés megállapítását az egyes években az adott vállalat által megtermelt hozzáadott érték arányában osztottam fel, feltételezve a hozzáadott értékkel arányos adócsalást.

VATfraud $_{i t}=$ VATfraud $_{i y} \frac{g v a_{i t}}{g v a_{i y}}$

ahol a $V A T$ fraud $_{i t}$ az ellenörzött $i$ gazdasági szereplő becsült be nem fizetett áfa értéke (áfacsalás) a $t$ évre. A VAT fraud $i y$ az egy ellenőrzés során megállapított be nem fizetett áfát jelenti az $i$ gazdasági szereplöre. Az y azoknak az éveknek a halmaza, elemszáma legfeljebb öt, amelyeket az adóhatóság az $i$ gazdasági szereplőre egy ellenőrzés során egyben megvizsgált, $t \in y$. A $g v a_{i t}$ az $i$ gazdasági szereplő $t$ évre kiszámított bruttó hozzáadott értékét jelenti, és $g v a_{i y}=\sum_{j \in y} g v a_{i j}$.

A 17. ábra az ellenőrzött és áfacsaló vállalkozások alakulását mutatja meg: 


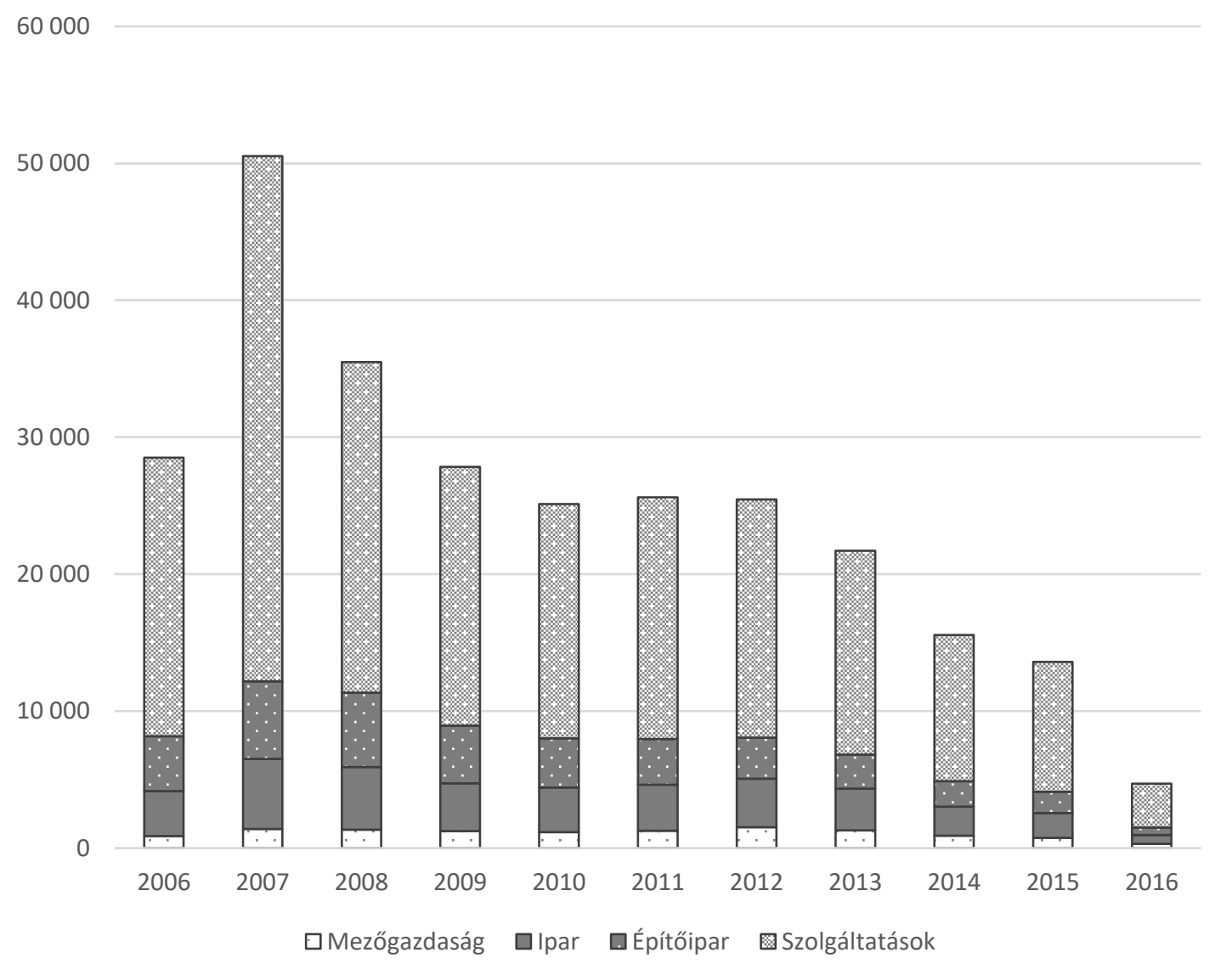

Forrás: saját szerkesztés

A 17. ábra alapján látható, hogy az adóhatóság új ellenőrzési stratégiát vezetett be 2007 után. Ahogy korábbiakban a gazdasági és szabályozási környezet ismertetésekor bemutattam (lásd 2.3.2.3 alfejezet), az adóhatóság fokozatosan átállt a szolgáltató adóhatóság koncepcióra, arra törekedett, hogy az adózók számára a lehető legtöbb segítséget nyújtsa ahhoz, hogy azok magatartása jogkövető legyen, és az ellenőrzéseket szintén fokozatosan a jelentős költségvetési kockázatot jelentő adócsaló tevékenységek felderítésére állítsák át. A magatartás változását a NAV ellenőrzési irányelveiben meghirdetett stratégia támasztja alá.

Az ellenőrzöttek közül az áfacsaló vállalkozások alakulását a 18. ábra mutatja be. 
18. ábra: Az ellenőrzések során áfacsalónak bizonyult vállalkozások számának alakulása és megoszlása nemzetgazdasági ágak szerint (db)

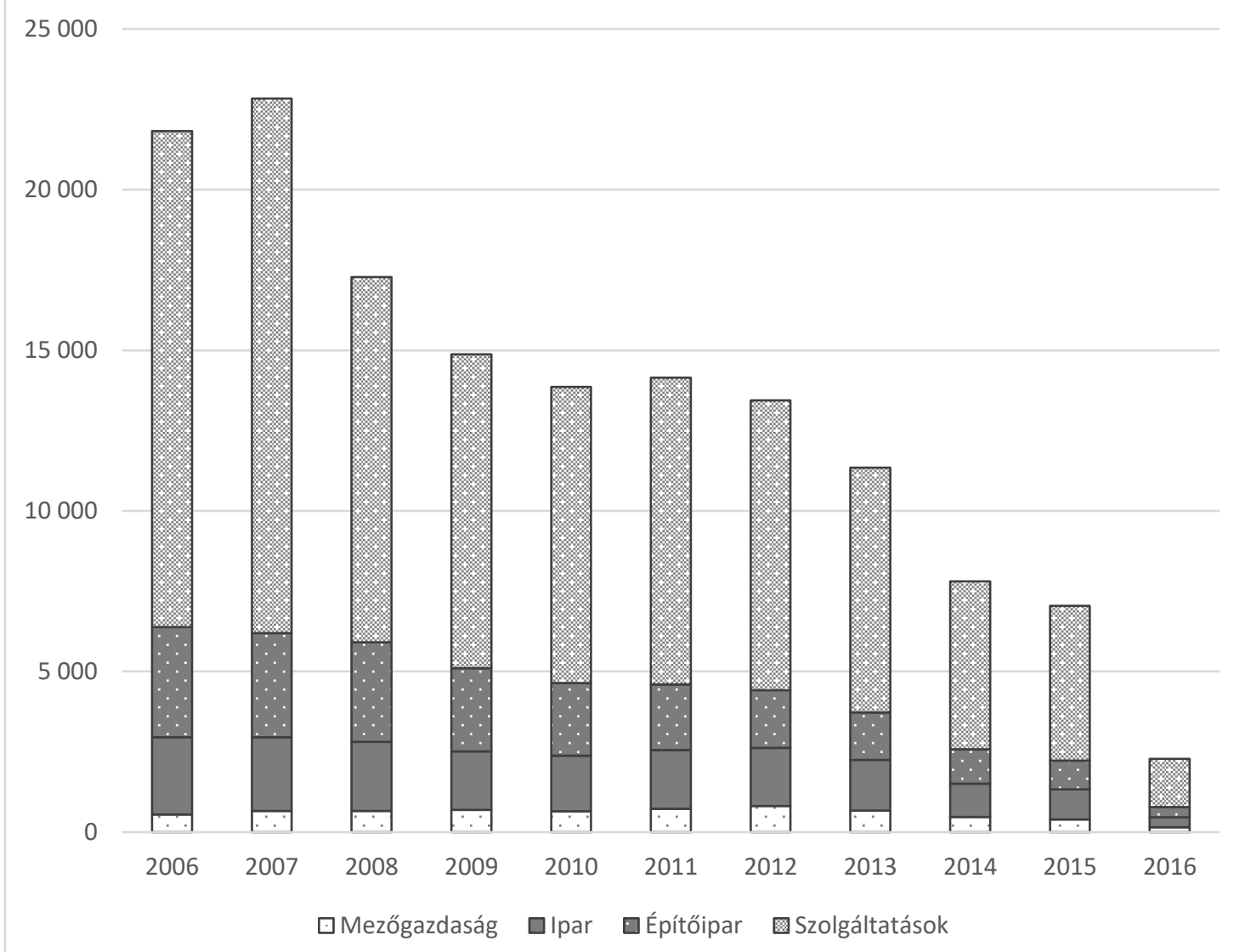

Forrás: saját szerkesztés

Az összes szervezet, az ellenőrzöttek és az áfacsalónak bizonyuló szervezetek nemzetgazdasági ágak szerinti megoszlása rendkívül hasonló. Az ellenőrzöttek és az áfacsalók között az építőipari tevékenységet végzők kis mértékben felülreprezentáltak.

A kiválasztott szervezetek arányát az összes vizsgálatba bevont szervezethez viszonyítva az alábbi ábra tartalmazza. 
19. ábra: Az ellenőrzésre kiválasztott szervezetek aránya az egyes adózási évekre

\section{nemzetgazdasági áganként, \%}

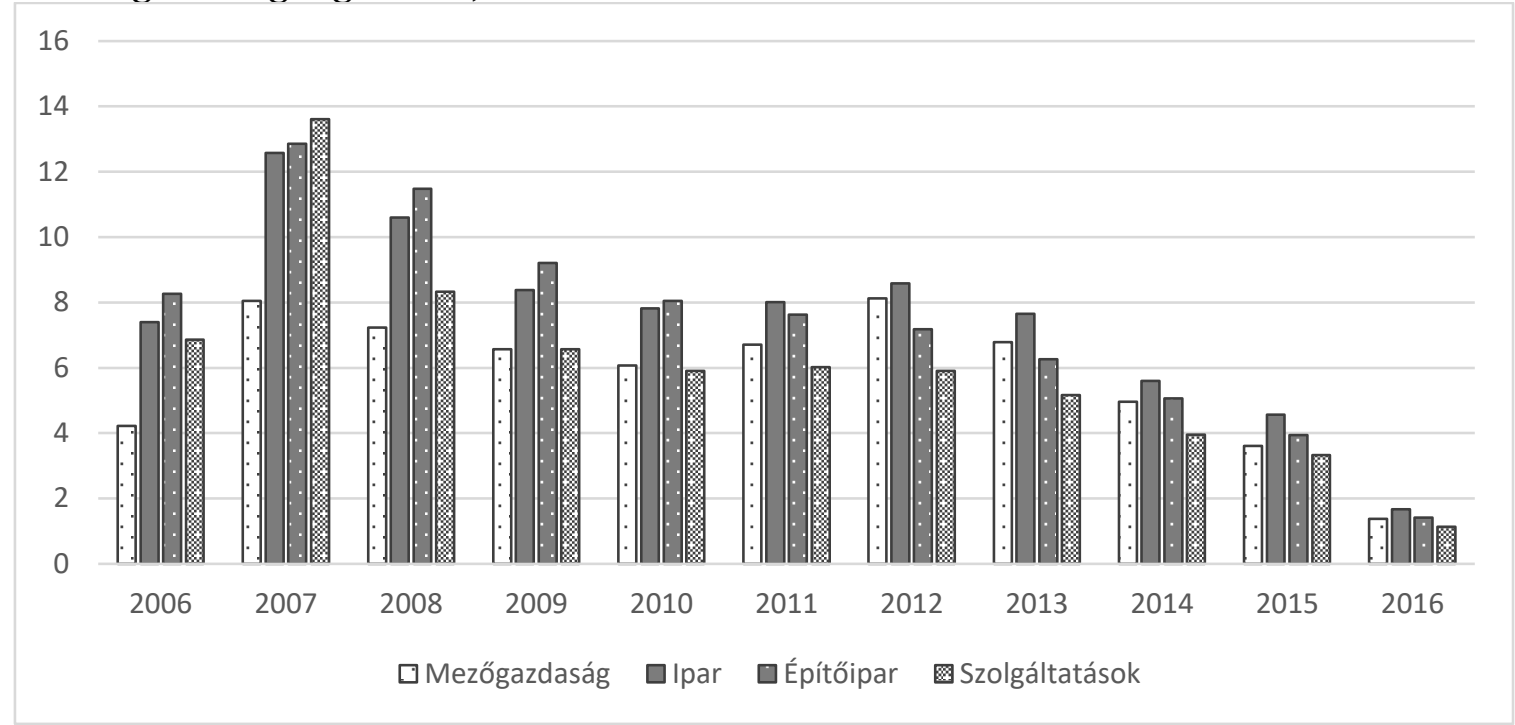

Forrás: saját szerkesztés

A 19. ábra alapján látható, hogy a 2007-es évet ellenőrizték a legnagyobb arányban a vizsgált időszakban. Az építőipari vállalkozások aránya az ellenőrzések során egészen 2011-ig magas annak ellenére, hogy a fordított áfát egyes építőipari tevékenységekre már 2008-ban bevezették, és 2014-ben kiterjesztették.

A mezőgazdaságban a fordított áfát 2012. január 1-jétől vezették be a gabona és olajos magvak termékekre vonatkozóan. A bevezetés oka az volt, hogy ezekkel a termékekkel a hálózatos áfacsalások rendkívül gyakorivá váltak. A csalás során minimális törzstőkéjű vállalkozások importáltak gabonaféléket, amelyeket továbbértékesítettek, az áfafizetési kötelezettségüket pedig fiktív számlák befogadásával tüntették el. A csalással érintett termék útja aztán már legálissá vált, a vásárló cégek nem firtatták azok eredetét. (Becker, 2017) 2011 után az iparban működő vállalkozások áfa ellenőrzésének relatív gyakorisága emelkedett, a jelenség összefügghet a NAV ellenőrzési stratégiájának változásával, vagyis, hogy a nagyobb kockázatot jelentő cégek ellenőrzésére fókuszálnak az ellenörzések során.

Az ellenőrzések eredményességének arányait nemzetgazdasági áganként a következő, 20. ábra tartalmazza. 


\section{0. ábra: Az áfacsaló vállalkozások ellenörzött szervezetekhez viszonyított aránya}

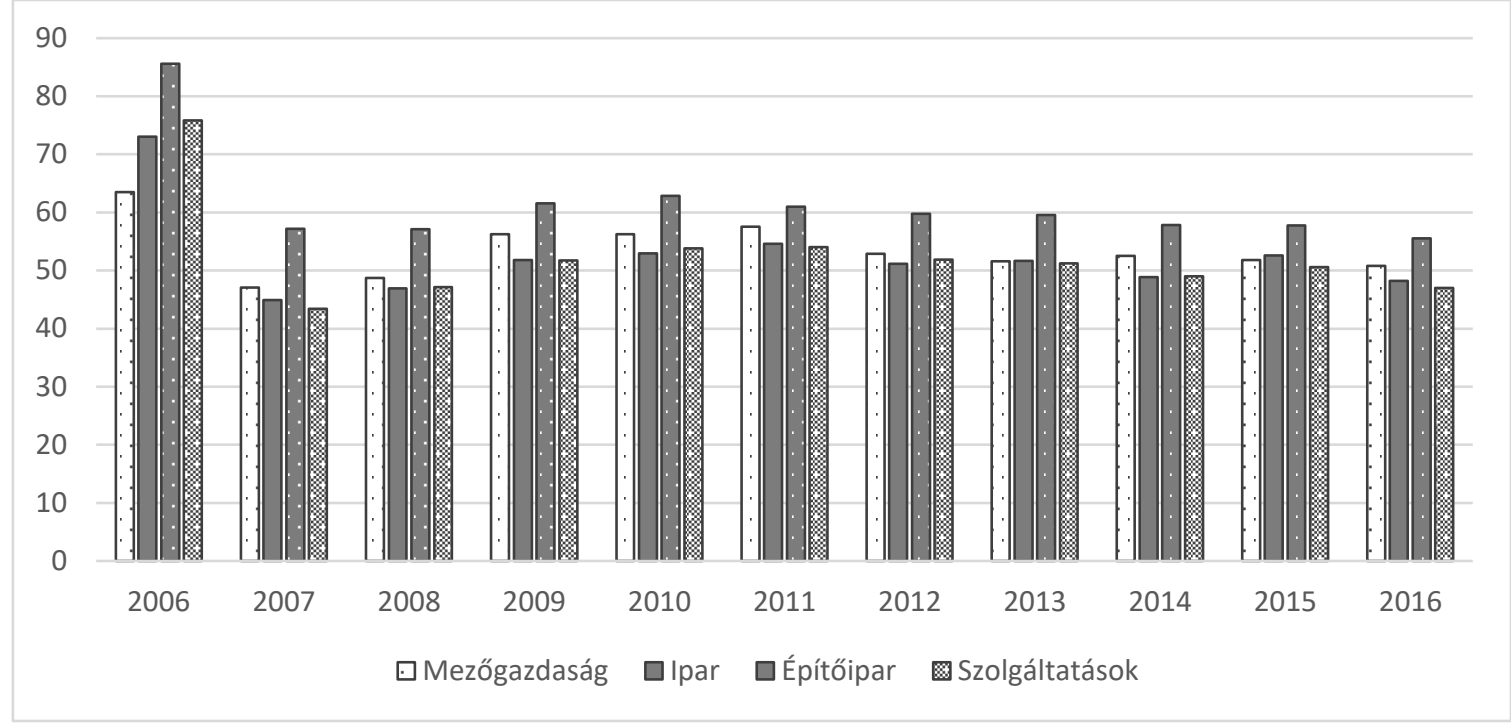

Forrás: saját szerkesztés

Az ellenőrzött vállalkozások közül minden évben az építőiparban volt a legmagasabb az áfacsaló vállalkozók aránya. A mezőgazdaságban 2009-2012 között volt magas az ellenőrzöttek között az áfacsalók aránya. Ez volt az az időszak, amikor a gabona és olajos magvakkal kapcsolatos csalások különösen elterjedtek voltak.

Az áfa ellenőrzések eredményessége az első adatállomány esetén 75\% volt (lásd a 2006. évet a 17. ábra 18. ábra alapján), a későbbi években azonban 45 és 55\% között alakult. Javuló tendencia nem figyelhető meg ebböl a szempontból.

A NAV ellenőrzési irányelveiben meghatározott tevékenységek, amelyek évenként eltérők lehetnek, mérsékelten érhetők tetten az ellenőrzések és az áfacsalók számában. Az adóhatóság stratégiája a teljes ellenőrzési tevékenységre van meghatározva, abból az egyes adónemek kiragadott vizsgálata csak egy szeletét mutatja a tevékenységnek.

Az áfa ellenőrzések felbontása után az éves gyakoriságú, összes szervezetet tartalmazó adatbázishoz hozzáfüztem az adott év ellenőrzési állományát, és kiegészítettem az éves gazdaságstatisztikai adatgyüjtésből származó és társasági adóbevallás adatbázis adataival, továbbá az áfa bevallások adatbázisának néhány mutatójával, majd ezekből számított mutatókat képeztem.

A Gazdasági Szervezetek Regisztere a vállalkozások működésére vonatkozó nominális változókat tartalmazza. Ezek közül felhasználtam a TEÁOR besorolást, ami a vállalkozás 
főtevékenysége szerinti ágazatot mutatja meg, a megye kódot, a gazdálkodási forma kódot, ami a vállalat működésének jogi formáját tartalmazza, illetve a szervezet alapításának az évét.

Az éves gazdaságstatisztikai adatgyüjtés és társasági adóbevallás adatokat tartalmazó adatbázisból a vállalkozások gazdasági teljesítményére vonatkozó adatokat használtam fel. Ezek voltaképpen a szervezetek éves beszámolójából származó eredménykimutatás adatok, amelyekből a következő módon számítható ki a kibocsátás és a folyó termelőfelhasználás:

+ Árbevétel

+ Aktivált saját teljesítmény értéke

- Eladott áruk beszerzési értéke

- Eladott közvetített szolgáltatások értéke

Kibocsátás

+ Anyagköltség

+ Igénybe vett szolgáltatás

+ Igénybe vett egyéb szolgáltatás

+ Egyéb szolgáltatások

Folyó termelöfelhasználás

A kibocsátás és a folyó termelőfelhasználás különbsége a bruttó hozzáadott érték:

$g v a_{i}=$ kibocsátás $_{i}-$ folyó termelőfelhasználás $s_{i}$

A bruttó hozzáadott értéket $\left(g v a_{i}\right)$ minden $i$ szervezetre egyedi szinten számoltam ki.

A számítás menete a hazai számviteli rendszerre alkalmazva a GNI Inventory of Hungary kiadványban található. (KSH, 2011, old.: 61)

Az előző mutatókon kívül az alkalmazottak statisztikai állományi létszámát, továbbá a személyi kifizetéseket használtam fel.

Az áfa adatbázisból éves szintre aggregálva kiszámítottam a belföldi beszerzés, import, összes beszerzés, belföldi értékesítés, export, összes értékesítés, ill. a tárgyidőszakra jutó áfa mutatókat.

Az összefüzött adatbázisban rendelkezésre álló mutatókból az alábbi mutatókat számítottam ki: 
- Anyagköltség aránya az igénybe vett szolgáltatások és egyéb szolgáltatások összegéhez

- Bruttó hozzáadott érték aránya a kibocsátáshoz

- Személyi kifizetések aránya a kibocsátáshoz

- Személyi kifizetések aránya a bruttó hozzáadott értékhez

- Anyagköltség aránya a bevételhez

- Közvetített szolgáltatások aránya az összes bevételhez

- Eladott áruk beszerzési értékének aránya az összes bevételhez

- Értékesítés aránya a beszerzéshez

- Értékesítés aránya a fizetendő áfa alapjához

- Beszerzés aránya az előzetesen felszámított áfa alapjához

- Tárgyidőszakra jutó áfa aránya a fizetendő áfa és előzetes áfa alapjának a különbségéhez

- Export aránya az értékesítéshez

- Import aránya a beszerzéshez

- Egy főre jutó bruttó hozzáadott érték

- Egy före jutó személyi kifizetés

Az arányokon kívül a következő kategória jellegü változókat is létrehoztam:

- Létszám kategória, ami a KSH által használt létszám kategóriával megegyezik

- Régió

- Nemzetgazdasági ág.

A következő létszámkategóriákat képeztem:

3. táblázat: Az alkalmazott létszámkategóriák

\begin{tabular}{|c|}
\hline Létszámkategóriák \\
\hline ם,a0- - \\
\hline 0.05- a, fó fó \\
\hline a10-019 fö \\
\hline a20- 049 fö \\
\hline o50-249 fö \\
\hline
\end{tabular}

Forrás: KSH alapján saját szerkesżés

A területi statisztikába általában a NUTS besorolási rendszert alkalmazzák. A NUTS osztályozás (Nomenclature of Territorial Units for Statistics, Statisztikai Célú Területi Egységek Nomenklatúrája) egy hierarchikus rendszer az EU és az Egyesült Királyság 
gazdasági területének felosztásához. A jelenleg érvényben lévő NUTS 2016 besorolás 2018. január 1-jétől érvényes. (A vonatkozó jogszabály az Európai Parlament és a Tanács 1059/2003/EK rendelete.) Ez a többszintű csoportosítás eltér a becslésben alkalmazottól. A NUTS1 szint az országrészeket jelöli, három része van Magyarországon, Dunántúl, Közép-Magyarország, Alföld és Észak. A NUTS2 szint nyolc részre osztja az országot, végül a NUTS3 a megyei besorolásokat takarja.

Az adócsalás vonatkozásában a NUTS besorolásoknak nem volt megfelelő magyarázó ereje. Az adócsalások megyei megoszlását vizsgálva, az adócsalók és a megye változók klaszter analízise alapján alakítottam ki a régiós besorolást, amely az alábbi 21 . ábrán lévő térképen látható.

\section{1. ábra: Az elemzéshez alkalmazott régiós besorolás}

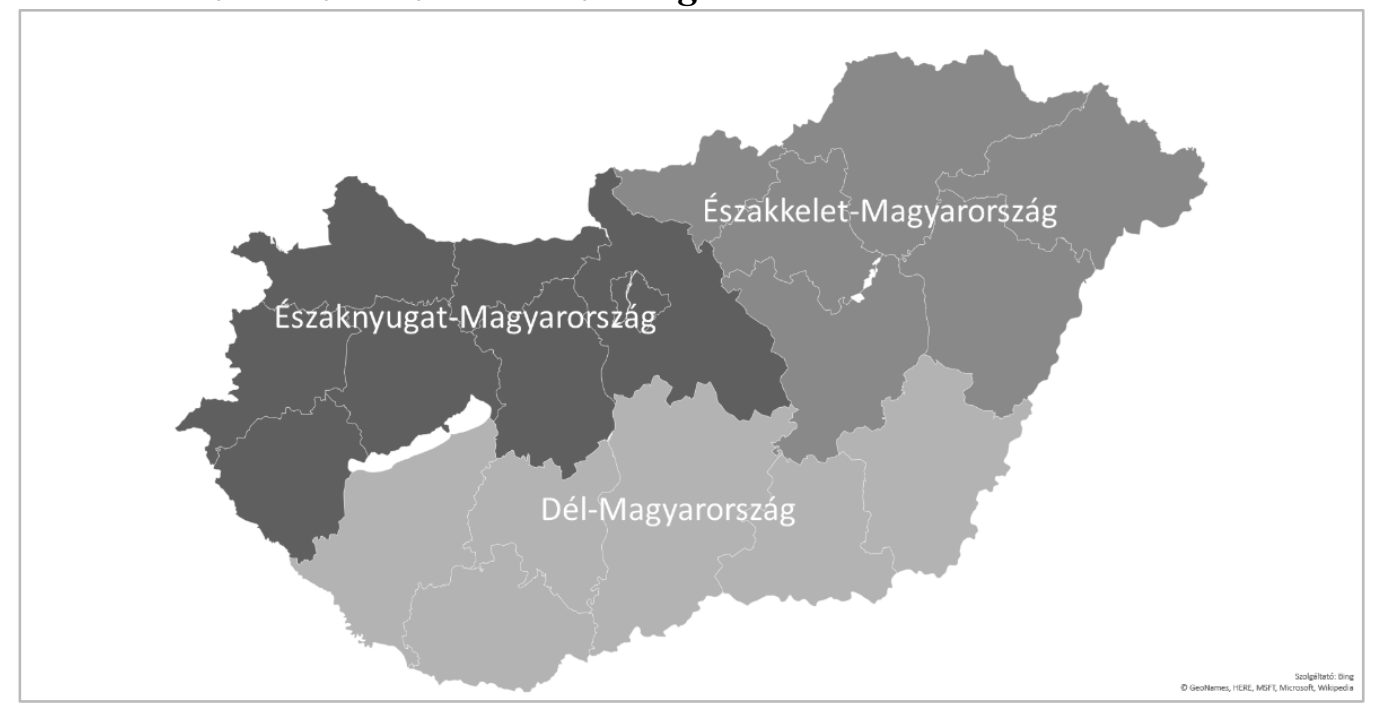

Forrás: saját szerkesztés

A 21. ábra alapján a modellben használt regionális besorolás szerint Dél-Magyarország, Északkelet Magyarország és Északnyugat Magyarország tartozik külön területi egységbe. A nemzetgazdasági ág változóra a következő csoportokat képeztem: Mezőgazdaság, Ipar, Építőipar, Kereskedelem, Szállítás, Egyéb szolgáltatások. A Szolgáltatások nemzetgazdasági ága gyüjtőkategória, amely a kereskedelem és a szállítási tevékenységeken kívül az összes többi szolgáltatásban tevékenykedő szervezetet tartalmazza.

Végül mindegyik szervezetre kiszámítottam a nettó árbevétel változó alapján az adott TEÁOR szerinti kétjegyü ágazatban realizált piaci részesedését. Mivel a vállalatok piaca 
nem tökéletesen lehatárolható, ezért a statisztikai fötevékenység szerinti azonos vállalatokat tekintettem egységes piacnak.

Az adatbázisokban kiszámított mutatók meghatározását nagyban elősegítette, hogy az egyéni vállalkozók áfacsalás becslését éves gyakorisággal a vállalkozás szintü adóellenőrzés adatok alapján végzem, és a mutatók képzésében már több éves tapasztalattal rendelkezem. (Ritzlné Kazimir, 2014)

\subsection{Módszer}

A módszer fejezetben megvizsgálom a sokaság eloszlását a mintában és a teljes sokaságban. Ezután a lehetséges magyarázó változó struktúrákat határozom meg nemparaméteres tesztekkel. A következő lépés a sokaság heterogenitásának a vizsgálata és az outlier szürés. Végül a becslési eljárások közül ismertetem a sokasági jellemzőknek legjobban megfelelő két eljárást.

\subsubsection{Adatbázis vizsgálata}

Az alapadatbázisban lévő teljes sokaság tartalmazza az ellenőrzött vállalkozókat, ezen belül az áfacsalónak bizonyult vállalkozásokat. A becslési modell felépítéséhez előzetes vizsgálatok elvégzésére van szükség, ezeket foglalják össze a következő alfejezetek.

\subsubsection{Az ellenőrzési minta és a teljes sokaság összehasonlítása}

A mintával kapcsolatban két területen kell vizsgálatokat végezni.

Egyrészt számításba kell venni, hogy az adóellenőrzés adatbázis szisztematikus kiválasztás eredménye. Amennyiben nem megfelelően reprezentálja a sokaságot például egyes rétegekből nincs elég reprezentáns a mintában, akkor a teljes sokaságra nem készíthető felhasználásával becslés.

$\mathrm{Az}$ áfacsalás alapvetően két oldalról származhat. Egyrészt okozhatja az értékesítés aluljelentése, másrészt a költségek manipulálása, túljelentése. Az értékesítés az előzetesen felszámított áfát, a költségek a fizetendő áfa szintjét határozzák meg. Emiatt megvizsgáltam a teljes sokaságban és az adóellenőrzés állományban a fizetendő és az előzetesen felszámított áfa empirikus eloszlását.

A két mutató eloszlását a szokásos leíró statisztikákkal elemzem.

Másrészt az ellenőrzés minta - a NAV ellenőrzési stratégiája alapján - számos különböző mintavételi eljárással kijelölt sokaság. Emiatt meg kell vizsgálni, hogy az egyes rétegek, 
az egyes kategóriák szerinti csoportok megfelelő számú elemet tartalmaznak-e. Az általam használt három kategória jellegü változó, azaz a régió, a nemzetgazdasági ág és a létszám kategória szerinti kereszt táblák elemzésével vizsgálom meg, hogy megfelelő nagyságú-e a minta.

\subsubsection{A változók eloszlása és kapcsolata}

A változók vizsgálata kapcsán első lépésként a normalitást teszteltem. Erre az egyik leggyakrabban alkalmazott eljárás a Kolmogorov-Smirnov teszt. A teszt nemparaméteres, egymintás változata arra alkalmas, hogy egy empirikus eloszlás illeszkedését tesztelje egy kiválasztott eloszláshoz, jelen esetben a normális eloszláshoz képest.

A tesztstatisztika kiszámításához az empirikus eloszlásfüggvény $F_{n}$ :

$F_{n}(x)=\frac{1}{n} \sum_{i=1}^{n} I_{[-\infty, x]}\left(X_{i}\right)$

ahol $n$ a megfigyelések száma, $X_{i}$ a sorba rendezett megfigyeléseket jelöli. $\sum_{i=1}^{n} I_{[-\infty, x]}\left(X_{i}\right)$ az indikátor függvény, ami 1 értéket vesz fel, ha $X_{i} \leq x$ és 0 különben. A Kolmogorov-Smirnov statisztika az adott (ebben az esetben normális eloszlású) kumulatív eloszlási függvényével számítható ki:

$D_{n}=\sup _{n}\left|F_{n}(x)-F(x)\right|$

ahol $\sup _{n}$ a különbséghalmaz szuprémumát jelöli.

A teszt hipotézisei:

$$
\begin{aligned}
& H 0: F_{n}(x)=F(x) \\
& H 1: F_{n}(x) \neq F(x)
\end{aligned}
$$

A változók kapcsolatának elemzése szempontjából a következő vizsgálatokat lehet elvégezni. 
4. táblázat: A változók közti kapcsolat mérésének lehetőségei

\begin{tabular}{|l|l|l|}
\hline Változók típusa & Kapcsolat & Mérőszám \\
\hline $\begin{array}{l}\text { Minőségi-minőségi } \\
\text { változók }\end{array}$ & Asszociáció & Cramer mutató \\
\hline $\begin{array}{l}\text { Mennyiségi- } \\
\text { mennyiségi változók }\end{array}$ & Korreláció & Korrelációs együttható \\
\hline $\begin{array}{l}\text { Minőségi és } \\
\text { mennyiségi változók }\end{array}$ & $\begin{array}{l}\text { Vegyes } \\
\text { kapcsolat }\end{array}$ & $\begin{array}{l}\text { Varianciaanalízis normális eloszlás esetén } \\
\text { Kruskal-Wallis próba, nem normális eloszlások } \\
\text { esetén } \\
\text { Man-Whithney próba, szintén nem normális } \\
\text { eloszlások esetén }\end{array}$ \\
\hline
\end{tabular}

Forrás: saját szerkesztés

A minőségi változók esetében azt vizsgáltam, hogy az ellenőrzöttek, ill. az áfacsalók sokaságára a nem-ellenőrzöttekhez, ill. a nem áfacsalókhoz képest van-e jelentős különbség. A vizsgálathoz a Cramer mutatót használtam fel. A Cramer-féle asszociációs együttható 0 és 1 közötti értékeket vehet fel. Akkor lesz az értéke nulla, ha a két minőségi változó független egymástól, 1 értéket pedig az egyértelmü megfeleltethetőség esetén veszi fel. (Hunyadi \& Vita, 2008, old.: 164)

A két mennyiségi ismérv szerinti lineáris kapcsolatot a lineáris korrelációs együtthatóval mérhetjük a legegyszerübb módon. A korrelációs együttható -1 és 1 közötti értékeket vehet fel. Nulla érték esetén a két változót korrelálatlannak nevezzük, azonban ez nem jelenti azt, hogy a két változó között nincs kapcsolat. (Hunyadi \& Vita, 2008, old.: 175)

A vegyes kapcsolat esetén szokás variancianalaízist végezni (analysis of variance, ANOVA). A variancianalízis a sokaságok átlagának azonosságát vizsgálja. Azonban a variancianalízis feltétele a változók normalitása, vagy legalábbis a szimmetrikus eloszlása. Mivel az itt vizsgált változók eloszlása korántsem normális és nem is szimmetrikus, emiatt az ANOVA vizsgálatot elvetettem. A varianciaanalízis alternatívája 
nem normális eloszlású változók esetében a Kruskal-Wallis próba. A próbát több sokaság összehasonlítására is el lehet végezni.

A próba hipotézisei:

H0: A vizsgált sokaságok mediánja megegyezik.

H1: A vizsgált sokaságok mediánja különbözik.

A Kruskal-Wallis próba a csoport adatainak rangsorolásán alapul. A tesztstatisztika a következő képlettel határozható meg:

$H=(N-1) \frac{\sum_{i=1}^{g} n_{i}\left(\bar{r}_{i}-\bar{r}\right)^{2}}{\sum_{i=1}^{g} \sum_{i=1}^{g}\left(r_{i j}-\bar{r}\right)^{2}}$

ahol $n_{i}$ az $i$ csoport elemszáma, $r_{i j}$ a $j$ elem összes elemből származtatott rangszáma az $i$ csoportban, $N$ pedig az összes elemszámot jelenti. Az $\bar{r}_{i}=\frac{\sum_{j=1}^{n_{i}} r_{i j}}{n_{i}}$ képlettel számítható ki, és $\bar{r}=\frac{1}{2}(N+1)$, vagyis minden $r_{i j}$ érték átlaga. A tesztstatisztika $\chi_{g-1}^{2}$ eloszlást követ elég nagy elemszám esetén. (Kruskal \& Wallis, 1952)

\subsubsection{Outlier szürés}

A kiugró értékek, outlierek vizsgálata minden statisztikai feladatnál kötelező. A kiugró értékek elemzése során döntést kell hoznunk arról, hogy milyen megfigyeléseket nevezünk outliereknek, és hogyan kezeljük ezeket az eseteket.

Az outlierek felbukkanása hibás adatnak, a valós eloszlás szélsőséges értékének (természetes variancia) vagy pedig hibás modellnek köszönhető. A hibás adatok a KSH adminisztratív adatokon alapuló adatbázisában nem jellemzők. A valós eloszlásokon szélsőséges (jelentősen nagy, mivel jobbra elnyúló eloszlásokról van szó) értékek a gazdasági adatokban előfordulnak, ezek a fajta outlierek nem okoznak problémát. A hibás modellnek köszönhető adatokat az áfacsalás becslés szempontjából érdemes jobban szemügyre venni. Az egymással szoros korrelációban álló változók az ellenőrzött, áfacsaló és nem áfacsaló vállalkozások működésének, technológiájának és csalási jellegzetességeinek hordozói. Azok a megfigyelések, amelyek ezektől a struktúráktól jelentősen különböznek, outliernek tekintendők. 
Az outlierek azonosítására modell alapú és modell független eljárások egyaránt alkalmasak. A nem modell alapú outlier azonosítás lehet például a pontdiagramok ábrázolása. Ez a típusú azonosítás nagy elemszám és sok változó esetén bizonytalan.

A modell alapú eljárás lehet például a változókra illesztett megfelelő regresszió reziduumainak vizsgálata alapján meghatározott outlier halmaz. A regressziós technikák alkalmazásának azonban számos feltétele van, amelyeket az adóellenőrzési minta nem teljesít. A sok, egymással korreláló változó kezelésére a faktor analízis kézenfekvő megoldásnak tünik.

A faktoranalízis olyan statisztikai módszer, amely a változók csoportosítására, struktúrájának felderítésére és a változók számának csökkentésére alkalmas. Az eljárás a változók közti korrelációkat, kovarianciákat kihasználva látens változókat állít elő az eredeti változók lineáris kombinációiként. A modell a felhasznált $x_{j}$ indikátor változók alakulását magyarázó, közvetlenül nem mérhető faktorokra épül. Az $x_{j}$ standardizált indikátor változó esetében a modell az alábbi szerkezettel írható fel:

$x_{j}=\lambda_{j 1} f_{1}+\lambda_{j 2} f_{2}+\cdots+\lambda_{j m} f_{m}+u_{j}(j=1,2, \ldots, p)$

ahol $f_{k}$ a zérusátlagú faktor, $u_{j}$ az $x_{j}$ változóhoz tartozó egyedi hiba faktor, $\lambda_{i k}$ az $f_{k}$ közös faktornak az $x_{j}$ változóra vonatkozó faktorsúlya. A faktormodell egyenletei speciális regressziós egyenletek. Az egyedi faktorok egymással páronként korrelálatlanok. A faktormodell becslésének megfelelőségét a Kaiser-Meyer-Olkin mérték alapján értékelhetjük. Ennek tapasztalati határa 0,8 , ez alatt a faktormodell becslése megkérdőjelezhető. (Hajdu, 2003)

A Kruskal-Wallis teszt alapján kialakuló változó struktúrával nemzetgazdasági áganként faktor analízist végeztem az adóellenőrzési állományon, és kiemeltem azokat a vállalkozásokat, amelyeknek a faktorváltozók szerinti értéke a faktorváltozók nulla átlagához képest legalább öt szórásnyival eltérnek. Az így kiemelt változókat külön kigyüjtöttem és megvizsgáltam, az outliernek tekintett szervezeteket eltávolítottam a sokaságból. A faktoranalízist a SAS Enterprise Guide programmal végeztem el.

\subsubsection{A becslési eljárás}

Az adóellenőrzési minta nem tekinthető véletlen mintának, a kiválasztási algoritmusok nem reprodukálhatók, ráadásul a minta kiegyenlítetlen. Bizonyos vállalkozási rétegek az 
egyes időszakokban túlreprezentáltak, míg másokat kevésbé von be az adóhatóság az ellenőrzött vállalkozások körébe.

További problémát jelent, hogy a változók eloszlása nem normális. Az adócsalás az irodalom áttekintésben leírtak miatt nem egységes mechanizmusra visszavezethető magatartásforma, ráadásul az adóalanyok természetesen mindent elkövetnek, hogy a tevékenység ne legyen felderíthető.

A regresszió alapú becslés kézenfekvő becslési technikának tűnik nyilvánvaló előnyei miatt. Egyszerü megérteni és interpretálni, széleskörben, régóta használt és közismert. Amennyiben a minta reprezentatív és lefedi a teljes populációt, jól használható elörejelzésre. Rugalmasan alakítható a becslési eljárás a körülményeknek megfelelően. Ugyanakkor a hátrányait is figyelembe kell venni. Feltétele a normalitás, a variancia homogenitása a magyarázó változók korrelálatlansága. Ezek miatt az okok miatt a regressziós megközelítések a becslés során nem használhatók. (White, Tompaiski, Vastaranta, \& Wulder, 2017)

A szervezetek éves beszámoló és áfa bevallás adatai alapján számos lehetséges magyarázó változó adódik, azonban a kapcsolat a változók és az áfacsalás jelensége között nem egyértelmü, hiszen a csalás rendkívül heterogén jelenség. Emiatt a vállalkozások áfacsalás szempontjából homogén csoportjainak a lehatárolása szinte lehetetlen feladat. Továbbá az éves beszámoló adatai között a multikollinearitás is jelentős, hiszen a bevétel, a költségek, a profit és a foglalkoztatás adatai semmiképpen sem tekinthetők függetlennek.

Az ilyen jellegü problémák megoldására alkalmasak a gépi tanulásos eljárások. A következő ábra a lehetséges eljárások csoportosítását tartalmazza.

\section{2. ábra: A gépi tanulásos eljárások csoportositása}




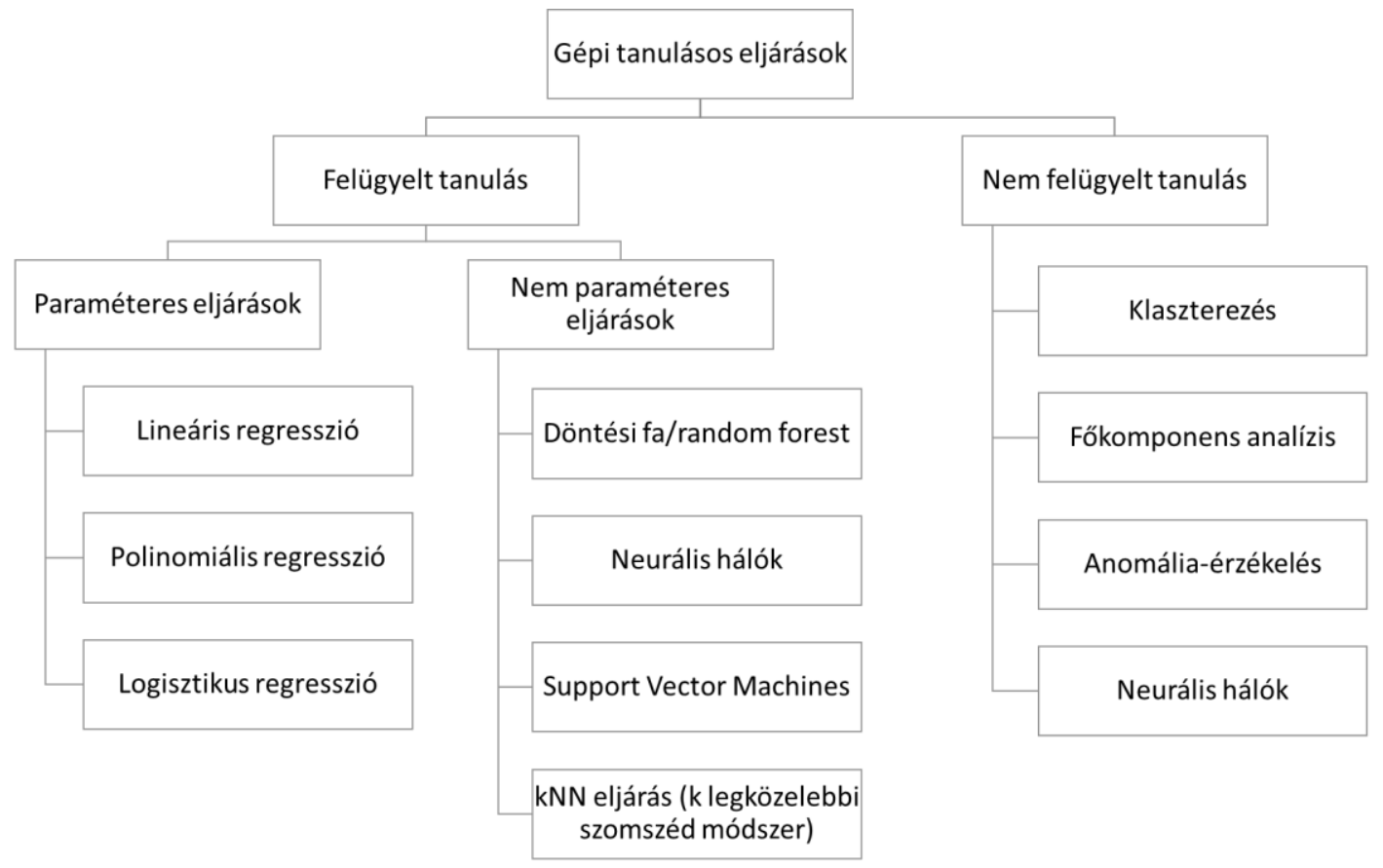

Forrás: saját szerkesztés

Az áfacsalás becslésére a gépi tanulásos eljárások közül a felügyelt tanulásos eljárások közül kell választani, hiszen az ellenőrzési minta alapján lehet becsülni azt, hogy ki áfacsaló és mekkora a csalás nagysága. Ennek oka a fentiekben már kifejtett heterogenitás jelensége.

Az eloszlások problémája miatt a paraméteres eljárások nem alkalmasak a becslésre ebben az esetben. Habár a mintavétel okozta gondokat a megfelelő súlyviszonyok meghatározása és súlyozott regressziók illesztése megoldhatná, azonban a szélsőségesen nem szimmetrikus és messze nem normális eloszlások ezek alkalmazását lehetetlenné teszik.

A nem paraméteres eljárások közül az adatbázisok nagyságát is figyelembe véve választottam becslési eljárást. A felsorolt eljárások közül a döntési fa és Support Vector Machines eljárások elsősorban klasszifikációs algoritmusok, itt viszont arány skálán mért folytonos változó, az áfacsalás becslése a cél. A neurális háló és a kNN eljárás egyaránt alkalmas az áfacsalás becslésére.

A kNN az egyik legegyszerübb klasszifikációs eljárás, amely a megadott metrika alapján kiszámítja az egyedek közti távolságot, és a besorolást a legközelebbi k szomszéd 
többségi besorolásai alapján becsüli. Az eljárás viszonylag régi, a k legközelebbi szomszéd szabályt, a klasszifikáció mintázatainak becslésére szolgáló eljárást Fix és Hodges fejlesztett ki 1951-ben. (Fix \& Hodge, 1951)

Az eljárás jól használható akkor, ha a változók eloszlásáról nincsenek információk, ill. többmóduszú sokaságok becslésénél ajánlott az alkalmazása. Az eljárás elönyei:

- kevesebb feltételnek kell megfelelni, mint a regresszió esetében

- nem kell a modellt felépíteni

- többféle változó esetében is használható

- nem szükséges teljes mértékben ismerni a magyarázó változók és az eredményváltozó közti kapcsolatot

- a változók közti multikollinearitás megengedett.

Az eljárás hátránya, hogy

- nem interpretálható

- az eljárás nem extrapoláción alapul, emiatt nagy minta szükséges hozzá, amely viszonylag jól lefedi a teljes sokaságot, különben az úgynevezett extrapolációs torzítás léphet fel

- az extrapolációs torzítás valószínübb a szomszédok számának növelésével

- érzékeny a mintaválasztásra. (White, Tompaiski, Vastaranta, \& Wulder, 2017)

A 23. ábra illusztrálja a kNN eljárás működését:

\section{3. ábra: A kNN módszer müködése}

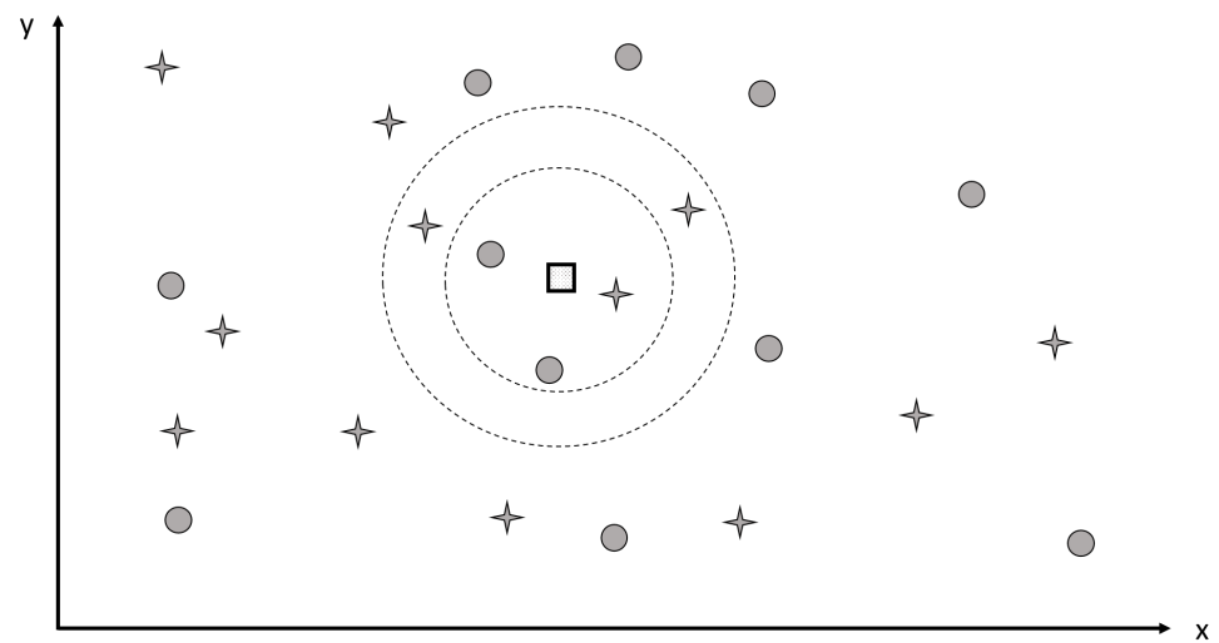

Forrás: saját szerkesztés 
Az eljárás a besorolni kívánt egyedek és az ún. tanuló sokaság (training set) megfigyelései közötti távolságot egy elöre meghatározott metrika alapján kiszámítja, majd a beállított szomszédszám függvényében besorolja a becsülni kívánt egyedet a megfelelő kategóriába. Például az előző ábrán, amennyiben három szomszéd alapján kívánunk dönteni a négyzet besorolásáról, akkor a besorolni kívánt egyed a kör besorolást kapja. Ha öt szomszéd alapján döntenénk, akkor pedig a csillag kategóriába kerülne. A távolságfüggvény használata miatt a numerikus változók sztenderdizálása szükséges, hogy a skálázási problémát elkerüljük.

A távolságmértékek szabadon megválaszthatók, az euklideszi és a Manhattan távolság gyakran alkalmazott a kNN eljárásban, de a Hamming vagy a Minkowski metrika egyéb változatai is használhatók. A Minkowski távolság egy általánosított távolságmérték, a következő képlettel számítható ki:

$\left(\sum_{i=1}^{n}\left|x_{i}-y_{i}\right|^{p}\right)^{\frac{1}{p}}$

Az általánosított szó itt azt jelenti, hogy a két pont ( $x$ és $y$ ) távolságát különböző $p$ paraméterekkel lehet kiszámítani. A Minkowski távolság speciális esete a Manhattan és az euklideszi távolságmérték, ekkor $p=1$ és $p=2$. A Hamming távolság szöveges változók értékei közti távolságot a karakterek pozíciója alapján határozza meg.

A kNN eljárást numerikus változók imputálására is lehet használni. Alkalmazása a kérdőíves adatfelvételek esetében a hiányzó válaszok pótlására széles körben elterjedt. Például Kanadában a Háztartási Költség Felmérés hiányzó adatainak imputálására is ezt az eljárást alkalmazzák. (Statistics Canada, 2018) Továbbá megfelelő feltételek mellett aszimptotikusan torzítatlan és konzisztens becslést eredményez. (Chen \& Shao, 2000) Az imputálás során a tanuló állományban (training set) szereplő szomszédok adott numerikus változójára vonatkozó valamilyen átlaga jelenti a becslést.

A 23. ábra példájából is látható, hogy az eljárás érzékeny a szomszédszám megválasztására. Túl kevés szomszéd alapján történő becslésnél a hibákat túlságosan nagymértékben veszi figyelembe, túl nagy szomszédszám választásnál pedig a csoportok nagyobb mértékben fognak keveredni a besorolási pontosság ellenében. Ezért érdemes több szomszédszám, vagy automatikus szomszédszám megválasztást választani a becslési folyamat során. 
Jelen esetben imputálási eljárásként használtam a kNN módszert úgy, hogy első lépésben az kNN-t az áfacsaló magatartás becsléseként futtattam, vagyis azt becsültem vele, hogy mely szervezet tekinthető adócsalónak. Ezután ennek az eljárásnak az eredményét is felhasználva a be nem fizetett adót becsültem szintén a $\mathrm{kNN}$ módszerrel. A becslési eljárást minden vizsgálatba bevont évre külön végrehajtottam.

A kNN módszert az SPSS programcsomaggal futtattam úgy, hogy az arányskálán mért változókat sztenderdizálta a beépített eljárás a következő módszerrel:

$x_{p n}=\frac{2\left(x_{p n}^{0}-\min \left(x_{p}^{0}\right)\right)}{\max \left(x_{p}^{0}\right)-\min \left(x_{p}^{0}\right)}-1$

itt $x_{p n}$ a normalizált $p$ változó értéke az $n$ megfigyelésre $x_{p n}^{0}$ az eredeti érték az $n$ megfigyelésre. $\min \left(x_{p}^{0}\right)$ a $p$ változó minimális, $\max \left(x_{p}^{0}\right)$ a maximális értéke. Az általam illesztett eljárás összes meghatározott változót felhasználta, a szomszédszám választás viszont automatikus volt.

Másik imputálásra használható eljárás a neurális hálókra épülő eljárás. Klasszifikációs és regressziós becslésekre is alkalmazható eljáráshoz az agyban lévő idegsejtek - neuronok - kapcsolódása volt a minta. A neurális hálózatokra épülő modell a biológiai hálózatok néhány tulajdonságát modellezi, de komplexitása természetesen attól jócskán elmarad.

\section{4. ábra: Példa egy kétszintü neurális hálózat felépítésére}

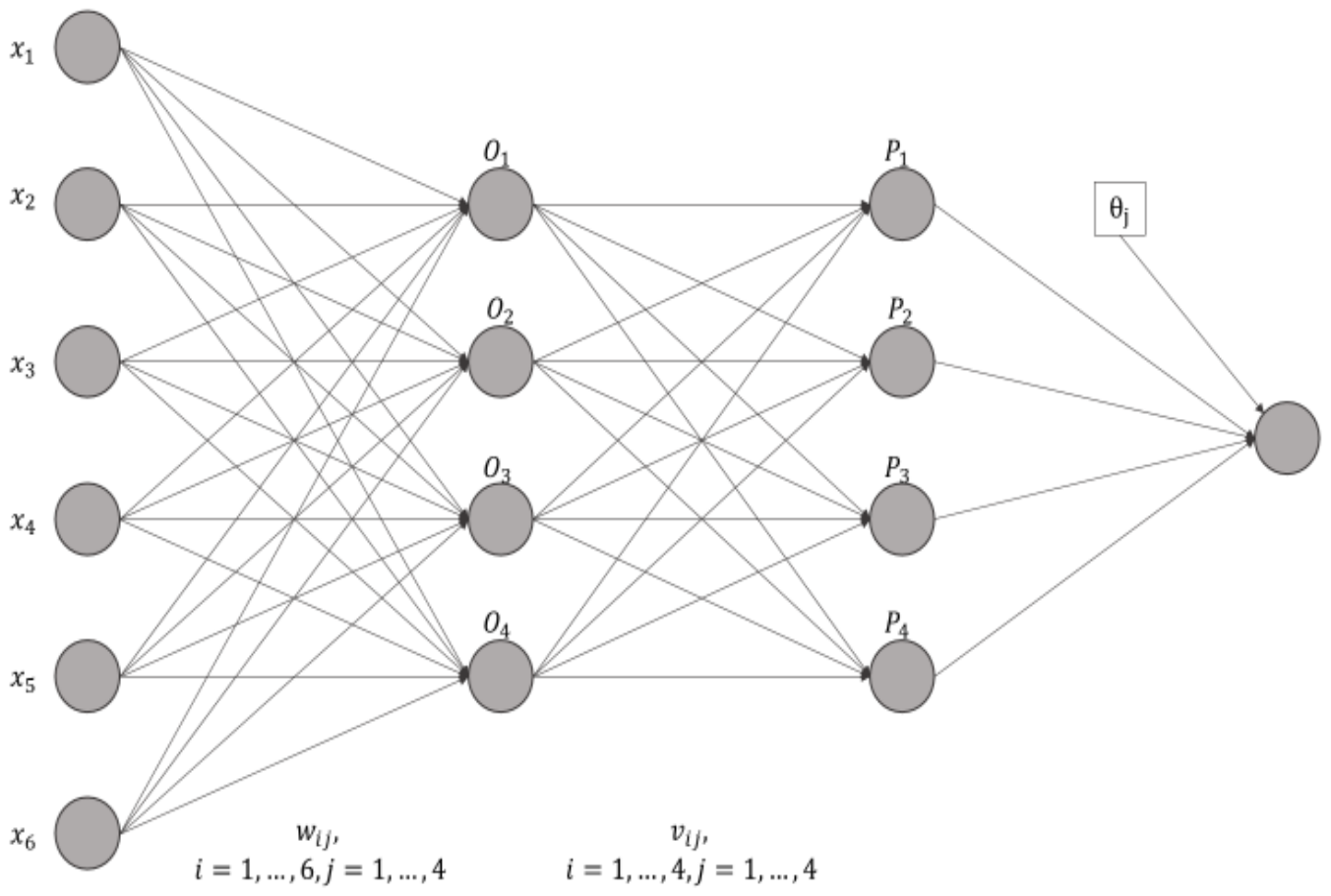

Forrás: saját szerkesztés 
A hálózat bemeneti oldalán felügyelt tanulási eljárás esetében a tanuló állomány (training set) attribútumai szerepelnek $\left(x_{i}\right)$. A 24. ábra olyan neurális hálót illusztrál, amelyben két rejtett réteg szerepel, $\left(O_{j}\right.$ és $\left.P_{j}\right)$. A csomópontok a biológiai hálózat neuronjainak feleltethetők meg. A rétegek közti átmenetet a súlyok biztosítják, az ábrán $w_{i j}$ és $v_{i j}$. Az egyes rétegek kimenete a következő réteg bemenetét jelenti, azonban az egyes rétegek kimenetén úgynevezett aktiválási függvényt alkalmaz az eljárás. Az aktiválási függvény a neuron állapotát, aktivitását határozza meg. (Han \& Kamber, 2004)

Aktiválási függvényként leggyakrabban szigmoid függvényt alkalmaznak. A szigmoid függvény a logisztikus függvény speciális esete, képlete a következő:

$f(x)=\frac{1}{1+e^{-1}}$

A többrétegü hálózatok alkalmasak komplex problémák megoldására, ezeket a hálózatokat „deep learning” neurális hálóknak nevezzük.

Az eljárás előnyeit a következő felsorolás tartalmazza.

- A neurális hálózatok rugalmasan alkalmazhatók regressziós és klasszifikációs problémák megoldására egyaránt. Bármilyen adattípusra illeszthető az eljárás.

- Sok változót is jól tud kezelni és nemlineáris problémák megoldására is jól használható.

- Az eljárás maga erőforrásigényes a tanulási fázisban, de az előrejelzés rendkívül gyors.

- A változók száma és a hálózat topológiája tetszőlegesen megválasztható.

A hátránya, hogy

- nem interpretálható az eljárás, a bemeneti változók és a végeredmény közötti kapcsolat „fekete doboz”

- erőforrásigényes

- a tanulóállomány szerepe jelentős az eljárás esetében, over-fitting és általánosítási problémákhoz vezethet. (Ciaburro \& Venkateswaran, 2017)

A deep learning neurális hálókat számos különböző területen használják, alkalmazható a hangfelismeréstől kezdve akár a rák diagnosztizálásáig. Ugyanakkor a hivatalos statisztika területén használata nem elterjedt. Jellemzően még keresik a statisztikai 
hivatalok a neurális hálókra épülő modellek felhasználási lehetőségekeit, míg a kNN módszer a hivatalos statisztikában gyakrabban használt eljárás.

\subsubsection{Panel modell}

A becslés eredményeként egyedi becslési eredmények állnak elő. A gépi tanulásos becslési eljárás nem interpretálható, az egyes tényezők hatása nem, vagy csak nehezen mutatható ki. Bizonyos tényezők az egyes vállalkozások szintjén nem is értelmezhetők. Ilyen például a gazdasági növekedés vagy a reáljövedelem, amelyek szintén hatást gyakorolhatnak az adócsalás szintjére.

Ezért a becslés egyedi eredményeit érdemes további vizsgálatnak alávetni. Kézenfekvő a területi és időbeli összehasonlítás. Az áfacsalás becslésének eredményei könnyen területi szintre aggregálhatóak, és területi szinten a területi áfarés vizsgálata érdekes. A területi és az idősoros bontás két dimenzióban teszi lehetővé az összefüggések vizsgálatát. Az ilyen adatsort panel adatnak nevezzük, elemzésére a panel regressziós analízis a megfelelő módszer.

A panel adat regressziós analízis alapegyenlete a következő:

$y_{i t}=a_{i}+b x_{i t}+\varepsilon_{i t}, \quad t=1,2, \ldots T$

ahol $y$ a függő, $x$ a független változó, $a_{i}$ és $b$ a regresszió koefficiensei, $i$ és $t$ az egyedi és időt azonosító indexek. Az $\varepsilon_{i t}$ a hibatagot jelöli. A panelmodelleknek háromféle alaptípusa létezik:

1. pooled panel modell

2. random effect modell

3. fixed effect modell.

A pooled panel modell szerint az adathalmazon belül az egyedeknek $(i)$ nincsenek egyedi tulajdonságaik, és nincs univerzális hatás időben. Ekkor minden $y_{i t}$ megfigyelés függetlennek tekinthető.

A fixed effect modell esetében az adathalmazon belül az egyedeknek vannak meghatározott tulajdonságaik, amelyek nem változnak időben. Vagyis ekkor az alapegyenletben a konstans paraméter minden $i$ egyedre külön meghatározott, és azt minden $i$-re becsüli az eljárás. A fixed effect modell esetében megengedett, hogy az $a_{i}$ paraméterek és az $x_{i t}$ között legyen korreláció. 
A random effect modell az $a_{i}$ értéket véletlen változóként és nem olyan paraméterként kezeli, amelyet becsülni kell. A random effect úgy is tekinthető, mint amikor a megfigyelt magyarázó változók és nem megfigyelt hatás közti korreláció nulla, $\operatorname{Cov}\left(x_{i t}, a_{i}\right)=0, t=$ $1,2, \ldots, T$.

Az $a_{i}$ paraméter különböző elnevezéseivel lehet találkozni a gyakorlatban, mint nem megfigyelt komponens, látens változó, nem megfigyelt heterogenitás, egyedi hatás, egyedi fix hatás. (Wooldridge, 2002)

A random és a fixed effect között a Hausman teszt segítségével lehet választani. A Hausman teszt hipotézisei:

H0: a random effect modell preferált a vizsgált modellre

H1: a fixed effect modell preferált a vizsgált modellre.

A Hausman teszt tesztstatisztikája a következők szerint számítható ki:

$H=\left(\hat{\delta}_{F E}-\hat{\delta}_{R E}\right)^{\prime}\left[A \widehat{\operatorname{var}}\left(\hat{\delta}_{F E}\right)-A \widehat{\operatorname{var}}\left(\hat{\delta}_{R E}\right)\right]^{-1}\left(\hat{\delta}_{F E}-\hat{\delta}_{R E}\right)$

ahol $\hat{\delta}_{F E}$ a fixed effect-re vonatkozó becslés $M \times 1$ elemü vektora, $\hat{\delta}_{R E}$ a random effectre vonatkozó becslés $\times 1$ elemü vektora. $A \widehat{v a r}\left(\hat{\delta}_{F E}\right)$ és $A \widehat{v a r}\left(\hat{\delta}_{R E}\right)$ a fixed és a random effect becslés aszimptotikus varianciáját jelöli. A Hausman teszt aszimptotikus $\chi_{M}^{2}$ eloszlást követ. (Wooldridge, 2002)

$\mathrm{Az}$ általam a területi áfarés adatokra illesztett panel modellben tehát első lépés lesz a Hausman teszt vizsgálata. Az ez alapján illesztett random vagy fixed effect modellben az egy főre jutó reál GDP lesz a magyarázó változó.

\subsection{4. Összefoglaló}

Az alapadatbázis vizsgálata során megvizsgáltam az ellenőrzési minta és a teljes sokaság legfontosabb mutatóinak hasonlóságát. Ezután következett a lehetséges magyarázó változók vizsgálata. Mivel a gazdaságstatisztikai változók nem normális, hanem balra ferde (jobbra hosszan elnyúló) eloszlást követnek, emiatt az ANOVA nem alkalmas arra, hogy az ellenőrzésre kiválasztott, a többi szervezet, illetve az áfacsalók és a nem áfacsalók közti különbségeket elemezhessük vele. Emiatt a nemparaméteres tesztek közül a Kruskal-Wallis tesztet végeztem el. 
Ezt követően az outliereket szürtem az ellenőrzött vállalkozások közül. A hagyományos outlier szürési technikák nem használhatók ebben az esetben, ezért a lehetséges változókat faktor analízissel faktorokba rendeztem nemzetgazdasági áganként. A faktorok alapján szélsőséges változókat tekintettem outliernek.

Végül a becslési eljárások közül a nemparaméteres gépi tanulásos eljárásokra esett a választásom. Ezt indokolta az áfacsalás heterogenitása és a magyarázó változók jelentős száma. A nemparaméteres eljárások közül a kNN, a k legközelebbi szomszéd eljárás és a többrétegü neurális hálózat alapján történő becslés jöhet számításba, mert ezek alkalmasak arányskálán mért változók becslésére.

A neurális hálós modell alkalmas lenne kNN becslés validálására. Azonban a neurális hálók struktúrájának az meghatározására az ilyen jellegü (csalás becslés) modelleknél nincs tapasztalat. Ezért becslésemet az Európai Bizottság megrendelésére készült áfarés becsléssel validáltam.

\subsection{Eredmények}

Az összefüzött adatbázis állományok külön adatbázis táblákban állnak rendelkezésre a vizsgálatok végrehajtásához. Mivel az állományok főként adminisztratív adatokból építkeznek, emiatt számos olyan szervezeti egység fordul elő a megfigyelések között, amely valószínüsíthetően nem végez valós tevékenységet, mert bár hivatalosan müködik, adminisztratív adatai nullák. Ezeket a szervezeteket a vizsgálatok előtt eltávolítottam az adatbázisból.

\subsubsection{Adatbázis vizsgálata}

Az adatbázis vizsgálata a teljes sokaság és az ellenőrzési minta összehasonlítását, a változók eloszlásának, és kapcsolatuk vizsgálatát és az outlier szürést foglalja magában.

\subsubsection{Az ellenōrzési minta és a teljes sokaság}

Az alábbiakban egy kiválasztott évre, 2012-re mutatom be a hisztogramokat két kiválasztott mutatóra vonatkozóan. A 25. ábra az előzetesen felszámított áfa eloszlását tartalmazza a teljes sokaságra és az ellenőrzött vállalkozásokra. Az ábráról jól látható, hogy az eloszlás jobbra hosszan elnyúló (balra ferde). (A szélsőséges értékeket az ábra nem tartalmazza.)

\section{5. ábra: Az elözetes felszámított áfa (millió Ft) relatív gyakorisága a teljes} sokaságban és az ellenőrzési adatbázisban 2012-re (\%) 


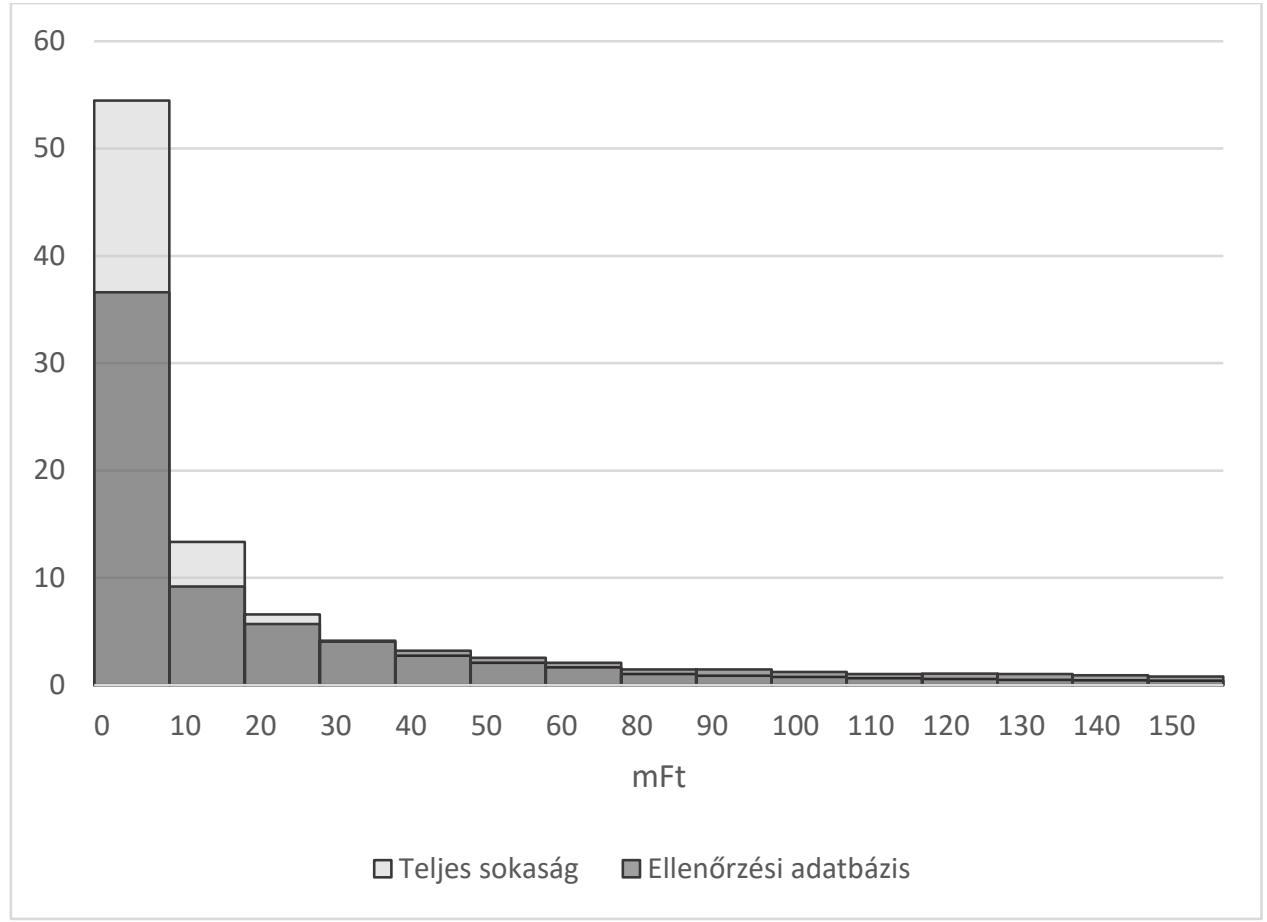

Forrás: saját szerkesztés

A 25. ábra alapján az elemzésbe bevont vállalkozások több mint 50\%-a 10 millió Ft alatti előzetesen felszámított áfát állapított meg 2012-re. Ugyakkor az ellenőrzési állományban a 10 millió Ft alatti előzetesen felszámított áfával rendelkező vállalkozások aránya nem éri el a 40\%-ot. Az előzetesen felszámított áfa vonatkozásában az ellenőrzési állomány magasabb arányban tartalmazza a nagyobb előzetesen felszámított áfával rendelkező vállalkozásokat. A fizetendő áfa szempontjából hasonló a helyzet. 
26. ábra: A fizetendö áfa (millió Ft) relatív gyakorisága a teljes sokaságban és az ellenörzési adatbázisban 2012-re (\%)

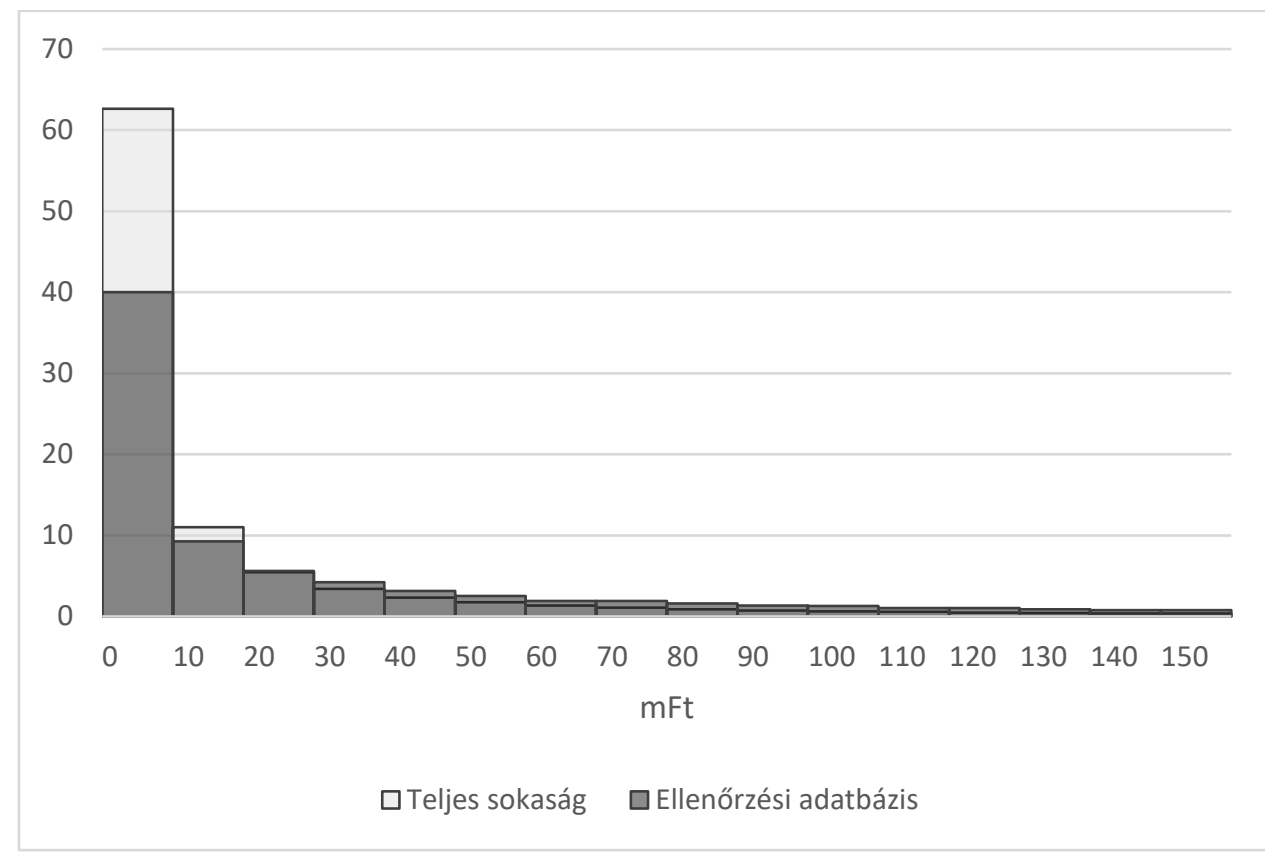

Forrás: saját szerkesztés

A vállalkozások közel 60\%-a 10 millió Ft alatti fizetendő áfát állapított meg 2012-ben, míg az adóellenőrzés mintában az ilyen vállalkozások részaránya mindössze $40 \%$ körüli (26. ábra). Ez azt jelenti, hogy - hasonlóan az előzetesen felszámított áfához - a fizetendő áfa esetében az ellenőrzöttek között a kisebb vállalkozások relatív gyakorisága alacsonyabb. A két mutató eloszlása a teljes sokaságban és a ellenőrzési állományban nem azonos, de meglehetősen hasonló.

Tekintetbe véve, hogy a jelenségről nem lehet más forrásból, például kérdőíves felmérésből jobb illeszkedésű adatokhoz jutni, és a két legfontosabb mutató eloszlásában nincs jelentős különbség, továbbá a minta nagynak tekinthető, ezért a rendelkezésünkre álló állomány megfelel a vizsgálat céljainak.

A két kiválasztott mutató leíró statisztikáit tartalmazza a 5. táblázat a 2012-es évre. 
5. táblázat: A fizetendö és elözetesen felszámított áfa fontosabb mutatói, 2012.

\begin{tabular}{|l|r|r|r|r|}
\hline & \multicolumn{2}{|c|}{ Fizetendö áfa } & \multicolumn{2}{|c|}{ Elözetesen felszámított áfa } \\
\cline { 2 - 5 } & Ellenörzött & Nem ellenörzött & Ellenörzött & Nem ellenörzött \\
\hline Szervezetek száma & 25468 & 370744 & 25468 & 370744 \\
\hline Átlag (eFt) & 535 & 111 & 365 & 74 \\
\hline Szórás (eFt) & 3121 & 2844 & 1914 & 1804 \\
\hline Terjedelem (eFt) & 195519 & 784261 & 112667 & 423758 \\
\hline Medián (eFt) & 27 & 8 & 21 & 5 \\
\hline Forrás: Saját szerkesztés & & & &
\end{tabular}

A 5. táblázatból jól látható, hogy a két kiválasztott mutató mindkét sokaságban balra ferde (jobbra elnyúló) eloszlású, ill. hogy az adóhatóság a nagyobb vállalkozásokat az ellenőrzési folyamatban felülreprezentálja. Az ellenőrzött vállalkozások között azonban a két kiválasztott mutató terjedelme jelentősen kisebb, mint a nem ellenőrzött vállalkozások között. A legnagyobb adóteljesítményű adózókat a 4/2012. (II. 14.) NGM rendelet a NAV a Kiemelt Adózók Igazgatóságán keresztül folyamatosan vizsgálja, háromévente jogkövetési vizsgálatot tartanak minden ide sorolt adózónál. Az a szervezet kerülhet ide, amelyik adóteljesítménye eléri a 3250 millió forintot, vagy pénzintézet (részvénytársasági formában), vagy biztosító társaság. Valószínűsíthető, hogy a kiemelt adózók áfacsalásának esélye a folytonos ellenőrzés következtében kicsi.

A 27. ábra az egyes évek mintanagyságát mutatja meg a teljes sokaság arányában. 
27. ábra: Az ellenörzésre kiválasztott szervezetek aránya az összes szervezethez viszonyitva, \%

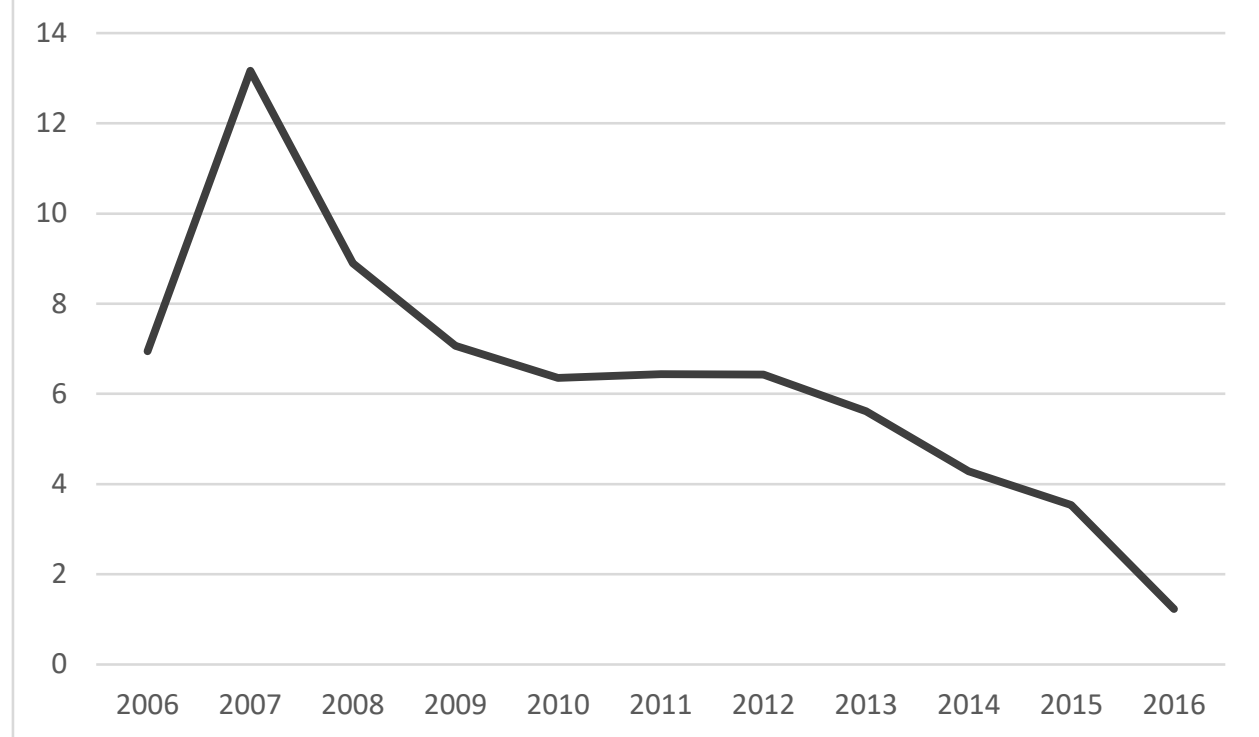

Forrás: saját szerkesztés

A rendelkezésemre álló mintát megfelelő nagyságúnak tartom. Érdemes megvizsgálni a minta eloszlását a minőségi változók szempontjából is. A következő, 6. táblázat a régiók és az ágazatok szerinti eloszlást mutatja meg.

6. táblázat: Az ellenőrzött és nem ellenörzött vállalkozások száma régiók és nemzetgazdasági ágak szerint, 2012

\begin{tabular}{|c|c|c|c|c|c|c|}
\hline & \multicolumn{2}{|c|}{$\begin{array}{c}\text { Északnyugat } \\
\text { Magyarország }\end{array}$} & \multicolumn{2}{|c|}{ Dél-Magyarország } & \multicolumn{2}{|c|}{$\begin{array}{c}\text { Északkelet } \\
\text { Magyarország }\end{array}$} \\
\hline & $\begin{array}{c}\text { Nem } \\
\text { ellenörzött }\end{array}$ & Ellenőrzött & $\begin{array}{c}\text { Nem } \\
\text { ellenőrzött }\end{array}$ & Ellenőrzött & $\begin{array}{c}\text { Nem } \\
\text { ellenőrzött }\end{array}$ & Ellenőrzött \\
\hline Mezőgazdaság & 6095 & 547 & 5937 & 530 & 5282 & 454 \\
\hline Ipar & 22635 & 1998 & 7717 & 683 & 7393 & 863 \\
\hline Építőipar & 23494 & 1729 & 7493 & 526 & 7751 & 744 \\
\hline Kereskedelem & 61118 & 4406 & 20095 & 1367 & 20063 & 1582 \\
\hline Szállítás & 10496 & 749 & 3450 & 265 & 3707 & 313 \\
\hline $\begin{array}{l}\text { Szálláshelyszolgáltatás, } \\
\text { vendéglátás }\end{array}$ & 13235 & 664 & 5155 & 237 & 4896 & 293 \\
\hline $\begin{array}{l}\text { Információ, } \\
\text { kommunikáció }\end{array}$ & 14486 & 723 & 1962 & 102 & 1743 & 92 \\
\hline Pénzügy & 709 & 76 & 152 & 14 & 147 & 32 \\
\hline Ingatlanügyletek & 19286 & 1451 & 2927 & 215 & 2467 & 237 \\
\hline Üzleti szolgáltatások & 50916 & 2651 & 9440 & 524 & 8712 & 534 \\
\hline $\begin{array}{l}\text { Közigazgatás, oktatás, } \\
\text { egészségügy }\end{array}$ & 6469 & 217 & 1516 & 55 & 1628 & 58 \\
\hline $\begin{array}{l}\text { Sport, szórakozás, } \\
\text { személyi szolgáltatások }\end{array}$ & 8833 & 352 & 1683 & 98 & 1656 & 87 \\
\hline
\end{tabular}

Forrás: saját szerkesztés 
A 6. táblázat adatai alapján a Pénzügy ágazatban rendkívül alacsony a mintaelemszáma. Ebben a tevékenységi körben kizárólag egyéni vállalkozók találhatók a vizsgálat szektorális lehatárolása miatt, továbbá a pénzügyi szolgáltatások tárgyi adómentességet élveznek, emiatt ebben a körben az áfacsalás amúgy sem valószínü. Hasonló a helyzet a Közigazgatás, oktatás, egészségügy nemzetgazdasági ágban is, itt is tárgyi adómentességet élvez a szolgáltatás. Végül a Sport, szórakozás, személyi szolgáltatások terén szintén számos olyan termék van, amely a tárgyi adómentesség kategóriájába tartozik. Ilyen például a sportolással kapcsolatos szolgáltatás nyújtás.

\subsubsection{A változók eloszlása és kapcsolata}

Az elemzésbe bevont szervezetek eloszlása szélsőségesen balra ferde, jobbra hosszan elnyúló. Ez általában jellemző a gazdaságstatisztikában mért változókra. A 4.2.1.2 alfejezetben bemutatott Kolmogorov-Smirnov teszttel vizsgáltam meg a változók eloszlását. A vizsgálatot SAS Enterprise Guide szoftverrel végeztem el, az eredmények a 3. függelék: A Kolmogorov-Smirnov teszt eredménye a vizsgálatba bevont változókra című táblázatban találhatók. A teszt eredménye alapján egyik változó sem tekinthető normális eloszlásúnak.

A változókat az ellenőrzésre kiválasztott és az ellenőrzöttek közül áfacsalónak bizonyuló vállalkozók vonatkozásában Kruskal-Wallis teszttel vizsgáltam. A vizsgálatba harminchat változót vontam be és nemzetgazdasági áganként végeztem el a tesztet az alábbi két hipotézisvizsgálatra:

A. teszt:

H0: Az ellenörzött és nem ellenörzött sokaság mediánja megegyezik.

H1: A vizsgált sokaságok mediánja különbözik.

B. teszt:

HO: Az áfacsaló és nem áfacsaló vállalkozók mediánja megegyezik.

H1: A vizsgált sokaságok mediánja különbözik.

Ez összesen 9216 teszt elvégzését jelenti. A tesztek eredményéből a jelenségek eltérő struktúrájára kívántam információkat gyüjteni. Az elvégzett tesztek alapján elmondható, hogy az ellenőrzött és nem ellenőrzött vállalkozások mediánja a vizsgálatba bevont vállalkozások esetében szignifikánsan különbözik a legtöbb változó esetében. A nemzetgazdasági ágak szerint a struktúra szintén kismértékü eltérést mutat. 
Ugyanakkor az áfacsalók és nem áfacsalók vonatkozásában a két sokaság nem különbözik a vizsgálatba bevont változók szempontjából. A szignifikáns eltérések a mediánok szempontjából inkább véletlenszerünek, mintsem szisztematikusnak tủnnek.

A Kruskal-Wallis teszt alapján elmondható, hogy az ellenőrzési mintába kerülést viszonylag jól lehetne becsülni a rendelkezésre álló folytonos változók alapján. Ráadásul az eltérést mutató változók struktúrája nemzetgazdasági áganként a vizsgált időszak alatt hasonló.

Azonban az, hogy egy szervezet adócsaló-e az elemzésbe bevont folytonos változók alapján nem becsülhető, mert a két sokaság között nagyon kevés változó esetében szignifikáns az eltérés és ezek a változók is évről évre más szerkezetet mutatnak.

A becslési módszertan kialakításakor kézenfekvőnek tűnt az a megközelítés, hogy a mintába kerülést és az adócsaló magatartást külön-külön egy-egy klasszifikációs eljárással becsüljem. A Kruskal-Wallis teszt eredményeként elvetettem ezt a lehetőséget, hiszen az adócsalókat becsléséhez a rendelkezésre álló magyarázó változók nem rendelkeznek szignifikáns magyarázó erővel.

A Kruskal-Wallis teszt eredménye külön adathordozón található.

\subsubsection{Outlier szürés}

Az outlierek kiválasztása során az adóellenőrzés állományból szürtem ki az outliereket.

Az outlier meghatározásához faktor analízist illesztettem az ellenőrzött vállalkozásokra. A faktoranalízist minden évre nemzetgazdasági áganként végeztem, a bevont változók köre a Kruskal-Wallis teszt alapján az adócsaló változó szempontjából szignifikáns magyarázó változók voltak. Emiatt a bevont változók évenként és ágazatonként eltérők voltak. A faktoranalízis során kiszámított kommunalitás mutatók a 2006, 2012 és 2016os évekre a 4. függelék 5. függelék és 6. függelék táblázataiban találhatók.

A faktorok alapján azokat az ellenőrzött vállalkozásokat tekintettem outliernek, amelyeknek az összes faktorváltozó értéke egyszerre kívül esik a faktorváltozó átlagától számított öt szórásnyi intervallumon.

A következő táblázat tartalmazza az outlier szürés eredményét. 
7. táblázat: Az outlierek száma és aránya az ellenőrzési állományon belül

\begin{tabular}{|c|c|c|}
\hline Évek & $\begin{array}{l}\text { Outlierek } \\
\text { száma }\end{array}$ & $\begin{array}{l}\text { Outlierek } \\
\text { aránya }\end{array}$ \\
\hline 2006 & 343 & 1,2 \\
\hline 2007 & 533 & 1,0 \\
\hline 2008 & 506 & 1,4 \\
\hline 2009 & 393 & 1,4 \\
\hline 2010 & 413 & 1,6 \\
\hline 2011 & 363 & 1,4 \\
\hline 2012 & 354 & 1,4 \\
\hline 2013 & 333 & 1,5 \\
\hline 2014 & 266 & 1,7 \\
\hline 2015 & 332 & 2,4 \\
\hline 2016 & 97 & 2,0 \\
\hline
\end{tabular}

Az outlierek száma nem extrém arányuk csak 2015-ben haladta meg a 2\%-ot.

\subsubsection{A becslési modell eredménye}

A fenti eljárással első lépésben az áfacsaló vállalkozásokat a vizsgált időszakra becsültem meg. Az áfacsalónak becsült vállalkozások halmaza még nem tekinthetők végeredménynek, a becslés célja az áfacsalás szintjének becslése volt. Ezt második lépésként becsültem meg a vizsgálatba bevont vállalkozásokra.

Mivel az áfacsalás is erösen függ a tevékenységtől, mérettől és egyéb tényezőktől, e lépésben is a kNN módszert választottam. Ennek az a hátránya, hogy a magyarázó változók és az eredményváltozó közötti kapcsolat, összefüggés nem számszerüsíthető, tesztelhető és interpretálható. Azonban tekintetbe véve, hogy az áfacsalás mennyire heterogén, az egyes szereplők motivációi és magatartása (lásd a 2.2 fejezetet), ill. az adócsalás konkrét megjelenése (pl. számla nélküli értékesítés vagy költségek túljelentése, hogy csak a legegyszerübbeket említsük) annyira különböző, hogy az összefüggések ilyen esetekben nem is interpretálhatók egyszerüen.

Az áfacsalás becslésére neurális hálóra épülö modellt is illesztettem. Azonban a modell még többszintü neurális háló esetén sem hozott értékelhető eredményt. Ezért a fejezetben a neurális hálókra épülő sikertelen modellek eredményét nem mutatom be.

A becslés eredményességének nincs olyan egyértelműen meghatározható kritériuma, mint amilyen a paraméteres becslések esetén a rendelkezésre áll. A klasszifikációs eljárásoknál használatos besorolási mátrix ill. ROC görbe, ami a helyes és helytelen 
besorolások közti összefüggést mutatja meg, ebben az esetben nem használható. A következő ábrán (28. ábra) azt ábrázoltam, hogy az adóhatóság által megállapított áfa ellenőrzések eredményéhez képest a becslési eljárás mennyire jó eredményre vezet.

\section{8. ábra: Az ellenörzési mintában lévö vállalkozásokra becsült be nem fizetett áfa} megoszlása.

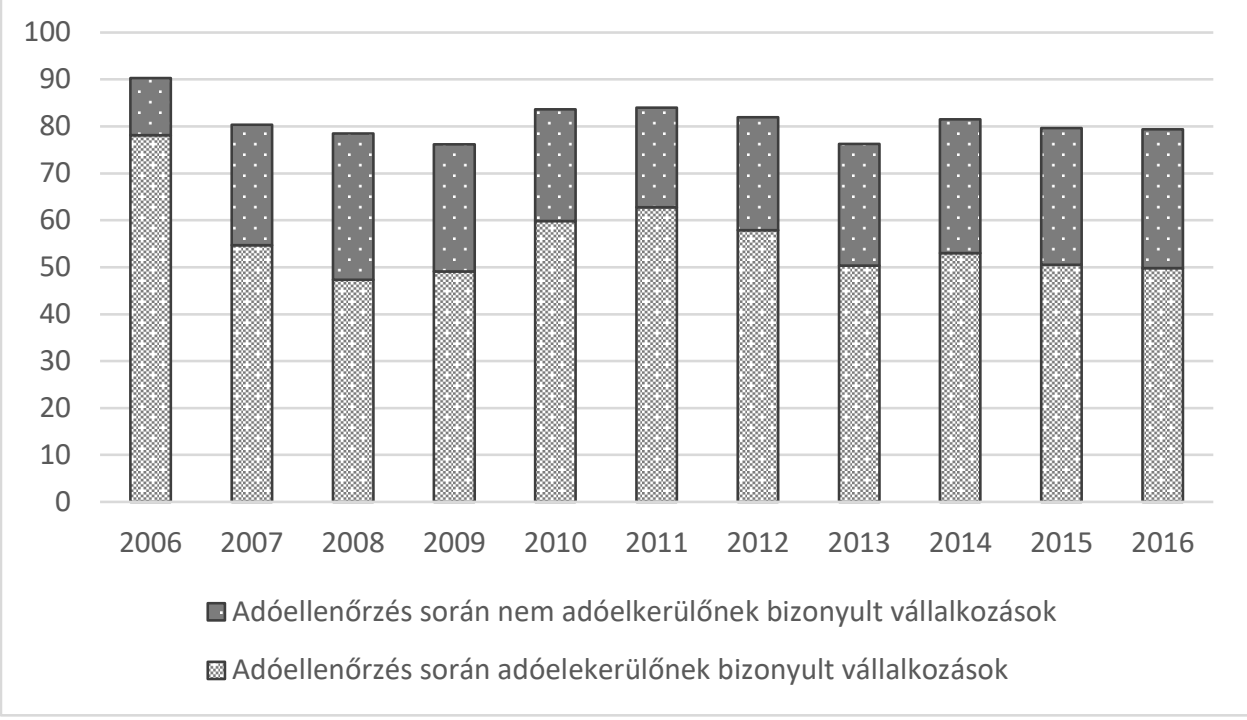

Forrás: saját szerkesztés

Az áfaellenőrzések során áfacsalónak bizonyult vállalkozásokra megállapított befizetendő adó nagyságát az általam használt modell általában 50\%-nál nagyobb pontossággal becsülte meg. Az áfacsalókra és nem áfacsalókra becsült többletadó a NAV által megállapított többletadó közel 80\%-a volt a vizsgált időszakban.

Az általam alkalmazott eljárás az adócsalás becslésére nem lenne alkalmas, amennyiben a vállalkozás szintű adócsalás becslése lenne a cél. Azonban úgy vélem, hogy a makroszintü becsléshez az eljárás jó eredményre vezet.

\subsubsection{A be nem fizetett áfa alakulása nemzetgazdasági áganként}

A becsült eredmények nemzetgazdasági ágak szerinti megoszlása a 29. ábra alapján látható: 
29. ábra: A becsült áfacsalás alakulása és nemzetgazdasági ágak szerinti megoszlása, $2006=100 \%$

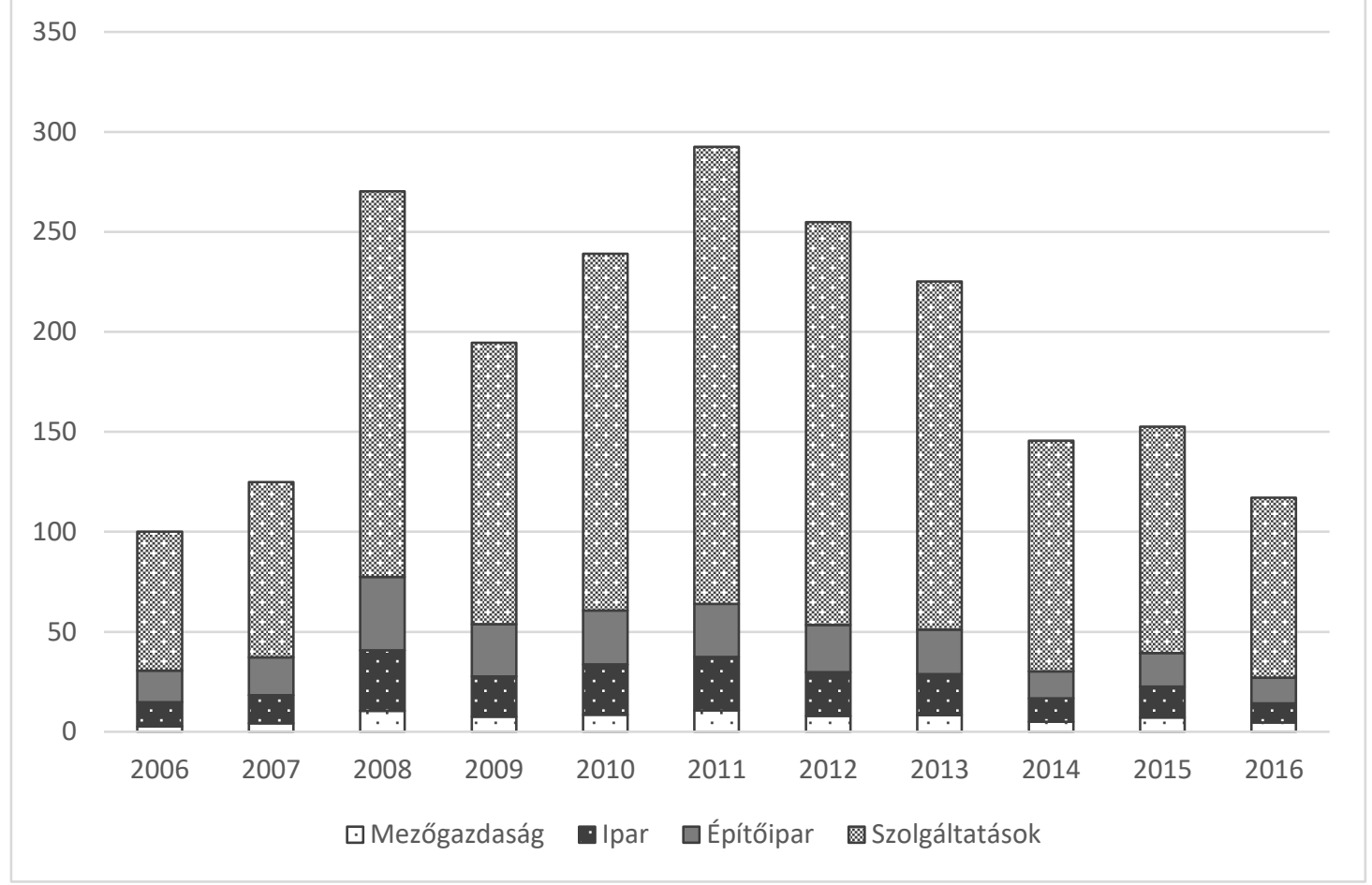

Forrás: saját szerkesztés

A becsült áfacsalás 2006-hoz viszonyítva 2011-ig dinamikusan nő. Kiugró érték a válság első éve, 2008. 2012-től csökkenő tendencia bontakozik ki, 2015-ben kisebb megtorpanással.

A nemzetgazdasági ágak közül kimagasló a szolgáltatásokon belül a kereskedelem nemzetgazdasági ág. Itt a legjelentősebb a becsült áfacsalás. Különösen a 2011-2013 közti időszakban volt kimagasló az aránya. 2014-től azonban a becsült áfacsalás nem csak a kereskedelemben, hanem a többi nemzetgazdasági ágban is jelentősen csökkent. Véleményem szerint ezt az online kasszák bevezetésének szétterjedő hatása magyarázhatja.

A becsült áfacsalás jelentős méreteket ölt még az adminisztratív szolgáltatások és az építőipar nemzetgazdasági ágakban. Az iparban becsült áfacsalás szintje közel hasonló az építőiparéhoz. A jelenség azonban közel sem okoz ugyanakkora jelentőségü problémát, tekintve, hogy az ipar nemzetgazdasági súlya az építőiparénak többszöröse. 


\subsubsection{Az áfarés alakulása}

Az áfacsalás abszolút szintjének elemzése nem ad teljes képet a jelenség alakulásáról, hiszen ezek folyó áras adatok, a relatív szint többet árul el az alakulásról. Sokkal informatívabb, ha a befolyt áfa és a becsült áfacsalás összegéhez (elméleti vagy teoretikus áfa) hasonlítjuk a szintjét, és így az áfaréshez hasonló arányt kapunk. A 30. ábra az így képzett áfarés és az Európai Bizottság által publikált áfarés alakulását tartalmazza a vizsgált időszakra.

30. ábra: Az áfarés alakulása és a becslési eredmény, \%

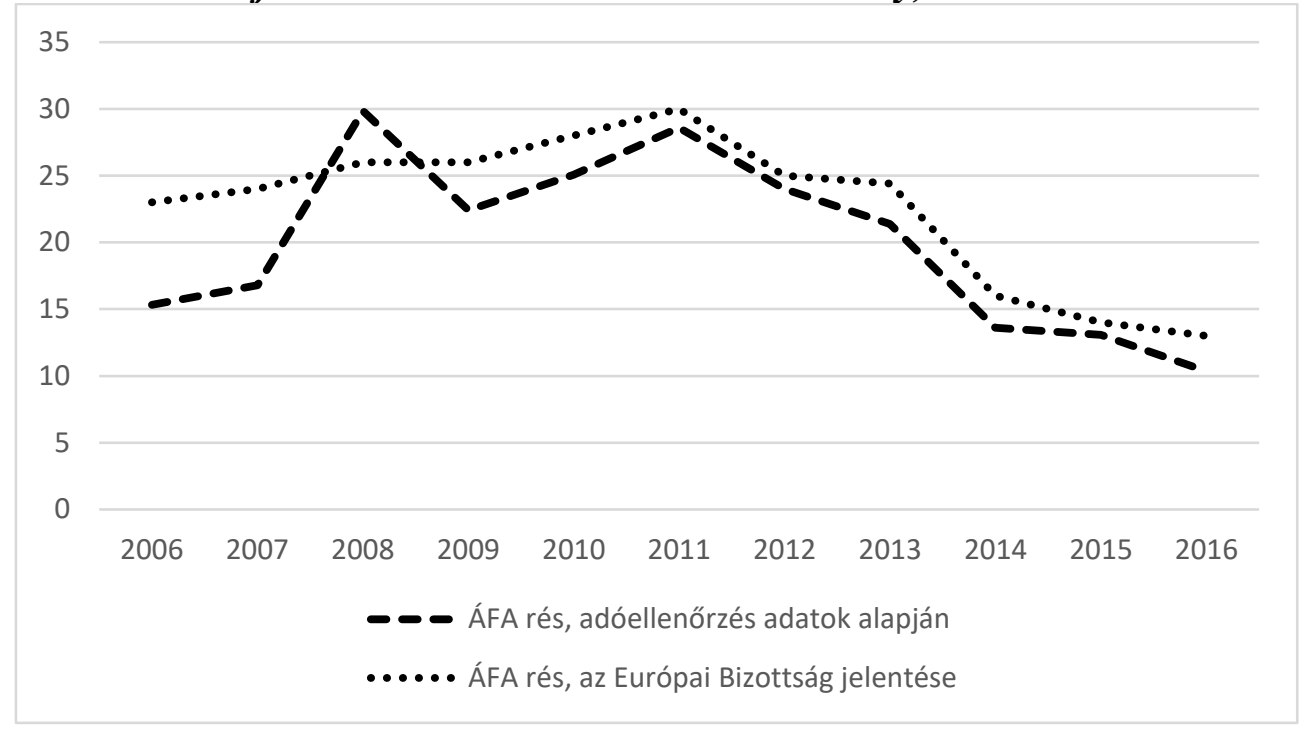

Forrás: (Reckon, 2009), (Európai Bizottság, 2012-2018), saját szerkesztés

Az előző ábrán a 2008-as év kivételével az Európai Bizottság által közzétett áfarés magasabb a becslésünkhöz képest. Ennek az az oka, hogy az Európai Bizottság megbízásából készült tanulmány minden olyan tevékenységet figyelembe vesz a teoretikus áfa számítása során, amelyre vissza nem igényelhető áfa keletkezik, azaz benne vannak olyan tételek is, amelyek legálisan az adók átcsoportosításával, minimalizálásával érintettek. Továbbá a fizetésképtelenség miatt be nem szedett áfa kiszürése sem történik meg. A becslésem ugyanakkor csak olyan áfacsalásra fókuszált, amely jogszabály megsértésével jár együtt, emiatt szükebb tevékenységet fed le.

Összességében az általam becsült áfarés alakulása az Európai Bizottság jelentéséhez hasonló, a 2008-as év kivételével. A 2008-ra becsült jelentős áfacsalás az ebben az évben befolyt áfához viszonyítva jelentős, 30\%-os áfarést eredményezett. Az alacsony áfakulcsok, ill. a begyürüző világgazdasági válságnak köszönhető piacszűkülés miatt az áfacsalás az áfa bevételek relatív csökkenésével járt együtt. A 2009-ben, év közben 
megemelt áfakulcs erre a helyzetre reflektált, és így csökkenhetett a 2009-es becsült áfarés.

A 2011-es évben mindkét becslés szerint kiemelkedően magas volt az áfarés. Az Európai Bizottság jelentése szerint elérte a 30\%-ot. A gazdasági válság jelentős mértékben sújtotta az országot, a GDP, a fogyasztás és a beruházás jelentősen visszaesett. A rossz gazdasági környezet hatására a vállalkozások számára a szabálykerülő magatartás egyre vonzóbbá vált. Ugyanakkor a piac szükülése miatt az áfa bevételek sem növekedtek jelentősen. A széles körben elterjedt jelentős áfacsalás a költségvetési kockázaton túl azt a veszélyt is magában hordozza, hogy a szabálykerülő viselkedés elfogadott társadalmi normává válik és így állandósul. (Ariely, 2015) Ezért is volt szükség a kormányzati beavatkozásra.

A kormányzat 2012-től bevezetett intézkedései (az áfakulcsok megváltoztatása, egyéb adminisztratív intézkedések, az adóhatóság stratégiájának megváltoztatása) alapján elmondható, hogy jelentős erőfeszítéseket tett a vállalkozások szabálykövető magatartásának fokozására. Ebben az időszakban Magyarországnak sikerült kilábalni a gazdasági válságból. E két tényező elősegíthette az áfarés csökkenését, ami a 30. ábra alapján jól látható módon valóban jelentősen visszaesett 2016-ra.

\subsubsection{Az áfarés területi alakulása}

Ami az áfarés alakulását illeti, a becslés lehetőséget nyújt a területi szintü eredmények vizsgálatára is. Az általam összeállított adatbázisban a NUTS3 szintű területi kódok szerepelnek, amelyek megyei szinten mutatják meg a vállalkozások földrajzi elhelyezkedését.

A befizetett áfa nem áll rendelkezésre területi bontásban. Az áfa hozzáadott érték jellegü adó, nettó befizetése az adott termelési fázis hozzáadott értékétől függ. A rendelkezésemre álló adatbázis vállalkozás szinten tartalmazza a hozzáadott érték adatokat. ${ }^{14}$ Ennek területi arányában osztottam fel a KSH által a kormányzati szektor adatai között publikált (3.1.16.2 STADAT tábla) realizált áfa bevételek nagyságát.

\footnotetext{
${ }^{14}$ Ez a hozzáadott érték nem egyezik meg a nemzetgazdaság teljes hozzáadott értékével. Ennek oka, hogy az általam összeállított adatbázis a nem pénzügyi vállalatok és az egyéni vállalkozások adatait tartalmazza, ami a vállalati szektort és a háztartási szektor egy részét fedi csak le. Továbbá a bruttó hozzaádott érték nemzetgazdasági szinten számos olyan tételt is tartalmaz, amelyeket nem lehet vállalkozás szintre lebontani. (Murai, 2011)
} 
Az általam becsült áfacsalás nagyságát ehhez viszonyítottam, így kaptam meg a megyei szintű áfarés értékeket. A következő, 31. ábra a 2006. évi ragsort mutatja meg a megyei szintü áfacsalásra vonatkozóan.

31. ábra: A becsült megyei áfarés alapján meghatározott rangsor, 2006 (1=legalacsonyabb érték)

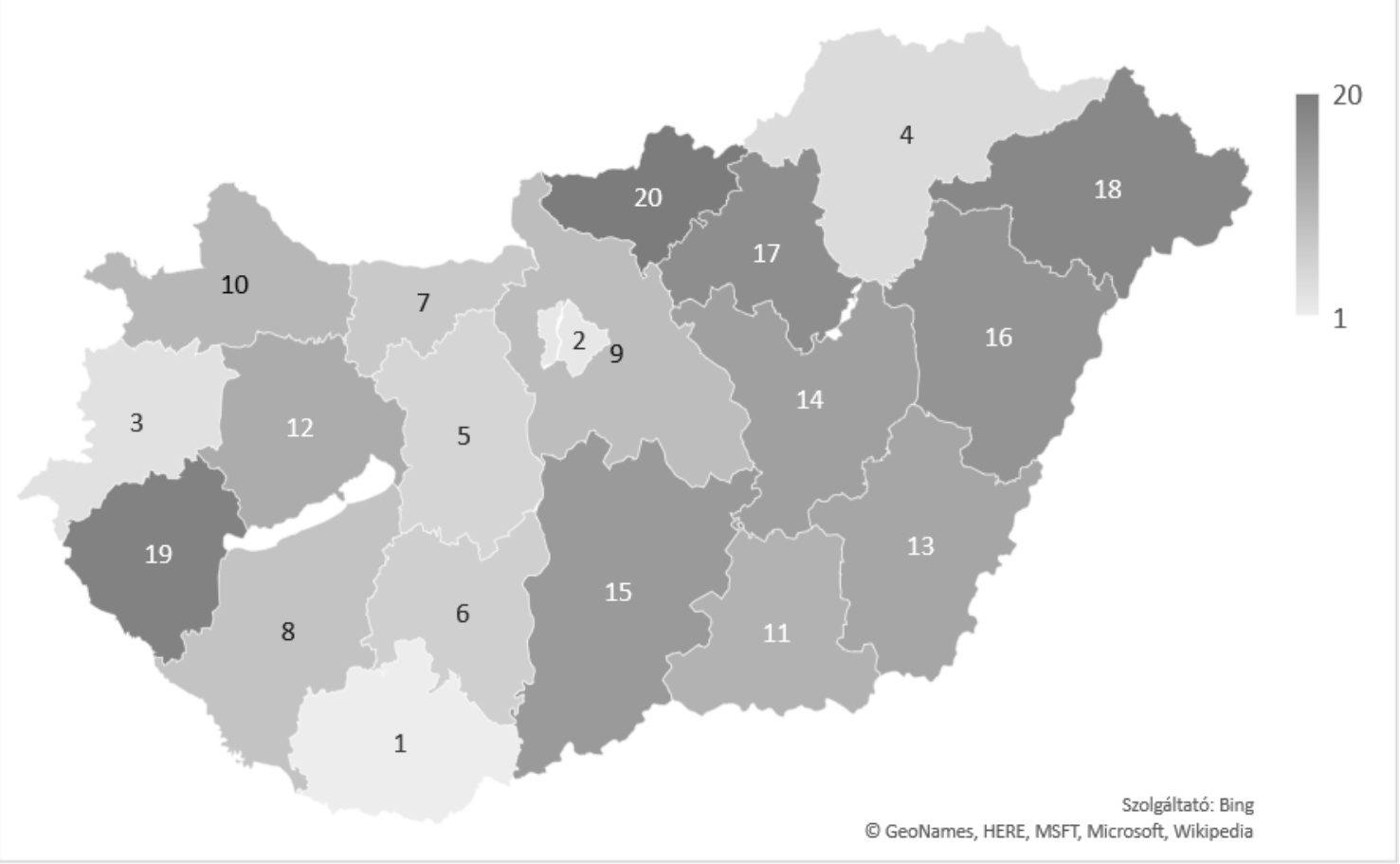

Forrás: saját szerkesztés

A legalacsonyabb áfaréssel Baranya, Budapest és Vas megye rendelkezett 2006-ban. Budapesten magas volt az egy főre jutó GDP, és számos nagyvállalat székhelye is itt található. Vas megyében Szentgotthárdon az Opel motorgyártó üzeme jelentős hozzáadott értéket jelent. A legmagasabb áfarés Szabolcs-Szatmár-Bereg megyében, Zala megyében és Nógrád megyében volt. Mindhárom megyében viszonylag alacsony a GDP, továbbá ki kell emelni, hogy 2006-ban az említett megyékben nem müködtek nagy, multinacionális vállalkozások.

A 2008-ban kirobbant pénzügyi válság sok területen változást eredményezett a magyar gazdaságban, így átalakította az áfacsalás területi eloszlását is. 


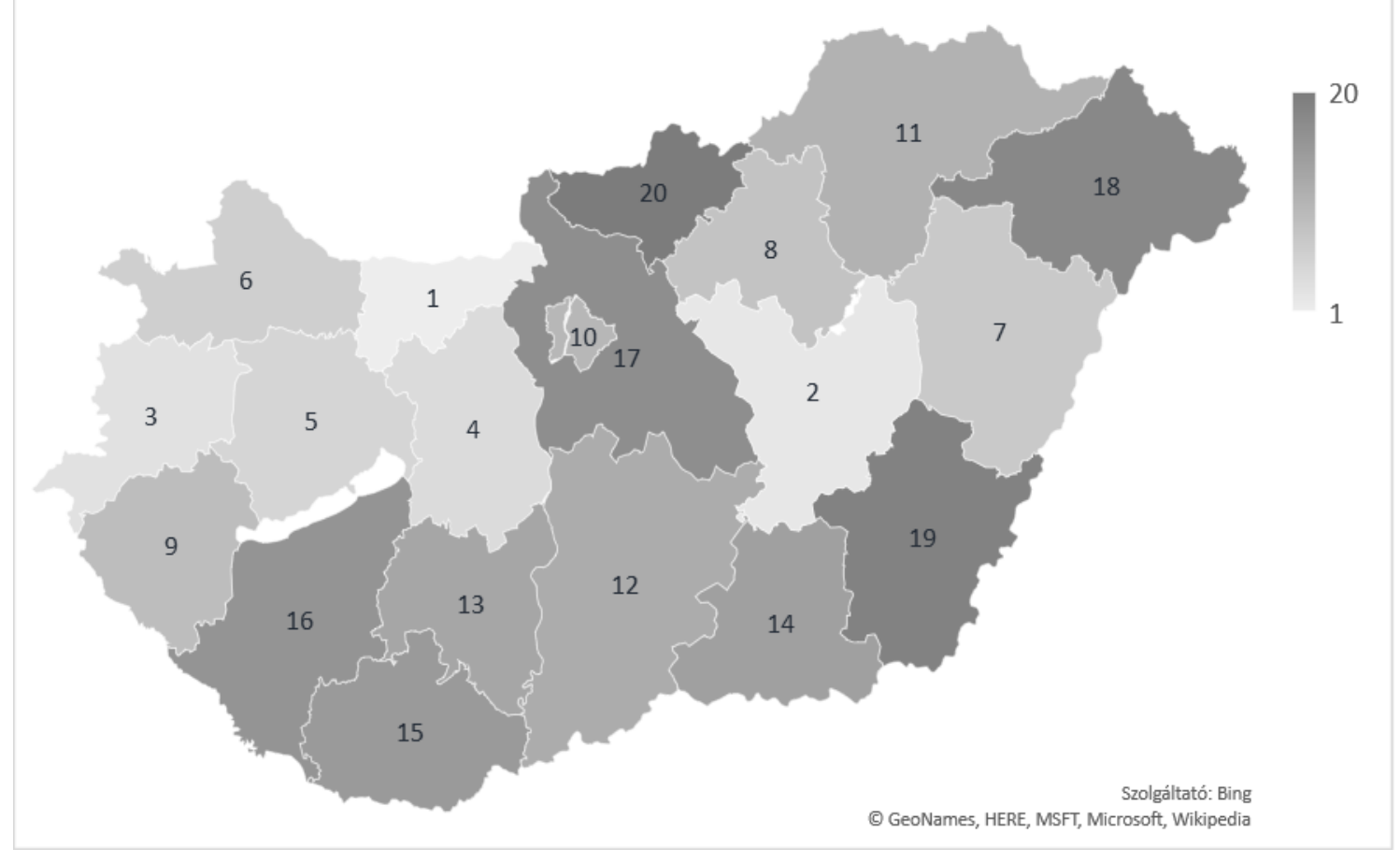

Forrás: saját szerkesztés

A válság következtében Magyarország integrációja a globális gazdaságba tovább mélyült. Az autóipar és beszállítóinak súlya megnőtt a hazai gazdaságban. Ugyanakkor a válság vége felé, különösen a mezőgazdaságban a lánc és egyéb áfacsalás elterjedté vált. Ezt a képet tükrözi a 32. ábra is. A jelentősebb autóipari érintettséggel rendelkező megyék (például Komárom-Esztergom, Vas, Győr-Moson-Sopron, Veszprém) a viszonylag magas hozzáadott értéknek és a nagyvállalati beszállítói hálózatba való integráltságnak köszönhetően relatíve alacsony áfaréssel rendelkeznek. A déli, jellemzően magasabb mezőgazdasági termeléssel rendelkező megyék egyaránt magasabb áfarést realizálnak. A lista végén Nógrád és Szabolcs-Szatmár-Bereg megye, ill. Békés megye található. Az első kettő 2006-ban is sereghajtó volt. Ki kell még emelni, hogy Budapest és Pest megye pozíciója jelentősen romlott 2006-hoz képest. Pest megye relatív helyzetének romlásához hozzájárulhatott a vállalkozások számának drasztikus emelkedése a megyében. 2006-hoz viszonyítva 2012-re 71\%-kal emelkedett a müködő korlátolt felelősségü társaságok száma, míg Budapesten a részvénytársaságok száma emelkedett az országos átlagnál nagyobb mértékben, 27\%-kal nőtt. (Stadat táblák, 2020) 
A megyei eloszlású adórés 2016-ra a 2012-höz képest jelentősen megváltozott, ahogyan azt a 33. ábra is mutatja.

33. ábra: A becsült megyei áfarés alapján meghatározott rangsor, 2016

(1=legalacsonyabb érték)

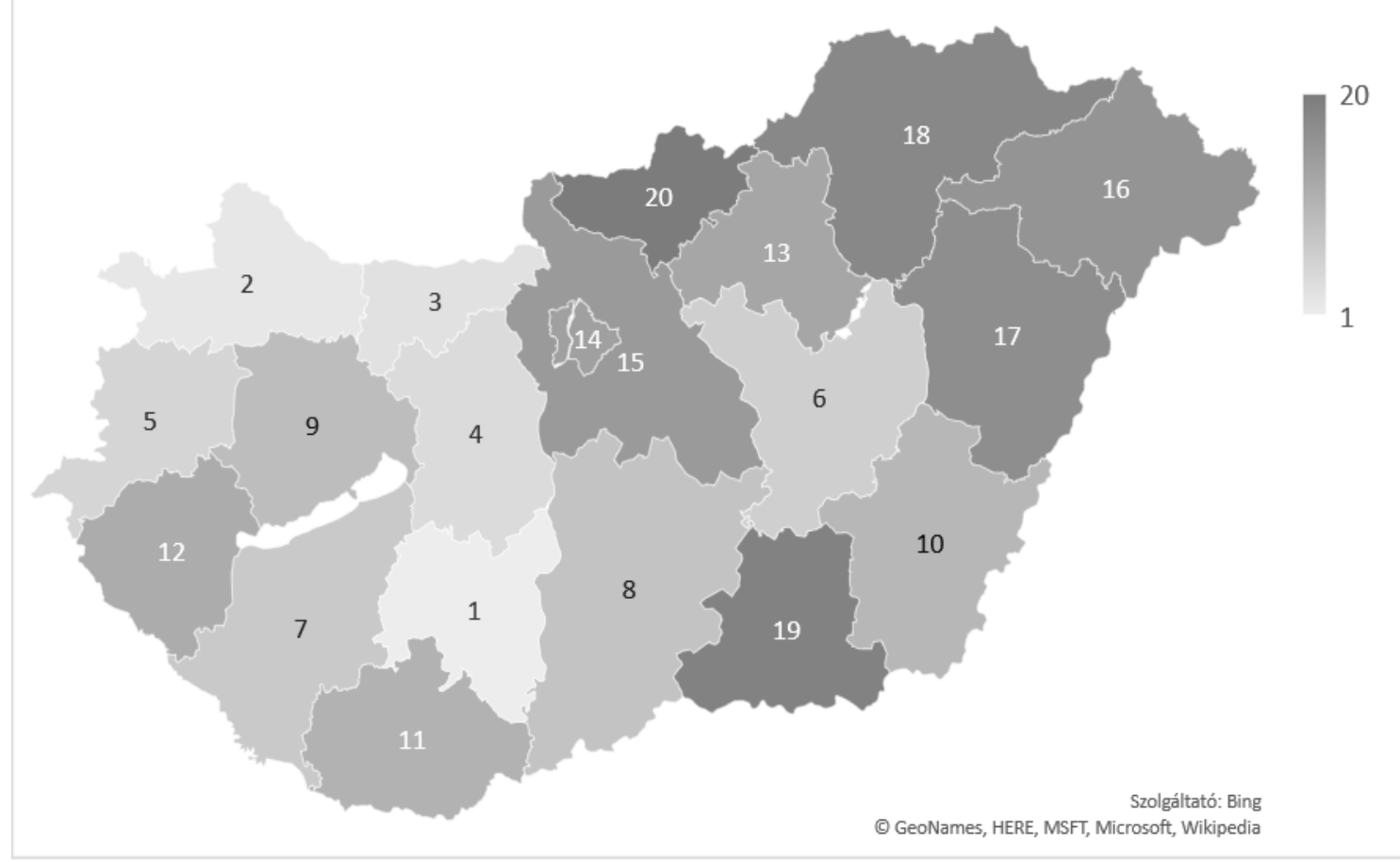

Forrás: saját szerkesztés

Az ábra alapján jól látszik, hogy az áfarés szempontjából az észak-keleti országrész rendelkezik jelenleg a legnagyobb arányú áfa hiánnyal. Nógrád megye továbbra is utolsó a rangsorban, legmagasabb áfarés arányával. Budapest és Pest megye közti különbség csökkent, a mezőny második felében foglalnak helyet. Az ország nyugati része megőrizte és erősítette vezető pozícióját az alacsony áfarés terén.

A 2012. utáni drasztikus intézkedések a fordított áfakulcsok és az áfakulcs csökkentések terén a mezőgazdaság és élelmiszeripar területén az áfacsalás csökkenésének irányába hatott.

\subsubsection{Az áfarés a gazdasági fejlettség kapcsolata}

Látható, hogy a vizsgált időszakban az áfarés területi alakulása nem volt kiegyensúlyozott, a megyék közti sorrend jelentősen átalakult (ahogy a 31-33. ábrákon bemutattam). A sorrendet többféle tényező is befolyásolhatta. Elsőként meg kell említeni a gazdasági fejlődés eltérő ütemét. A magasabb GDP, vagyis a gazdasági szereplők által 
megszerezhető elsődleges jövedelem szintje meghatározhatja, hogy a gazdasági szereplők kockázatkedvelők vagy kockázatkerülők.

Az eltérő áfarés alakulást az intézményi változások is okozhatják. Bár az adó és egyéb jogszabályok az ország teljes területén érvényesek, azonban a vállalkozások összetétele területi egységenként eltérö. Emiatt például az élelmiszeripart vagy mezőgazdasági termékek áfakulcsát érintő jogszabályváltozások abban a régióban gyakorolnak nagyobb hatást, ahol ezeknek a vállalkozásoknak a relatív gyakorisága nagyobb.

Végül érdemes kiemelni a régió specifikus tényezők hatását. Előfordulhat, hogy bizonyos magatartásformák bizonyos régiókban gyakoribbak. Amennyiben ez igaz, az a Hausman teszttel vizsgálható meg, a Hausman teszt null hipotézisének elutasításával támasztható alá.

A gazdasági fejlettséget az egy före jutó konstans áras GDP-vel lehet mérni. ${ }^{15}$ Az Eurostat honlapján a NUTS2 szintű GDP volumenindexek állnak rendelkezésre előző évhez viszonyítva a vizsgált időszakra. Emiatt az elemzést megyei szint helyett NUTS2 szinten végeztem el. A volumenindexek segítségével a folyó áras, NUTS2 szintü GDP adatokból kiszámítottam elsőként az előző évi áras GDP értéket:

$G D P_{i t}^{P Y P}=I_{i t}^{q} \cdot G D P_{i t-1}^{C U P}$

$\mathrm{Az} I_{i t}^{q}$ jelenti a volumenindexet az $i$ NUTS2 régióra, a $t$ évre, $G D P_{i t-1}^{C U P}$ jelenti a folyóáras GDP-t az $i$ régióra és a $t-1$ évre. GDP $P_{i t}^{P Y P}$ az előző évi áras GDP az $i$ régióra a $t$ évre. A következő lépésben kiszámítottam a 2005. évi áras GDP-t az előző évi áras adatok láncolásával.

$G D P_{i t}^{C O P}=G D P_{i t}^{P Y P} \frac{G D P_{i t-1}^{C O P}}{G D P_{i t-1}^{C U P}}$

A $G D P_{i t}^{C O P}$ jelenti a GDP értékét konstans áron az $i$ régióra és a $t$ évre. A 2005. évi árra számított GDP 2006-ban megegyezik a 2006-os előző évi áras értékével. A láncolás eljárását részletesen Anwar - Szőkéné Boros tanulmánya ismerteti. (Anwar \& Szőkéné Boros, 2008)

\footnotetext{
${ }^{15}$ A gazdasági fejlettség sokkal komplexebb, mint az egy före jutó GDP, azonban, mivel nem áll rendelkezésre területi szinten a jelenséget jobban lefedő indikátor, ezért mégis ezt alkalmazom.
} 
Az évközepi lakónépesség szintén rendelkezésre áll NUTS2 szinten. A GDP konstans áras értékeinek és az évközepi népesség hányadosából határoztam meg az egy főre jutó konstans áras GDP-t.

gdppercapita $_{i t}=\frac{G D P_{i t}^{C O P}}{\text { population }}$

Az előző képletben a population ${ }_{i t}$ mutatja meg az évközepi lakónépesség számát, a $g d p p e r c a p i t a_{i t}$ az egy főre jutó változatlan áras GDP az $i$ régióra és a $t$ évre.

A 8. táblázat a vizsgált időszakra kiszámított egy főre jutó konstans áras GDP értékekét mutatja be.

8. táblázat: Az egy före jutó GDP 2005. évi áron, $\mathrm{mFt}$

\begin{tabular}{|c|r|r|r|r|r|r|r|r|}
\hline Év & Budapest & Pest & $\begin{array}{c}\text { Közép- } \\
\text { Dunántúl }\end{array}$ & $\begin{array}{c}\text { Nyugat- } \\
\text { Dunántúl }\end{array}$ & $\begin{array}{c}\text { Dél- } \\
\text { Dunántúl }\end{array}$ & $\begin{array}{c}\text { Észak- } \\
\text { Magyarország }\end{array}$ & $\begin{array}{c}\text { Észak- } \\
\text { Alföld }\end{array}$ & $\begin{array}{c}\text { Dél- } \\
\text { Alföld }\end{array}$ \\
\hline $\mathbf{2 0 0 6}$ & 5,09 & 2,01 & 2,11 & 2,33 & 1,57 & 1,50 & 1,48 & 1,56 \\
\hline $\mathbf{2 0 0 7}$ & 5,03 & 2,20 & 2,23 & 2,32 & 1,54 & 1,49 & 1,46 & 1,51 \\
\hline $\mathbf{2 0 0 8}$ & 5,07 & 2,07 & 2,19 & 2,34 & 1,61 & 1,48 & 1,52 & 1,60 \\
\hline $\mathbf{2 0 0 9}$ & 4,89 & 1,91 & 1,84 & 2,09 & 1,53 & 1,33 & 1,46 & 1,50 \\
\hline $\mathbf{2 0 1 0}$ & 4,81 & 1,98 & 1,95 & 2,26 & 1,51 & 1,33 & 1,44 & 1,46 \\
\hline $\mathbf{2 0 1 1}$ & 4,82 & 1,92 & 2,05 & 2,38 & 1,54 & 1,37 & 1,50 & 1,52 \\
\hline $\mathbf{2 0 1 2}$ & 4,84 & 1,87 & 2,00 & 2,38 & 1,51 & 1,32 & 1,45 & 1,51 \\
\hline $\mathbf{2 0 1 3}$ & 4,92 & 1,94 & 2,08 & 2,41 & 1,58 & 1,38 & 1,48 & 1,59 \\
\hline $\mathbf{2 0 1 4}$ & 4,96 & 2,00 & 2,20 & 2,68 & 1,64 & 1,48 & 1,58 & 1,71 \\
\hline $\mathbf{2 0 1 5}$ & 5,03 & 2,10 & 2,34 & 2,83 & 1,66 & 1,61 & 1,62 & 1,79 \\
\hline $\mathbf{2 0 1 6}$ & 5,15 & 2,12 & 2,46 & 2,94 & 1,73 & 1,63 & 1,65 & 1,83 \\
\hline
\end{tabular}

Forrás: saját számítás

A panelmodellben megvizsgáltam, hogy az egy före jutó változatlan áras GDP magyarázza-e a NUTS2 szintü áfarés nagyságát.

$\operatorname{vatgap}_{i t}=a_{i}+b \cdot g d p p e r c a p i t a_{i t}+\varepsilon_{i t}$

Az alapmodellre elsőként a Hausman tesztet futtattam, annak érdekében, hogy a fixed vagy a random effect becslési eljárás közül a statisztikailag megalapozottat kiválasszam. A teszt eredménye az alapmodellre a 9. táblázatban látható. 
9. táblázat: A Hausman teszt eredménye

\begin{tabular}{|lr|r|r|r|}
\hline Null hipotézis & Tesztstatisztika $(\mathrm{H})$ & Szabadságfok & Probability \\
\hline $\begin{array}{l}\text { Keresztmetszeti } \\
\text { effect fennáll }\end{array}$ & 3,0503 & 1 & 0,0807 \\
\hline Forrás: saját eredmény & random & 3,0507 &
\end{tabular}

A Hausman teszt alapján a szokásos, 5\%-os szignifikancia szinten a null hipotézist el kellene fogadni, azonban 10\%-os szignifikancia szinten a $\mathrm{H} 0$ elutasítása lenne a megfelelő döntés. Az áfacsalás jellege miatt azonban indokoltabb a fixed effect modell alkalmazása. A következőkben a fixed effect modellt alkalmaztam.

Az alapmodell illesztésének statisztikái a következő ábrán láthatók. (A modell illesztését EViews-ban végeztem el.)

\section{4. ábra: Az alapmodell illesztésének eredménye}

\begin{tabular}{|c|c|c|c|c|}
\hline \multicolumn{5}{|c|}{$\begin{array}{l}\text { Dependent Variable: VAT GAP } \\
\text { Method: Panel Least Squares } \\
\text { Date: 02/05/20 Time: 13:28 } \\
\text { Sample: } 20062016 \\
\text { Periods included: } 11 \\
\text { Cross-sections included: } 8 \\
\text { Total panel (balanced) observations: } 88\end{array}$} \\
\hline Variable & Coefficient & Std. Error & t-Statistic & Prob. \\
\hline$\frac{\mathrm{C}}{\text { REALGDPPERCAPITA }}$ & $\begin{array}{r}0.352500 \\
-0.032212\end{array}$ & $\begin{array}{l}0.023417 \\
0.009497\end{array}$ & $\begin{array}{r}15.05337 \\
-3.391677\end{array}$ & $\begin{array}{l}0.0000 \\
0.0011\end{array}$ \\
\hline \multicolumn{5}{|c|}{ Effects Specification } \\
\hline \multicolumn{5}{|c|}{ Cross-section fixed (dummy variables) } \\
\hline $\begin{array}{l}\text { R-squared } \\
\text { Adjusted R-squared } \\
\text { S.E. of regression } \\
\text { Sum squared resid } \\
\text { Log likelihood } \\
\text { F-statistic } \\
\text { Prob(F-statistic) }\end{array}$ & $\begin{array}{l}0.605506 \\
0.565557 \\
0.096995 \\
0.743229 \\
85.19329 \\
15.15707 \\
0.000000\end{array}$ & $\begin{array}{l}\text { Mean depe } \\
\text { S.D. depen } \\
\text { Akaike info } \\
\text { Schwarz cri } \\
\text { Hannan-Qu } \\
\text { Durbin-Wat }\end{array}$ & $\begin{array}{l}\text { dent var } \\
\text { ent var } \\
\text { riterion } \\
\text { erion } \\
\text { on criter. } \\
\text { on stat }\end{array}$ & $\begin{array}{r}0.281240 \\
0.147157 \\
-1.731666 \\
-1.478302 \\
-1.629592 \\
0.970345\end{array}$ \\
\hline
\end{tabular}

\section{Forrás: saját eredmény}

A modellben az egy före jutó változatlan áras GDP koefficiense szignifikáns és negatív, értéke -0,03. Vagyis az egy före jutó változatlan áras GDP egy millió forintos emelkedése a NUTS2 szintű régiókban átlagosan 3 százalékponttal csökkenti a régió szintü áfarést minden egyéb változatlansága mellett. Az illesztett modell a teljes szórás 56,6\%-át magyarázza meg, tehát a közepesnél erősebb a kapcsolat a két változó között. 
Azonban a modell illeszkedése még nem megfelelö. Két területen lehet a modellt finomítani. Az egyik, hogy a vizsgált időszakban volt, 2008-2012 között a világgazdasági válság, ami Magyarországon hitelválsággal is együtt járt. Az ilyen időszakok, amikor a fogyasztás és a jövedelem jelentős mértékben csökken, és magas a munkanélküliség, jelentősebb motivációt jelenthet az áfacsalásra. Emiatt egy válság dummy-t alkalmaztam a 2008-2012 közötti évekre. Az alapmodell másik hibája, hogy a Durbin-Watson statisztika alapján az idősorban autokorreláció van jelen. Emiatt az áfarés egy időszakos késleltetett értékét alkalmaztam a modellben. A továbbfejlesztett modell a következő egyenlettel írható fel:

$\operatorname{vatgap}_{i t}=a_{i}+b \cdot$ gdppercapita $_{i t}+c \cdot$ dummy $_{2008-2012}+d \cdot \operatorname{vatgap}_{i-1}+\varepsilon_{i t}$

\section{5. ábra: A továbbfejlesztett modell diagnosztikái}

\begin{tabular}{|c|c|c|c|c|}
\hline \multicolumn{5}{|c|}{$\begin{array}{l}\text { Dependent Variable: VAT GAP } \\
\text { Method: Panel Least Squares } \\
\text { Date: } 02 / 05 / 20 \text { Time: } 13: 19 \\
\text { Sample (adjusted): } 20072016 \\
\text { Periods included: } 10 \\
\text { Cross-sections included: } 8 \\
\text { Total panel (balanced) observations: } 80\end{array}$} \\
\hline Variable & Coefficient & Std. Error & t-Statistic & Prob. \\
\hline $\begin{array}{c}\text { C } \\
\text { VALSAG DUMMY } \\
\text { REALGDPPERCAPITA } \\
\text { VAT GAP(-1) }\end{array}$ & $\begin{array}{r}0.206094 \\
0.139535 \\
-0.041491 \\
0.360009\end{array}$ & $\begin{array}{l}0.033207 \\
0.051100 \\
0.008324 \\
0.098383\end{array}$ & $\begin{array}{r}6.206280 \\
2.730636 \\
-4.984678 \\
3.659261\end{array}$ & $\begin{array}{l}0.0000 \\
0.0080 \\
0.0000 \\
0.0005\end{array}$ \\
\hline \multicolumn{5}{|c|}{ Effects Specification } \\
\hline \multicolumn{5}{|c|}{ Cross-section fixed (dummy variables) } \\
\hline $\begin{array}{l}\text { R-squared } \\
\text { Adjusted R-squared } \\
\text { S.E. of regression } \\
\text { Sum squared resid } \\
\text { Log likelihood } \\
\text { F-statistic } \\
\text { Prob(F-statistic) }\end{array}$ & $\begin{array}{l}0.738923 \\
0.701086 \\
0.076820 \\
0.407195 \\
97.70448 \\
19.52901 \\
0.000000\end{array}$ & $\begin{array}{l}\text { Mean depe } \\
\text { S.D. depen } \\
\text { Akaike info } \\
\text { Schwarz cri } \\
\text { Hannan-Qu } \\
\text { Durbin-Wat }\end{array}$ & $\begin{array}{l}\text { dent var } \\
\text { ent var } \\
\text { riterion } \\
\text { erion } \\
\text { nn criter. } \\
\text { on stat }\end{array}$ & $\begin{array}{r}0.278385 \\
0.140509 \\
-2.167612 \\
-1.840083 \\
-2.036296 \\
2.175448\end{array}$ \\
\hline
\end{tabular}

\section{Forrás: saját eredmény}

A továbbfejlesztett modell paramétereit vizsgálva a 35. ábra alapján látható, hogy a gazdasági válsággal járó bizonytalanság minden egyéb változatlansága mellett közel 14 százalékponttal növeli a területi áfarést. A változatlan áras egy főre jutó GDP és az áfarés közti kapcsolat negatív, a változatlan áras egy före jutó GDP egységnyi növekedése 4 százalékponttal csökkenti az áfarést. Végül az áfarés a saját korábbi értékétől függ. 
A továbbfejlesztett modellben az eredményváltozó szórásának 70\%-át magyarázza meg a felírt regressziós modell, ami a korábbi modellhez képest jelentős növekedés. Az információs kritériumok alapján is a továbbfejlesztett modell elfogadása megalapozott.

\subsubsection{5.Összefoglaló}

Az alfejezetben bemutattam az áfacsalás becslés eredményét. Az áfacsalást az áfaréssel validáltam. A becsült áfarés 2006-2011 között növekszik, 2012-től csökkenő tendencia bontakozik ki a kormányzati intézkedésekkel összhangban. A válság első éve, 2008 a becslésem szempontjából kiugró érték.

A fejezetben bemutatott modellek segítségével sikerült alátámasztani, hogy a gazdasági növekedés és az áfarés egymással fordított arányban áll. A gazdasági válság hatása Magyarországon szignifikáns az áfarés vonatkozásában. Számos statisztikai hivatal az adócsalás miatt nem megfigyelt hozzáadott érték becslésekor a számításokhoz normákat alkalmaz. Például a kibocsátás adott százaléka az adócsalás miatt nem megfigyelt hozzáadott érték. A feltárt összefüggés alapján az ilyen jellegü számítások hibás eredményre vezethetnek. Különösen fontosnak tartom, hogy a gazdasági válság okozta helyzet még a gazdaság csökkenésének hatásán felül is további áfarés növekedést okoz.

Amennyiben a statisztikai hivatalok nem térképezik fel ezeket az összefüggéseket, egy gazdasági válság esetén a valóságosnál jóval kedvezőtlenebb GDP alakulást mutathatnak ki.

Továbbá fontos eredmény, hogy az áfarést a saját korábbi értéke is meghatározza. Ez annak lehet a következménye, hogy az áfacsalás nem függetleníthető a tranzakciós hálózatoktól. A tranzakciókba való beépülése viszonylag tartós hatásokat eredményezhet.

\section{Az eredmények implementálása és a további kutatási lehetőségek}

Kutatásom elsődleges célja volt, hogy az áfacsalásra olyan részletes és jó minőségű becslést készítsek, amely a nemzeti számlák összeállításához megfelelő inputot jelent. Az általam elkészített becslés erre a célra megfelelő.

A megfelelően felépített becslés alapfeltétele az elméleti és empirikus folyamatok feltérképezése. Ennek érdekében áttekintettem az elméleti szakirodalmat. Ismertettem a szabályszegő magatartás elméleti keretrendszerét. Vizsgálataim alapján a reciprocitáson 
alapuló folyamatok döntően meghatározzák az együttműködés, a bizalom és a társadalmi tőke szintjét. Az intézményi környezet és a politikai rendszer szintén hatást gyakorol az együttműködésre. Ezek az attitüdök hosszú távú hatással bírnak a szabálykövető magatartásra, ezen belül az adócsalásra is.

Ezután bemutattam a különböző nem megfigyelt tevékenységeket a szocialista rendszerben, a rendszerváltás időszakában és az ezredforduló után. Ezek a tevékenységek közvetlenül nem, de a társadalmi tőkén keresztül még mindig hatást gyakorolnak a jelen szabályszegő magatartására és kormányzattal és a többi emberrel szemben kialakuló bizalmi szintre.

Ezt követően ismertettem a nem megfigyelt gazdaság becslésére rendelkezésre álló módszereket. Mivel a nemzeti számlák felhasználására készülő input adatról van szó, az aggregált, modell alapú becslések, ahol a tevékenységek köre nem kellően lehatárolható, nem jöhettek szóba. A mikroszintü, adminisztratív adatok lehetővé teszik a megfelelő részletezettségü, és a körülmények változására érzékenyen reagáló becslési eljárás alkalmazását. Ezért esett a választásom a nem paraméteres gépi tanulásos eljárásokra.

A nemzeti számlák összeállítása során a GDP termelési oldali becslésében ki kell mutatni az adócsalás miatt nem megfigyelt hozzáadott értéket, és a bünrészesség nélküli áfacsalás nagyságát is. Az adócsalás miatt nem megfigyelt hozzáadott érték és az áfacsalás kapcsolata még további vizsgálatokat igényel, azonban valószínűsíthető, hogy az általam kiszámított áfacsalás a hozzáadott érték becsléséhez jó kiindulópontot nyújthat. A jövőben szeretném az áfacsalás becslést folytatni, ameddig az adóellenőrzés minta ezt megfelelő minőségben lehetővé teszi.

Az áfacsalás az Európai Unióban jellemzően a közösségen belüli kereskedelmet érintő csalási tevékenységet érinti. Terveim szerint az áfacsalás becslés áfacsalás típusok szerinti megbontása a következő nagyszabású kutatási területem. 


\section{Irodalomjegyzék}

1. Ádám, G. (1986). Az orvosi hálapénz Magyarországon. Budapest: Magvető Kiadó.

2. ado.hu. (2020. január 8). Forrás: Ado.hu: www.ado.hu

3. Ahumada, H., Alvaredo, F., \& Canavese, A. J. (2006). The Demand for Currency Approach and the Size of the Shadow Economy: A Critical Assessment. Berkeley Program in Law and Economics, Working Paper Series; https://escholarship.org/uc/item/6zn9p98b.

4. Akerlof, G. (1970). The Market for "Lemons": Quality Uncertainty and the Market mechanism. The Quarterly Journal of Economics 84/3, 488-500.

5. Akerlof, G. A., \& Shiller, R. J. (2009). Animal Spirits. Princeton and Oxford: Princeton University Press. Letöltés dátuma: 2020. december 22 , forrás: https://altexploit.files.wordpress.com/2017/06/shiller-robert-j-_-akerlof-george-a-animal-spirits_-how-human-psychology-drives-the-economy-and-why-it-matters-for-global-capitalism-newedition-princeton-university-press-201020.pdf

6. Állami Számvevőszék. (2019). Elemzés. Budapest: Állami Számvevőszék.

7. Allingham, M. G., \& Sandmo, A. (1972). Income Tax Evasion: a Theoretical Analysis. Journal of Public Economics 1, 323-338.

8. Alstadsæter, A., Johannesen, N., \& Zucman, G. (2017. szeptember). NBER WORKING PAPER SERIES. Letöltés dátuma: 2021. január 21, forrás: Tax evasion and inquality: https://www.nber.org/system/files/working_papers/w23772/w23772.pdf

9. Anwar, K., \& Szőkéné Boros, Z. (2008). A láncindexek alkalmazása a nemzeti számlákban. Statisztikai Szemle, 86. évfolyam 7-8. szám, 713-731. Letöltés dátuma: 2020.. február 5., forrás: http://www.ksh.hu/statszemle_archive/all/2008/2008_07-08/2008_07-08_713.pdf

10. Ariely, D. (2015). Az (őszinte) igazság a hazugságról. Hogyan csapjuk be önmagunkat és másokat? Budapest: HVG Kiadó.

11. Artavansi, N., Morse, A., \& Tsoutsoura, M. (2015. szeptember). Tax evasion across industries: soft credit evidence from Greece. Letöltés dátuma: 2021. január 21, forrás: NBER WORKING PAPER SERIES: https://www.nber.org/system/files/working_papers/w21552/w21552.pdf

12. Árvay, J., \& Vértes, A. (1997/7). A magánszektor és a rejtett gazdaság súlya Magyarországon. Statisztikai Szemle, 517-529.

13. Árvay, J., \& Vértes, A. (2006). A magángazdaság. Forrás: TÁRKI: http://old.tarki.hu/adatbankh/kutjel/pdf/a912.pdf

14. Balog, Á. (2014). Adóelkerülés és rejtett gazdaság Magyarországon. Köz-Gazdaság, 15-30.

15. Becker, A. (2017. május 24). Kishalak a hálóban: erre jutott a nyomozás egy több százmilliós áfacsalás ügyében. Forrás: atlatszo.hu: https://atlatszo.hu/2017/05/24/kishalak-a-haloban-errejutott-a-nyomozas-egy-tobb-szazmillios-afacsalas-ugyeben/

16. Becker, G. (1974). Crime and punishment. In G. Becker, \& W. Landes, Essays in the Economics of Crime and Punishment (old.: 1-54). New York: Columbia University Press.

17. Belyó, P. (2003). A rejtett gazdaság lakossági megítélése. Statisztikai Szemle vol. 81 number 7 , 521-541.

18. Belyó, P. (2004). A vállalkozások és a rejtett gazdaság. Statisztikai Szemle vol. 82 number 1, $44-$ 66.

19. Belyó, P. (2008). A rejtett gazdaság természetrajza. Budapest: SALDO Könyvkiadó.

20. Benke, G., \& Karcagi-Kováts, A. (2017). Szándék és valóság - egy attitűdvizsgálat eredményei a rejtett gazdaságról. Taylor, gazdálkodás- és szervezéstudományi folyóirat, 116-125. Letöltés 
dátuma: 2021. január 31, forrás: http://acta.bibl.u-szeged.hu/55005/1/taylor_2017_003_004_116125.pdf

21. Benzarti, Y., Carloni, D., Harju, J., \& Kosonen, T. (2018. november). What goes up may not come down: asymmetric incidence of value-added taxes. Letöltés dátuma: 2021. január 25, forrás: NBER Working paper series: https://www.nber.org/system/files/working_papers/w23849/w23849.pdf

22. Bereczkei, T. (2009). Az erény terméeszete Önzetlenség, együttmüködés, nagylelküség. Budapest: Typotex.

23. Bezsenyi, T. (2015). Megszervezett bizonytalanság avagy a szervezett bünözés mint a szocialista kori nyilvánosság tabuja. Metszetek, Vol. 4 No. 1, 36-55.

24. Bezsenyi, T. (2020. január 13.). A szervezett bünözés átalakuló tevékenységei a rendszerváltás kori Magyarországon . Forrás: Biztonságpolitika: https://biztonsagpolitika.hu/wpcontent/uploads/2016/06/Bezsenyi_Tamas_A_szervezett_bunozes_atalakulo_tevekenysegei_a_r endszervaltas_kori_Magyarorszagon.pdf

25. Bhattacharyya, D. K. (1999). On the Economic Rationale of Estimating the Hidden Economy. The Economic Journal, Vol. 109, No. 456, 348-359.

26. Bogdanov, D., Jõemets, M., Siim, S., \& Vaht, M. (2015. január). How the Estonian Tax and Customs Board Evaluated a Tax Fraud Detection System Based on Secure Multi-party Computation. Letöltés dátuma: 2021. január 21, forrás: International Conference on Financial Cryptography and Data Security: https://www.ifca.ai/pub/fc15/89750209.pdf

27. Borselly, F. (2011. október). Organised VAT fraud: features, magnitude, policy perspectives. Letöltés dátuma: 2021. január 21, forrás: Banca D'Italia Eurosistema: https://www.bancaditalia.it/pubblicazioni/qef/2011-0106/QEF_106.pdf

28. Bowles, S. (2018). Az etikus gazdaság. Miért nem helyettesithetik a jó ösztönzök a jó állampolgárokat. Budapest: Pallas Athéné Könyvkiadó Kft.

29. Böröcz, J. (2000). Kistársadalom - kiskapuk. Letöltés dátuma: 2020. február 12, forrás: http://magyar-irodalom.elte.hu/2000/uj/01.htm.

30. Breusch, T. (2005). Estimating the Underground Economy using MIMIC Models. Canberra: The Australian National University .

31. Chen, J., \& Shao, J. (2000). Nearest Neighbor Imputation for Survey Data. Journal of Official Statistics 16. évf 2. sz., 113-131. Letöltés dátuma: 2019.. október 9., forrás: https://www.istat.it/it/files/2014/05/JOS-162-113-131.pdf

32. Ciaburro, G., \& Venkateswaran, B. (2017). Neural Networks with R. Birmingham: Packt Publishing Ltd. Forrás: https://edu.kpfu.ru/pluginfile.php/419285/mod_resource/content/2/neural-networks-r.pdf

33. Czakó, Á. (1997). Négy város négy piaca. A népi kereskedéstől a kgst-piacokig. Közgazdasági Szemle XLIV. évf. április, 339-355.

34. Cserháti, I., Dobszayné Hennel, J., Keresztély, T., Péter, Á. I., Takács, T., \& Varga, Z. (2009). A rejtett gazdaság mérése és visszaszoritásának lehetöségei. Budapest: ECOSTAT.

35. Dobsi, V. (2018. február 5). vilagterkep.atlatszo.hu. Forrás: Itt az adóparadicsomok listája: az élen Svájc, az USA és a Kajmán-szigetek: https://vilagterkep.atlatszo.hu/2018/02/05/itt-azadoparadicsomok-listaja-az-elen-svajc-az-usa-es-a-kajman-szigetek/

36. Ékes, I. (1993). Rejtett gazdaság - láthatatlan jövedelmek tegnap és ma. Budapest: Ékes Ildikó.

37. Ékes, I. (1997. január). Adózás, 1988-1996. Statisztikai szemle, 45-57. Letöltés dátuma: 2021. január 26, forrás: http://www.ksh.hu/statszemle_archive/1997/1997_01/1997_01_045.pdf

38. Elek, P., Scharle, Á., Szabó, B., \& Szabó, P. A. (2009). A feketefoglalkoztatás mértéke Magyarországon. In A. Semjén, \& I. J. Tóth, Rejtett Gazdaság. Be nem jelentett foglalkoztatás és jövedelemeltitkolás - kormányzati lépések és a gazdasági szereplök válaszai (old.: 84-103). Budapest: MTA Közgazdaságtudományi Intézet. 
39. Európai Bizottság. (2012). Report to the Study to quantify and analyse the VAT Gap in the EU-27 Member States. Letöltés dátuma: 2019. október 15, forrás: https://ec.europa.eu/taxation_customs/sites/taxation/files/resources/documents/common/publicati ons/studies/vat_gap2012.pdf

40. Európai Bizottság. (2013). Study to quantify and analyse the VAT Gap in the EU-27 Member States Final Report. Letöltés dátuma: 2019. október 15, forrás: https://ec.europa.eu/taxation_customs/sites/taxation/files/docs/body/vat-gap.pdf

41. Európai Bizottság. (2014). Special Eurobarometer 397, Corruption, Report. Forrás: https://ec.europa.eu/commfrontoffice/publicopinion/archives/ebs/ebs_397_en.pdf

42. Európai Bizottság. (2014). Study to quantify and analyse the VAT Gap in the EU-27 Member States Final Report. Letöltés dátuma: 2019. október 15, forrás: https://ec.europa.eu/taxation_customs/sites/taxation/files/2016-09_vat-gap-report_final.pdf

43. Európai Bizottság. (2015). Study to quantify and analyse the VAT Gap in the EU-27 Member States Final Report. Letöltés dátuma: 2019. október 15, forrás: https://ec.europa.eu/taxation_customs/sites/taxation/files/docs/body/vat_gap2013.pdf

44. Európai Bizottság. (2016). Study and Reports on the VAT Gap in the EU-28 Member States: 2016 Final Report. Letöltés dátuma: 2019. október 15, forrás: https://ec.europa.eu/taxation_customs/sites/taxation/files/2016-09_vat-gap-report_final.pdf

45. Európai Bizottság. (2017). Study and Reports on the VAT Gap in the EU-28 Member States: 2017 Final Report. Letöltés dátuma: 2019. október 15, forrás: https://papers.ssrn.com/sol3/papers.cfm?abstract_id=3064726\&download=yes

46. Európai Bizottság. (2018). Study and Reports on the VAT Gap in the EU-28 Member States: 2018 Final Report. Letöltés dátuma: 2019. október 15, forrás: https://ec.europa.eu/taxation_customs/sites/taxation/files/2018_vat_gap_report_en.pdf

47. Európai Bizottság. (2019). Study and Reports on the VAT Gap in the EU-28 Member States: 2019 Final Report. Letöltés dátuma: 2019. október 15, forrás: https://ec.europa.eu/taxation_customs/sites/taxation/files/vat-gap-full-report-2019_en.pdf

48. Eurostat. (2005). Eurostat's Tabular Approach to Exhaustiveness. Guidelines. Luxembourg: Eurostat.

49. Fanelli, A., Ahmad, N., \& Pinto, R. (2004. december). The Informal Economy in Albania. Letöltés dátuma: 2021. január 26, forrás: Researchgate.net: https://www.researchgate.net/publication/282733678_The_Informal_Economy_in_Albania_anal ysis_and_policy_recommendations/download

50. Fazekas, M. (2009). A rejtett gazdaságból való kilépés dilemmái. Esettanulmány - budapesti futárszolgálatok, 2006-2008. In A. Semjén, \& I. J. Tóth, Rejtett gazdaság. Be nem jelentett foglalkoztatás és jövedelemeltitkolás - kormányzati lépések és a gazdasági szereplök válaszai (old.: 184-200). Budapest: MTA Közgazdaságtudományi Intézet.

51. Fenyvesi, É., \& Vágány, J. B. (2020. május). A rejtett gazdaság néhány területének szisztematikus szakirodalmi áttekintése. Közgazdasági szemle, 512-532. Letöltés dátuma: 2021. január 30, forrás: http://real.mtak.hu/108654/1/05FenyvesiVaganyA.pdf

52. Fix, E., \& Hodge, J. L. (1951). Discriminatory Analysis Nonparametric Discrimination: Consistency Properties. Central Air Documents Office. USAF School of Aviation Medicine Rnadolph Field. Texas. Letöltés dátuma: 2019. . október 9, forrás: https://apps.dtic.mil/dtic/tr/fulltext/u2/a800276.pdf

53. Frey, B. S., \& Pommerehne, W. W. (1984). The hidden economy: State and prospects for measurement. Review of Income and Wealth 30:, 1-23.

54. Frey, B. S., \& Weck-Hannemann, H. (1984). The Hidden Economy as an 'Unobserved' variable. European Economic Review 26, 33-53.

55. Frunza, M.-C. (2020. február 3). Cost of the MTIC VAT fraud for European Union members. Letöltés dátuma: 2021. január 21, forrás: http://www.schwarzthal.com/VATEU.pdf

56. Fukuyama, F. (2007). Bizalom. Budapest: Európa Könyvkiadó. 
57. Gábor, R. I., \& Galasi, P. (1981). A „második” gazdaság. Budapest: Közgazdasági és Jogi Könyvkiadó.

58. Giles, D. E. (1999). Measuring the Hidden Economy: Implications for Econometric Modelling. The Economic Journal Vol. 109, No. 456, 370-380.

59. Gradeva, K. (2014. Augusztus 7). VAT fraud in Intra-EU Trade. Letöltés dátuma: 2021. január 21, forrás: https://www.etsg.org/ETSG2014/Papers/378.pdf

60. Grossman, G. (1977). The "Secons Economy" of the USSR. Problems of Communism 1977/9. szám, 25-40. Forrás: https://www.unz.com/print/ProblemsCommunism-1977sep-00025/

61. Hajdu, O. (2003). Többváltozós statisztikai számítások. Budapest: Központi Statisztikai Hivatal.

62. Hámori, B. (2003). Kísérletek és kilátások Daniel Kahneman. Közgazdasági Szemle L. évf szeptember, 779-799.

63. Han, J., \& Kamber, M. (2004). Adatbányászat Koncepciók és technikák. Budapest: Panem Kiadó.

64. Hasseldine, D. J., \& Bebbington, K. J. (1991). Blending economic deterrence and fiscal psychology models in the design of responses to tax evasion. The New Zealand experience . Journal of Economic Psychology Volume 12, 299-324.

65. https://fairtaxmark.net/. (2020). Forrás: https://fairtaxmark.net/

66. Hunyadi, L., \& Vita, L. (2008). Statisztika I. Budapest: Aula Kiadó.

67. hvg.hu. (2009. november 11). Magyar cégek GDP szerinti rangsora: a nagyok jobban birják a gyürödést. Letöltés dátuma: 2020. március 7, forrás: HVG.HU: https://hvg.hu/gazdasag/20091111_ecostat_top-100_gdp_ranglista

68. hvg.hu. (2016. június 16). Forrás: Kiderült, mi áll a írországi GDP elképesztő megugrása mögött: https://hvg.hu/gazdasag/20160713_irorszag_gdp

69. hvg.hu. (2017. január 18). HVG. Forrás: Ma bezárták az állami pénzmosodát, de így is tisztára moshatja feketén szerzett vagyonát: http://hvg.hu/gazdasag/20170118_stabilitas_szamlak_vege_fekete_penzek

70. hvg.hu. (2017.. január 18.). Ma bezárták az állami pénzmosodát, de így is tisztára moshatja feketén szerzett vagyonát. Forrás: hvg.hu: https://hvg.hu/gazdasag/20170118_stabilitas_szamlak_vege_fekete_penzek

71. INSEE. (2016). ESA 2010 GNI Inventory - France. Forrás https://www.google.hu/url?sa=t\&rct=j\&q=\&esrc=s\&source=web\&cd=1\&ved=2ahUKEwicv7X SxIfnAhVhmYsKHa77COQQFjAAegQIBhAB\&url=https\%3A\%2F\%2Fwww.insee.fr\%2Fen\%2 Fmetadonnees\%2Fsource\%2Ffichier\%2FFrance_GNI_inventory.pdf\&usg=AOvVaw0Up2o2qtq 7DnUydNNM3KJR

72. James, K. (2011). Exploring the Origins and Global Rise of VAT. Letöltés dátuma: 2021. január 26, forrás: www.taxhistory.org: http://www.taxhistory.org/www/freefiles.nsf/422efdb8b12550d585256cfa00812512/308f39bfcb 20ced785257831006bcd0c/\$FILE/JAMES-2.pdf

73. Jöreskog, K. (1969). A general approach to confirmatory maximum likelihood factor analysis. Psychometrika, 183-202.

74. Kahneman, D. (2013). Gyors és lassú gondolkodás. Budapest: HVG Kiadó.

75. Kahneman, D., \& Tversky, A. (1979). Prospect Theory: An Analysis of Decision under Risk. Econometrica 47/2, 263-292.

76. Keen, M., \& Smith, S. (2007. február 21). VAT Fraud and Evasion: What Do We Know, and What Can be Done? Letöltés dátuma: 2021. január 23., forrás: IMF Working Paper: https://papers.ssrn.com/sol3/papers.cfm?abstract_id=964339

77. Kolosi, T. (1984). Státusz és Réteg Mühelytanulmány. Budapest: Társadalomtudományi Intézet.

78. Kolosi, T. (1987). Tagolt társadalom. Budapest: Gondolat Kiadó.

79. Kolosi, T., \& Szelényi, I. (2012). Hogyan legyünk milliárdosok. Budapest: Corvina. 
80. Kornai, J. (1989). Indulatos röpirat a gazdasági átmenet ügyében. Budapest: HVG Rt.

81. Kornai, J. (1999. július-augusztus). A rendszerparadigma. Közgazdasági Szemle, XLVI. évf., 585599.

82. Krekó, J., \& P. Kiss, G. (2007. szeptember 12). Adóelkerülés és a magyar adórendszer. $M N B$ tanulmányok 65. Letöltés dátuma: 2021. január 30, forrás: https://www.mnb.hu/letoltes/mt-65.pdf

83. Kruskal, W. H., \& Wallis, W. A. (1952). Use of Ranks in One-Criterion Variance Analysis. Journal of teh American Statistical Association Vol. 47, No. 260, 583-621. doi:10.1080/01621459.1952.10483441

84. KSH. (2006). Bruttó hazai termék 2005 (elözetes adatok II.) 2006 október.

85. KSH. (2010). MAGYARORSZÁG 1989-2009 A változások tükrében . https://www.ksh.hu/docs/hun/xftp/idoszaki/mo/mo1989_2009.pdf .

86. KSH. (2011). GNI Inventory of Hungary. Forrás: ksh.hu: http://www.ksh.hu/docs/eng/xftp/modsz/gni_inventory_ver_2_2.pdf?lang=hu

87. KSH(a). (2020. február 16.). Vállalkozások éves teljesítménymutatói. Forrás: KSH.hu: http://www.ksh.hu/apps/meta.objektum?p_lang=HU\&p_menu_id=110\&p_ot_id=100\&p_obj_id =BCBA\&p_session_id=29854484

88. KSH(b). (2020. február 17.). A gazdasági szervezetek gazdálkodási forma szerinti osztályozása. Forrás: KSH.HU: http:/www.ksh.hu/docs/osztalyozasok/gfo/gfo_rovid_leiras.pdf?lang=hu

89. KSH(c). (2020. február 17). Gazdasági tevékenységek egységes ágazati osztályozási rendszere, 2008. Forrás: KSH.HU: http://www.ksh.hu/docs/osztalyozasok/teaor/teaor_rovid_leiras.pdf

90. KSH(d). (2020. január 8). Stadat táblák. Forrás: ksh.hu.

91. Lackó, M. (2000). Egy rázós szektor: a rejtett gazdaság és hatásai a poszt-szocialista országokban háztartási áramfelhasználásra épülö becslések alapján. Budapest: MTA KTI, TÁRKI Társadalomkutatási Intézet.

92. Mandeville, B. (2004). A méhek meséje avagy magánvétkek - közhaszon. Budapest: Helikon Kiadó.

93. Marx, K. (1978). A töke. A politikai gazdaságtan bírálata. Elsö kötet I. könyv A töke termelési folyamata. Budapest: Kossuth Könyvkiadó.

94. Mas-Collel, A., \& Whinston, M. D. (1995). Microeconomic Theory. New York, Oxford: Oxford University Press.

95. Mauss, M. (2000). Tanulmány az ajándékról az ajándékcsere formája és értelme az archaikus társadalmakban. In M. Mauss, Szociológia és antropológia (old.: 195-343). Budapest: Osiris Kiadó.

96. Mazar, N., Amir, O., \& Ariely, D. (2008). The Dishonesty of Honest People: A Theory of SelfConcept Maintenance. Journal of Maarketing Research Volume 45 No. 6, 633-644.

97. Medina, L., \& Schneider, F. (2017). Shadow Economies Around the World: What Did We Learn Over the Last 20 Years? . https://www.imf.org/en/Publications/WP/Issues/2018/01/25/ShadowEconomies-Around-the-World-What-Did-We-Learn-Over-the-Last-20-Years-45583: IMF.

98. MTI. (1989. november 11). MDF-programok a vidék felemelkedéséért (1.rész). Letöltés dátuma: 2020. március 7, forrás: https://rendszervaltas.mti.hu/Pages/News.aspx ?se=1\&wo=\%22MDFprogramok+a+vid\%c3\%a9k+felemelked\%c3\%a9s\%c3\%a9\%c3\%a9rt\%22\&sd=19890101\&ed=1 9901231\&sp=0\&ni=213986\&ty=1

99. Murai, B. (2011). Az éves GDP-számítások keretrendszere. Statisztikai Szemle 89. évf. 6. szám, 609-623.

100.Murai, B., \& Ritzlné Kazimir, I. (2011). A nem megfigyelt gazdaság mérésének lehetőségei. Statisztikai Szemle Vol. 89. Num. 5, 501-522.

101.National Statistics Office - Malta. (2015. december). Gross National Income Inventory Malta. Forrás: 
https://nso.gov.mt/en/nso/Sources_and_Methods/Unit_A1/National_Accounts/Documents/GNI_ Inventory.pdf

102.NAV. (2015). Ellenőrzési irányok. Letöltés dátuma: 2019. október 7, forrás: http://drvilmanyi.eu/wp-content/uploads/2016/05/NAV-ellen\%C5\%91rz\%C3\%A9siir\%C3\%A1nyok-2015.pdf

103.NAV. (2016). A Nemzeti Adó- és Vámhivatal által kiadott 4001/2016. tájékoztatás az állami adóés vámhatóság 2016. évi ellenőrzési feladatainak végrehajtásához kapcsolódó ellenörzési irányokról.

104.NAV. (2019). A Nemzeti Adó- és Vámhivatal 2019-re szóló ellenőrzési terve, valamint a jogkövetést segitö eljárások fö téma- és célcsoportjai. Forrás: https://www.nav.gov.hu/nav/szabalyzok/tajekoztatasok/NAV_2019_ellenorzesi_terv.html

105.OECD. (2002). Measuring the Non-Observed Economy - A Handbook. Paris: OECD.

106. Official Journal of the European Union. (2013). Regulation (EU) NO 549/2013 of the European Parliament and of the Council of 21 May 2013 on the European system of national and regional accounts in the European Union (ESA 2010 is the anney of the regulation.). Forrás: https://eurlex.europa.eu/legal-content/EN/TXT/PDF/?uri=CELEX:32013R0549\&from=EN

107.Pénzügysziget. (2020. január 7). Forrás: https://penzugysziget.hu

108.Polányi, K. (1976). A gazdaság mint intézményesített folyamat 1957. In P. Károly, Archaikus társadalom és a gazdasági szemlélet. Budapest: Gondolat Kiadó.

109.Polányi, K. (2004). A nagy átalakulás - Korunk gazdasági és politikai gyökerei. Budapest: Napvilág Kiadó.

110.Reckon. (2009. Szeptember 9). Study to quantify and analyse the VAT gap in the EU-25 Member States.

Forrás: https://ec.europa.eu/taxation_customs/sites/taxation/files/docs/body/reckon_report_sep2009.pdf

111.Rév, I. (1996). Az atomizáció előnyei. Replika 23-24, 141-158.

112.Ritzlné Kazimir, I. (2014). The Estimation of Gross Value Added of Sole Proprietors for 2011 in Hungary. Hungarian Statistical Review, Special Number 18, 89-109.

113. Ritzlné Kazimir, I. (2017). Az adóelkerülés elmélete Köz-Gazdaság 12. évf. 4. szám. KözGazdaság Vol. 12. Num. 4., 257-268.

114.Ritzlné Kazimir, I. (2018). Is the Hungarian Non-Observed Economy Rooted in Socialism? IARIW, 35th General Conference. Copenhagen. Forrás: http://www.iariw.org/copenhagen/poster/ildiko.pdf

115.Ritzlné Kazimir, I., \& Máténé Bella, K. (2020). A gazdasági és a szabályozási környezet változásának hatása az áfaelkerülés 2006 és 2016 közötti alakulására Magyarországon. Statisztikai Szemle, 98. évfolyam 2. szám, 107-132. doi:10.20311/stat2020.2.hu0107

116. Sárközy, T. (1996). Lehetőség a sajátos magyar eredeti tőkefelhalmozás lezárására. Mozgó világ, 8, 3-11.

117.Schneider, F. (2002. July 23.11.2009 11:38). Size and Measurement of the Informal Economy in 110 Countries around the World. Forrás: http://www.amnet.co.il/attachments/informal_economy110.pdf

118.Scott, J. C. (1996 (a)). Az ellenállás hétköznapi formái. Replika 23-24, 109-130.

119.Scott, J. C. (1996 (b)). Erős-e a hamis tudat? Replika 23-24, 81-108.

120.Semjén, A., \& Tóth, I. J. (2009). Intézményi környezet, szerződéses fegyelem és adózási magatartás. In A. Semjén, \& I. J. Tóth, Rejtett gazdaság. Be nem jelentett foglalkoztatás és jövedelemeltitkolás - kormányzati lépések és a gazdasági szereplők v. Budapest: KTI Könyvek 11. MTA Közgazdaságtudományi Intézet .

121.Shahini, L., \& Malaj, A. (2015). How can We Measure the VAT Fraud and Evasion? Case of Albania. European Journal of Economics and Business Studies, May-August 2015, 40-49. Letöltés dátuma: 2021. január 23, forrás: http://journals.euser.org/files/articles/ejes_may_aug15/Ledjon.pdf 
122.Sik, E. (1996). Egy ló-öszvér a lovakról és a szamarakról. Közgazdasági Szemle XLIII. évf. júliusaugusztus, 704-725.

123.Sik, E. (1997). A kgst-piachely a mai Magyarországon. Közgazdasági Szemle, XLIV. évf, 322-338.

124.Sik, E. (2012). A kapcsolati tőke szociológiája. Budapest: Eötvös Kiadó. Forrás: http://old.tarki.hu/hu/about/staff/sb/kapcsolati_toke_szociologiaja.pdf

125.Sokolovska, O. (2016. április 7). Cross-border VAT frauds and measures to tackle them. Letöltés dátuma: 2021. január 21, forrás: https://mpra.ub.unimuenchen.de/70504/1/MPRA_paper_70504.pdf

126.STATEC. (2016. Június). Overview of the system of national accounts (Chapter 1 of the ESA 2010 GNI Inventory) Luxembourg. Forrás: https://www.google.hu/url?sa=t\&rct=j\&q=\&esrc=s\&source=web\&cd=2\&ved=2ahUKEwiIvsy_ yIfnAhXDxcQBHcc4BZoQFjABegQIBBAB\&url=https\%3A\%2F\%2Fcircabc.europa.eu\%2Fwe bdav\%2FCircaBC\%2FESTAT\%2FGNI\%2520OR\%2FLibrary\%2FESA\%25202010\%2520GNI $\% 2520$ Inventories\%2520-\%2520Chapter

127.Statistics Finland. (2016. május). ESA 2010 GNI Inventory. Forrás: https://www.stat.fi/til/vtp/vtp_2015_2016-06-02_men_001_en.pdf

128.Statistics Sweden. (2016. Október). Sweden GNI Inventory. Forrás: https://www.scb.se/contentassets/c89bb85e14184e92a4d5e4eec5ce4b98/sweden-gni-inventory2016_public_rev_oct2016.pdf

129.Statistische Bundesamt. (2016). German National Accounts, Domestic product and national income in accordance with ESA 2010 Methods and sources. Forrás: https://circabc.europa.eu/webdav/CircaBC/ESTAT/GNI\%20OR/Library/ESA\%202010\%20GNI \%20Inventories\%20-\%20public\%20versions/Germany/2015-2016/GNI_Inventory_Germany.pdf

130.Statistics Canada. (2018. december 12). Survey of Household Spending Technical Note. Letöltés dátuma: 2019 r október $\quad 9$, forrás: https://www150.statcan.gc.ca/n1/pub/62f0026m/62f0026m2018002-eng.htm

131.Sugár, A., \& Trautmann, L. (1995. január 1). A rejtélyes szektro - a második, az informális és a rejtett gazdaság természetéröl. Ezsmélet. Letöltés dátuma: 2021. január 30, forrás: https://www.eszmelet.hu/trautmann_laszlo-a-rejtelyes-szektor-a-masodik-az-informa/

132.Szabó, A., Gulyás, L., \& Tóth, I. J. (2009). Az adócsalás elterjedtségének változása - becslések a TAXSIM ágensalapú adócsalás-szimulátor segítségével. In A. Semjén, \& I. J. Tóth, Rejtett gazdaság. Be nem jelentett foglalkoztatás és jövedelemeltitkolás - kormányzati lépések és a gazdasági szereplők válaszai (old.: 65-84). Budapest: MTA Közgazdaságtudományi Intézet.

133.Szántó, Z., \& Tóth, I. J. (2001). A rejtett gazdaság és az ellene való fellépés tényezői. Közgazdasági Szemle, XLVIII. évf. március, 203-218.

134.Szücs, J. (2013). Az ingó vagyontárgyak értékesítésével összefüggő adókötelezettség. ado/online, old.: adó/online, http://ado.hu/szaklap/ado-lap/2013-7-8/az-ingo-vagyontargyak-ertekesitesevelosszefuggo-adokotelezettseg.

135.Tabandeh, R., \& Jusoh, M. (2012. június 6). Prosiding Perkem. Letöltés dátuma: 2021. január 21, forrás: Estimating Factors Affecting Tax Evasion in Malaysia: A Neural Network Method Analysis:

https://d1wqtxts1xzle7.cloudfront.net/30933605/PKEM2012_5D4.pdf?1363198976=\&responsecontent-

disposition=inline\%3B+filename\%3DEstimating_Factors_Affecting_Tax_Evasion.pdf\&Expires $=1611333424 \&$ Signature $=$ cMAiorqz-ncUfyU88e7pefV-

bEsILY9dFwFSP 7Xg1fvTeMMxmYd4jb

136. Tait, A. A. (1988). Value Added Tax International Practice and Problems. Washington, D. C.: International Monetary Fund. Letöltés dátuma: 2021. január 26, forrás: https://www.elibrary.imf.org/doc/IMF071/07773-9781557750129/077739781557750129/Other_formats/Source_PDF/07773-9781455265831.pdf

137.Tanzi, V. (1980). The Underground Economy in the United States: Estimates and Implication. Banca Nazionale del Lavoro 135:4, 427-453. 
138.Tedds, L. M. (2007. július). MPRA. Letöltés dátuma: 2021. január 21, forrás: Keeping it off the Books: And Empirical Investigation of Firms that Engage in Tax Evasion: https://mpra.ub.unimuenchen.de/39785/1/MPRA_paper_39785.pdf

139.Tóth, B. (2019). Elektronikus ügyintézés, elektronikus szolgáltatások, elektronikus tárhelyek. Adóvilág 2019. január XXIII. évf. 1. szám, 4-11.

140.Tóth, I. G. (2009). Bizalomhiány, normazavarok, igazságtalanságérzet és paternalizmus a magyar társadalom értékszerkezetében. Budapest: TÁRKI. Letöltés dátuma: 2020. december 22., forrás: https://www.tarki.hu/hu/research/gazdkult/gazdkult_elemzeszaro_toth.pdf

141. Vanoli, A. (2005). A History of National Accounting. Amsterdam: IOS Press.

142.VG.hu. (2013.. október 9.). Adóamnesztia a Stabilitási Megtakarítási Számla? Forrás: Világgazdaság: https://www.vg.hu/gazdasag/adoamnesztia-a-stabilitasi-megtakaritasi-szamla413388/

143. Von Neumann, J., \& Morgenstern, O. (1944). Theory of Games and Economic Behavior. Pricenton: Princeton University Press.

144.Weber, M. (1995). A protestáns etika és a kapitalizmus szelleme . Budapest: Cserépfalvy Kiadó.

145. White, J. C., Tompaiski, P., Vastaranta, M., \& Wulder, M. (2017. december). A model development and application guide for generating an enhanced forest inventory using airborne laser scanning data and an area-based approach. Letöltés dátuma: 2020. január 27., forrás: https://www.researchgate.net/profile/Joanne_White2/publication/323166566_A_model_develop ment_and_application_guide_for_generating_an_enhanced_forest_inventory_using_airborne_la ser_scanning_data_and_an_area-based_approach/links/5a83c50245851504fb3a78df/A-m

146. Williams, C. C. (2004). Cash-in-Hand Work The Underground Sector and The Hidden Economy of Favours. London: Palgrave Macmillan.

147.Wooldridge, J. M. (2002). Econometric Analysis of Cross Section and Panel Data. Cambridge, Massachusetts, London, England: The MIT Press.

148.WTSKlient.hu. (2017). Az adózók minösitése. Forrás: https://wtsklient.hu/2017/02/24/adozokminositese/

149.Zidková, H. (2014). Determinants of VAT gap in EU. Prague Economic Papers 4, 514-530. 


\section{Publikációk jegyzéke}

\section{A témakörrel kapcsolatos saját (ill. társszerzős) publikációk jegyzéke}

\section{Folyóiratcikk}

1. Máténé Bella Klaudia - Ritzlné Kazimir Ildikó (2020): A gazdasági és a szabályozási környezet változásának hatása az áfaelkerülés 2006 és 2016 közötti alakulására Magyarországon STATISZTIKAI SZEMLE 98 : 2 pp. 107-132. , 26 p. (2020)

2. Ritzlné Kazimir Ildikó (2017): Az adóelkerülés elmélete KÖZ-GAZDASÁG $12: 4$ pp. 257-268. , 12 p. (2017)

3. Ritzlné Kazimir Ildikó (2014): The Estimation of Gross Value Added of Sole Proprietors for 2011 in Hungary STATISZTIKAI SZEMLE special number : 18 pp. 89-109. , 21 p. (2014)

4. Ritzlné Kazimir Ildikó (2013): Az egyéni vállalkozók hozzáadott értékének számítása STATISZTIKAI SZEMLE 91 : 7 pp. 691-717. , 27 p. (2013)

5. Murai Bálint - Ritzlné Kazimir Ildikó (2011): A nem megfigyelt gazdaság mérésének lehetőségei STATISZTIKAI SZEMLE 89 : 5 pp. 501-522. , 22 p. (2011)

\section{Konferenciakiadvány}

6. Ritzlné Kazimir Ildikó (2018): Is the Hungarian Non-Observed Economy Rooted in Socialism? In: IARIW 35th General Conference (2018) pp. 1-13. , 13 p.

7. Ritzlné Kazimir Ildikó (2013): The Undeclared Value Added Due to the Value Added Tax Evasion of Sole Proprietors In: International, Statistical Institute (szerk.) Proceedings of the 59th World Statistics Congress of the International Statistical Institute The Hague, Hollandia : International Statistical Institute, (2013) pp. 1-6. , 6 p.

8. Ildiko Ritzlné Kazimir - Gergely Horváth - Johanna Giczi (2012): Modeling tax evasion of the self-employed in Hungary In: SMTDA (szerk.) Proceeding, 2nd Stochastic Modeling Techniques and Data Analysis International Conference Chania, Görögország (2012) pp. 349-357. , 9 p.

\section{Egyéb publikációk jegyzéke}

9. Máténé Bella Klaudia - Ritzlné Kazimir Ildikó - Cseh Tímea (2021): Áfaalapú diffúziós index a konjunktúrakutatásban STATISZTIKAI SZEMLE 99: 3 pp. 207232. 26 p. (2021)

10. Máténé Bella Klaudia - Ritzlné Kazimir Ildikó (2020): A multinacionális nagyvállalatok stratégiai döntéseinek hatása a termelés oldali GDP alakulására STATISZTIKAI SZEMLE 98: 3 pp. 212-241. 30 p. (2020) 
11. Máténé Bella Klaudia - Ritzlné Kazimir Ildikó (2020): A magyarországi fogyasztás tartósság szerinti vizsgálata 2005 és 2019 között In: Temesi József (szerk.) XVI. Gazdaságmodellezési Szakértői Konferencia: Előadások Pécs, Magyarország: Gazdaságmodellezési Társaság, (2020) pp. 109-117. 9 p.

12. Ritzlné Kazimir Ildikó (2020): Végtelen álmok- egy játék, amely megváltoztatta az innovációt azáltal, hogy forradalmian új megoldásokat, új üzleti és gazdasági modelleket és egy teljesen új munkamódszert hozott létre KÖZ-GAZDASÁG 15: 2 pp. 76-79. 4 p. (2020)

13. Máté-Bella Klaudia - Ritzl-Kazimir Ildikó (2019): Analysis of the Hungarian insurance sector's gross value added from 2003 to 2017 HUNGARIAN STATISTICAL REVIEW: JOURNAL OF THE HUNGARIAN CENTRAL STATISTICAL OFFICE 2: 2 pp. 79-105. 27 p. (2019)

14. Máténé Bella, Klaudia - Pinkasz, András - Ritzlné Kazimir, Ildikó (2019): Analysis of the development of the Automotive Cluster and its Impact on Economic Growth in Central and Eastern Europe between 2013 and 2018 In: Experiences and Future Challenges in Measuring Income and Wealth in CIS Countries and Eastern Europe (2019) pp. 1-24. 24 p.

15. Máténé Bella Klaudia - Ritzlné Kazimir Ildikó - Sugár András (2019): A magyarországi konjunktúrakutatás rövid történeti áttekintése STATISZTIKAI SZEMLE 97: 6 pp. 521-545. 25 p. (2019)

16. Pinkasz András - Ritzlné Kazimir Ildikó (2019): Profiling of the Hungarian participation in the global automotive value chain In: Group of Experts on National Accounts: Measuring Global Production (2019) pp. 1-8. 8 p.

17. Ilona Cserháti - Tibor Keresztély - Ildikó Ritzlné Kazimir (2018): The recent role of government in decreasing "harmful inequality" In: "Better Statistics for Better Lives": Jointly organised with OECD (2018)

18. Ritzlné Kazimir Ildikó - Murai Bálint - Anwar Klára - Száraz Anikó - Salamon Anikó (2016): Analysis of Productivity Trends in 'Manufacture of Motor Vehicles' Industry in Hungary between 1995 and 2014 In: International, Association for Research in Income; Wealth (szerk.) IARIW 34th General Conference (2016) pp. 1-14. $14 \mathrm{p}$.

19. Ritzlné Kazimir Ildikó (2011): The economic processes and the migration In: Bexheti, Abdylmenaf; Hashrova, Albana; Kreso, Sead; Meyer, Dietmar; Wenzel, Heinz-Dieter (szerk.) Development and Economic Policy: Ninth European Doctoral Seminar (EDS) -- Seminar Volume Bamberg, Németország: J. Berg Verlag, (2011) pp. 353-365. 13 p.

20. Ritzlné Kazimir Ildikó (2009): The monopolistic competition in Walras-Leontiefmodel In: Meyer, Dietmar; Kola, Tonin; Kreso, Sead; Bexheti, Abdylmenaf; Wenzel, H -Dieter (szerk.) Government and Private Sector in Transition 
Economies: 8th European doctoral seminar Bamberg, Németország: J. Berg Verlag, (2009) pp. 93-114. 22 p.

21. Ritzlné Kazimir Ildikó (2008): The matrix multiplier in open economies In: Meyer, Dietmar; Haderi, Sulo; Kreso, Sead; Bexheti, Abdylmenaf; Wenzel, H -Dieter (szerk.) Transformation in the Light of Theory and Globalization: 7th European doctoral seminar Bamberg, Németország: J. Berg Verlag, (2008) pp. 31-42. 12 p.

22. Ritzlné Kazimir Ildikó (2007): The matrix-multiplier In: Meyer, Dietmar; Haderi, Sulo; Kreso, Sead; Wenzel, H -Dieter (szerk.) Economic structure and institutions: sixth European Doctoral Seminar (EDS) Bamberg, Németország: J. Berg Verlag, (2007) pp. 232-242. 11 p.

23. Ritzlné Kazimir Ildikó (2007): A demográfiai átmenet hatása a Magyarországon kialakult regionális különbségekre In: Iványi, M; Bancila, R (szerk.) Bridges in Danube Basin: 6th International Conference on Bridges across the Danube Budapest, Magyarország: Mủegyetemi Kiadó, (2007) pp. 126-133. 8 p.

24. Ritzlné Kazimir Ildikó (2006): The reasons for inequality between economies In: Meyer, Dietmar; Haderi, Sulo; Kreso, Sead; Nardini, Franco; Wenzel, H -Dieter (szerk.) Challenges to change - Middle and Eastern European countries in transition: Fifth European Doctoral Seminar (EDS) Bamberg, Németország: BERG-Verlag, (2006) pp. 107-117. 11 p.

25. Ritzlné Kazimir Ildikó (2006): A regionális különbségek és a népesség alakulásának kapcsolata In: Szentes, Balázs (szerk.) Tudás és versenyképesség pannon szemmel 1 -2. kötet: Pannon Gazdaságtudományi Konferencia Veszprém, Magyarország: Pannon Egyetemi Kiadó, (2006) pp. 179-183. 5 p.

26. Ritzlné Kazimir Ildikó (2005): Néhány decentralizált mechanizmus összehasonlítása a kísérleti közgazdaságtan eszközeivel In: Dobricza, Anikó; Lados, Mihály; Limpók, Valéria; Takács, Dávid - Solt, Katalin (szerk.) Kísérleti közgazdaságtan Győr, Magyarország: Széchenyi István Egyetem, Gazdaság- és Társadalomtudományi Intézet, (2005) pp. 9-29. 21 p.

27. Ritzlné Kazimir Ildikó (2005): Közösségi javak - néhány decentralizált mechanizmus összehasonlítása a kísérleti közgazdaságtan eszközeivel TUDOMÁNYOS FÜZETEK 8: 1 pp. 9-29. 21 p. (2005)

28. Ritzlné Kazimir Ildikó (2004): A kísérleti közgazdaságtan főbb irányzatai és eredményei összehasonlítása pp. 106-115. 10 p. In: Majoros, Pál (szerk.) Tudástranszfer és információs társadalom Budapest, Magyarország: Budapesti Gazdasági Főiskola, (2004) 
Függelékek 


\section{1. függelék}

A felhasználás tábla leegyszerüsitett szerkezete

\begin{tabular}{|c|c|c|c|c|c|c|c|c|}
\hline & $\begin{array}{l}\text { Folyó termelöfelhasználás } \\
\text { NACE bontásban (59 ágazat) }\end{array}$ & $\begin{array}{l}\text { Háztartások } \\
\text { végső } \\
\text { fogyasztása }\end{array}$ & $\begin{array}{l}\text { Háztartásokat } \\
\text { segítő nonprofit } \\
\text { szervezetek végső } \\
\text { fogyasztása }\end{array}$ & $\begin{array}{l}\text { Kormányzat } \\
\text { végső } \\
\text { fogyasztása }\end{array}$ & $\begin{array}{l}\text { Bruttó állóeszköz- } \\
\text { felhalmozás }\end{array}$ & $\begin{array}{l}\text { Készlet- } \\
\text { változás }\end{array}$ & Export & $\begin{array}{l}\text { Felhasználás } \\
\text { összesen }\end{array}$ \\
\hline 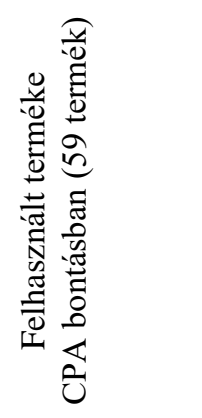 & & & & & & & & \\
\hline $\begin{array}{l}\text { Felhasználás } \\
\text { összesen }\end{array}$ & & & & & & & & \\
\hline
\end{tabular}


2. függelék: Az áfa fizetést befolyásoló fontosabb intézkedések kronologikus sorrendben

\begin{tabular}{|c|c|}
\hline Év & \\
\hline 2009 & ius 1 -jétől $25,18,5$ és $0 \%$ adókulcsok a korábbi $20,5,0 \%$ helyett. \\
\hline 2010 & litozások a szolgáltatások nyújtása esetében a teljesítés helyének megh \\
\hline 2011 & $\begin{array}{l}\text { Január 1. bővült a hulladéknak minősülö és emiatt fordított adózás alá eső termékek köre } \\
\text { A széndioxid kvóta értékesítése is a fordított adózás alá esik. }\end{array}$ \\
\hline 2012 & $\begin{array}{l}\text { Január } 1 \text {-jétől a } 25 \%-0 s \text { áfakulcs } 27 \% \text {-ra emelése } \\
\text { Láncügyletek szigorítása } \\
\text { Július } 1 \text {-jétől fordított adózás a mezőgazdaságban: gabona és olajos magvak } \\
\text { Közösségi ügyletben részt vevő adóalanyoknak összesítő nyilatkozatot kell benyújtaniuk }\end{array}$ \\
\hline 2013 & $\begin{array}{l}\text { Január 1-től az alanyi adómentesség alsó határa } 5 \text { millió Ft helyett } 6 \text { millió Ft } \\
\text { Belföldi tételes összesítö jelentés bevezetése (ahol az áthárított adó összege eléri vagy } \\
\text { meghaladja a } 2 \text { millió Ft-ot). } \\
\text { Fordított adózás alá eső termékek: élő sertés, vágott sertés, egyes takarmányok }\end{array}$ \\
\hline 2014 & $\begin{array}{l}\text { Január 1-töl 5\%-os adómérték alá tartozik az élösertés továbbá az egész és félsertés termékek } \\
\text { Fordított adózás változása az építőiparban (olyan tevékenységeknél is alkalmazni kell, } \\
\text { amelyek nem engedélykötelesek, hanem bejelentési kötelezettséggel járnak csak) } \\
\text { Online pénztárgépek bevezetése 2014. szeptember } \mathbf{1} \text {. }\end{array}$ \\
\hline 2015 & $\begin{array}{l}\text { Távolról nyújtható szolgáltatások esetében a szolgáltatás teljesítési helye is az igénybevevő } \\
\text { letelepedési helye } \\
\text { Moss bevezetése } \\
\text { Szerencsejáték szervezés koncesszió alá helyezése } \\
\text { Fordított adózás kiterjesztése a munkaerő kölcsönzésre } \\
5 \% \text {-os adókulcs alá eső termékek körének kibővítése (szarvasmarha, juh, kecske) } \\
\text { Belföldi összesítő nyilatkozatban az értékhatár 1millió Ft-ra csökkentése } \\
\text { Élelmiszer értékesítést végző automaták bejelentése } \\
\text { EKÁER bevezetése }\end{array}$ \\
\hline 2016 & $\begin{array}{l}\text { - } \quad \text { kockázatosnak minősített adózók esetén a visszaigénylés határideje legalább } 75 \text { nap } \\
\text { - } \quad \text { új lakás áfája 5\%-ra csökken } \\
\text { - } \quad \text { Sertéshús értékesítés áfája 5\% }\end{array}$ \\
\hline 2017 & $\begin{array}{l}\text { Január 1-jétől online pénztárgép köteles tevékenységek: } \\
\text { - gépjárműjavítás, } \\
\text { - pénzváltás, } \\
\text { - plasztikai sebészet, } \\
\text { - gépjármü alkatrész kiskereskedelem, } \\
\text { - motorkerékpár alkatrész kiskereskedelem, javítás, } \\
\text { - taxis személyszállítás, } \\
\text { - fitness és testépítő klubok, tánctermi diszkó müködtetés, } \\
\text { - textil tisztítás, vasalás, } \\
\text { - fizikai közérzetet javító szolgáltatások (szolárium, masszázs szalon, fürdők, szauna, } \\
\text { gyógyfürdő). } \\
\text { Január 1-jétől 5\% a baromfi termékek és tojás ÁFA-ja } \\
\text { Július 1-től csökkentették a belföldi összesítő nyilatkozat értékhatárát } 100 \text { ezer Ft-ra } \\
\text { Megbízható adózók esetében a visszaigénylések határideje } 45 \text { napra csökken. }\end{array}$ \\
\hline 2018 & $\begin{array}{l}\text { Július 1-től az online számla küldés bevezetése } \\
\text { Megbízható adózók esetében a visszaigénylések határideje } 30 \text { napra csökken (Nyrt esetében } \\
20 \text { nap). (2017. évi CL. Tv. } 154 \S(3),(4))\end{array}$ \\
\hline 2019 & Január 1-jétől UHT és ESL tej áfa-ja 5\%-ra csökken \\
\hline
\end{tabular}




\section{3. függelék: A Kolmogorov-Smirnov teszt eredménye a vizsgálatba bevont változókra}

\begin{tabular}{|c|c|c|}
\hline Változó neve & D érték & p érték \\
\hline Anyagköltség aránya az igénybe vett szolgáltatások és egyéb szolgáltatások összegéhez & 0.413564 & $<0.0100$ \\
\hline Bruttó hozzáadott érték aránya a kibocsátáshoz & 0.463368 & $<0.0100$ \\
\hline Anyagköltség aránya a kibocsátáshoz & 0.472311 & $<0.0100$ \\
\hline Személyi kifizetések aránya a kibocsátáshoz & 0.468024 & $<0.0100$ \\
\hline Anyagköltség aránya a bevételhez & 0.322447 & $<0.0100$ \\
\hline Személyi kifizetések aránya a bruttó hozzáadott értékhez & 0.459235 & $<0.0100$ \\
\hline Közvetített szolgáltatások aránya az összes bevételhez & 0.419378 & $<0.0100$ \\
\hline Eladott áruk beszerzési értékének aránya az összes bevételhez & 0.358732 & $<0.0100$ \\
\hline Értékesítés aránya a beszerzéshez & 0.495507 & $<0.0100$ \\
\hline Értékesítés aránya a fizetendő áfa alapjához & 0.382143 & $<0.0100$ \\
\hline Beszerzés aránya az előzetesen felszámított ÁFA alapjához & 0.16955 & $<0.0100$ \\
\hline $\begin{array}{l}\text { Tárgyidőszakra jutó ÁFA aránya a fizetendő ÁFA és előzetes ÁFA alapjának a } \\
\text { különbségéhez }\end{array}$ & 0.501194 & $<0.0100$ \\
\hline Export aránya az értékesítéshez & 0.478812 & $<0.0100$ \\
\hline Import aránya a beszerzéshez & 0.453479 & $<0.0100$ \\
\hline Egy före jutó bruttó hozzáadott érték & 0.455022 & $<0.0100$ \\
\hline Egy főre jutó személyi kifizetés & 0.285471 & $<0.0100$ \\
\hline Eltitkolt ÁFA & 0.487293 & $<0.0100$ \\
\hline Létszám & 0.472513 & $<0.0100$ \\
\hline Bevétel & 0.484517 & $<0.0100$ \\
\hline Közvetített szolgáltatás & 0.478528 & $<0.0100$ \\
\hline ELÁBÉ & 0.49063 & $<0.0100$ \\
\hline Aktivált saját teljesítmények értéke & 0.478305 & $<0.0100$ \\
\hline Anyagköltség & 0.488782 & $<0.0100$ \\
\hline Igénybevett szolgáltatások & 0.484806 & $<0.0100$ \\
\hline Egyéb szolgáltatások & 0.486533 & $<0.0100$ \\
\hline Személyi kifizetések & 0.479117 & $<0.0100$ \\
\hline Kibocsátás & 0.481834 & $<0.0100$ \\
\hline Folyó termelőfelhasználás & 0.485666 & $<0.0100$ \\
\hline Bruttó hozzáadott érték & 0.475432 & $<0.0100$ \\
\hline Profit & 0.475713 & $<0.0100$ \\
\hline Értékesítés & 0.477018 & $<0.0100$ \\
\hline Beszerzés & 0.479378 & $<0.0100$ \\
\hline Export & 0.490625 & $<0.0100$ \\
\hline Import & 0.490788 & $<0.0100$ \\
\hline Tárgyidőszakra jutó ÁFA & 0.456082 & $<0.0100$ \\
\hline Előzetesen felszámított ÁFA & 0.479464 & $<0.0100$ \\
\hline Fizetendő ÁFA & 0.480558 & $<0.0100$ \\
\hline
\end{tabular}




\begin{tabular}{|c|c|c|c|c|c|c|c|c|c|c|}
\hline & 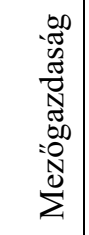 & $\stackrel{\Xi}{\Xi}$ & 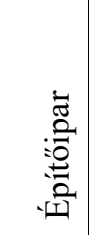 & 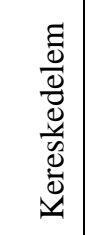 & 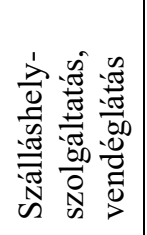 & 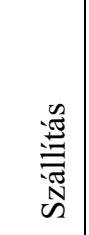 & $\begin{array}{l}\overrightarrow{b D} \\
: \vec{N} \\
\overrightarrow{0} \\
0\end{array}$ & 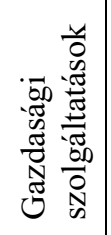 & 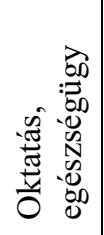 & 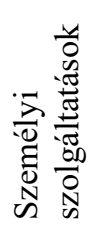 \\
\hline Faktorok száma & 8 & 6 & 6 & 6 & 6 & 6 & 6 & 2 & 6 & 6 \\
\hline Tárgyidőszakra jutó ÁFA & 0.64 & 0.76 & 0.89 & 0.65 & 0.85 & 0.84 & 0.76 & & 0.83 & 0.86 \\
\hline Anyagköltség & 0.85 & 0.97 & 0.94 & 0.39 & 0.76 & & 0.95 & & 0.93 & 0.88 \\
\hline Aktivált saját teljesítmények értéke & 0.53 & 0.62 & & 0.05 & 0.52 & & & & & \\
\hline Beszerzés & 0.96 & 0.97 & 0.98 & 0.98 & 0.92 & 0.91 & 0.94 & 0.94 & 0.93 & 0.95 \\
\hline Bevétel & 0.99 & 0.98 & 0.99 & 0.98 & 0.99 & 0.97 & 0.99 & & 0.99 & 0.96 \\
\hline Egyéb szolgáltatások & 0.45 & 0.19 & 0.83 & 0.14 & 0.70 & 0.90 & 0.44 & 0.51 & 0.73 & 0.76 \\
\hline ELÁBÉ & 0.95 & 0.37 & 0.80 & 0.97 & & & 0.87 & & 0.95 & 0.46 \\
\hline Előzetesen felszámított áfa & 0.96 & 0.97 & 0.98 & 0.98 & 0.92 & 0.92 & 0.94 & 0.94 & 0.93 & 0.95 \\
\hline Értékesítés & 0.97 & 0.97 & 0.99 & 0.98 & 0.99 & 0.97 & 0.94 & & 0.95 & 0.98 \\
\hline Export & 0.91 & 0.95 & 0.52 & 0.51 & 0.87 & 0.52 & 0.12 & & 0.95 & 0.76 \\
\hline Fizetendő áfa & 0.98 & 0.99 & 0.99 & 0.99 & 0.98 & 0.98 & 0.94 & & 0.96 & 0.98 \\
\hline Bruttó hozzáadott érték & 0.90 & 0.86 & 0.78 & 0.86 & 0.97 & & 0.99 & & & \\
\hline Folyó termelőfelhasználás & 0.94 & 0.97 & 0.97 & 0.93 & 0.94 & 0.93 & 0.96 & 0.89 & 0.97 & 0.90 \\
\hline Igénybevett szolgáltatások & 0.74 & 0.69 & 0.86 & 0.93 & 0.90 & 0.88 & 0.94 & 0.77 & 0.91 & 0.81 \\
\hline Import & 0.93 & 0.97 & 0.88 & 0.91 & 0.75 & 0.76 & 0.51 & & 0.96 & 0.73 \\
\hline Közvetített szolgáltatás & 0.65 & 0.45 & 0.89 & & 0.66 & 0.87 & & & 0.81 & 0.68 \\
\hline Létszám & 0.90 & 0.70 & 0.84 & 0.72 & 0.90 & 0.91 & 0.63 & & 0.93 & 0.92 \\
\hline $\begin{array}{l}\text { Anyagköltség aránya az igénybe vett } \\
\text { és egyéb szolgáltatások összegéhez }\end{array}$ & 0.83 & 0.67 & & 0.79 & & 0.56 & 0.97 & & & 0.66 \\
\hline $\begin{array}{l}\text { Bruttó hozzáadott érték aránya a } \\
\text { kibocsátáshoz }\end{array}$ & 0.99 & 0.93 & & 0.71 & & 0.67 & & & 0.48 & 0.46 \\
\hline Anyagköltség aránya a kibocsátáshoz & 0.99 & 0.69 & & 0.87 & & & 0.99 & & & 0.90 \\
\hline $\begin{array}{l}\text { Személyi kifizetések aránya a } \\
\text { kibocsátáshoz }\end{array}$ & 0.98 & 0.80 & 0.45 & 0.69 & 0.09 & 0.56 & & & & \\
\hline Anyagköltség aránya a bevételhez & 0.80 & 0.69 & 0.47 & 0.78 & & & 0.36 & & & 0.82 \\
\hline $\begin{array}{l}\text { Személyi kifizetések aránya a bruttó } \\
\text { hozzáadott értékhez }\end{array}$ & 0.99 & 0.06 & 0.16 & 0.00 & 0.16 & 0.01 & & & & \\
\hline $\begin{array}{l}\text { Közvetített szolgáltatások aránya az } \\
\text { összes bevételhez }\end{array}$ & 0.67 & 0.53 & 0.53 & 0.07 & 0.72 & 0.62 & & & & 0.35 \\
\hline $\begin{array}{l}\text { Eladott áruk beszerzési értékének } \\
\text { aránya az összes bevételhez }\end{array}$ & & & 0.17 & 0.62 & 0.53 & 0.51 & & & 0.42 & \\
\hline Értékesítés aránya a beszerzéshez & & 0.04 & & 0.00 & 0.39 & 0.17 & 0.40 & & 0.56 & 0.74 \\
\hline $\begin{array}{l}\text { Értékesítés aránya a fizetendő áfa } \\
\text { alapjához }\end{array}$ & 0.81 & & & 0.54 & 0.88 & & & & 0.73 & 0.77 \\
\hline $\begin{array}{l}\text { Beszerzés aránya az előzetesen } \\
\text { felszámított ÁFA alapjához }\end{array}$ & 0.70 & 0.56 & 0.30 & 0.67 & 0.82 & 0.62 & 0.36 & 0.04 & 0.69 & 0.74 \\
\hline Export aránya az értékesítéshez & 0.76 & 0.50 & 0.64 & 0.06 & 0.86 & 0.41 & 0.14 & & 0.94 & 0.64 \\
\hline Import aránya a beszerzéshez & 0.73 & 0.53 & 0.37 & 0.29 & 0.56 & 0.39 & 0.72 & & 0.56 & 0.59 \\
\hline Egy före jutó bruttó hozzáadott érték & & 0.75 & 0.51 & 0.13 & 0.57 & 0.60 & & & 0.58 & \\
\hline Egy före jutó személyi kifizetés & 0.54 & 0.60 & 0.66 & 0.53 & 0.54 & 0.61 & 0.94 & & 0.44 & 0.43 \\
\hline Kibocsátás & 0.99 & 0.98 & 0.97 & 0.93 & 0.99 & 0.97 & 0.99 & & 0.99 & 0.96 \\
\hline Profit & 0.91 & 0.89 & 0.90 & 0.94 & 0.98 & & 0.99 & & & 0.94 \\
\hline Személyi kifizetések & 0.91 & 0.86 & 0.94 & 0.86 & 0.98 & 0.95 & 0.93 & & 0.97 & 0.85 \\
\hline
\end{tabular}


5. függelék: Az outlierszüréshez alkalmazott faktorok száma és a változók kommunalitása, 2012.

\begin{tabular}{|c|c|c|c|c|c|c|c|c|c|c|c|c|}
\hline & 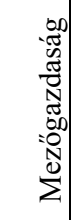 & 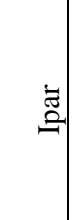 & 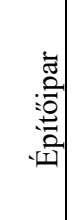 & 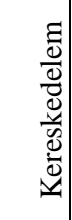 & : & 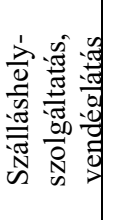 & 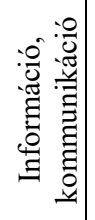 & 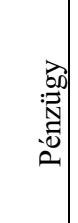 & 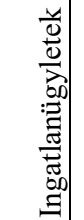 & 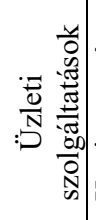 & 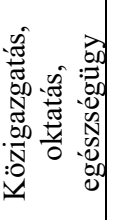 & 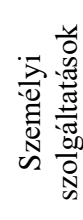 \\
\hline Faktorok száma & 6 & 6 & 6 & 6 & 6 & 6 & 6 & 2 & 6 & 6 & 6 & 6 \\
\hline Tárgyidőszakra jutó ÁFA & 0.89 & 0.95 & 0.84 & 0.62 & 0.90 & 0.84 & 0.96 & & 0.71 & 0.60 & 0.71 & 0.58 \\
\hline Anyagköltség & 0.76 & 0.96 & 0.88 & 0.51 & 0.97 & & 0.93 & & 0.46 & 0.59 & 0.86 & 0.80 \\
\hline $\begin{array}{l}\text { Aktivált saját teljesítmények } \\
\text { értéke }\end{array}$ & 0.48 & 0.35 & & 0.05 & 0.80 & & 0.78 & & & & & 0.82 \\
\hline Beszerzés & 0.97 & 0.96 & 0.95 & 0.94 & 0.96 & 0.97 & 0.98 & 0.97 & 0.85 & 0.95 & 0.99 & 0.92 \\
\hline Bevétel & 0.96 & 0.98 & 0.98 & 0.90 & 0.97 & 0.99 & 0.99 & & 0.86 & 0.90 & & 0.99 \\
\hline Egyéb szolgáltatások & 0.43 & 0.96 & 0.69 & 0.82 & 0.90 & 0.71 & 0.95 & 0.71 & 0.37 & 0.18 & & 0.97 \\
\hline ELÁBÉ & 0.64 & 0.79 & 0.65 & 0.85 & & 0.97 & 0.78 & & 0.81 & 0.82 & & \\
\hline Elözetesen felszámított áfa & 0.97 & 0.96 & 0.95 & 0.95 & 0.63 & 0.99 & 0.98 & 0.97 & 0.86 & 0.95 & 0.99 & 0.92 \\
\hline Értékesítés & 0.97 & 0.99 & 0.96 & 0.97 & 0.98 & 0.78 & 0.97 & & 0.66 & 0.81 & & 0.99 \\
\hline Export & 0.69 & 0.94 & 0.69 & 0.66 & 0.94 & 0.99 & 0.72 & & 0.49 & 0.53 & & 0.80 \\
\hline Fizetendő áfa & 0.98 & 0.98 & 0.95 & 0.98 & 0.97 & 0.92 & 0.99 & & 0.78 & 0.89 & & 0.99 \\
\hline Bruttó hozzáadott érték & 0.92 & 0.94 & 0.93 & 0.83 & 0.89 & & 0.95 & & & & 0.92 & \\
\hline Folyó termelőfelhasználás & 0.87 & 0.97 & 0.90 & 0.84 & 0.99 & 0.88 & 0.97 & 0.96 & 0.81 & 0.82 & & 1.00 \\
\hline Igénybevett szolgáltatások & 0.85 & 0.81 & 0.68 & 0.86 & 0.98 & 0.81 & 0.93 & 0.92 & 0.56 & 0.65 & & 0.99 \\
\hline Import & 0.54 & 0.93 & 0.70 & 0.72 & 0.86 & 0.67 & 0.86 & & 0.60 & 0.87 & & 0.87 \\
\hline Közvetített szolgáltatás & 0.88 & 0.59 & 0.82 & & 0.52 & 0.92 & 0.92 & & 0.26 & 0.69 & & \\
\hline Létszám & 0.80 & 0.76 & 0.91 & 0.83 & 0.93 & 0.48 & 0.88 & & 0.73 & 0.76 & & 0.99 \\
\hline $\begin{array}{l}\text { Anyagköltség aránya az igénybe } \\
\text { vett és egyéb szolgáltatások } \\
\text { összegéhez }\end{array}$ & 0.66 & 0.70 & & 0.81 & & 0.97 & 0.75 & & & 0.51 & 0.87 & \\
\hline $\begin{array}{l}\text { Bruttó hozzáadott érték aránya a } \\
\text { kibocsátáshoz }\end{array}$ & 0.82 & 0.51 & & 0.97 & & 0.97 & 0.76 & & 0.07 & 0.90 & 0.91 & 0.82 \\
\hline $\begin{array}{l}\text { Anyagköltség aránya a } \\
\text { kibocsátáshoz }\end{array}$ & 0.83 & 0.68 & & 0.88 & & & & & & 0.92 & 0.96 & \\
\hline $\begin{array}{l}\text { Személyi kifizetések aránya a } \\
\text { kibocsátáshoz }\end{array}$ & 0.41 & 0.57 & 0.19 & 0.96 & 0.71 & 0.05 & & & & & & 0.85 \\
\hline Anyagköltség aránya a bevételhez & 0.71 & 0.71 & 0.49 & 0.81 & & & 0.82 & & & 0.44 & 0.98 & \\
\hline $\begin{array}{l}\text { Személyi kifizetések aránya a } \\
\text { bruttó hozzáadott értékhez }\end{array}$ & 0.00 & 0.02 & 0.09 & 0.00 & 0.70 & 0.90 & & & & & & \\
\hline $\begin{array}{l}\text { Közvetített szolgáltatások aránya } \\
\text { az összes bevételhez }\end{array}$ & 0.07 & 0.50 & 0.40 & 0.03 & 0.37 & 0.50 & & & & 0.39 & & \\
\hline $\begin{array}{l}\text { Eladott áruk beszerzési értékének } \\
\text { aránya a bevételhez }\end{array}$ & & & 0.78 & 0.63 & 0.11 & 0.65 & & & 0.38 & & & \\
\hline Értékesítés aránya a beszerzéshez & & 0.02 & & 0.00 & 0.17 & 0.70 & 0.97 & & 0.48 & 0.05 & 0.70 & 0.44 \\
\hline $\begin{array}{l}\text { Értékesítés aránya a fizetendő áfa } \\
\text { alapjához }\end{array}$ & 0.49 & & & 0.60 & 0.01 & & & & 0.63 & 0.69 & & \\
\hline $\begin{array}{l}\text { Beszerzés aránya az előzetesen } \\
\text { felszámított ÁFA alapjához }\end{array}$ & 0.56 & 0.65 & 0.70 & 0.77 & 0.64 & 0.62 & 0.76 & 0.09 & 0.66 & 0.73 & 0.66 & 0.70 \\
\hline $\begin{array}{l}\text { Tárgyidőszakra jutó ÁFA aránya a } \\
\text { fizetendő ÁFA és előzetes ÁFA } \\
\text { alapjának a különbségéhez }\end{array}$ & & 0.00 & & 0.00 & 0.00 & & & & & & & \\
\hline Export aránya az értékesítéshez & 0.67 & 0.54 & 0.49 & 0.31 & 0.26 & 0.50 & 0.72 & & 0.35 & 0.20 & & 0.77 \\
\hline Import aránya a beszerzéshez & 0.70 & 0.56 & 0.55 & 0.26 & 0.41 & 0.36 & 0.65 & & 0.67 & 0.20 & & 0.42 \\
\hline $\begin{array}{l}\text { Egy före jutó bruttó hozzáadott } \\
\text { érték }\end{array}$ & & 0.28 & 0.14 & 0.15 & 0.64 & 0.71 & & & 0.62 & & 0.65 & \\
\hline Egy főre jutó személyi kifizetés & 0.55 & 0.67 & 0.66 & 0.51 & 0.59 & 0.97 & 0.73 & & 0.50 & 0.43 & & 0.76 \\
\hline Kibocsátás & 0.94 & 0.99 & 0.93 & 0.97 & 0.98 & 0.95 & 0.97 & & 0.89 & 0.90 & 0.97 & 0.99 \\
\hline Profit & 0.95 & 0.94 & 0.97 & 0.92 & 0.97 & & 0.97 & & & 0.91 & 0.95 & \\
\hline Személyi kifizetések & 0.92 & 0.85 & 0.92 & 0.87 & 0.94 & & 0.90 & & 0.82 & 0.92 & & 1.00 \\
\hline
\end{tabular}


6. függelék: Az outlierszüréshez alkalmazott faktorok száma és a változók kommunalitása, 2016.

\begin{tabular}{|c|c|c|c|c|c|c|c|c|c|c|c|}
\hline & 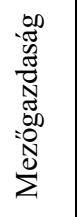 & $\stackrel{\check{\tilde{z}}}{\varrho}$ & 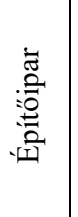 & 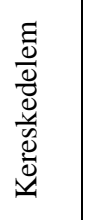 & 吢 & 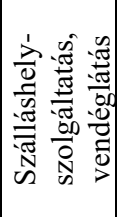 & 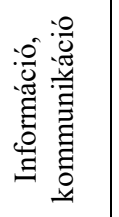 & 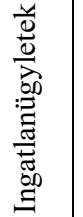 & 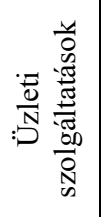 & 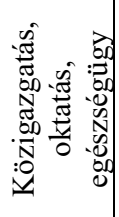 & 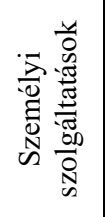 \\
\hline Faktorok száma & 6 & 6 & 6 & 6 & 6 & 6 & 6 & 6 & 6 & 6 & 6 \\
\hline Tárgyidőszakra jutó ÁFA & 0.66 & 0.91 & 0.88 & 0.69 & 0.90 & 0.97 & 0.92 & 0.77 & 0.84 & 0.994 & 0.99 \\
\hline Anyagköltség & 0.90 & 0.99 & 0.87 & 0.63 & 0.80 & & 0.89 & 0.89 & 0.51 & 0.994 & 0.84 \\
\hline Aktivált saját teljesítmények értéke & 0.95 & 0.69 & & 0.37 & 0.47 & & 0.77 & & & & 0.49 \\
\hline Beszerzés & 0.97 & 0.92 & 0.96 & 0.93 & 0.96 & 0.99 & 0.97 & 0.92 & 0.92 & 0.995 & 0.99 \\
\hline Bevétel & 1.00 & 0.99 & 0.97 & 0.86 & 0.99 & 0.99 & 0.96 & 0.94 & 0.97 & & 0.98 \\
\hline Egyéb szolgáltatások & 0.74 & 0.43 & 0.66 & 0.84 & 0.94 & 0.50 & 0.90 & 0.50 & 0.81 & 0.995 & 0.93 \\
\hline ELÁBÉ & 0.75 & 0.79 & 0.73 & 0.84 & & & 0.35 & 0.23 & 0.70 & & \\
\hline Előzetesen felszámított áfa & 0.98 & 0.92 & 0.96 & 0.93 & 0.96 & 0.99 & 0.97 & 0.92 & 0.92 & & 0.99 \\
\hline Értékesítés & 0.99 & 0.99 & 0.93 & 0.94 & 0.92 & 0.99 & 0.95 & 0.85 & 0.97 & & 0.98 \\
\hline Export & 0.91 & 0.84 & 0.76 & 0.43 & 0.93 & 0.91 & 0.57 & 0.90 & 0.74 & & 0.90 \\
\hline Fizetendő áfa & 1.00 & 0.99 & 0.96 & 0.95 & 0.96 & 0.98 & 0.97 & 0.83 & 0.96 & & 1.00 \\
\hline Bruttó hozzáadott érték & 0.95 & 0.93 & 0.87 & 0.93 & 0.98 & & 0.98 & & & 0.996 & \\
\hline Folyó termelőfelhasználás & 0.97 & 0.99 & 0.90 & 0.89 & 0.97 & 0.99 & 0.97 & 0.84 & 0.79 & & 0.99 \\
\hline Igénybevett szolgáltatások & 0.92 & 0.90 & 0.64 & 0.84 & 0.97 & 0.98 & 0.97 & 0.74 & 0.80 & & 0.99 \\
\hline Import & 0.92 & 0.94 & 0.87 & 0.67 & 0.80 & 0.93 & 0.88 & 0.61 & 0.77 & & 0.99 \\
\hline Közvetített szolgáltatás & 0.68 & 0.60 & 0.85 & & 0.73 & 0.74 & 0.50 & 0.58 & 0.83 & & \\
\hline Létszám & 0.92 & 0.91 & 0.73 & 0.89 & 0.88 & 0.83 & 0.96 & 0.91 & 0.60 & & 0.68 \\
\hline $\begin{array}{l}\text { Anyagköltség aránya az igénybe } \\
\text { vett és egyéb szolgáltatások } \\
\text { összegéhez }\end{array}$ & 0.55 & 0.61 & & 0.51 & & 0.43 & 0.73 & & 0.25 & 0.785 & 0.58 \\
\hline $\begin{array}{l}\text { Bruttó hozzáadott érték aránya a } \\
\text { kibocsátáshoz }\end{array}$ & 0.75 & 0.89 & & 0.85 & & 0.64 & & 0.12 & 0.50 & 0.969 & \\
\hline $\begin{array}{l}\text { Anyagköltség aránya a } \\
\text { kibocsátáshoz }\end{array}$ & 0.91 & 0.66 & & 0.72 & & & 0.75 & & 0.91 & 0.954 & \\
\hline $\begin{array}{l}\text { Személyi kifizetések aránya a } \\
\text { kibocsátáshoz }\end{array}$ & 0.75 & 0.78 & 0.91 & 0.24 & 0.12 & 0.75 & & & & & 0.77 \\
\hline Anyagköltség aránya a bevételhez & 0.85 & 0.41 & 0.50 & 0.62 & & & 0.54 & & 0.91 & 0.975 & \\
\hline $\begin{array}{l}\text { Személyi kifizetések aránya a bruttó } \\
\text { hozzáadott értékhez }\end{array}$ & 0.05 & 0.04 & 0.90 & 0.01 & 0.26 & 0.21 & & & & & \\
\hline $\begin{array}{l}\text { Közvetített szolgáltatások aránya az } \\
\text { összes bevételhez }\end{array}$ & 0.31 & 0.72 & 0.06 & 0.04 & 0.45 & 0.87 & & & 0.31 & & \\
\hline $\begin{array}{l}\text { Eladott áruk beszerzési értékének } \\
\text { aránya az összes bevételhez }\end{array}$ & & & 0.54 & 0.46 & 0.70 & 0.31 & & 0.15 & & 0.964 & 0.91 \\
\hline Értékesítés aránya a beszerzéshez & & 0.04 & & 0.01 & 0.54 & 0.29 & 0.09 & 0.56 & 0.21 & & \\
\hline $\begin{array}{l}\text { Értékesítés aránya a fizetendő áfa } \\
\text { alapjához }\end{array}$ & 0.71 & & & 0.72 & 0.78 & & & 0.69 & 0.76 & & \\
\hline \begin{tabular}{|l|} 
Beszerzés aránya az előzetesen \\
felszámított ÁFA alapjához
\end{tabular} & 0.65 & 0.60 & 0.48 & 0.75 & 0.82 & 0.68 & 0.69 & 0.59 & 0.73 & 0.999 & 0.71 \\
\hline $\begin{array}{l}\text { Tárgyidőszakra jutó ÁFA aránya a } \\
\text { fizetendő ÁFA és előzetes ÁFA } \\
\text { alapjának a különbségéhez }\end{array}$ & & 0.00 & & 0.00 & 0.00 & & & & & & \\
\hline Export aránya az értékesítéshez & 0.70 & 0.63 & 0.45 & 0.43 & 0.53 & 0.64 & 0.71 & 0.64 & 0.56 & & 0.89 \\
\hline Import aránya a beszerzéshez & 0.70 & 0.67 & 0.35 & 0.31 & 0.66 & 0.39 & 0.62 & 0.46 & 0.47 & & 0.55 \\
\hline $\begin{array}{l}\text { Egy före jutó bruttó hozzáadott } \\
\text { érték }\end{array}$ & & 0.81 & 0.68 & 0.20 & 0.53 & 0.89 & & 0.71 & & 0.981 & \\
\hline Egy före jutó személyi kifizetés & 0.48 & 0.63 & 0.65 & 0.54 & 0.62 & 0.64 & 0.75 & 0.39 & 0.40 & & 0.78 \\
\hline Kibocsátás & 0.99 & 0.99 & 0.96 & 0.98 & 0.99 & 0.99 & 0.99 & 0.95 & 0.97 & 0.995 & 0.98 \\
\hline Profit & 0.95 & 0.95 & 0.91 & 0.96 & 0.98 & & 0.99 & & 0.95 & 0.996 & \\
\hline Személyi kifizetések & 0.92 & 0.96 & 0.83 & 0.95 & 0.98 & 0.97 & 0.99 & 0.93 & 0.94 & & 0.94 \\
\hline
\end{tabular}


